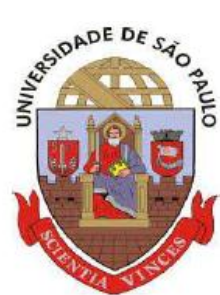

Universidade de São Paulo

Faculdade de Filosofia, Letras e Ciências Humanas

Universidade do Estado do Amazonas

Programa de Pós-Graduação em Geografia Humana

(Doutorado Interinstitucional - USP/UEA)

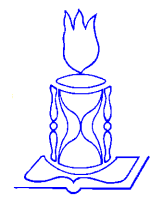

FFLCH

A PRODUÇÃO E A PERCEPÇÃO DO TURISMO EM PARINTINS, AMAZONAS

VERSÃO CORRIGIDA

São Paulo

2013 


\title{
A PRODUÇÃO E A PERCEPÇÃO DO TURISMO EM PARINTINS, AMAZONAS
}

\author{
VERSÃO CORRIGIDA \\ De Acordo:
}

Dr. Marcello Martinelli

\begin{abstract}
Tese apresentada ao Programa de Pós-Graduação em Geografia Humana, da Universidade de São Paulo para a obtenção do título de Doutor em Ciências.
\end{abstract}

Área de Concentração: Geografia Humana

Orientador: Dr. Marcello Martinelli

São Paulo 
Autorizo a reprodução e divulgação total ou parcial deste trabalho, por qualquer meio convencional ou eletrônico, para fins de estudo ou pesquisa, desde que citada a fonte.

Catalogação na Publicação

Serviço de Biblioteca e Documentação

Faculdade de Filosofia, Letras e Ciências Humanas da Universidade de São Paulo

AZEVEDO FILHO, JOÃO D'ANUZIO MENEZES DE

A993p A PRODUÇÃO E A PERCEPÇÃO DO TURISMO EM PARINTINS,

AMAZONAS / JOÃO D'ANUZIO MENEZES DE AZEVEDO FILHO; orientador MARCELLO MARTINELLI. - São Paulo, 2013.

$210 \mathrm{f}$.

Tese (Doutorado)- Faculdade de Filosofia, Letras e Ciências Humanas da Universidade de São Paulo.

Departamento de Geografia. Área de concentração:

Geografia Humana.

1. Amazônia. 2. Comunidades. 3. Turismo. 4.

Folclore. 5. Espaço. I. MARTINELLI, MARCELLO, orient. II. Título.

Apoio institucional: 
JOÃO D’ANUZIO MENEZES DE AZEVEDO FILHO

A PRODUÇÃO E A PERCEPÇÃO DO TURISMO EM PARINTINS, AMAZONAS

Tese apresentada ao Programa de Pós-Graduação em Geografia Humana, da Universidade de São Paulo para a obtenção do título de Doutor em Ciências.

Aprovada em: 06 / 08 / 2013

Banca Examinadora

$1^{\circ}$ Membro: Dr. Marcello Martinelli (Orientador)

Instituição: FFLCH - USP Assinatura:

$2^{\circ}$ Membro: Wagner Costa Ribeiro

Instituição: FFLCH - USP Assinatura:

$3^{\circ}$ Membro: Luiz Gonzaga Godoi Trigo

Instituição: EACH - USP Assinatura:

$4^{\circ}$ Membro: Dra. Rita de Cássa Ariza da Cruz

Instituição: FFLCH - USP Assinatura:

$5^{\circ}$ Membro: Carlossandro Carvalho de Albuquerque

Instituição: UEA (externo) Assinatura: 
Dedico este trabalho a minha família: pais, irmãos, esposa, filhos e principalmente ao meu irmão Erivaldo (19682008), que se foi cedo para ficar mais perto de nós, e a minha avó Sebastiana (1916-2009) que viveu o tempo necessário para acompanhar as mudanças desse mundo e nos conceder seu exemplo de mulher guerreira. 


\section{Agradecimentos}

A Deus, pelo dom da vida que nos possibilita decidir pelos caminhos a serem trilhados.

Aos meus pais João e Iracy. Ele, homem trabalhador, ligado a terra e à labuta dura da vida; ela, companheira, mãe, educadora dos filhos, orientadora para a vida. Obrigado pelas oportunidades oferecidas com muito sacrifício, num tempo de muitas dificuldades. Extensivo a todos os meus irmãos que sempre acreditaram em mim e direcionaram suas preces para o meu sucesso: Manuel, Edevaldo, Iranilza, Erivaldo (in memoriam), Iraneide, Iranilce, Edney e Denise.

À minha família, pelo apoio, colaboração, renúncias, saudades e compreensão nos momentos decisivos. Filhos: Nicholas e Giovanna, e Rosinda, companheira de todos os momentos, que encontrou tempo em sua atribulada jornada de mãe trabalhadora para fazer a revisão ortográfica deste trabalho.

Ao D’Anuzio, filho mais velho, que estimulou e sempre que possível deu apoio em Manaus.

Aos colegas de trabalho que, nas situações em que minha ausência das atividades acadêmicas se fez necessária, não se recusaram a contribuir com mais horas de trabalho nas turmas por nós compartilhadas. A vocês: Alem, Bosco, Camilo, Charlene, Carmen, Reginaldo, Estevan e Tatiana, meu carinho e agradecimento.

Aos amigos de todas as horas, aqueles que sempre têm uma palavra para confortar, uma experiência a compartilhar, os mais diversos apoios a nos conceder, meus agradecimentos: Sidiney, Carlossandro, Ieda, Girão, Willer.

A todos os colegas e funcionários do Centro de Estudos Superiores de Parintins, da Universidade do Estado do Amazonas e ao Diretor David Xavier, pelo apoio e esforço na solução dos trâmites administrativos sempre que solicitado.

Aos colegas do Minter e Dinter, com os quais vivi esse tempo de sacrifício e doação, tempo em que encontramos uns nos outros apoio e companheirismo para os momentos de apreensão, dor e também de muitas alegrias: Camilo, Isaque, Cristiane, Marcos, Simone, Selma, Nazaré, Hudson e Nonata. 
Aos trabalhadores ribeirinhos da região: pescadores, agricultores e artesãos que dividem suas atividades tradicionais com a do turismo e que contribuíram, com sua experiência, para a realização deste trabalho, em especial D. Raquel, Afonso, João, Raimundo e tantos outros.

Aos agentes de turismo, empresários, coordenadores do turismo no município, secretários ligados ao turismo no município de Parintins pela colaboração: à Carla Garcia e Eduardo Gomes, da Coordenação de Turismo; Luana e Ângela, empresárias do turismo.

À administração superior da Universidade do Estado do Amazonas que propiciou o convênio de Doutorado Interinstitucional com a Universidade de São Paulo e que me possibilitou concluí-lo.

Aos professores da USP que colaboraram nesse projeto e nos abriram as portas da Cidade Universitária e de São Paulo, para vivenciá-las e assim vislumbrar novos horizontes para a pesquisa em Geografia, especialmente ao Hélvio, Rita de Cássia, Rosangela, Rosa Ester, Sandra e Wagner.

Ao meu orientador, professor Marcello Martinelli, pelas palavras de estímulo e compreensão e por tudo o que pude aprender com sua longa história na Geografia e na Cartografia.

À Fundação de Apoio à Pesquisa no Estado do Amazonas (FAPEAM), pela bolsa de doutorado do Programa RH-Interiozação, que contribui para que pessoas como eu, vindas das cidades do interior do Amazonas, possam fazer cursos de pós-graduação em qualquer parte do Brasil.

Enfim, a todos que de alguma forma contribuíram para a realização deste trabalho, meus sinceros agradecimentos. 
"Muere lentamente quien no viaja,

Quien no lee, Quien no oye música, Quien no encuentra gracia en si mismo..."

Pablo Neruda 
AZEVEDO FILHO, João D’Anuzio Menezes de. A produção e a percepção do turismo em

Parintins, Amazonas. 2013, 210 f. Tese (Doutorado). Faculdade de Filosofia, Letras e

Ciências Humanas. Universidade de São Paulo (USP). São Paulo, 2013.

\section{RESUMO}

O turismo é uma atividade extremamente complexa na sua interpretação e forma prática de se realizar. O que dirá dessa atividade em uma região que, devido a sua grandeza e diversidade em todos os sentidos, apresenta um conjunto de fatores a serem analisados e discutidos de forma a possibilitar sua interpretação e conclusões realistas e que levem em consideração essa diversidades e maneira de ser no mundo atual. Este trabalho tem o objetivo de compreender a realidade do turismo na Amazônia, levando em consideração essas características e tem como campo de estudo o município de Parintins, que não é um lugar qualquer na Amazônia, pois não passou despercebida pelos viajantes que adentraram a região desde tempos coloniais. Sua localização e sua beleza foram notadas e serviram para que aqui ali se instalasse um pequeno núcleo para atender aos interesses da metrópole portuguesa e da igreja. Constituiu-se como cidade e como município e se transformou num importante polo econômico na região do Baixo Amazonas. A força de sua gente, formada sempre por gente da terra e por aqueles que de alguma forma a adotaram como materna, forjou um novo ritual de tradições e miscigenação de culturas dando origem aos Bois-bumbás Garantido e Caprichoso que pela sua beleza e identidade deram origem ao Festival Folclórico de Parintins, o maior do interior do estado do Amazonas e que transformou a cidade no principal centro de turismo no mês de junho. Apesar disso, o turismo em Parintins ainda carece de reflexão e de um planejamento que realmente introduza novas formas de se fazer turismo, inclusive ultrapassando o período do festival, pois o turismo não pode se restringir aos dias que antecedem e se realiza o evento, ultimo fim de semana de junho, sexta, sábado e domingo. É preciso refletir sobre as práticas de turismo existentes em outros eventos importantes como a Festa religiosa de Nossa Senhora do Carmo, o Carnailha - carnaval de rua, o festival de Pastorinhas, mas principalmente, também, considerar o fluxo de turistas que desembarcam em Parintins vindos de todas as partes do mundo em transatlânticos. Esses turistas frequentam a região localizada entre a foz do rio Amazonas e Manaus, de outubro a maio de cada ano, trazendo desejos e imagens que precisam ser bem estimulados e que os farão voltar outras vezes. Isso gera divisas para o país e para a região. Conclui-se que o turismo em Parintins deve ter um planejamento que leve em consideração as diversão regiões turística locais, pois existe potencial turístico em vários pontos do território como a região da Valéria, onde as belezas naturais e a vida tradicional do trabalhadores-ribeirinhos atraem turistas de cruzeiros que circulam pelo rio Amazonas. Um Plano de Turismo para o município deve contemplar a realização do grande Festival Folclórico, com a disputa entre os bois Garantido e Caprichoso, mas também outras opções de lazer e turismo em torno do evento principal.

Palavras chaves: Amazônia - Comunidade - Turismo - Folclore - Espaço 
AZEVEDo FILHO, João D'Anuzio Menezes de. Production and the Perception of Tourism in Parintins, Amazonas State. 2013, 210 f. Tese (Doutorado). Faculdade de Filosofia, Letras e Ciências Humanas. Universidade de São Paulo (USP). São Paulo, 2013.

\begin{abstract}
Tourism is an activity that is extremely complex in its interpretation and difficult to produce in its practical form. This activity, in a region that owing to its greatness and diversity in every sense, portrays a group of factors that must be analised and discussed in such a way that makes its interpretation possible as well as arriving at realistic conclusions and that takes this diversity and existence in the real world into consideration. This study has as its objective the comprehension of the reality of tourism in the Amazon, taking into consideration these characteristics and, as a field of study, the municipality of Parintins. Parintins isn't just any place in the Amazon because it did not go unnoticed by the travellers that have entered the region since colonial times. Its location and its beauty were noted and it served as a place where a small center was installed to attend the Portuguese crown and the church. It became a town and municipality and then transformed itself into an important economic center in the lower Amazon region. The strength of its people, always formed by local people and by those who in some way adopted the place as their own, forged a new ritual of traditions and mixture of cultures, thus creating the Caprichoso and Garantido bumbá guilds that, through their beauty and identity, were the beginning of the Parintins Folklore Festival, the biggest in the interior of the Amazon State and one which transformed the city into the principal center for tourism in the month of June. Despite this, tourism in Parintins still needs reflexion and planning that really introduces new forms of tourism, including going beyond the period of the festival because tourism cannot be limited just to the days in which the festival is held the Friday, Saturday and Sunday of the last weekend in June. It is necessary to think about the practices of existing tourism in other important events such as the religious festival of Our Lady of Carmel, Carnailha (street carnival), and the festival of the Pastorinhas, but also principally, consider the flow of tourists that disembark in Parintins coming from all over the world in transatlantic cruise ships. These tourists visit the region between the mouth of the Amazon river and Manaus from October to May every year, bringing desires and images that need to be stimulated and which will make them come back again. This generates wealth for the country and for the region. We can conclude that tourism in Parintins must have planning that takes into consideration the diverse local touristic regions because there is tourist potential and in various areas of the territory such as the Valéria region where the natural beauty and the traditional life of the riverside dwellers attract the cruise ship tourists that travel the Amazon river. A plan for tourism for the municipality must contemplate the Folklore Festival, with its dispute between Garantido and Caprichoso, but also other leisure options and tourism close the principal event.
\end{abstract}

Keywords: Amazon - Community - Tourism - Folklore - Space 
AZEVEDO FILHO, João D’Anuzio Menezes de. A produção e a percepção do turismo em

Parintins, Amazonas. 2013, 210 f. Tese (Doutorado). Faculdade de Filosofia, Letras e

Ciências Humanas. Universidade de São Paulo (USP). São Paulo, 2013.

\section{RESUMEN}

El turismo es una actividad extremadamente compleja en su interpretación y forma práctica de realizarse. Lo que dice de esa actividad en una región, que debido a que su grandeza y diversidad en todos los sentidos, presenta un conjunto de factores a ser analizados y discutidos de forma a posibilitar su interpretación y conclusiones realistas y que lleven en consideración esa diversidades y manera de ser en el mundo actual. Este trabajo tiene el objetivo de comprender la realidad del turismo en la Amazônia, llevando en consideración sus características y tiene como campo de estudio el municipio de Parintins. Parintins no es un lugar cualquiera en Amazônia, pues no pasó despercebida por los viajantes que se adentraron en la región desde tiempos coloniales. Su localización y belleza fueron notadas y sirvió para que aquí se instalase un pequeño núcleo para atender los intereses de la metrópoli portuguesa y de la iglesia. Se constituyó como ciudad y como municipio y se transformó en un importante polo económico en la región del Bajo Amazonas. La fuerza de su gente, formada siempre por gente de la tierra y por aquellos que de alguna forma la adoptaron como materna, forjó un nuevo ritual de tradiciones y mestizaje de culturas dando origen a los Bois-bumbás Garantido y Caprichoso que por su belleza e identidad dieron origen al Festival Folklórico de Parintins, el mayor del interior del estado de Amazonas y que transformó la ciudad en el principal centro de turismo en el mes de junio. Sin embargo el turismo en Parintins aún carece de ponderación y de una planificación que realmente introduzca nuevas formas de hacer turismo, incluso finalizado el período del festival, pues el turismo no se puede restringir a los días que anteceden y de realización del evento, último fin de semana de junio, el viernes, el sábado y domingo. Es necesario reflejar sobre las prácticas de turismo existentes en otros eventos importantes como la Fiesta religiosa de Nuestra Señora del Carmen, el Carnailha, el carnaval de calle, el festival de Pastorinha, pero principalmente, también, considerar el flujo de turistas que desembarcan en Parintins llegando de todas las partes del mundo en transatlánticos. Esos turistas frecuentan la región entre la hoz del río Amazonas y Manaus de octubre a mayo de cada año, trayendo deseos e imágenes que necesitan ser bien estimulados y que les harán volver otras veces. Eso genera divisas para el país y para la región. Se concluye que el turismo en Parintins debe tener una planificación que tenga en consideración las diversas regiones turística locales, pues existe potencial turístico y varios puntos del territorio como la región de Valéria, donde las bellezas naturales y la vida tradicional de los trabajadores ribereños atraen turistas de cruceros que cruzan el río Amazonas. Un Plan de Turismo para el municipio debe contemplar la realización del gran Festival Folklórico, con la rivalidad entre los Bois Garantido y Caprichoso, pero también otras opciones de ocio y turismo en torno al evento principal.

Palabras claves: Amazônia - Comunidad - Turismo - Folklore - Espacio 


\section{LISTA DE MAPAS}

Mapa 1 Localização da cidade de Parintins - Amazonas 27

Mapa 2 Localização da ilha Tupinambarana-Amazonas 28

Mapa 3 Planta: crescimento do espaço urbano de Parintins 1853 - 2012

Mapa 4 Planta: Parintins por bairros - $2012 \quad 84$

Mapa 5 Tipos de rios da Amazônia no município de Parintins, Amazonas 137

Mapa 6 Compartimentação geomorfológica do município de Parintins, $2013 \quad 144$

$\begin{array}{lll}\text { Mapa } 7 & \text { Aspectos físicos de Parintins } & 148\end{array}$

Mapa 8 Assentamentos Rurais em Parintins 153

Mapa 9 Clima de Parintins (isoietas anuais médias), 2013

Mapa 10 Localização de Unidades de Conservação e Terra Indígena em Parintins 158

Mapa 11 Distribuição da população em Parintins-AM, $2010 \quad 160$

Mapa 12 Divisão Regional de Parintins segundo o Plano Diretor, 2006163

Mapa 13 Ambiente e Turismo em Parintins-AM 170

Mapa 14 Mapa da Região da Valéria e Paraná de Parintins 173

Mapa 15 Mapa da Região da Valéria - "Boca da Valéria" 175

Mapa 16 Mapa mental da Região da Valéria 185

\section{LISTA DE TABELAS}

Tabela 1 Ranking dos países receptivos quanto à desembarque de turistas e receitas $-2010-2011$

Tabela 2 População de Parintins e taxa de crescimento entre 1960 e 2010

Tabela 3 Preços dos pacotes de ingressos para o Festival Folclórico de Parintins (2011-2013)

Tabela 4 Navios de Cruzeiros e Passageiros no Amazonas - 2003-2011 116

Tabela 5 Comunidades da região da Valéria e Paraná de Parintins: estimativa de população e porcentagem, 2012 


\section{LISTA DE FIGURAS}

Figura 1 Desembarques e receitas internacionais do turismo 1990-2011 46

Figura 2 Chegadas e receitas do turismo internacional do mundo (1990-2012) 47

Figura 3 Mapa datado de 1556, creditado a Giovanni Battista Ramusio 70

Figura 4 Porto de Parintins, maio/2013 86

Figura 5 Aeroporto Júlio Belém, Parintins, Amazonas, maio/2013 86

Figura 6 Festas de Boi pelas ruas de Parintins 90

Figura 7 Festa de Nossa Senhora do Carmo, Parintins, julho/2012 93

Figura 8 Carnailha, carnaval de Parintins, Amazonas, $2013 \quad 94$

Figura 9 Triciclo em dia de visitação de turistas de cruzeiros 95

Figura 10 Roteiros de dois cruzeiros com destino à Manaus 97

Figura 11 Bumbódromo: suas cadeiras e arquibancadas para cada Boi 105

Figura 12 Turistas em Parintins segundo a origem declarada: Junho 2012107

Figura 13 Turismo em Parintins segundo meio de transporte 108

Figura 14 Embarcação regional de transporte de passageiros e cargas 109

Figura 15 Percentual de turistas em Parintins segundo origem declarada: Junho 110 2012

Figura 16 Festival de Parintins: pesquisa de satisfação, junho de 2012

Figura 17 Festival de Parintins: pesquisa de satisfação (cont), junho de 2012

$\begin{array}{lll}\text { Figura } 18 & \text { Bases conceituais da Cartografia } & 130\end{array}$

Figura 19 Perfil esquemático das formações da planície amazônica 141

Figura 20 Ambientes fluviais da Amazônia 142

Figura 21 Cota d'água do Rio Amazonas em Parintins, ano de 2011

Figura 22 Parintins: distinção entre o período da enchente e da vazante dos rios... 150

Figura 23 Variação sazonal da temperatura e precipitação na cidade de Parintins 154

Figura 24 Rede urbana da Amazônia 161

Figura 25 Transatlântico em frente da serra de Parintins na "Boca da Valéria" 176

Figura 26 Santa Rita de Cássia da Valéria: estrada, comunidade, escola ... 180

Figura 27 Artefatos cerâmicos de Santa Rita da Valéria 181

Figura 28 Comunidade de São Paulo: receptivo da vazante e na cheia 182

Figura 29 Comunidades evangélicas Bete Semes e Betel 184 


\section{LISTA DE QUADROS}

Quadro 1 Festas tradicionais dos Bois de Parintins precedentes ao Festival 91 (2011-2012)

Quadro 2 Calendário de Eventos da SICTUR e orçamento em 2010, 120 Parintins

Quadro 3 Projetos de Reforma Agrária - INCRA - Parintins - AM 152

Quadro 4 Características socioambientais das sub-regiões de Parintins, $2013 \quad 162$

Quadro 5 Parintins: população, área e densidade demográfica por Sub- 164 regiões (2010)

Quadro 6 Quadro síntese dos agrupamentos dos lugares - Parintins 


\section{LISTA DE ABREVIATURAS E SIGLAS}

AHIMOC Administração das Hidrovias da Amazônia Ocidental

AM

Estado do Amazonas

ANA

Agência Nacional das Águas

APA

Área de Proteção Ambiental

APP

Área de Proteção Permanente

CAT

Centro de Atendimento do Turista

CESP

Centro de Estudos Superiores de Parintins

CPRM

Companhia de Pesquisa de Recursos Minerais

DETRAN Departamento Estadual de Trânsito

DINTER Doutorado interinstitucional

DNIT Departamento Nacional de Infraestrutura de Transportes

EMBRATUR Empresa Brasileira de Turismo

FAPEAM Fundação de Amparo à Pesquisa do Estado do Amazonas

FES Formação Econômica e Social

GGI Gabinete de Gestão Integrada

IBAMA Instituto Brasileiro do Meio Ambiente e Desenvolvimento

Sustentável

IBGE Instituto Brasileiro de Geografia e Estatística

INCRA Instituto Nacional de colonização e Reforma Agrária

LIBLOC Liga dos Blocos Carnavalescos de Parintins

MAG Movimento Amigos do Garantido

MDA Ministério do Desenvolvimento Agrário

MINTER Mestrado interinstitucional

MTur Ministério do Turismo

OMT Organização Mundial do Turismo

ONG Organização Não Governamental

ONU Organização das Nações Unidas

PA Projeto de Assentamento

PAE Projeto de Assentamento Agroextrativista

PNMT Programa Nacional de Municipalização do Turismo

PNT Plano Nacional de Turismo 
PROECOTUR Programa de Desenvolvimento do Ecoturismo na Amazônia

SDS

SICTUR

SIG

SIPAM

SNUC

UEA

UNWTO

USP

ZFM
Secretaria de Estado do Meio Ambiente e Desenvolvimento Sustentável

Secretaria Municipal da Indústria, Comércio e Turismo de Parintins

Sistema de Informação Geográfica

Sistema de Proteção da Amazônia

Sistema Nacional de Unidades de Conservação

Universidade do Estado do Amazonas

Unidet Nations World Tourism Organization

Universidade de São Paulo

Zona Franca de Manaus 


\section{GLOSSÁRIO DE TERMOS DO FESTIVAL DE PARINTINS}

Alegoria

Amo do Boi

Apresentador

Batucada

Boi

Boi de rua

Bumbódromo

Contrário

Cunhã-Poranga

Curral

Ensaio

Galera

Itens do Boi
Cenografias espetaculares que recriam as lendas, fábulas e ritos indígenas, concebidas sob o efeito tecnológico da engenharia da arte parintinense.

No Auto do Boi este personagem é o dono da fazenda. Tem por função proteger o boi e tirar versos, abordando temas variados, com ênfase no folclore e na Amazônia.

É a pessoa que conduz a festa. Tem como funções principais narrar e animar o espetáculo. É quem apresenta os outros itens.

É o conjunto de tocadores do boi Garantido, responsável pelo som e ritmo peculiares que acompanham as toadas.

Refere-se ao Boi-Bumbá Garantido ou ao Boi-Bumbá Caprichoso.

Festa tradicional dos Bois de Parintins caracterizada pelo desfile do Boi pelas ruas localizadas no lado da cidade destinado a cada um, respectivamente.

Centro de Convenções, palco da exibição do Festival Folclórico de Parintins. Em sua arena ocorre o confronto dos bois Garantido e Caprichoso.

É a forma como, na época do Festival, os brincantes e populares referem-se ao boi adversário. O "outro" boi é o contrário. Durante a apresentação do Boi no Bumbódromo, toda referência ao boi adversário é feita com essa expressão.

É a índia mais bela da tribo (e do Boi). Sua dança é um rito que fascina e encanta a aldeia. Personagem inserida no contexto da Lenda Amazônica ou Ritual Indígena por sua ligação com o universo mítico indígena.

Local destinado exclusivamente aos ensaios dos Bois-Bumbás, sendo composto por palco para a apresentação da banda oficial do boi, espaço para a dança em frente ao palco, bar com mesas e cadeiras e camarotes para acomodação dos membros da Diretoria. A Festa de cada Boi é realizada no seu curral.

Constitui-se de espaços musicais, destinados exclusivamente aos brincantes dos bois-bumbás, onde as letras das novas toadas são aprendidas, os passos são treinados as coreografias para cada toada são criadas pelos grupos de brincantes.

É como é chamada a torcida de cada Boi-Bumbá. É formada pelos admiradores do boi que, durante o espetáculo, vibram e cantam com a alma nas arquibancadas do Bumbódromo.

São as figuras folclóricas do boi-bumbá como a Sinhazinha da fazenda, Cunhã-poranga, Porta estandarte, Pajé, entre outras. 
Levantador

Mãe Catirina

Marujada

Pai Francisco

Pajé

Porta Estandarte

Ritual

Sinhazinha da

Fazenda

Toada

Tribo

Praça dos Bois
É o cantor das toadas, que envolvem e fazem vibrar brincantes e espectadores do Festival.

Personagem do Auto do Boi, é a mulher do vaqueiro que, estando grávida, manifesta ao marido o desejo de comer a língua do boi de seu patrão, levando o marido, Pai Francisco, a matar o boi mais querido da fazenda.

É o conjunto de tocadores do boi Caprichoso, responsável pelo som e ritmo peculiares que acompanham as toadas.

Personagem folclórico do Auto do Boi, Pai Francisco é o vaqueiro que para satisfazer o desejo da esposa grávida, mata um boi da fazenda de seu patrão.

É o principal item do Ritual Indígena. É o feiticeiro, o curandeiro da tribo, que por sua intercessão junto aos espíritos do sobrenatural e o uso de inalações, beberagens e chocalhos, domina os espíritos maus que assombram os índios da aldeia.

É a índia guerreira que defende o pavilhão do Boi-Bumbá. O estandarte é o símbolo maior que sintetiza todo o amor pelo Boi.

Teatralização e desenhos coreográficos que proporcionam uma viagem cênica ao mundo sobrenatural onde habitam os mitos indígenas e para os quais são realizados os ritos em defesa da cultura ancestral e do estabelecimento do bem sobre o mal para guardar o bem-estar das tribos.

Personagem que, junto com o Amo, simboliza a participação do branco no Auto do Boi. É a doce, singela e encantadora menina, filha do dono da fazenda que tem o boi como seu animal de estimação.

É a base do espetáculo, pois é a partir dela que se constrói a dramaturgia e a partitura musical com a qual todos os elementos do grande espetáculo se desenvolvem. É a musicalidade que encanta com seus passos "dois pra lá dois pra cá”.

Personagens que encenam o rico mundo étnico brasileiro. Por meio da teatralização dos ritos, momentos xamânicos e cenas do cotidiano indígena, retratam a cultura e a diversidade desses povos.

É a praça que fica atrás do Bumbódromo, construída em 2004. De um lado o Azul, do Caprichoso e do outro, o Vermelho do Garantido, com bares e lanchonetes, quadras de esporte etc. 


\section{SUMÁRIO}

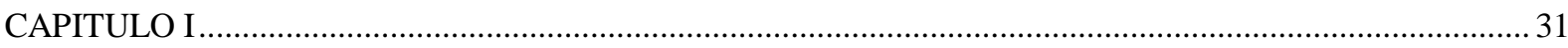

1 O TURISMO NA AMAZÔNIA: PARA ENTENDER O TURISMO LOCAL ............................................... 31

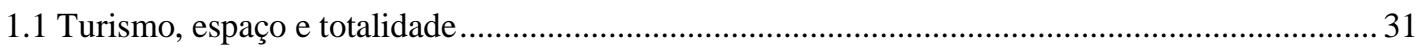

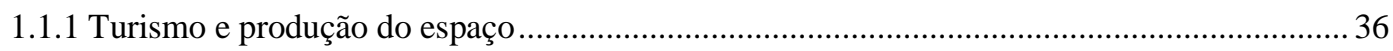

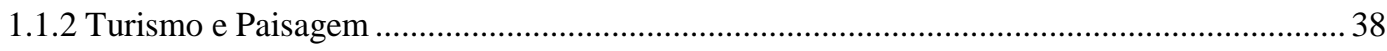

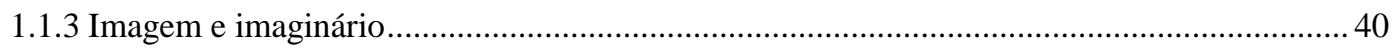

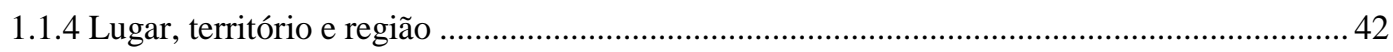

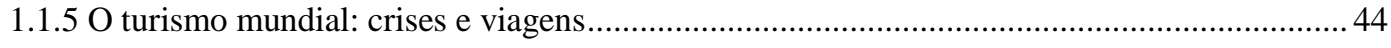

1.1.6 Turismo no Brasil: emergência e planejamento .......................................................... 49

1.1.7 Turismo para a Amazônia: turismo de natureza e ecoturismo..............................................53

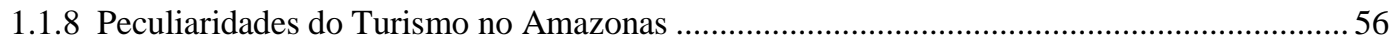

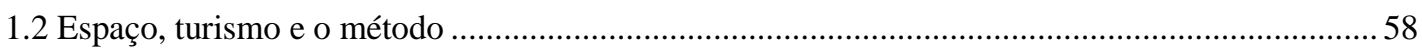

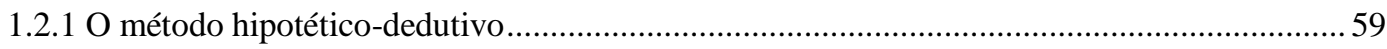

1.2.2 O método fenomenológico-hermenêutico ................................................................ 60

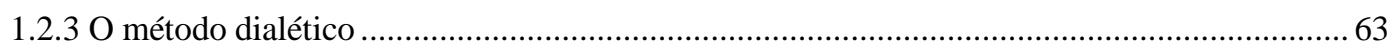

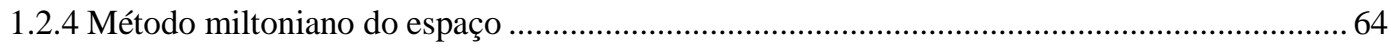

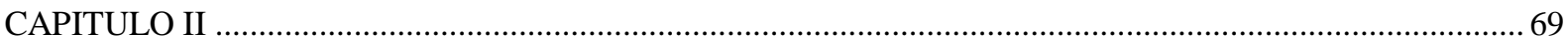

2 A CONSTRUÇÃO DA AMAZÔNIA: A FORMAÇÃO DE UMA REGIÃO EM VIAGENS E TURISMO ...69

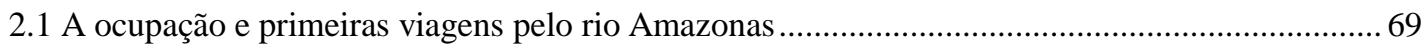

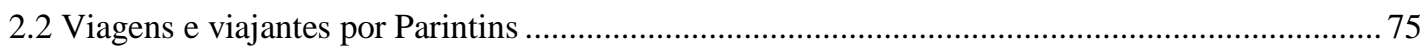

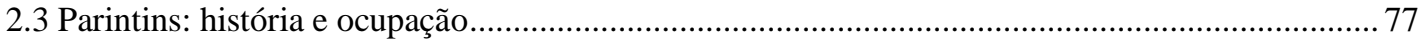

2.3.1 Parintins de vila à "capital da cultura e do folclore amazonense" .................................... 81

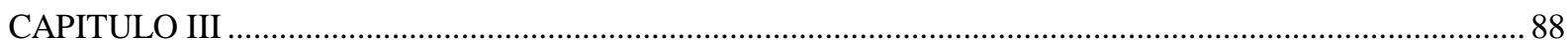

3 PARINTINS - BOI-BUMBÁ E OUTRAS PRÁTICAS TURÍSTICAS LOCAIS..........................................8 88

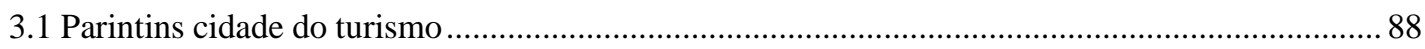

3.1.1 O Festival dos Bois-Bumbás Garantido e Caprichoso ................................................... 89

3.1.2 Nem só de Boi vive Parintins: religiosidade, carnaval e cruzeiros................................... 92

3.2 A imagem e o imaginário no turismo de Parintins em Manaus..................................................97

3.3 Turismo em Parintins, seus atrativos e suas características............................................... 100

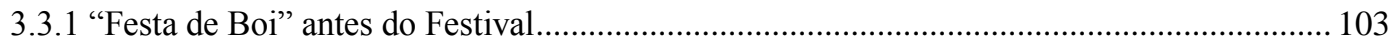

3.4 Sobre os turistas no Festival de Parintins .......................................................................... 107 
3.6 Cruzeiros pelo Rio Amazonas

3.6.1 Como se dá a preparação para a chegada dos navios de cruzeiros

3.6.2 Cruzeiros na Boca da Valéria

3.7 Turismo em Parintins para além do Festival Folclórico.....

3.7.1 O turismo além do Festival dos Bois

4.1 A Cartografia e seu uso no turismo e no meio ambiente.

4.3 Rumo a uma Cartografia do Meio Ambiente e do Turismo

4.3.1 Mapa da bacia hidrográfica em Parintins

4.3.3 Mapa dos aspectos físicos de Parintins: a vegetação

4.3.6 Áreas Protegidas: Unidades de conservação e Terras Indígenas em Parintins 156

4.3.7 Áreas Urbanizadas e distribuição da população. 159

4.4 O Mapa do Meio Ambiente e Turismo 162

5 O TURISMO NA REGIÃO DA VALÉRIA: CAMINHOS PARA UM TURISMO DE BASE COMUNITÁRIA. 171

5.1 As Comunidades da Região da Valeria. 172

5.1.1 Comunidade de várzea do Paraná de Parintins

5.1.2 A “Boca da Valéria” um novo espaço turístico 174

5.1.3 Comunidade de Santa Rita de Cássia. 177

5.1.4 Comunidade de São Paulo da Valéria 181 


\section{INTRODUÇÃO}

O turismo tem chamado a atenção de governos e sociedade pela sua capacidade de atrair recursos para os lugares onde ele acontece. É uma atividade que envolve ao mesmo tempo uma prática econômica e uma relação entre pessoas e lugares. Como atividade econômica, sem dúvida, é possível pensar em melhorias das condições de renda e trabalho, ainda que os resultados positivos dessa atividade sejam apropriados por uma minoria de empresários, enquanto os resultados negativos são distribuídos entre toda a população. Essa é uma forma de avaliar os danos causados pelo turismo nos centros urbanos e nas áreas rurais, mesmo sabendo que há sempre um esforço do Estado e da sociedade civil organizada para tornar essa atividade mais sustentável.

Nesse sentido, caminhamos para uma interpretação do turismo como um instante da vida de pessoas que aproveitam seu momento de não trabalho para conhecer outros lugares, outras pessoas, outras culturas. Um curto período em busca de lazer e de convivências. O turista não é um explorador ou um consumidor compulsivo. Não se trata de discutir apenas qual a capacidade de consumo de cada turista como faz a maioria dos estudos de demanda turística. Trata-se de perceber o turismo não apenas na sua complexidade e nas várias perspectivas motivacionais do turista, mas também nos laços afetivos deste com o meio (espaço) e suas atitudes em relação aos lugares.

Portanto, o turismo não pode ser interpretado de uma única maneira, por uma única perspectiva epistemológica de ciência e seu método, uma vez que se trata de uma atividade extremamente dinâmica e que envolve pessoas diferentes, com desejos e motivações diferentes. Nunca é o mesmo turista que visita um lugar e, mesmo que fosse, não são os mesmos desejos e gostos de antes. É preciso pensar nisso. Urry (1996) coloca exatamente que não existe apenas um olhar de uma pessoa enquanto turista. $\mathrm{O}$ olhar varia no tempo e no espaço, em cada momento da nossa história. Esses múltiplos olhares, em todas as épocas, significam que não existe apenas uma experiência universal verdadeira para todos os que se dizem turistas. $\mathrm{O}$ autor quer dizer que esse olhar do turista tem a ver com suas experiências enquanto não turista, na sua vivência diária de experiências e consciência social.

Por outro lado, há a população do local de recepção. O que se tem de estudo sobre as populações visitadas e seus anseios quanto ao turista visitante? Knafou (2001) é quem afirma que, na perspectiva do visitado, o turista incomoda, pois é um estranho, móvel e escorregadio. 
Mesmo num tempo de muita mobilidade, as pessoas nem sempre aceitam bem o que se move, o que é difícil de controlar e, também, fugidio. O autor coloca esse momento como uma "forma moderna de conflito de territorialidade", considerando que, de um lado têm-se os turistas (nômades) e do outro, os moradores (sedentários). Mas, lembra que nessa relação, em outro momento, um deles será nômade (turista) e o outro sedentário (morador visitado).

O turismo proporciona essa liberdade que muitas vezes incomoda, como diz Knafou. E é nesse ir e vir que se confrontam interesses divergentes. Um, na sua condição sedentária de morador, com seus hábitos, costumes e modo de viver e o outro na condição de visitante, diferente, distante, mas também com desejos de conhecer e se apropriar, mesmo que momentaneamente, dos lugares e espaços que frequenta. Isso pode resultar em diversos conflitos, mas é essa mobilidade de pessoas e grupos entre diferentes lugares que possibilita a construção de novos espaços, bem como mudanças em outros já consolidados. E isso a Geografia, como ciência, tem a obrigação de entender e de intermediar.

Buscar, pois, entender o turismo, isolando-o de sua inter-relação com o espaço e sua complexidade pode levar ao fracasso, afirma Cruz (2007). O turismo tem que ser estudado dentro do amplo contexto que envolve a compreensão de sua interação com vários agentes que se encontram em todas as partes do planeta. Em um mundo globalizado, o turismo parece viabilizar a integração entre os diversos espaços e afirmar a ideologia de um mundo sem fronteiras, tão defendida pelos neoliberais. É nesse sentido que devemos entender o turismo em suas múltiplas relações. É nesse sentido, também, que se faz necessário um planejamento consistente da atividade turística, politicamente correto e socialmente justo, que leve em consideração não só os interesses dos agentes de mercado do turismo, mas também os do visitante e do visitado.

Atualmente, o estudo do fenômeno turístico tem aumentado bastante, principalmente entre os economistas, antropólogos, sociólogos, turismólogos e geógrafos. A Geografia dirige seu foco para diversos momentos desse processo, seja no lugar de origem, no deslocamento e, principalmente, no lugar de destino. Pode-se afirmar que existe uma relação estreita entre geografia e turismo, pois, este só pode ser explicado a partir do estudo do espaço geográfico, considerando que o turista "viaja" para conhecer "lugares". Os estudos em Geografia do Turismo dizem respeito à análise dos espaços geográficos transformados em espaços para o turismo, tentando compreendê-lo no tempo e no espaço. É bom lembrar Cruz (2007), quando coloca que o principal objeto de consumo do turismo é o espaço, que é transformado em mercadoria e inserido no circuito de troca. 
Se o turismo se faz pelo consumo do espaço pelo turista e é uma atividade produtiva que transforma os espaços para a sua realização, devemos lembrar Milton Santos (2008), para quem a interpretação do espaço deve levar em consideração que este é formado por um sistema de objetos e ações que não podem ser considerados isoladamente, senão dentro do contexto histórico em que acontecem, sendo indissociáveis e também contraditórios.

A construção da Amazônia como porção do espaço brasileiro e de patrimônio da humanidade reflete bem as contradições existentes na sua longa história de ocupação e domínio. Os interesses capitalistas se fizeram sentir desde o início da colonização e se intensificam ainda hoje. Os conflitos criados no sentido de preservar a região, tida como um dos últimos recantos da natureza primitiva, entretanto, não inviabilizou a exploração de suas riquezas, seja de modo legal ou ilegal, e de sua gente. O modelo de ocupação da Amazônia, em tempo recente, foi centrado na perspectiva da urbanização da região, seja em polos de desenvolvimento industrial ou agrícola, fato bem analisado por Bertha Becker (1998). É desse período, também, a proposta pelo governo militar, de um mal sucedido programa de turistificação da Amazônia que ao invés de espelhar as belezas naturais acabou por expor a degradação ambiental provocada pelo avanço capitalista na região. $\mathrm{O}$ turismo seria uma forma de exploração racional dos recursos naturais e culturais sem destruir a Amazônia? Essa é uma questão que carece de mais estudos. Os casos existentes apontam para uma preocupação dirigida às capitais da região. Os resorts são um exemplo de inserção da atividade turística totalmente descolada da realidade amazônica. O nome "selva" ou jungle não transformam os hotéis e seus atrativos em atividade ecologicamente corretas.

Parintins é, por sua vez, uma referência de turismo no centro da Amazônia. O Festival Folclórico tornou-se um ícone da cultura amazonense dentro do imaginário popular de cultura amazônica e brasileira.

Este autor chegava a Parintins em 2004, para se dedicar a docência universitária no Centro de Estudos Superiores de Parintins, da Universidade do Amazonas, quando se deparou com a força que tem o Festival Folclórico, força de mobilizar as pessoas, de atrair a atenção, ocupando espaço em qualquer conversa. A opção por um dos Bois foi-lhe imposta rapidamente, tendo então que admitir sua preferência pela cor vermelha do Garantido que tem seu curral na mesma zona geográfica onde optou por residir. Mas, mais do que isso impressiona a movimentação da cidade antes, durante e um pouco depois do evento. São muitos turistas se movimentando na cidade, que chega a incomodar, dada a vida pacata a que se está habituado encontrar em cidades do interior da Amazônia. 
Outro fato curioso e que chama a atenção, são os turistas de cruzeiros que fazem parada em Parintins. Nos primeiros anos, foi-lhe fantástico ver aqueles enormes transatlânticos ancorados no pequeno porto, em frente à cidade. Parecia desproporcional a imagem do transatlântico ao lado de uma cidade pequena e dos barcos regionais, pequenos enfeites sobre as águas. Os turistas espalhavam-se pela cidade e lugares de encontro para ver uma breve apresentação do Boi Garantido ou do Boi Caprichoso. Só isso já valeria a dedicação para um estudo. Mas as surpresas continuam, pois a atividade docente em Geografia requer um constante contato com o expressivo espaço físico da região e sua atenciosa população em constantes trabalhos de campo. O contato com a região da Valéria, localizada na fronteira com o vizinho estado do Pará, foi uma surpresa, especialmente pela exuberante beleza das suas formações em pequenos morros, longos, acidentados, suaves, cobertos pela floresta, vales encaixados entre estes, pequenos rios, lagos, vida silvestre, pássaros de todas as cores e cantos, lagartos, infinitos aspectos da beleza da paisagem disposta num pequeno lugar da Amazônia. Sem falar na acolhedora população formada por agricultores, pescadores, artesãos, gente da terra. Todavia, durante os meses compreendidos entre outubro e abril, essa beleza e simplicidade são visitadas pelos navios que ancoram no rio Amazonas, em frente à serra de Parintins, antes de seguir para Parintins e Manaus. Os turistas estadunidenses e europeus, em sua maioria, lá se deparam com a vida pacata das comunidades locais adentrando-as pela boca do rio da Valéria. Não por outro motivo, o lugar de parada constante nos anúncios das agências de turismo é chamado "Boca da Valéria". Então, por que não pensar esse turismo na Amazônia e em Parintins? Um turismo praticado por pessoas que já conhecem a Amazônia e Parintins e que por isso querem voltar sempre; turismo dirigido àqueles que desejam conhecer e experimentar a aventura que é viajar pela região e conhecer um pouco da cultura local traduzida na arte de "dançar o boi" e um turismo voltado àqueles que buscam o exótico, o diferente, novas fronteiras, novas paisagens para fotografar e guardar na memória, como os turistas de cruzeiros. Perceber que o turismo, como uma atividade econômica, desperta naqueles que recebem os turistas o desejo de explorar, também, seu potencial de consumo. Assim se faz o turismo durante o Festival Folclórico e durante a estadia dos cruzeiros, a busca de aproveitar o momento para viabilizar uma atividade comercial, de troca. Que turismo é esse? Diversificado e complexo, além de pouco estudado na possibilidade de suas várias interpretações e na visão dos que o vivenciam.

O estudo do turismo requer múltiplos olhares e é nesse sentido que a pesquisa aqui proposta caminhará. A Geografia, como ciência que tem se dedicado também ao estudo da 
relação da sociedade com o meio onde vive, tem condições de abordar o turismo de forma ampla, compreendendo os processos de produção e transformação de novos espaços. Métodos de análise empregados pela Geografia possibilitam essa abordagem, seja através da observação criteriosa e crítica, seja pela análise da relação material e simbólica que a sociedade mantém com o lugar, sem esquecer a análise como essa produção do espaço se dá, dentro de um contexto capitalista globalizado.

O caso do turismo em Parintins caracteriza bem essa dimensão da totalidade, pois os eventos turísticos são permeados por interesses que extrapolam a escala local e até mesmo a nacional. Significa dizer que as ações aqui impressas não tem nada a ver com as pessoas daqui. A mídia transforma tudo em espetáculo e um espetáculo a ser visto pelos de fora. Consomem-se produtos que são consumidos em qualquer lugar do mundo durante os eventos. Mas, é importante lembrar que, as manifestações culturais, caracterizadas principalmente pela ação de "dançar o boi" se mantêm como um bem do povo local e ocorrem não somente nos três dias do grande evento, mas também em todos os outros dias do ano, por meio daqueles que aqui vivem e admiram o seu Boi. É tanta a força que vem da cultura do Boi-Bumbá que, em Parintins, todas as marcas de produtos têm que ter uma versão azul, para o Caprichoso e uma vermelha para o Garantido. A Coca-Cola, o Bradesco e a Nestlé já experimentaram essa imposição e é provável que, mesmo assim, não deixaram de obter lucro.

O turismo tem sua realização pelo consumo de espaços. No entanto, não se pode dizer que o mesmo acontece com o lugar. Lugar não é espaço, lugar é o espaço transformado em ambiência, lócus da criação, da realização individual, das relações pessoais com o espaço. Tuan (1983) fala desse espaço como "topofilia" que são passíveis de transformação em lugar pelo trabalho, no sentido de sua ocupação, uso e significado social, ou seja, ganham um caráter simbólico, de intimidade e afetividade, vira cultura. Milton Santos (2004b) vai dizer que o lugar é onde as coisas acontecem, onde o mundo se realiza e nessa relação o mundo se refaz e ganha nova interpretação. Assim entendemos a produção de espaços turísticos nos lugares aqui estudados, fruto da articulação do lugar com o mundo, porém cheios de possibilidades de reflexão, de contradições e de reação. Para, enfim, construir um novo, um diferencial uma nova forma de se relacionar com o todo.

Parintins é, desde muito tempo, um lugar para ser apreciado. Desde o período colonial já despontava como o lugar da possibilidade, o lugar ideal para o repouso, para o abastecimento, o porto de lenha. Posteriormente, o lugar do controle da navegação, de arrecadação, do entreposto do cacau, da borracha, da juta, da castanha. O lugar da diversão, 
do lazer e do turismo. Parintins é desde sempre o lugar para tudo, mais do que o lugar dos seus moradores que têm que dividir suas belezas e suas riquezas com os de fora. É também lugar de resistência, seja pelos Tupinambarana e outros grupos contra a ocupação de suas terras, seja pela emancipação política da Província e do Estado, seja pela afirmação de sua condição de cidade e município. Parintins e sua gente sempre buscaram resistir, para não perder a possibilidade de se tornar um centro de referência e centro regional.

Parintins é um dos 62 municípios do Estado do Amazonas, sendo o segundo em população conforme o Censo 2010 (IBGE, 2011). Faz parte da 9a Sub-região do Amazonas, Região do Baixo Amazonas, que inclui ainda os municípios de Nhamundá, Barreirinha, Boa Vista do Ramos, Urucará e São Sebastião do Uatumã. É composto basicamente por dois distritos: Mocambo (oeste) e o distrito sede, Parintins (leste).

A cidade Parintins, sede do município, dista $360 \mathrm{~km}$ em linha reta e $400 \mathrm{~km}$ via fluvial, da capital do estado (Mapa 1) e a data de sua fundação está definida em 1796 (IBGE, 2010).

Formando uma pequena ilha à margem direita do rio Amazonas, a sede municipal está assentada em um bloco de terras altas, provavelmente desprendido do conjunto maior de terra firme que se prolongam para o sul e leste, decorrente de uma falha que se estende do rio Madeira às proximidades da serra de Parintins, no sentido NE-SW (COSTA et al, 1996). Essas terras altas correspondem à Formação Alter do Chão. A ilha se associa a um conjunto de deposições sedimentares holocênicas (Quaternário) que se inicia nas proximidades da cidade de Itacoatiara, na foz do rio Madeira, e se estende até a cidade de Parintins, denominada ilha de Tupinambarana, a maior ilha fluvial do Brasil. Nessa faixa forma-se uma rede de lagos, furos e paranás, cobertos por uma densa floresta, parecendo mais um arquipélago. A separação das terras altas das terras de várzea é feita, em boa parte, pelo Paraná do Ramos. 


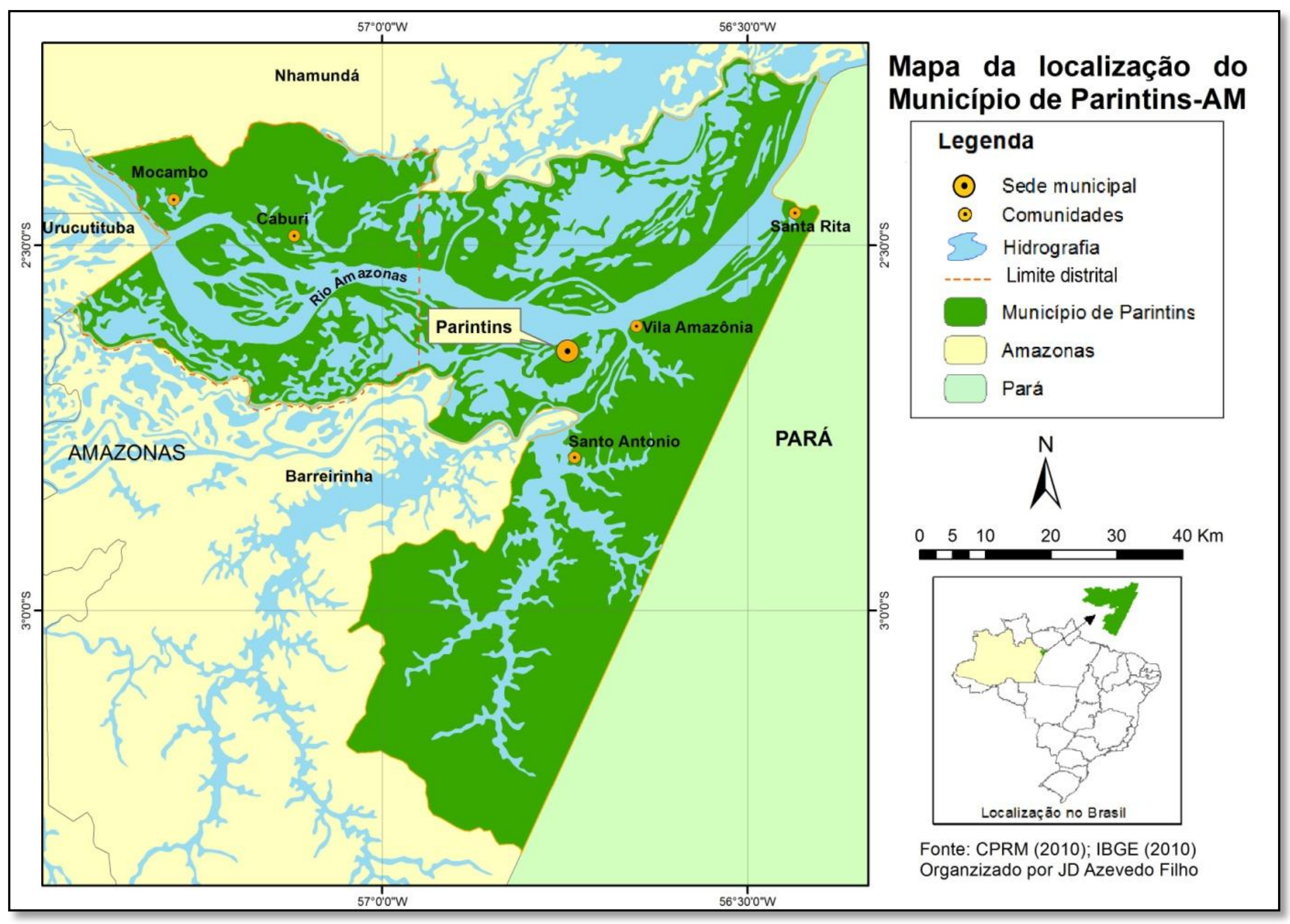

Mapa 1 - Localização do município de Parintins, Amazonas 
É comum se confundir a ilha de Parintins com a ilha Tupinambarana, porém essa última abrange oito municípios: Parintins, Barreirinha, Urucurituba, Urucará, Boa Vista do Ramos, Maués, Itacoatiara e Nova Olinda do Norte, sendo o município de Urucurituba o único que está totalmente dentro da ilha (Mapa 2).

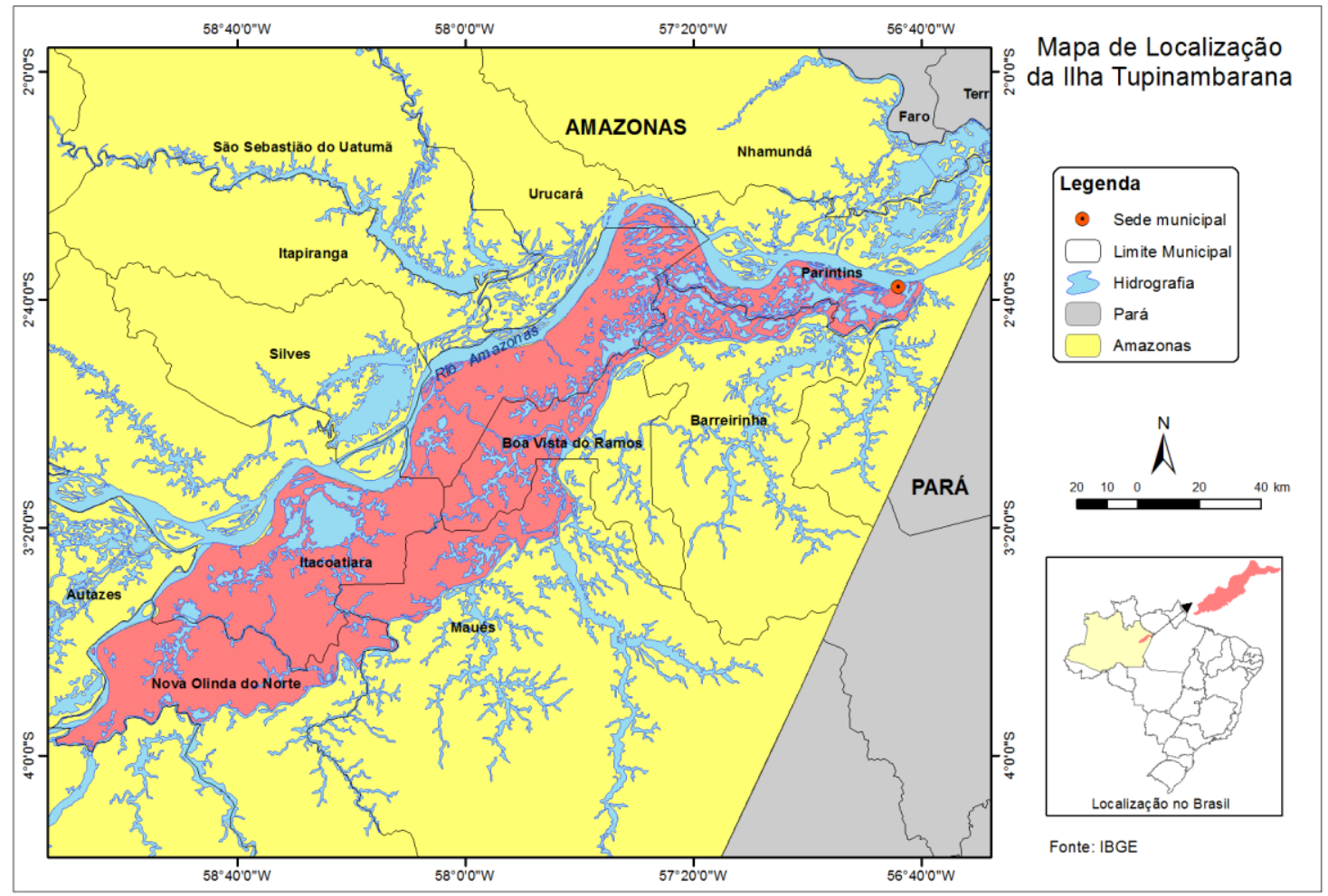

Mapa 2 - Localização da Ilha Tupinambarana, Amazonas

A pesquisa teve como objetivo compreender o processo de produção do turismo em Parintins, no estado do Amazonas, a partir da percepção que os atores envolvidos têm sobre o turismo. Para alcançar esse objetivo foi necessário conhecer o processo de produção e ocupação do lugar enquanto território e lugar de morada e de criação cultural, para então entender a produção do Festival e da midiatização do evento, bem como os problemas impostos pela turistificação do lugar.

Foi necessário também conhecer e compreender as atividades turísticas além do Festival para perceber que nem só de festival folclórico vive o município de Parintins. Nesse 
sentido, a partir das experiências do autor na região, e o uso de técnica cartográfica de síntese possibilitou a definição de áreas ambientais e turísticas e a produção de um mapa temático contendo essa diversidade de espaços e potencialidades.

Para aprofundar as experiências turísticas fora do contexto do Festival Folclórico e da cidade de Parintins, definiu-se um estudo de caso na área definida no mapa síntese ambiental e turístico correspondente a Região da Valéria e Paraná de Parintins. Principalmente, para compreender a lógica de apropriação do espaço para o turismo na perspectiva dos agentes da turistificação que atuam com turismo de cruzeiros na área definida e como a população local tem se organizado para atuar como receptora desse tipo de turismo.

O primeiro dos pressupostos que nortearam a pesquisa é o de que em Parintins, como em outros lugares da região, o turismo vem sendo apropriado pelos interesses capitalistas que, além de desconfigurar a cultura e o uso tradicional das riquezas naturais, trazem poucos benefícios para as populações envolvidas. Todavia, percebeu-se que a grandiosidade midiática do apogeu do evento, que envolve os três últimos dias de apresentação, no Bumbódromo, realmente transforma o Festival de Parintins em um evento nacional e global, como acontece com outros eventos, como o Carnaval do Rio de Janeiro, por exemplo. No entanto, a festa de Boi-Bumbá, parte da cultura local, não se esgota nesses três dias. As atividades pré-festival, nos currais e nas ruas, são presenciadas e participadas por grande parte dos moradores locais que reconstituem a festa como arte e cultura popular, ficando os dias de apresentação final para os turistas, que em sua maioria, pagam e tem acesso ao Bumbódromo. Dessa forma, o lado tradicional, que envolve a cultura local, não foi desconfigurado, mas foi e continua sendo apropriada pelo capitalismo para maximização do lucro e circulação do capital.

O segundo é de que a "Boca da Valéria" só existe enquanto criação dos agentes que atuam no turismo de transatlânticos. A criação de um ideário/simulacro como este se deve à necessidade de mostrar o exótico, o natural, a vida do homem amazônico, forjada no aparente, sem mostrar suas contradições, a realidade vivida por homens e mulheres que enfrentam no seu dia a dia as dificuldades de morar na floresta sem o apoio do Estado para produzir e escoar sua produção, ou mesmo participar do planejamento da atividade turística no lugar.

A tese aqui desenvolvida apresenta cinco capítulos nos quais se busca entender esse processo de produção do espaço na Amazônia, e no Amazonas, o que se faz a partir da experiência no município de Parintins. 
Nesse sentido, no primeiro capítulo será discutido o turismo na região, a partir dos projetos implementados no Brasil e para a Amazônia, com reflexo nas políticas de turismo no estado do Amazonas e em Parintins. Mas, é necessário primeiramente discutir os conceitos que envolvem a pesquisa e seus fundamentos teóricos e metodológicos, de modo que se possa dar solidez às discussões que se seguirão.

No segundo capítulo, defendemos ser necessário lançar uma luz sobre o lugar objeto de estudo, por acreditar que só poderemos entender o turismo na região se entendermos o processo histórico que dá origem à Amazônia e a torna um "mito", vislumbrado e desejado desde sua colonização no século XVI e que persiste até hoje com o turismo. Parintins tem uma história que caminha de sua apropriação para os domínios coloniais até a sua definição com cidade do folclore amazonense.

No terceiro capítulo, busca-se descrever o Festival de Parintins e a manifestação folclórica e cultural que é a arte de dançar o Boi-Bumbá dos Bois Garantido e Caprichoso, que transforma Parintins em cidade turística, principalmente a partir dos anos 1990. Mas, busca-se também perceber que o turismo em Parintins se faz por meio de outros eventos como o Carnailha, a Festa de Nossa Senhora do Carmo e a visitação dos turistas de cruzeiros.

No quarto capítulo, abre-se para possibilidade de se definir áreas de turismo no município. Para isso utiliza-se a técnica da Cartografia Temática. A partir da discussão do desenvolvimento dessa ciência junto com a Geografia, conclui-se que é possível, com o uso de técnicas de análise e síntese cartográfica, chegar a um produto cartográfico que represente um conjunto de atributos bem definidos e diferenciados que possam traduzir a diversidade de oportunidades de atuação turística no município.

No quinto capítulo, optou-se por analisar uma das áreas definidas no mapa anterior, tendo sido escolhida a região da Valéria e Paraná de Parintins que, não por acaso, é a área onde os navios de cruzeiros fazem parada para visitação. O objetivo é compreender como se instalou essa iniciativa e como os comunitários se envolvem com a atividade turística e a dividem com seus afazeres de agricultores e pescadores. Nesse sentido parte-se do pressuposto que é possível construir na Região da Valéria um Projeto de Turismo de Base Comunitária que favoreça a organização dos comunitários e o melhor aproveitamento do potencial turístico do lugar em benefício de todos. 


\section{CAPITULO I}

\section{O TURISMO NA AMAZÔNIA: PARA ENTENDER O TURISMO LOCAL}

É sabido que a atividade turística afeta diretamente a população onde ocorre. Em qualquer parte do mundo essa atividade traz inegável admiração pela possibilidade que coloca de imediato: de crescimento econômico e melhoria da renda da população local. A Amazônia, geralmente caracterizada pela presença de uma grande biodiversidade e de recursos naturais (vegetais e minerais), apresenta, por outro lado, municípios com baixo desempenho econômico, que se reflete nas precárias condições de sua população. Frente a isso, o turismo aparece como uma salvação. No entanto, muitos dos projetos desenvolvidos na região são totalmente desconectados da realidade local, demonstrando sua imposição para os municípios e as comunidades atingidas e não permitindo uma maior participação da população nos benefícios do turismo. Nesse sentido, faz-se necessário entender o processo de turistificação da região e compreendê-la dentro de um contexto maior que é das Políticas Nacionais e dos interesses comerciais que estão por trás.

\subsection{Turismo, espaço e totalidade}

Com certeza, o turismo é uma atividade econômica que tem despontado como um dos grandes impulsores do crescimento em países em desenvolvimento e principalmente nos já desenvolvidos, ditos centrais. Sua capacidade de articular o espaço local a um circuito mais amplo, nacional ou até mesmo internacional, nos dá a real dimensão do seu poder enquanto organizador e produtor de espaço geográfico.

Por outro lado, há uma discussão acadêmica sobre sua condição enquanto disciplina acadêmica: O turismo é uma ciência? Eis aí a grande questão que o coloca no centro da discussão de pesquisadores do turismo e de ciências afins, como a História, a Geografia, a Sociologia, a Economia.

Lohmann e Panosso Neto (2012) já alertaram sobre a dificuldade dos pesquisadores em turismo de se preocuparem com questões epistemológicas. Para eles, esses investigadores 
estariam mais preocupados em questões práticas, deixando de lado questões mais filosóficas. Daí a escassez de trabalhos sobre esse tema.

Os citados autores reconhecem que um estudo epistemológico é importante para todas as ciências, justamente porque "estabelece uma revisão do conhecimento de determinado assunto e oferece critérios para a aceitação desse conhecimento" (LOHMANN; PANOSSO NETO, 2012, p. 20).

A interdisciplinaridade tem sido defendida como uma das bases de sustentação do conhecimento em turismo. $\mathrm{O}$ apoio de ciências já consolidadas como a Geografia, a Sociologia, a Ciência Política, a Economia, o Direito entre outras, são apresentadas em vários modelos como base para a compreensão do "mundo do turismo". Tibe (2004) é um dos autores que aponta dois modos de desenvolvimento do conhecimento em turismo. O primeiro dado pelas agências de viagens, companhias aéreas, meios de hospedagem, ou seja, empresas e agentes envolvidos com o turismo, e, de outro lado, os conhecimentos produzidos no meio acadêmico, universidade e centros de pesquisas (LOHMANN; PANOSSO NETO, 2012, p. 22-23). Essa afirmação implica reconhecer a complexidade do conceito de turismo, ao mesmo tempo que essa dualidade caminham juntas e fazem do turismo uma realidade que interfere na vida política, econômica e social de vastas áreas do mundo afora.

Ainda sobre a condição de ciência do turismo, Lohmann e Panosso Neto (2012) indicam três correntes: a primeira afirma que o turismo não é uma ciência, mas caminha para tornar-se uma, pois está passando por etapas trilhadas por outras que hoje são consideradas ciências; a segunda, afirma que o turismo não é e nunca será uma ciência, visto ser apenas uma atividade humana, não havendo um objeto definido, muito menos um método de estudo particular, sua apreensão se dá com auxilio das ciências já existentes; e a última, refere-se ao grupo de pesquisadores que dizem que o turismo é uma ciência por apresentar um corpo teórico maduro e significativo, apesar de que não terem conseguido comprovar tal afirmativa (LOHMANN; PANOSSO NETO, 2012, p. 23).

Boullón (2003) é categórico em afirmar que "o turismo não é uma ciência" (p.19). Para ele, para ser ciência, o turismo teria que nascer de uma teoria. No entanto, esta surgiu espontaneamente de uma realidade e foi se consolidando a partir do conhecimento e das descobertas de outros campos, citando o progresso da navegação, a invenção da ferrovia, do automóvel e do avião. 
O professor Eduardo Yázigi, em artigo recente, aponta como um equívoco considerar o turismo como ciência, compartilhando com o pensamento de Boullón, quando afirma que como ciência precisaria que surgisse uma teoria, uma explicação bem sucedida da complexidade do objeto tratado, mas o turismo não é uma ciência, "porque não logra sequer ser categoria de análise", como tal "ninguém chegou a uma síntese de seu fenômeno por inteiro", pelo menos até o momento (YÁZIGI, 2012, p. 36).

Boullón também enfatiza que o turismo não é uma indústria. É comum encontrarmos citações sobre a "indústria do turismo", defendida com o argumento de que essa atividade para acontecer envolve diversos setores da economia, não só o de serviços, implicando na produção de uma mercadoria especial que é disponibilizada ao turista. Para Boullón (2003) o turismo não possui as características do setor secundário, produção e exploração de bens e recursos, "o turismo não explora os atrativos turísticos, só os utiliza" (p.30). O turismo também não é resultado de uma obra construída, apesar de necessitar delas para sua efetivação, como estradas, pontes, edifícios, etc. É, portanto, uma atividade do setor terciário ${ }^{1}$.

O turismo vem sendo estudado sob diversos ângulos, de acordo com o objetivo de cada trabalho. Por isso sua definição é complexa e ampla.

Douglas Pearce (2003) afirma que o turismo pode ser compreendido tecnicamente como um "conjunto de relações e fenômenos originados com as viagens e estadas temporárias de pessoas que estão viajando, sobretudo a lazer ou com finalidades recreativas". Para o autor, o turismo

diz respeito essencialmente a pessoas e lugares: a lugares que um grupo de pessoas deixa, visita ou que neles está de passagem; a outro grupo de pessoas, as que tornam possível a viagem. E outras ainda, aquelas com as quais cruzará pelo caminho (PEARCE, 2012, p.25).

Por outro lado, Knafou (2001) coloca que a palavra em si, turismo, nos conduz a várias interpretações (polissemia), pois se refere tanto a uma atividade humana e social,

\footnotetext{
${ }^{1}$ Apesar de aceitar as considerações de Boullón, a expressão "indústria do turismo" será utilizada nessa pesquisa respeitando a citação por outros autores que a emprega em seus trabalhos.
} 
importante para os dias atuais, como também, refere-se a todo o conjunto econômico ligado a atividade que lhe dá forma. É nesse sentido que a palavra se imbrica, pois fica difícil saber a que realidade se está referindo, principalmente entre a população em geral. Os técnicos e gestores podem falar de turismo se referindo a toda a cadeia produtiva do turismo que lhe dá forma, enquanto os intelectuais e pesquisadores referem-se a uma atividade que remete a relação entre pessoas e o meio onde essas pessoas habitam e visitam.

Para explicar o fenômeno turístico, Gastal (2005), argumenta que o ato de viajar é uma realidade mundial, viaja-se tanto por razões profissionais quanto por lazer. Por isso a autora afirma que devido a essa complexidade e diversidade no que se refere às viagens "o turismo também será um fenômeno social, cultural e econômico muito complexo" (GASTAL, 2005, p.11).

Nesse sentido, Gastal ao falar em turismo se refere "àquelas pessoas que saem das suas rotinas espaciais e temporais por um período de tempo determinado" e acrescenta, inclusive, "mesmo aquelas pessoas que, morando numa grande cidade, num determinado bairro, aproveitam o fim de semana para buscar outros espaços nessa mesma cidade (...) também serão consideradas turistas" (2005, p.12). Mesmo fazendo críticas a essa visão da autora, quanto à espacialidade do turismo, a viagem continua sendo a principal característica do turismo.

Knafou e Gastal apontam essa dificuldade em caracterizar o turismo, seja pelo uso da linguagem, seja por sua aplicação prática. $\mathrm{O}$ turismo tem, necessariamente, que se referir a deslocamentos em grandes distâncias? O turismo pode ser caracterizado simplesmente pela busca do exótico, do diferente? Gastal (2005) explica seu conceito, colocando que em geral, tanto quem sai do seu país quanto quem sai do seu bairro, busca a presença do “estranhamento, do prazer e de uma certa ansiedade diante do desconhecido e do novo", além da presença de imagens e imaginários.

Knafou (2001) aponta que persiste essa dificuldade, haja vista considerar que todos podem ser turistas, pois não se é turista totalmente e sim, em um dado momento se está turista. Por isso, todos podem ter um ponto de vista sobre o mesmo, visto que todos de alguma forma experimentaram ou vão experimentar o que é ser turista. Assim afirma: 
O turismo é uma atividade humana que, por excelência, proporciona muitas ideias prontas, frequentemente falsas; julgamentos sumários, até mesmo de "cientistas" que entendem possuir uma ideia sobre a questão, já que em certas ocasiões também são turistas (KNAFOU, 2001, p.62).

Cruz (2007) analisa essa questão do ponto de vista da ambiguidade que apresenta: o próprio conceito de turismo. O conceito de turismo esteve sempre relacionado ao lazer, todavia, hoje está impregnado do que Yázigi chama de "turismo obrigatório": turismo religioso, turismo de saúde, etc. Nesse caso, a espontaneidade para a viagem é "nula ou quase nula", segundo a autora. Além disso, como já apontaram outros autores, o conceito de turismo vem se aproximando do conceito de viagem, o que remete a pensar o turismo como "qualquer" tipo de deslocamento.

É o que se percebe no conceito de turismo dado pela OMT (2001) :

O turismo compreende as atividades que realizam as pessoas durante suas viagens e estadas em lugares diferentes ao seu entorno habitual, por um período consecutivo inferior a um ano, com finalidade de lazer, negócios ou outros (CRUZ, 2007, p.4).

Assim, se inflam os dados estatísticos com os números de viajantes mundo afora. Não se tem em conta a real motivação para a saída do viajante de seu local de residência, no entanto se considera os dados numéricos de passageiros nas estatísticas sobre turismo. Os estudos levando em consideração somente os dados estatísticos não dão a real amplitude do turismo na sua dimensão qualitativa, pois estão “ofuscadas pelos números" (CRUZ, 2007. p.4).

Nesse sentido, concordamos com Cruz que, numa aproximação do turismo com a Geografia, principalmente considerando seu objeto de estudo, quando afirma que o turismo tem como principal elemento de consumo o espaço que é transformado em mercadoria e entra no circuito de troca capitalista, entende ser a produção do espaço "um conceito revelador porque diz respeito a um processo revelador". Para justificar sua escolha metodológica afirma, ainda, que 
Não há produção do espaço que:

- Não remeta a uma divisão territorial do trabalho.

- Não requeira uma análise sobre sujeitos sociais envolvidos.

- Não diga respeito a ambas as dimensões do espaço geográfico, ou seja, às suas dimensões materiais e imateriais.

- Não seja social e histórica (CRUZ, 2007, p. 14).

\subsubsection{Turismo e produção do espaço}

A compreensão do fenômeno turístico tem sido alvo de estudos recentes e, de certa forma, objeto de estudo de várias ciências, como a sociologia, a antropologia, a geografia, a história e a economia dentre outras. Os teóricos do turismo têm buscado na filosofia criar as bases epistemológicas desse novo ramo de estudo. Todavia, é apoiada na epistemologia das diversas ciências que os estudos do turismo têm avançado. Dessa forma, podemos afirmar que a compreensão desse fenômeno é muito mais apropriada a um estudo interdisciplinar, pois o turismo envolve uma gama de inter-relações sociais, econômicas e políticas para se realizar.

Segundo Xavier (2007) devido a sua característica espacial, o turismo tem sido objeto de estudo de diversos profissionais, além dos turismólogos. São principalmente, administradores, urbanistas, advogados, historiadores e geógrafos. Para o autor, o turismo tem sido campo de conhecimento para esses e outros profissionais que nele encontram oportunidades e desafios para suas pesquisas, embora permaneça carecendo de aprofundamento, o que abre um campo de estudo ainda a ser conquistado.

A interdisciplinaridade parece ser o caminho para a compreensão do fenômeno turístico. É o próprio Xavier (2007, p. 18), que considera de fundamental importância os estudos que direcionam as pesquisas interdisciplinares.

Algumas áreas de estudo têm objetivos próximos aos do turismo. É o caso da geografia que, assentando-se em uma ótica espacial, incorpora-o como atividade modificadora e organizadora do espaço geográfico (XAVIER, 2007, p. 20). Outros autores também vão afirmar que o turismo, como uma prática social e atividade econômica, é um vetor de produção do espaço (CRUZ, 2007,2009; CARLOS, 2002). 
Trilhando por um viés materialista, Cruz (2009) aponta que uma abordagem geográfica do turismo tem que levar em consideração que essa atividade está envolvida num movimento totalizante dentro do qual se efetivam essas e outras atividades humanas. $\mathrm{O}$ entendimento dessa questão deve levar em consideração que o capitalismo, como um modo de produção de escala mundial, e que se fundamenta em uma divisão social e territorial do trabalho para se realizar, não o faz no sentido da homogeneização, de um desenvolvimento igualitário, e sim na criação de desigualdades, visto que o capital é seletivo, pois nem todos os espaços interessam ao capital, mas somente alguns pontos desse espaço mundial. O capital é seletivo do ponto de vista espacial.

Para Cruz (2009), o pensamento de Milton Santos sobre a produção do espaço converge com os de Lefebvre e de Smith, quando afirma que "não há produção que não seja produção do espaço, não há produção do espaço que se dê sem o trabalho. Viver, para o homem, é produzir espaço" (SANTOS, 2008, p. 96).

O espaço não é apenas o depositário das coisas; ele é, além de produzido pelas relações sociais, produtor dele mesmo. Se existe todo um processo de produção de espaço para o turismo, espaços padronizados, simulacros ou não-lugares, neles se criam e reproduzem relações sociais. Nesse sentido o espaço deve ser percebido como processo, produto e produtor de relações sociais.

Milton Santos (2004) traduz bem essa concepção, pois para ele cada sociedade nas suas relações sociais, dadas pelo trabalho, produzem o espaço, mas ao mesmo tempo são produzidas por estes. O espaço aqui é entendido como espaço social que é produto e produtor de relações sociais.

Para Soja (1993) é possível compreender a diferença do modo de produção capitalista com relação aos modos de produção anteriores quanto à produção do espaço. Para o autor, essa diferença está na produção e reprodução de um desenvolvimento geograficamente desigual, levado a cabo por uma tendência para a homogeneização, à fragmentação e a hierarquização. Estando, portanto, sujeitas aos interesses do capital e de seus meios técnicos de reprodução. Por causa do interesse de acumulação capitalista produzem um espaço dividido e, como qualquer mercadoria, sujeito à venda, seu uso ganha valor de troca. 
Nesse sentido, o espaço é constantemente produzido, à medida que as forças produtivas capitalistas se estabelecem, e reorganizado em vista dos interesses do capital e das novas técnicas surgidas. Harvey (2006) explica que com a introdução do modo de produção de capital, este passa a ser representado na "forma de uma paisagem física, criada à sua própria imagem, criada como valor de uso, acentuando a acumulação progressiva do capital numa escala expansível” (p. 53).

Segundo Cruz (2009), para entendermos a noção de espaço, ao mesmo tempo concreta e abstrata, podemos recorrer a uma definição miltoniana que considera o espaço ser “formado por um conjunto indissociável, solidário e também contraditório, de sistemas de objetos e sistemas de ações, não considerados isoladamente, mas como o quadro único no qual a história se dá" (SANTOS, 2008, p. 106).

Dessa forma, a produção do espaço turístico envolve um complexo de relações e interesses de diversas escalas que devem ser levados em consideração para sua interpretação. "Se a produção do espaço é um processo complexo e conflituoso, entender a participação do turismo nele requer o desvendamento de sua natureza, da sua complexidade e de seus conflitos" (CRUZ, 2007, p.11).

\subsubsection{Turismo e Paisagem}

O turismo praticado na região em estudo envolve um conjunto de elementos que criam no viajante uma perspectiva positiva quanto os aspectos por eles valorizados, tanto objetivamente quanto influenciada pelos agentes de viagem e pela mídia. Isso tudo está presente na paisagem. É a paisagem o objeto de fixação e de percepção primeira desses imaginários $\mathrm{O}$ turismo tem como um de seus atrativos a paisagem. Para a Geografia, a paisagem é uma de suas principais categorias. No entanto, o conceito de paisagem é muito diverso e controverso e leva em consideração uma gama de considerações para a sua constituição tanto física, quanto psicológica.

Segundo uma definição da língua portuguesa, paisagem é tudo aquilo que é perceptível aos olhos, compreendendo um conjunto de elementos em dada porção do planeta. 
Diversos autores utilizam essa argumentação para aprofundarem a discussão. Castro (2002), por exemplo, diz que a paisagem é o que se vê, partindo necessariamente da dimensão do concreto, o que se mostra, acrescida da representação do sujeito, que codifica a observação. A paisagem resultado dessa observação torna-se fruto de um processo cognitivo, mediado pelas representações do imaginário social e de valores simbólicos. Na perspectiva da autora, a paisagem assim concebida, apresenta-se com duas características, sendo ao mesmo tempo real e de representação dos elementos naturais e sociais que a integram.

Martinelli (2001), em referência a outros autores como Bertrand (1978), Santos (1987;1994) e Pichemel (1987), afirma também que a paisagem "é o que vemos diante de nós", sendo, por isso, uma visão de conjunto percebida a partir do espaço que nos envolve. A paisagem é uma forma espacial do presente e, ao mesmo tempo, testemunha de formas passadas que ainda persistem ou não. Para o autor, ela revela, assim, um "dinamismo diacrônico", confirmando a evolução estrutural do processo espacial, demonstrando-nos fases que poderão ser de estabilidade, de reformulação parcial ou de completa remodelação, engendrando novos espaços.

É Santos (2004) que enfatiza a necessidade de se estabelecer uma distinção epistemológica entre paisagem e espaço, pois não são, sequer, sinônimos. Para ele, a paisagem "é um conjunto de formas que, num dado momento, exprime as heranças que representam as sucessivas relações localizadas entre homem e natureza" enquanto o espaço "são essas formas mais a vida que as anima". Lembra o autor que, em geral, a paisagem é apenas uma parte do território perceptível pela visão, é “a história congelada", mas que participa da dinâmica da sociedade. No entanto, é a sociedade que anima as formas espaciais, dando-lhe um sentido, um conteúdo e só ela tem o poder de tudo transformar. "O espaço é a síntese, sempre provisória, entre o conteúdo social e as formas espaciais", completa ele (SANTOS, 2004, p. 109).

O turista se apropria da paisagem, pois a tem como um objeto de desejo, tornada assim pela mitificação do lugar e por sua midiatização. Portanto, deve estar ao alcance dos olhos e por isso se fazem passeios, excursões em viagens. Martinelli (2001b) explica que, nesse sentido, a paisagem sempre será, por excelência, uma visão lateral, ou seja, aquela vista do chão em direção ao horizonte. Importa reter as silhuetas da sucessão em profundidade dos planos verticais que a compõem. O jogo destes planos pode organizar a apreciação da paisagem numa sequência de escalas que vão diminuindo em direção ao horizonte, ao mesmo 
tempo que interpõem requadros que podem encobrir parte dela, que fica atrás. A fotografia entra nesse processo como um auxiliar da memória. Como afirma outro autor: "Turista e fotografia compõem uma dupla inseparável” (GASTAL, 2005, p. 35).

Martinelli (2001) argumenta ainda sobre o assunto:

A paisagem, não só de conteúdo natural, mas também dotada de vida humana, ganha, desta feita, grande destaque no mundo das imagens do turismo. Torna-se recurso. É vendida com forte dose de fantasia. Negocia-se o verde da floresta, o cume da montanha, o por do sol dourado, a praia ensolarada com o mar azul engastado por coqueiros, a praça emoldurada por casas coloniais e sua majestosa igreja. Esse imaginário, quanto mais distante de nós, mais exótico se torna. Exerce maior encanto, mistério e estímulo. Cada cultura, no entanto, enaltece seu arquétipo (p. 152).

\subsubsection{Imagem e imaginário}

É difícil pensar em viagens sem pensar no que leva uma pessoa a optar por este ou aquele meio de transporte, este ou aquele lugar como destino. Não é somente o preço que está em jogo, mas também outros aspectos, mais ligados à motivação que, estimulada por diversos meios como informações de amigos ou a mídia, por exemplo, cria imagens e desejos.

Para Gastal (2005), não se pode pensar que é a imagem que produz o imaginário, pois ao contrário, é a existência de um imaginário que determina a existência de um conjunto de imagens, referindo-se a todo tipo de imagem, sejam cinematográficas, pictóricas, esculturais, tecnológica, etc.

Gastal explica o imaginário como um processo. Para ela:

Há um imaginário parisiense que gera uma forma particular de pensar a arquitetura, os jardins públicos, a decoração das casas, a arrumação dos restaurantes, etc. O imaginário de Paris faz Paris ser o que é. Isso é uma construção histórica, mas também o resultado de uma atmosfera e, por isso mesmo, uma aura que continua a produzir novas imagens (2005, p. 56). 
Aliás, sobre imagem e imaginário, Martinelli (2001) coloca que toda imagem é produzida por um autor, seja uma pessoa ou grupo de pessoas, produzindo-a em determinadas circunstâncias sociais e culturais. A imagem possui a capacidade de chamar a atenção, causar uma impressão e/ou comunicar uma informação. Para o autor "o ato de concebê-la e difundila se inscreve numa situação de comunicação socialmente determinada: a sua grande legibilidade" (p. 151).

Dessa forma, a imagem conduz uma mensagem que depende de sua composição e da interpretação daqueles a quem se dirige, do seu sentido conotativo, possuindo, frequentemente, um valor metonímico. Para Martinelli (2001), a imagem fraciona o mundo, mas a nossa imaginação é capaz de completá-la.

Podemos afirmar, como faz Gastal (2005), que viagens e imaginários caminham juntos, sendo, por isso, importantes na compreensão do turismo. Aventurar-se pelo desconhecido, buscar o que é novo, estimula as pessoas, motivando-as a se deslocar. É por isso que os lugares distantes, ainda não desbravados, desconhecidos, ganham sentido nos sentimentos daqueles que o vislumbram, renovando-se a cada ciclo da história, pois a cada momento novos espaços são criados e novas imagens povoam as mentes das pessoas e novos desejos são estimulados. Como diz Martinelli (2001), o simbolismo da imagem, que emerge do inconsciente, oferece um mundo de possibilidades para o imaginário e em busca dessa paisagem, viaja-se.

Urry (1996) fala de um "sistema de ilusões" gerados pelos diferentes olhares dos turistas e levado a cabo pelos anúncios e pela mídia. Esse é um sistema fechado, mas que se autoperpetua, possibilitando ao turista rever e avaliar os lugares potenciais para novas visitas.

Por fim, para Gastal (2005),

Em termos de imaginário, não há verdade ou mentira, pois todo imaginário é. Ele é invenção, narrativa, seleção, bricolagem, modo de ser no mundo. No imaginário, em consequência, não há verdadeiro nem falso. Como num romance, todos os enredos são possíveis e legítimos. Ou seja, como o sentimento, que sempre é, o imaginário, do mesmo modo, sempre é (p. 75).

Essas características são bem visíveis quando se pensa na Amazônia ou mesmo no Festival Folclórico e a disputa entre os Bumbás de Parintins. São ricas as informações 
produzidas pela mídia, mas também, já existe uma imagem sobre esses atrativos associada a diversas outras visões existentes sobre os mesmos.

\subsubsection{Lugar, território e região}

Três outros conceitos comuns à Geografia são bastante utilizados quando se fala em turismo: lugar, território e região.

O lugar é o mundo em escala. O lugar não é a parte, é o mundo em dimensão. Nele se manifestam os fenômenos, nele o mundo se realiza. O lugar se concretiza também pelo sentido que a sociedade dá aquele espaço. Espaço da cultura, dos sentimentos, do vivido.

Armando Corrêa da Silva (1986) ao falar sobre as categorias em Geografia enumeraas: espaço, lugar, área, região, território, habitat, paisagem e população, entre outros. Sendo que o espaço é o mais geral e que engloba todos os outros.

Entre os que interessam a esse trabalho, a categoria lugar, segundo o mesmo autor, denota o espaço como um complexo de relações que se dão em uma localização definida. Já a categoria território, é onde o lugar se torna real, concreto, lócus da existência do Estado. Depois da categoria território vem a de região, pois se trata de um território já ocupado, com uma organização do espaço e de um modo de vida bem definido (SILVA, 1986, p. 30).

O turismo se manifesta no lugar, no território, na região. Para Carlos (1999), o lugar é produto das relações humanas, entre homem e natureza, tecido por relações sociais que se realizam no plano do vivido, o que garante a construção de uma rede de significados e sentidos que são tecidos pela história e cultura civilizadora produzindo a identidade. Aí o homem se reconhece porque aí vive. O sujeito pertence ao lugar como este a ele, pois a produção do lugar se liga indissociavelmente à produção da vida. Para ela, é no lugar que emerge a vida, sintetizando-o como a "unidade da vida social”. É nesse espaço concreto e real que cada um se localiza, se identifica ou não, usufrui e modifica, visto que o lugar "tem usos e sentidos em si. Tem a dimensão da vida" (CARLOS, 1999, p. 28).

Partindo do pressuposto de Silva (1986), já citado, podemos concluir que o território, essa parcela do espaço, está sempre associado ao domínio e o poder exercido sobre um espaço 
limitado. Logo, é um espaço definido político e administrativamente por um povo. Suas raízes estão na possibilidade de domínio e controle sobre o mesmo pelo Estado.

A respeito do território, Claude Raffestin (1993) foi um dos principais estudiosos dessa temática geográfica, destacando-a dentro de uma ótica que considera o caráter político do território, entendendo-o, também, como um substrato do espaço, este antecedendo ao primeiro. Nas palavras de Reffestin:

É essencial compreender bem que o espaço é anterior ao território. O território se forma a partir do espaço, é o resultado de uma ação conduzida por um ator sintagmático (ator que realiza um programa) em qualquer nível. Ao se apropriar de um espaço, concreta ou abstratamente (...) o ator "territorializa" o espaço. (1993, p. 143).

Quando o autor refere-se à territorialidade do espaço, o faz no sentido da apropriação concreta e abstrata, remete ao entendimento do território como um espaço resultado do trabalho humano, seja objeto ou ideia, e dessa forma revela relações marcadas pelo poder. Nesse sentido, para o autor, o território se manifesta no espaço, mas não pode ser confundido com ele, e sim uma produção a partir do espaço e, para realizá-la, envolve muitas relações, implicando relações de poder (RAFFESTIN, 1993).

Roberto Lobato Corrêa (2002) explica a territorialidade referindo-se às manifestações simbólicas ou materiais com o intuito de se apropriar e manter o território por um determinado agente social, que pode ser o Estado, os diferentes grupos sociais e empresas.

É nesse sentido, como já foi frisado, que podemos concordar com Cruz (2003) para quem, toda a análise que se faça sobre a produção de espaço a partir do turismo, ou ainda, da criação de territórios turísticos, deve levar em conta o conjunto de relações que se estabelecem nessa atividade, sem esquecer a sua dimensão global e local. Nessa imensa teia de relações, o turismo representa apenas uma parte (CRUZ, 2003, p.12).

A identificação de um lugar turístico implica sempre o reconhecimento do espaço e do território. Como afirma Cruz (2003), o turismo enquanto uma prática sócio-espacial vai se apropriando de determinados espaços, transformando-os e, a partir disso, produzindo 
territórios e territorialidades, turistificando os lugares. É a autora quem acrescenta: "Se a produção do espaço é um processo complexo e conflituoso, entender a participação do turismo nele requer o desvendamento de sua natureza, da sua complexidade e de seus conflitos" (CRUZ, 2007, p.11). Essa é uma concepção que vai nortear o desenvolvimento deste trabalho.

Um outro conceito caro a ciência geográfica, mas que é utilizado por outras ciências, principalmente a Economia, é o de região. Apesar de essa discussão não ser nova, sempre há uma certa insegurança na sua definição e no seu uso. Corrêa (1997), em suas discussões sobre região e organização espacial, coloca a região como um conceito-chave para os geógrafos e não-geógrafos quando se referem à questão espacial. Ele esclarece que a região, genericamente, tem referência a lugares que se diferenciam um dos outros. No entanto, o conceito de região desenvolvido pelos geógrafos ao longo de sua história constitui respostas aos múltiplos ângulos com que eles observaram e observavam o mundo real, já bastante fragmentado e articulado. Com a globalização, este processo de exercer muitos olhares sobre o espaço do homem foi acentuado. E ressalta: "A região, esta particularidade dinâmica, continua a desafiar os geógrafos em sua tarefa de tornar inteligível a ação humana no tempo e no espaço" (CORRÊEA, 1997).

Apesar dessa complexidade no estudo da região, a expressão é empregada de diversas formas no cotidiano e no senso comum, referindo-se, geralmente, a um lugar com características comuns ou particulares. O exemplo da Região da Valéria, em Parintins, se assemelha a essa concepção, visto não haver um estudo detalhado que a defina como tal. Todavia, na Amazônia, é comum referir-se a lugares mais distantes, que englobam diversas comunidades e possuem alguma especialização, como "região".

\subsubsection{O turismo mundial: crises e viagens}

O turismo continua a despertar grande interesse por parte dos grandes investidores visto mobilizar um grande fluxo de dinheiro ao redor do mundo. A sua compreensão, todavia, ainda é muito complexa, pois envolve uma multiplicidade de atores e ações que precisam ser bem entendidas. $\mathrm{O}$ importante, neste momento, é reconhecer que é uma atividade econômica, que engloba uma variada rede de agentes sociais, empresas e o próprio Estado para sua plena 
realização. Sem falar que a sua realização propicia ao capital interno e externo uma possibilidade de maximização do lucro. O objeto de desejo para o turismo é uma mercadoria especial, o espaço, que transformado em objeto de consumo e uso, é apropriado pelo capital para o seu próprio proveito.

De acordo com a OMT (World Tourism Organization, UNWTO, 2012), o desembarque turístico internacional cresceu a uma taxa de $5 \%$ em todo o mundo, somente nos primeiros quatro meses de 2012, consolidando a tendência de crescimento que começou em 2010. Para todo o ano de 2012 as previsões esperadas eram de 3\% a 4\% de chegadas internacionais. O número de desembarques internacionais deve chegar a um bilhão em 2012 só para os primeiros três meses do ano (OMT, 2012).

Segundo o mesmo documento, ao longo das últimas seis décadas, o turismo tem experimentado contínua expansão e diversificação, tornando-se um dos maiores setores e de mais rápido crescimento econômico em todo o mundo. Além disso, muitos destinos novos surgiram, desafiando os destinos tradicionais da Europa e América do Norte.

Assim como qualquer atividade econômica está sujeita aos ciclos de crise econômica, sejam elas locais ou mundiais. A população de um país em crise tende a viajar menos que aquelas de países em franca prosperidade, principalmente se nos referimos àquelas que realmente sofrem os abalos desses problemas, geralmente os da classe média.

Apesar de choques ocasionais, as chegadas de turistas internacionais têm mostrado um crescimento praticamente ininterrupto: de 277 milhões em 1980 para 528 milhões em 1995, e 983 milhões em 2011. O gráfico da figura 1 apresenta esse crescimento, com uma pequena variação entre 2001-2002 e da crise recente iniciada em meados de 2008. Neste ano, houve um crescimento de apenas $2 \%$ em relação ao ano de 2007.

As perspectivas de longo prazo e avaliação das tendências futuras, realizadas pela OMT, apontam um aumento no número de chegadas de turistas internacionais em todo o mundo de 3,3\% ao ano em média de 2010 a 2030, o que representa um acréscimo de cerca de 43 milhões de chegadas internacionais a cada ano, atingindo um total de 1,8 bilhão de desembarques em 2030 (OMT, 2012).

Ainda, segundo o documento da OMT, considerando o turismo um serviço comercializado internacionalmente, tornou-se uma das mais importantes categorias comerciais do mundo. Ao longo do tempo, um número crescente de destinos foram abertos e investiu-se no desenvolvimento da atividade turística, transformando o turismo moderno em 
um motor fundamental do progresso socioeconômico através de receitas de exportação, a criação de empregos e empresas, e o desenvolvimento de infraestrutura (OMT, 2012).

Figura 1: Desembarques e receitas internacionais do turismo 1990-2011

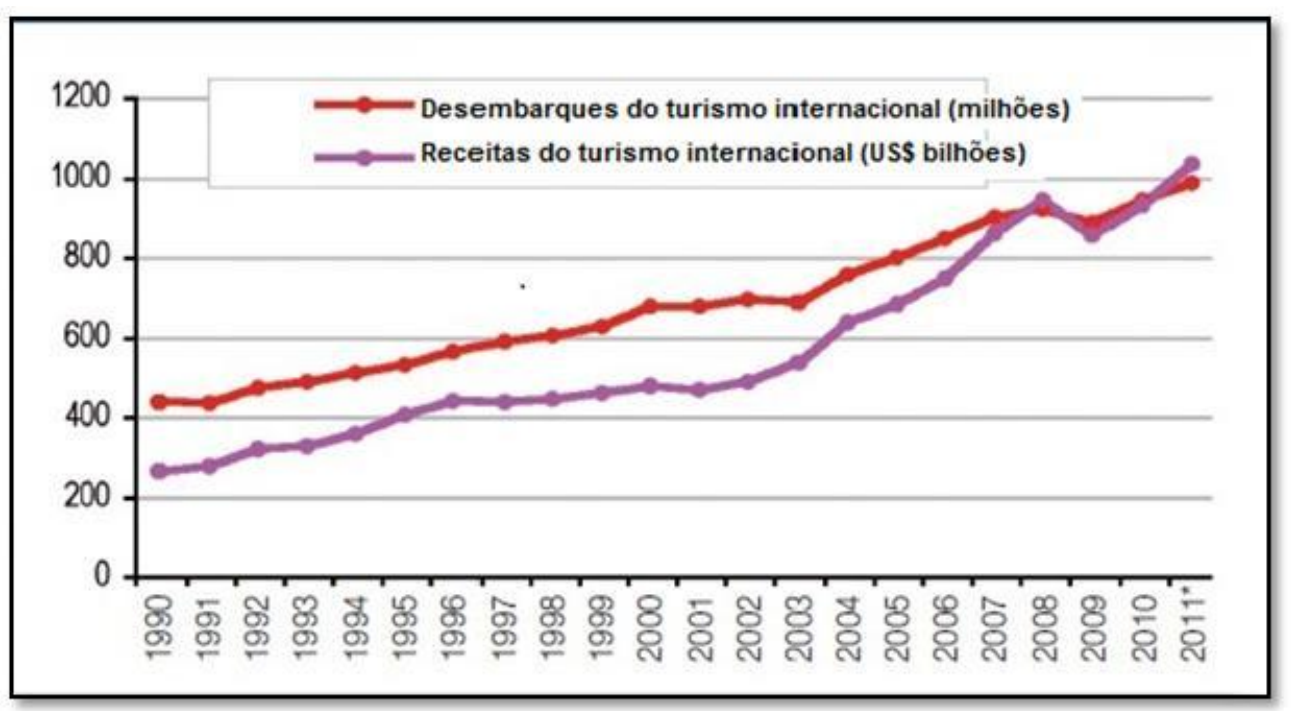

Fonte: Organização Mundial do Turismo (OMT), 2012.

Em 2011, a receita de exportação global gerada pelo turismo receptivo, incluindo transporte de passageiros, ultrapassou US\$ 1,2 trilhão (figura 1), ou 3,4 bilhões de dólares / dia, em média. Globalmente, como uma categoria de exportação, o turismo ocupa a quarta posição depois de combustíveis, produtos químicos e alimentos As exportações ligadas ao turismo respondem por até $30 \%$ das exportações mundiais de serviços comerciais e de $6 \%$ do total das exportações de bens e serviços. Para muitos países em desenvolvimento, é uma das principais fontes de renda de câmbio e o número um da categoria de exportação, criando emprego muito necessário e oportunidades de desenvolvimento, segundo a OMT (2012).

Como hoje se sabe que as pessoas estão viajando cada vez mais, o que é reflexo do crescimento da renda justamente entre as populações da classe média, ou classe "C", como aqui no Brasil, é possível avaliar que uma crise de desemprego ou de desvalorização da moeda nacional pode frear o desejo de se viajar, principalmente para o exterior.

Assim, as crises, ditas mundiais (figura 2), podem acarretar uma redução nos deslocamentos internacionais, todavia, essas crises atingem os países diferentemente. $\mathrm{Na}$ atual crise, que se prolonga desde 2008, enquanto moradores de países da Europa e da America do Norte viajam menos, chineses, brasileiros e russos aproveitaram para viajar e sair às compras. 
Figura 2 - Chegadas e receitas do turismo internacional no Mundo (1990-2012)

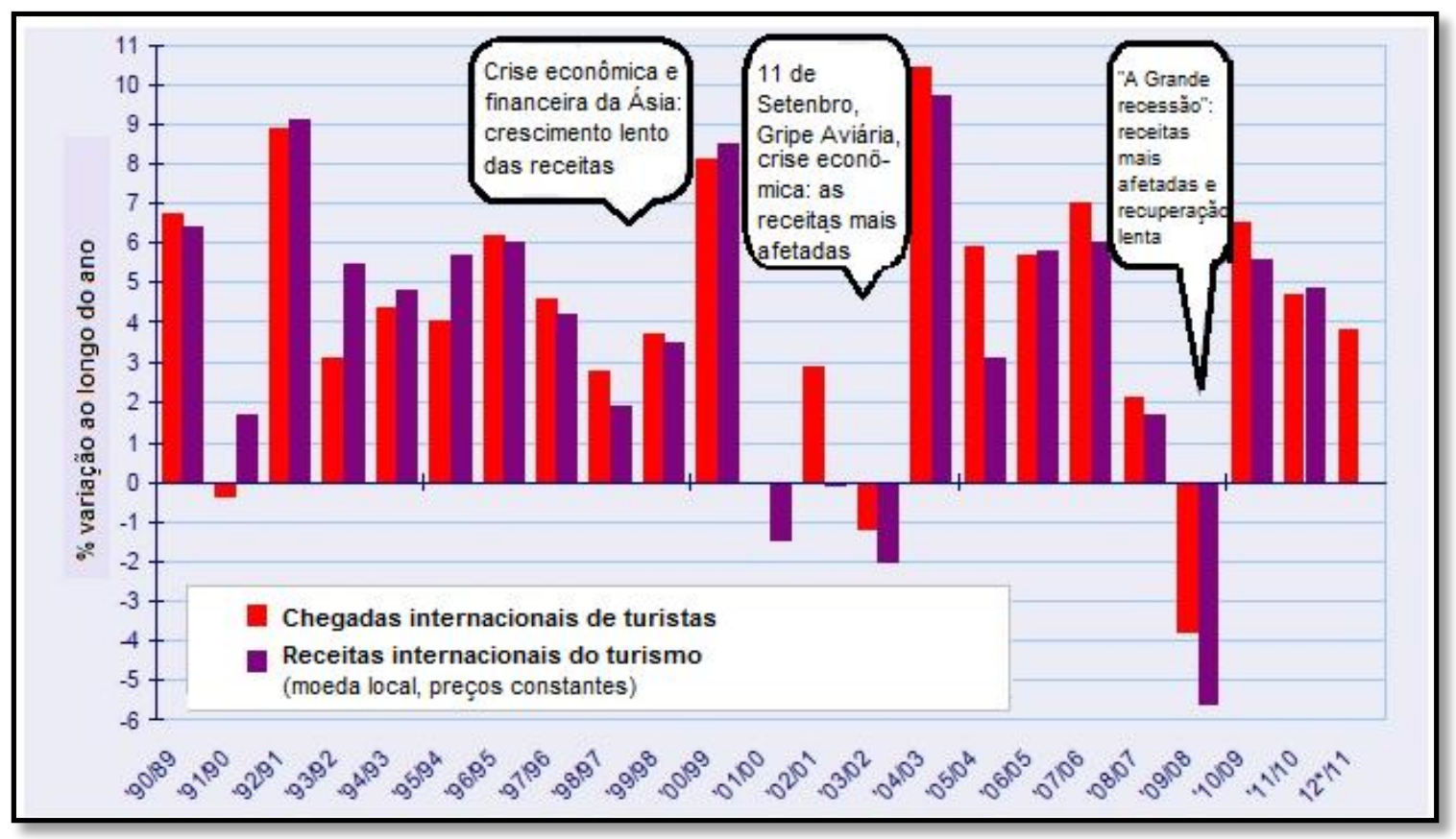

Fonte: adaptado de OMT, 2013

No gráfico acima se percebem os efeitos das grandes crises mundiais nos deslocamentos dos turistas a nível internacional, a variação percentual mostra que o crescimento das receitas tem acompanhado de perto o crescimento de chegadas de turistas no pós-crise. Apesar de não termos saído totalmente da crise atual a OMT calcula que mais de 1 bilhão de chegadas de turistas aconteceram em 2012, um recorde (OMT, 2013).

Além disso, a OMT acaba de divulgar que a China é o número um de gastos com o turismo em 2012. Os turistas chineses gastaram 204 bilhões de dólares em viagens pelo mundo, superando todos os demais países. Essas despesas no exterior representa um crescimento de $40 \%$ em relação a 2011. Houve um crescimento significativo de número de viagens internacionais de cerca de 10 milhões em 2000 para mais de 83 milhões em 2012. Ao nível de comparação:

Em 2005, a China ficou em sétimo no quesito despesas com turismo internacional e, desde então, foi passando aos poucos países como Itália, Japão, França e Reino Unido. No ano passado [2012], ganhou o primeiro posto e ultrapassou Alemanha e os Estados Unidos, que gastaram cerca de R \$ 168 bilhões em viagens (Jornal do Brasil, 07/04/2013, internacional: www.jb.com.br). 
É preciso lembrar que o turismo tem sido um dos meios para a expansão capitalista que nas últimas décadas tem tido abundância de dinheiro, excedentes de capital precisam ser investidos em atividades produtivas. É Harvey quem coloca alguma luz sobre o assunto ao afirmar que:

A produção de espaços e lugares absorveu, ao longo do tempo, grandes quantidades de excedentes de capital. Novas paisagens e novas geografias foram criadas dentro das quais o capital circula em formas que são frequentemente assombradas por profundas contradições (2011, p. 77).

O turismo, com sua capacidade de mobilizar pessoas e recursos pelo mundo, é um grande direcionador de fluxo de dinheiro para os países de economias avançadas. Países da Europa e os Estados Unidos continuam sendo os principais destinos de turistas em todo o mundo. A França continua como o primeiro país em desembarque de turistas internacionais, seguido dos Estados Unidos e da China que avança a cada ano como opção de viagem. As receitas relacionadas ao turismo são maiores nos Estados Unidos, o primeiro do ranking, seguidos pela Espanha e França. A China vem logo a seguir, na $4^{a}$ colocação (Tabela 1).

Tabela 1- Ranking dos países receptivos quanto a desembarques de turistas e receitas

$$
2010-2011
$$

\begin{tabular}{|c|c|c|c|c|c|c|c|c|c|}
\hline \multirow{3}{*}{ Ranking } & \multicolumn{4}{|c|}{$\begin{array}{c}\text { Desembarques internacional de } \\
\text { turistas }\end{array}$} & \multirow{3}{*}{ Ranking } & \multicolumn{4}{|c|}{$\begin{array}{l}\text { Receitas do turismo } \\
\text { internacional }\end{array}$} \\
\hline & \multicolumn{2}{|c|}{ Milhões } & \multicolumn{2}{|c|}{ Cresc. (\%) } & & \multicolumn{2}{|c|}{ Bilhões } & \multicolumn{2}{|c|}{ Cresc. (\%) } \\
\hline & 2010 & 2011 & 2010 & 2011 & & 2010 & 2011 & 2010 & 2011 \\
\hline 1. França & 77,1 & 79,5 & $\overline{0,5}$ & $\overline{3,0}$ & 1. Estados Unidos & 103,5 & 116,3 & $\overline{9,9}$ & 12,3 \\
\hline $\begin{array}{l}\text { 2. Estados } \\
\text { Unidos }\end{array}$ & 58,8 & 62,3 & 8,8 & 4,2 & 2. Espanha & 52,5 & 59,9 & $-1,2$ & 14,0 \\
\hline \multicolumn{10}{|l|}{ Continuação } \\
\hline 3. China & 55,7 & 57,6 & 9,4 & 3,4 & 3. França & 46,6 & 53,8 & $-6,0$ & 15,6 \\
\hline 4. Espanha & 52,7 & 56,7 & 1,0 & 7,6 & 4. China & 45,8 & 48,5 & 15,5 & 5,8 \\
\hline 5. Itália & 43,6 & 46,1 & 0,9 & 5,7 & 5. Itália & 38,8 & 43,0 & $-3,6$ & 10,9 \\
\hline 6. Turquia & 27,0 & 29,3 & 5,9 & 8,7 & 6. Alemanha & 34,7 & 38,8 & 0,1 & 12,0 \\
\hline 7. Reino & 28,3 & 29,2 & 0,4 & 3,2 & 7. Reino Unido & 32,4 & 35,9 & 7,5 & 10,9 \\
\hline
\end{tabular}




\begin{tabular}{|c|c|c|c|c|c|c|c|c|c|}
\hline Unido & & & & & & & & & \\
\hline 8. Alemanha & 26,9 & 28,4 & 10,9 & 5,5 & 8. Austrália & 29,8 & 31,4 & 17,4 & 5,5 \\
\hline 9. Malásia & 24,6 & 24,7 & 3,9 & 0,6 & 9. Macau (China) & 27,8 & $\ldots$ & 53,5 & $\ldots$ \\
\hline 10. México & 23,3 & 23,4 & 4,2 & 0,5 & $\begin{array}{l}\text { 10. Hong Kong } \\
\text { (China) }\end{array}$ & 22,2 & 27,7 & 35,6 & 24,7 \\
\hline
\end{tabular}

Fonte: adaptado de OMT, 2012

\subsubsection{Turismo no Brasil: emergência e planejamento}

O Brasil aparece como o $8^{\circ}$ país em gastos com o turismo, segundo a OMT (2012). O país foi um dos mercados emissores que mais cresceu em 2011, com um aumento de 30\% nas despesas, atualmente terceira posição nas Américas.

Dos BRICs, os países emergentes, o Brasil teve um acréscimo em suas despesas de US\$ 5 bilhões, chegando aos US\$ 21 bilhões de gastos, em 2012, isso após um aumento de $51 \%$ em 2010 , saindo do $18^{\circ}$ lugar para a $12^{\mathrm{a}}$ posição entre os países que mais gastam com o turismo (OMT, 2012).

No entanto, o país ainda recebe muito poucos turistas, se considerada sua imensa diversidade de recursos naturais, culturais e históricos. Dos cerca de 1 bilhão de turistas que circulam pelo mundo, somente 5,5 milhões deles passam pelo Brasil, ou seja, 0,6\% do turismo mundial (2011).

As Políticas voltadas para o turismo têm a responsabilidade de tornar o país mais atrativo turisticamente, para atrair parcela cada vez maior desse "bolo", considerando o turismo como um importante gerador de riquezas e divisas para o país.

O governo do presidente Luis Inácio Lula da Silva (2003-2006 e 2007-2010) foi importante para o desenvolvimento do setor no país. Com a criação do Ministério do Turismo (MTur), diferentemente dos governos anteriores no qual o turismo estava ligado a uma outra pasta, ganha destaque e independência na estrutura desse governo. Essa iniciativa é uma resposta a antigas demandas deste setor e demonstra a posição do governo em relação a uma nova concepção que leva em consideração a geração de empregos e divisas através do desenvolvimento do turismo. O Ministério ficou responsável pela elaboração da política nacional de desenvolvimento do turismo, a promoção e divulgação do turismo nacional, no 
país e no exterior, a criação de estímulos às iniciativas públicas e privadas, com a captação de investimentos para as atividades turísticas e, finalmente, pelo planejamento, coordenação, supervisão e avaliação dos planos e programas de incentivo ao turismo.

Coube ao MTur a elaboração do Plano Nacional do Turismo (PNT), um instrumento de planejamento que tem como finalidade explicitar o pensamento do governo e do setor produtivo e orientar as ações necessárias para consolidar o desenvolvimento do turismo no país. O plano, que entrou em vigor em abril de 2003, foi elaborado com a participação de entidades, instituições e empresas que atuam no segmento turístico e também teve a contribuição de secretários e dirigentes estaduais e presidentes de empresas públicas deste setor.

Enquanto estratégia governamental, o PNT 2003-2007 estabelecia os objetivos do plano em relação à melhora dos indicadores econômicos e sociais e da sua importante contribuição para a redução das desigualdades regionais.

Através das ações propostas pelo Plano Nacional do Turismo, o governo pretendeu criar condições para gerar 1,2 milhões de novos empregos e ocupações no turismo, o que geraria investimentos na economia de aproximadamente 12 bilhões de reais até 2007. A pretensão do governo era ampliar a oferta turística brasileira, desenvolvendo no mínimo três produtos de qualidade em cada estado da federação e distrito federal, o que significaria cerca de 80 novas destinações.

Essas metas eram ambiciosas para o momento, visto o mundo estar entrando no século XXI ainda abalado pela crise econômica de 1998 com seu epicentro na Ásia e, em seguida, as ações terroristas de 11 de Setembro e a SARS que abalaram o mundo e o turismo, em particular. Vale lembrar que, a melhoria nos números referente ao turismo no Brasil, pode ou não ser resultado de um desenvolvimento do turismo feito de forma eficaz, de forma sustentável, econômica, social e ambiental, pois o crescimento do turismo não significa necessariamente que a atividade esteja gerando benefícios onde ela está acontecendo, nem de maneira uniforme. Pela nossa experiência, pode-se concluir que muitos desses resultados são obtidos sem o devido envolvimento da população local, mesmo quando algumas oportunidades de emprego e renda são criadas, pois, não participam da distribuição dos benefícios do turismo e ainda têm que arcar com os impactos negativos decorrentes de falhas ou da ausência de planejamento. 
Em 1999, segundo dados da Empresa Brasileira de Turismo (Embratur), entraram no país 5.107.169 turistas que gastaram cerca de US\$ 4 bilhões. Nesse ano o Brasil estava em $39^{\circ}$ lugar dos destinos turísticos mundiais, segundo a OMT (CASEMIRO FILHO, 2002)

Concordamos que o turismo deve ser planejado, buscando encontrar equilíbrio entre a eficiência do crescimento econômico, igualdade na distribuição social dos recursos e respeito às limitações ambientais. Esta não é uma tarefa fácil, pois envolve uma integração entre diversos setores, interesses antagônicos que geram conflitos e ainda exige pessoas e instituições, ao nível local, regional e nacional, que saibam superar e contornar essas crises e viabilizar projetos que realmente atendam os interesses comerciais, mas, sobretudo, viabilizem o envolvimento e a participação, tanto na elaboração como nos resultados, da população local nos destinos do turismo.

A criação do Ministério do Turismo e os Planos Nacionais de Turismo são conquistas muito importantes que sem dúvida representam um grande passo, mas que ainda precisa ser acompanhado por uma longa discussão sobre que turismo se quer e de que forma cada região pode alcançá-lo.

O PNT 2007-2010, dando sequência ao plano anterior, ainda com objetivos ligados a melhoria das condições gerais que viabilizem a expansão do turismo, tanto receptivo quanto interno, propõe agora o Turismo de Inclusão. Vislumbrando a melhoria das condições gerais da população brasileira, a prioridade volta-se para o mercado interno do turismo, na perspectiva de melhorar o fluxo de turistas nacionais.

Segundo o documento, nesse período (2007-2010) o objetivo era melhorar a infraestrutura do turismo nacional, definindo e preparando os 65 destinos turísticos, distribuídos por todo o território nacional, dentro dos padrões mundiais de qualidade para, assim, alcançar uma marca histórica de 217 milhões de viagens no mercado interno. Isso tudo geraria 1,7 milhão de empregos e US\$ 7,7 bilhões em divisas para o Brasil. Aqui a argumentação era a de que o turismo brasileiro poderia ampliar a oferta de produtos tanto para consumidores de baixa renda, quanto para a classe média e para o turista de renda alta.

O PNT preconiza a necessidade de o turismo cumprir sua função social, com a inclusão de parcela cada vez maior da população no turismo, além de, inclusão de novos destinos, inclusão de novos segmentos de turistas, inclusão de mais turistas estrangeiros, inclusão de mais divisas para o Brasil, inclusão de novos investimentos, inclusão de novas oportunidades de qualificação profissional, inclusão de novos postos de trabalho para o 
brasileiro. Segundo as diretrizes apresentadas, "inclusão para reduzir as desigualdades regionais e para fazer do Brasil um país de todos" (PNT, 2007).

\subsubsection{Plano Nacional de Municipalização do Turismo (PNMT)}

O PNMT foi desenvolvido e coordenado pela EMBRATUR ainda na década de 1990, com o objetivo de implementar um modelo de gestão descentralizada da atividade turística. Além disso, almejava ainda a conscientização, sensibilização, estímulo e capacitação dos agentes de desenvolvimento que compõem a estrutura do turismo no município, tendo como fim a participação da comunidade nas decisões, fazendo com que reconhecessem o turismo como um importante instrumento para o desenvolvimento local.

O foco da PNMT estava na descentralização da gestão do turismo e na capacitação dos agentes municipais para desenvolver o turismo local e, por conta disso, o programa objetivava criar ferramentas para o desenvolvimento do turismo, estimulando parcerias e mobilizando a comunidade à gestão da atividade turística.

Dentre seus objetivos gerais merecem destaque: a conscientização do cidadão para a importância do turismo; a descentralização; o poder normatizador, transferindo ao município a competência para equacionar e ordenar soluções locais; a elaboração de instrumentos e métodos que ajudem os municípios a planejar adequadamente a atividade; a formação de parcerias entre o poder público, a iniciativa privada e a sociedade civil organizada na busca de caminhos e respostas; e a otimização na prestação de serviços turísticos de forma a não só operacionalizá-los com qualidade e segurança, mas também divulgar e vender melhor o produto (EMBRATUR, 2001).

Apesar do PNMT impor uma descentralização, o programa estabelece uma estrutura hierarquizada, de modo que, se aceito pelos estados e municípios deve ser seguido de acordo com o que é imposto pelo poder central. O PNMT estabelece no seu ordenamento uma estrutura basicamente hierárquica para a sua implementação. É uma "faca de dois gumes", pois dá aos órgãos, nos três níveis de poder que, teoricamente não possuem uma relação hierárquica político e administrativa entre si, uma possibilidade de independência, sendo que a implementação do programa depende da subordinação dos órgãos às decisões estabelecidas sempre aos níveis de poder superior, ficando o município, o principal executor do programa, o mais dependente. Só assim o programa se viabiliza. 
Segundo Cruz (2003), houve, pelo menos de início, um número pequeno de municípios que aderiram ao PNMT, haja vista que o método adotado, alemão adaptado à realidade nacional segundo seus idealizadores, não foi tão apropriado para o caso brasileiro, fazendo com que poucos municípios conseguissem concretizar os passos para a implementação da municipalização do turismo.

\subsubsection{Turismo para a Amazônia: turismo de natureza e ecoturismo}

Cabe aqui fazer algumas considerações sobre as políticas direcionadas à Amazônia, visto ser essa a maior região do país e ser uma região de grande expressão internacional, principalmente ligada a sua biodiversidade e sua extensa bacia hidrográfica, cortada pelo grande rio Amazonas. Teoricamente um expressivo destino turístico, mas que devido a incipiente infraestrutura e elevados custos de transporte ainda não é o principal destino de turistas internacionais no Brasil. Desde o período do governo militar que a Amazônia é vista como um "lugar das possibilidades", de exploração, de riqueza e de lucro. Os Planos de Desenvolvimento da Amazônia tinha como orientação a integração desse espaço à economia nacional, por meio da instalação de polos de desenvolvimento que irradiariam o desenvolvimento para toda a região. Baseada em incentivos fiscais e financeiros para as empresas, pouco valor deu aos impactos ambientais que poderiam advir com a abertura e pavimentação de estradas e infraestruturas dentro da floresta. Ao mesmo tempo, os militares lançaram o I Plano de Turismo da Amazônia, no mesmo sentido, priorizando a implantação de uma infraestrutura pela iniciativa privada para o turismo. Andrade e Tavares (2011), ao criticar esse modelo, afirmam que a imagem da região ficará mais marcada pela degradação ambiental provocada pela abertura de estradas na floresta que por seus atrativos turísticos. São categóricas em afirmar que a política de integração amazônica da década de 1970 pode ser pensada como um "vetor de estímulo ao turismo na região, mas também como o vetor de uma imagem Amazônica vitrine da degradação ambiental". As autoras caracterizam dois tipos de públicos desse processo: um primeiro atraído pelos negócios da Zona Franca de Manaus de forma majoritária e o segundo, motivada pela descoberta do exotismo da Amazônia. Por conta disso, o modelo de turismo implementado até então, caracteriza-se por uma turistificação totalmente dissociada da presença das populações locais. Da mesma forma, ainda hoje, percebe-se que os lugares turísticos da região ainda funcionam de maneira "mal integrada e 
principalmente que eles dinamizam pouco um espaço bastante limitado da maior floresta brasileira" (ANDRADE; TAVARES, 2011).

Já na década de 1980, a implantação do PNMT na Amazônia, como já vimos, não correspondeu ao desejado pelo governo federal, visto as dificuldades dos municípios para sua implementação.

Um projeto específico para a região, como já foi apontado por outros autores, deve estar ligado ao seu potencial ecológico e a força que tem o apelo à natureza e a sua conservação, principalmente. Desde o começo do século XX já vem se discutindo os impactos que a ação do homem vem provocando aos recursos naturais e os reflexos dessa ação na qualidade de vida da sociedade. Nos anos 1960, movimentos ecológicos preservacionistas apontam a necessidade de se coibir a avanço da sociedade industrial sobre o meio ambiente através de reservas ambientais. Essas reservas estariam longe da ação humana e abertas à contemplação daqueles que quisessem sentir a natureza na sua totalidade. Apesar de aceito por alguns estados, a criação de reservas criou um conflito em uma sociedade que depende, e cada vez mais, dos recursos naturais para a produção e o consumo. Em torno dessa discussão chega-se, em 1972, à I Conferência Mundial sobre Meio Ambiente da ONU, realizada em Estocolmo, onde o documento de referência, produzido pelo Grupo de Roma, denominado Limites do Crescimento, apresentava severamente a necessidade de se encontrar o ponto ótimo para a exploração dos recursos finitos da natureza, sem o qual os danos oriundo dessa ação poderia comprometer a vida no planeta. Estavam colocadas as bases para a crescente discussão sobre os rumos da humanidade sobre esse planeta na sua relação com os grandes ecossistemas e os fragmentos ainda existentes dos recursos naturais. A água saudável já estava atingindo seu limite de oferta e já existem problemas de abastecimento e sede em várias partes do mundo. Fala-se inclusive em mudança de paradigma por conta dessa calorosa discussão. Outros eventos se sucederam como a Rio-92, a II Conferencia Mundial sobre meio ambiente e Desenvolvimento, que abre a discussão sobre um “desenvolvimento sustentável”, conceito esse carregado de ideologia para o lado que o defende sem, contudo, atingir os efeitos desejados nos países e comunidades locais que mais sofrem com os problemas de pobreza e degradação ambiental.

Envolvido nessa atmosfera, o governo brasileiro cria nos anos 1980 a Política Nacional do Meio Ambiente e cria ainda, com a ajuda da sociedade brasileira, um parágrafo todo dedicado ao meio ambiente na Constituição Federal de 1988. 
No tocante ao turismo, o destaque é criado em torno de um turismo ecológico, um turismo sustentável ou um ecoturismo. Tanto é, que em 1994 foram estabelecidas as Diretrizes para uma Política Nacional de Ecoturismo, coordenada pela Embratur. No documento o ecoturismo é tratado como um segmento da atividade turística, capaz de atuar de modo sustentável sobre o patrimônio natural e cultural, inclusive incentivando sua conservação e buscando a formação de uma consciência ambientalista por meio da interpretação do ambiente, levando em consideração o bem estar das populações envolvidas. O governo acreditava que o momento era propício para a implementação do ecoturismo como alternativa sustentável de desenvolvimento, tendo em vista o aproveitamento racional do potencial ambiental dos seus recursos. Os grandes ecossistemas citados no documento são a Amazônia, o Pantanal, o Cerrado, a Caatinga, a Mata Atlântica entre outros.

Dentro do PNMT foi criado um programa destinado exclusivamente a atender o turismo na Amazônia, o PROECOTUR (Programa de Desenvolvimento do Ecoturismo na Amazônia) com o objetivo de desenvolver o ecoturismo de forma sistemática na região. A criação de polos ecoturísticos é um dos mecanismos para viabilizar esse programa, associado a outras ações do PNMT já citadas.

Diferentemente da costa litorânea, onde se explora o turismo "sol e praia", na Amazônia o PROECOTUR tentou viabilizar o ecoturismo, resultando na instalação e dos hotéis de selva. A crítica a esse modelo de turismo está no confinamento dos turistas ao território controlado pelo empreendimento, totalmente distinto da essência do conceito de ecoturismo.

Segundo Cruz (2003), o turismo planejado para a Amazônia, via PROECOTUR, considerando os aspectos peculiares da região, como a extensa rede hidrográfica que lhe serve como via de transporte e a falta de infraestrutura para atender um turismo mais adensado para viabilizar um turismo de massa, faz-se necessário "envolver cidades como nós de uma rede de distribuição dos fluxos turísticos" (p.97).

Cruz (2003) percebe que o ecoturismo na Amazônia tem muito a ver com a valorização do setor turístico dada pelas políticas públicas, com o crescimento do segmento turístico de natureza, com a permanente necessidade de expansão territorial e diversidade do mercado de destinos turísticos, tendo, portanto, muito pouco de natural. Sem falar que o turismo se efetivará na zona rural, o que preocupa a autora pelo contato, muitas vezes "pernicioso" dessas comunidades com uma cultura trazida pelo turista. 
Importante considerar as afirmações de Cruz quando assevera que essa estratégia de desenvolvimento regional criada pelo PROECOTUR

(...) promove a concentração espacial de estruturas e de fluxos de visitantes, aparece não apenas como uma opção do planejamento físico-territorial do turismo; ela é a opção política, orientadora de um planejamento espacial segregador de turistas e residentes (2003, p. 97).

Apesar de passados vários anos depois do lançamento do PNMT e outras ações com vista à melhoria do turismo na região, ainda hoje a atividade carece de maior atenção e de um aprofundamento da discussão sobre o turismo enquanto uma prática social e isso quer dizer um envolvimento da sociedade local nos destinos e gestão do turismo, pois afeta ou afetará a todos onde o turismo se dá. Assim, o planejamento do turismo tem que levar em conta a participação de todos os segmentos envolvidos: poder público, agentes do turismo, empresário, entidades civis organizadas, ONGs e, principalmente, a comunidade interessada.

\subsubsection{Peculiaridades do Turismo no Amazonas}

O estado do Amazonas, o maior estado da federação, apesar de ter reconhecido seu imenso potencial ecoturístico, com boa parte de sua floresta conservada e rica biodiversidade, tendo, inclusive, recebido do Governo Federal o título de "Estado Referência para o Ecoturismo", não tem o ecoturismo como sua principal atividade econômica (BARRONCAS, 2004; FARIA, 2001).

Contudo, o turismo no Amazonas vem crescendo anualmente. Não é de hoje que vem crescendo no imaginário mundial, atraindo turistas que querem conhecer o "último reduto de floresta"; "o maior rio de água doce do mundo"; "a maior biodiversidade do planeta"; e outros novos e antigos mitos que cercam o imaginário da população como o "pulmão do mundo"; "a terra das amazonas", "El dorado" dentre outros.

Essa imagem ainda é vendida pelos responsáveis de divulgar o país mundo afora. São mensagens carregadas de ufanismo e de forte apelo do verde, do ecológico, de proteção do planeta. As terras onde habitam os últimos povos que ainda vivem como selvagens, sem contato com a sociedade dita moderna, ou mesmo, os nativos, indígenas que mantém uma intensa ligação com a floresta. É isso que atrai, em boa medida, os turistas para a região. O 
anúncio realizado para a venda de passagens em transatlânticos que fazem roteiro pelo rio Amazonas e que param na "Boca da Valéria", dão-nos uma dimensão desse imaginário.

\section{Boca da Valeria (Amazon River), Brazil}

Boca da Valeria is a remote village at the confluence of the Rio da Valeria and the Amazon. Approximately 75 people live in this minute village, surrounded by the great rain forest of the Amazon Basin. Life here is a startling contrast to life in Brazil's modern Amazonian cities of Santarem and Manaus. In this tiny fishing village, see firsthand how the people of the Amazon live. Experience their culture as you visit their village. (Site da Princess Cruises: http://www.princess.com/learn/ports/south_america/ ports/BV1.html, em março de 2010)

Nessa mensagem é possível perceber a visão estereotipada de um lugar na Amazônia. Com certeza, o turista espera encontrar um lugar primitivo, com uma população no limite da pré-história. É bem verdade que o lugar fascina devido sua beleza natural e é claro a vida simples do caboclo-ribeirinho da Amazônia. Longe de ser um "índio", a vida nas comunidades amazônicas pode surpreender quem a vê pela primeira vez. Todavia, a Boca da Valéria está longe de ser uma síntese das populações amazônicas como quer o anúncio da empresa de turismo.

\subsubsection{Plano Estadual de Turismo}

O órgão oficial de turismo do Estado é a Empresa Estadual de Turismo, AMAZONASTUR, criada em 2003 com o objetivo de potencializar o turismo local, articulando e participando dos programas a nível nacional e criando políticas em vista ao desenvolvimento do turismo no estado, tendo como parceiro os municípios. Tem ainda responsabilidade de dar apoio ao desenvolvimento sustentável de novos produtos turísticos, além de oferecer condições de aperfeiçoamento aos já existentes e promover o planejamento e execução da política estadual de turismo.

O Plano de Desenvolvimento do Turismo no Amazonas tem aplicação no período de 2008 a 2011, é um instrumento de estruturação e planificação do turismo amazonense para esse período. Além de fazer um levantamento dos pontos fracos e da potencialidade turística, faz estabelecimento de cenários para esse período, apresentado as possibilidades possíveis para o desenvolvimento sustentável do turismo. A "Formulação estratégica", contida no 
documento, é a etapa que direciona objetivamente gestores e empresariado para que maximizem as potencialidades do turismo no Amazonas e superem as ameaças levantadas. Essa formulação deve ser criativa e facilmente acessível a tais atores.

\subsubsection{Ecoturismo, turismo no Amazonas}

$\mathrm{Na}$ Amazônia, e em especial no Amazonas, a prática do ecoturismo tem sido caracterizada pela criação de novas territorialidades (hotéis de selva). Segundo Cruz (2003), na Amazônia o que predomina é a ação-atuação da iniciativa privada, agentes de mercado e planejadores territoriais, nesse caso o próprio Estado, na turistificação dos lugares. Ela não obedece a nenhum planejamento, sendo resultado de "ações espontâneas, isoladas e interesseiras de agentes de mercado" (2003, p. 106).

Para a autora, esse "isolamento territorial de turistas tem como uma de suas principais consequências a supressão da possibilidade de interação entre turistas e população residente" (CRUZ, 2003, p. 113).

Como já foi dito, o ecoturismo é um dos segmentos que mais atrai turistas para a região, porém ele não pode ser praticado de qualquer forma. O turismo praticado pelo diversos empreendimentos na região é denominado como ecoturístico, sendo que, no entanto, trata-se apenas de um turismo "na selva", sem a devida valorização da cultura e diversidade de vida e do meio ambiente. Mesmo com a municipalização, e que os municípios tenham uma estrutura administrativa ligada ao turismo, é preciso instituir normas para o uso do território e fiscalizar o seu cumprimento. Ainda, é preciso que populações tradicionais e a população envolvida sejam os maiores sujeitos nesse contexto, pois devem direcionar o desenvolvimento de atividades ecoturísticas, além de ajudar a fiscalizar os possíveis impactos ao meio ambiente e não permitir a exploração da mão de obra ou subjugar a cultura local.

\subsection{Espaço, turismo e o método}

O método é o caminho a ser seguido para se chegar a um fim. O método científico pode ser explicado como um instrumento intelectual e racional, que na sua caminhada para estabelecer verdades ou fazer uma leitura do mundo, possibilita a apreensão da realidade objetiva pelo investigador (SPOSITO, 2004). 
A história do desenvolvimento da Geografia enquanto ciência, desde meados do século XVIII, mostra o apego dos estudiosos a variados métodos de análise e interpretação da realidade de acordo com o predomínio destes ao longo da sua evolução. A Geografia Tradicional, que vai desde sua fundação como disciplina acadêmica, da sistematização de Humboldt e Ritter até basicamente os anos 1960, tem como fundamento comum o apego ao método positivista. O pensamento positivista diz respeito a todos as correntes não dialéticas, os seus estudos baseiam-se nos aspectos visíveis do real, mensuráveis, palpáveis. Os procedimentos estariam limitados, por conta disso, a observação e de encadeamentos lógicos indutivos para ganhar ar de cientificidade (MORAES, 1993, p. 21-22).

Segundo Moraes (1993), depois dessa fase percebe-se um movimento de renovação da geografia, a partir dos anos 1960, levando a cabo novas definições e novas discussões, fora do contexto do positivismo clássico, é o caso da fenomenologia, o estruturalismo, o neopositivismo e o marxismo.

Sposito (2004), em seu trabalho sobre a Geografia e a Filosofia, faz um debate a cerca das bases metodológicas da geografia a partir da discussão filosófica do conhecimento geográfico. Para o autor, o método deve ser um instrumento intelectual e racional que possibilite ao pesquisador a apreensão da realidade. Apesar de reconhecer a existência de outros métodos, discutidos e abordados por outros autores, Sposito, explicita três deles como influentes na geografia enquanto ciência: o hipotético-dedutivo, o dialético e o fenomenológico.

\subsubsection{O método hipotético-dedutivo}

O método hipotético-dedutivo, segundo o autor, tem suas raízes no pensamento de René Descartes (1596-1650) que estabeleceu algumas regras: a primeira é a evidência que não deve admitir alguma coisa como verdade se não a reconhece como tal. A evidência é algo indubitável e deve resistir à dúvida; a segunda é a análise: dividir cada uma das dificuldades em tantas parcelas quantas for possível; a terceira regra é a da síntese refere-se à capacidade de concluir por ordem seus pensamentos, do mais simples ao mais complexo, lembra o procedimento indutivo; a última regra é aquela dos desmembramentos tão completos... "a ponto de estar certo de nada ter omitido" (SPOSITO, 2004, p.30). 
Autores contemporâneos como Karl Popper (1902-1994) retomam a linhagem cartesiana do método e aprimora a doutrina positivista. Para ele "formular uma definição aceitável de 'ciência empírica' é tarefa que encerra dificuldades” (1975, p. 40, em SPOSITO, 2004, p. 32)

Para Sposito (2004):

a abordagem do empírico é fundamental para a Geografia, tanto para a produção da informação geográfica quanto para a da análise a partir da observação, acreditamos ser necessário insistir um pouco mais no método hipotético-dedutivo (p.32).

Segundo Sposito, o método que Popper denomina de empírico tende a chegar a produção de conhecimentos que devem ser passíveis de refutação, ou seja, de um teste de falseabilidade que, "uma vez superado, deixaria para a ciência a contribuição de algo que, cientificamente produzido, seria mais um acréscimo ao progresso da ciência" (2004, p.33).

1.2.2 O método fenomenológico-hermenêutico

Segundo Sposito, baseado em autores como Japiassu e Marcondes (1990) e Nunes (1989), a fenomenologia é uma corrente filosófica fundada por Edmund Husserl (1859-1938), com o intuito de um método de fundamentação da ciência e de constituição da filosofia como ciência rigorosa.

O postulado básico da fenomenologia é a noção de intencionalidade e considera que toda consciência é intencional na medida em que visa sempre algo fora de si, sempre tende para algo. Em outras palavras, o conhecimento é o resultado da interação entre o que o sujeito observa e o sentido que lhe fornece a coisa percebida. Assim, não se pode falar de uma observação independente dos significados que o sujeito atribui à realidade (SPOSITO, 2004).

Para Nunes (1989 apud SPOSITO, 2004): 
O projeto fenomenológico se define como uma "volta às coisas mesmas", isto é, aos fenômenos, aquilo que aparece à consciência, que se dá como seu objeto intencional. $\mathrm{O}$ conceito de intencionalidade ocupa um lugar central na fenomenologia, definindo a própria consciência como intencional, como voltada para o mundo (p. 35)

Segundo o autor é Husserl quem afirma: "toda consciência é consciência de alguma coisa". A perspectiva fenomenológica se baseava na pretensão dos seus defensores de “combater o empirismo e o psicologismo e superar a oposição tradicional entre realismo e idealismo" (SPOSITO, 2004, p.36).

Uma outra colocação é lembrada pelas palavras de Husserl, é o "problema do outro": "o outro não é só aquele que vejo, mas aquele que me vê e é também fonte transcendental de um mundo que lhe é dado" (SPOSITO, 2004, p. 37).

Uma outra autora lembrada por Sposito é Lencioni (1999, p.150-1) que afirma:

acima de tudo, é preciso ressaltar que a fenomenologia consiste num método e numa forma de pensar, nos quais a 'intencionalidade da consciência' é considerada chave porque a "consideração da percepção advinda das experiências vividas é, assim, considerada etapa metodológica importante e fundamental", procurando romper "a oposição entre sujeito e objeto, tanto quanto entre ator e observador" e firmando-se "uma visão antropocêntrica do mundo e uma recuperação do humanismo que a Nova Geografia havia feito desaparecer com seus modelos teóricos". Com essa perspectiva, espaço vivido, como "revelador das práticas sociais" passa a ser referencia central, colocando-se o lugar no centro da análise (SPOSITO,2004, p. 37).

Para Sposito é Armando Corrêa da Silva quem faz uma aproximação do método fenomenológico com a Geografia. Segundo esse autor, podem-se distinguir na fenomenologia dois traços fundamentais. O primeiro refere-se ao método que se debruça em descrever o fenômeno, aquilo que se dá de imediato. Renunciando ao empirismo e opondo-se ao idealismo, bem como renuncia ter como ponto inicial uma teoria do conhecimento. Dessa forma, o método em foco, destaca-se frontalmente contrário aos traços que predominam no século XIX. Por ultimo, o objeto da fenomenologia é constituído pela essência, ou seja, “o conteúdo inteligível ideal dos fenômenos, que é captado em uma visão imediata: a intuição 
essencial". Na discussão com a Geografia, Armando considera uma tendência aprender o significado do lugar, posto que esse conceito abrange não apenas o que se percebe, mas tudo aquilo que é construído pelo sujeito ao longo de sua experiência (SPOSITO, 2004, p. 38).

Sposito (2004) conclui:

No método fenomenológico, é o sujeito quem descreve o objeto e suas relações a partir do seu ponto de vista, depois dele se apropriar intelectualmente. $\mathrm{O}$ objeto torna-se elemento a jusante, correndo o risco de se tornar apenas o elemento a ser analisado.

E resume:

O método fenomenológico-hermenêutico contém a redução fenomenológica e a intencionalidade, indo além do subjetivismo através da consciência. Na pesquisa científica, a figura do pesquisador faz-se presente na redução do fenômeno para a sua abordagem total (2004, p.38-39).

Merleau-Ponty em Fenomenologia da percepção defende que "Tudo aquilo que sei do mundo, mesmo por ciência, eu sei a partir de uma visão minha ou de uma experiência do mundo sem o qual os símbolos da ciência não poderiam dizer nada (...)” (1999, p. 3). O mundo vivido deve ser compreendido como a fonte e a base de todo conhecimento e a legitimidade de toda consciência. O espaço geográfico, nessa concepção, "é considerado ao mesmo tempo como resultado concreto de um processo histórico (...) ou como uma construção simbólica que associa sentidos e ideias" (GOMES, 2003). A realidade local e a experiência vivenciada nos lugares turísticos na Amazônia são específicas e a compreensão dessa realidade possibilitará entender o lugar e como essa população percebe a atividade turística.

Para alguns geógrafos, como Herbe Xavier (2007), as pesquisas sobre o turismo, ligadas a interpretação fenomenológica da realidade - considerando o turismo como fenômeno social e espacial, portanto geográfico - esforçam-se por valorizar as experiências do homem em seu meio ambiente e nos lugares que visita, buscando, especialmente a ideia de pertencimento. 


\subsubsection{O método dialético}

Para Sposito (2004), o método dialético pode ser explicado como aquele que "procede pela refutação das opiniões do senso comum, levando-as à contradição, para chegar então à verdade, fruto da razão". O autor explica ainda, baseado em Lefebvre, que nessa perspectiva os que adotam o método confrontam as opiniões, os pontos de vista, os vários ângulos do problema, as oposições e contradições e, a partir de um ponto privilegiado, compreender a realidade de forma mais ampla possível.

Para Marx, a dialética de Hegel está de “cabeça para baixo". Utilizando-se do método dialético como sinônimo de método científico. Valorizando as variáveis econômicas do capitalismo, afirmando que a interpretação da realidade pela dialética científica depende da compreensão das categorias econômicas tidas como expressão teórica da realidade histórica de produção, ligadas a determinada fase do desenvolvimento da produção material. Para ele, a dialética requer o entendimento da noção de movimento na história (SPOSITO, 2004).

Ao explicarem as cinco leis da dialética Lefebvre e Chaptulin, enumeram a lei da interação universal ou da conexão: nada é isolado, cada fenômeno no conjunto de suas relações com os demais fenômenos, ou: as partes e a totalidade; A transformação da quantidade em qualidade e vice-versa; A unidade e interpenetração dos contrários: a ligação, a unidade, o movimento que engendra os contraditórios, que os opõe, que faz com que se choquem, que os quebra ou os supera; A negação da negação; e o desenvolvimento em espiral (da superação): a noção de movimento e do desenvolvimento da matéria, posto que toda formação material de um estágio mais elevado de desenvolvimento inclui, sob uma forma anulada (transformada), o que era próprio à formação de um estágio inferior de desenvolvimento, isto é, retém tudo o que era positivo, tudo o que foi obtido pela matéria em sua evolução anterior (SPOSITO, 2004).

Sposito (2004) explica, por fim, que:

No método dialético o sujeito se constrói e se transforma vis-à-vis no objeto e vice-versa. Nesse caso, teremos as antíteses e as teses em constante contradição e movimento. Geralmente, os trabalhos que se utilizam desse método se caracterizam por serem mais críticos da realidade por sua concretude e pelo fato de mostrarem as contradições existentes no objeto pesquisado (p.46). 
1.2.4 Método miltoniano do espaço

Um diálogo com as obras de Milton Santos parece ser imprescindível para adentrar na discussão do método geográfico por ele concebido. Suas obras e suas formulações acompanham a evolução do seu pensamento, centrado no desenvolvimento da sociedade de seu tempo, caminha com ele, vê o mundo e o interpreta, dessa forma ao longo de sua existência formula ideias e conceitos que dão uma continuidade à definição de um método. Nesse sentido, optou-se por acompanhar o raciocínio de Lustosa (2011) sobre esse autor e seu método de pesquisa.

Assim, o espaço tem uma vocação "solidária" sofrendo ações dos atores hegemônicos forçando a desorganização. Os atores hegemônicos estão nos espaços fluxos. Já os espaços com vocação solidária, aquele espaço que ainda não sofreu ação das grandes corporações, ele chama de espaço banal. O espaço banal é residual, pois as ações pragmáticas que são feitas dentro do espaço são avassaladoras. Desse modo, Santos aborda que os donos do tempo, são também os donos do espaço. Abordando todos esses conceitos, pode-se dizer que a sociedade seria o ser, e o espaço seria a existência.

Santos é um dos primeiros geógrafos a recorrer à filosofia na discussão de um método, neste sentido, afirma-se que a contribuição do seu pensamento está além da própria Geografia.

A respeito do seu posicionamento quanto ao método, esta discussão se baseará nas suas ideias expostas no livro Espaço e Método (SANTOS, 1997), que foi publicado pela primeira vez em 1985, além de outras três obras: Espaço e Sociedade (SANTOS, 1979), A Natureza do Espaço (SANTOS, 2004), publicado em 1996, e Por Uma Outra Globalização (SANTOS, 2004b), este publicado no ano de 2000, escolhidas com o objetivo de acompanhar as possíveis mudanças no pensamento do autor e da filosofia que embasa as suas concepções geográficas.

Ao discutir o método em Geografia, Santos (1997) expos sua concepção de método diferentemente daquilo que vimos discutindo até agora. Uma tentativa de sintetizar seu 
entendimento de espaço, ele afirma que as categorias do método geográfico são estrutura, processo, função e forma.

O método seria decomposto da seguinte maneira:

Forma é o aspecto visível de uma coisa. Refere-se, ademais, ao arranjo ordenado de objetos, a um padrão. Tomada isoladamente, temos uma mera descrição de fenômenos ou de um de seus aspectos num dado instante do tempo. Função (...) sugere uma tarefa ou atividade esperada de uma forma, pessoa, instituição ou coisa. Estrutura implica a inter-relação de todas as partes de um todo; o modo de organização ou construção. Processo pode ser definido como uma ação contínua, desenvolvendo-se em direção a um resultado qualquer, implicando conceitos de tempo (continuidade) e mudança (SANTOS, 1997, p. 50).

A esse processo, que contém formas de diferentes épocas, cada qual com sua função, Santos (1997) chama de uma estrutura. O espaço é uma Totalidade, uma Universalidade (LUSTOSA, 2011)

Em outro livro, Santos (1979) sugere que se deve levar em consideração a Formação Econômica e Social (FES) do Estado-Nação. Coerente com seu tempo, pois na década de 1970, tanto os países ditos de Primeiro Mundo quanto os de Terceiro exerciam um controle rígido sobre a economia e sobre a sociedade. Uma forte intervenção estatal sobre economia, exemplificado pelo "Estado do Bem-estar Social" e o modelo Keynesiano, como ocorreu nos Estados Unidos, na França, no Japão etc., influenciando decididamente na produção do espaço geográfico nesses países.

No outro extremo, a União Soviética, também estava totalmente fechada, controlando a economia, inclusive com a planificação econômica. E nos países do "Terceiro Mundo" eram dominados por Estados fortes, com é o caso das ditaduras na Bolívia, Chile, Argentina e no Brasil. Portanto, segundo Lustosa (2011), parece acertado para essa época, levar em consideração a F.E.S do Estado-Nação nas pesquisas em Geografia.

Já nos anos 1980, não se fazia tão marcante nos países dito do Terceiro Mundo, pelo menos na aparência, essa "ideologia nacionalista". As quedas das ditaduras militares na América Latina davam provas que o socialismo não era tão ameaçador assim, como 
ideologicamente se fazia pensar nas décadas passadas. Por outro lado, com a queda do Muro de Berlin e a desintegração da União Soviética, começa a se configurar um novo marco geopolítico, dando origem a tão esperada "nova ordem" econômica, sonhada pelos adeptos do liberalismo ou neoliberalismo econômico. Apesar de já se falar nisso desde o período quinhentista das Grandes Navegações, a mundialização ou globalização, ganham espaço de reflexão totalizante, o que, aliás, Santos (2004) vai chamar de "apenas mais um período da história".

Segundo Lustoza (2011), esse período faria Santos, praticamente, abandonar as categorias de análise - forma, função, processo, estrutura, F.E.S do Estado-Nação - utilizadas nos estudos até a década de 1980. Coerente com seu tempo, visto que nessa época, pelo menos aparentemente, já não existia mais intervenção estatal nos rumos da economia. Uma observação genérica aponta para uma incoerência ao se falar em "intervenção" do Estado na economia, quando, pelo contrário, o que se observava era um total abandono do compromisso estatal quanto às questões sociais, principalmente nos países subdesenvolvidos.

Por isso, na sua obra de 2000, Santos (2004b) faz uma análise desse novo espaço "fragmentado", o que ele, chama de um espaço nacional das empresas internacionais. Nesse sentido é que Santos vai se debruçar em interpretar as redes formadas pelas empresas globais, inclusive na comunicação de massa. Santos (2004) classifica esse novo período da história como "período técnico-científico-informacional", onde a ciência e principalmente a informação passam a ser decisivas, visto que as empresas globais têm um conhecimento instantâneo dos territórios por elas apropriados. O desenvolvimento da microeletrônica e da informática, entre outras, permite a essas empresas ter um controle dos recursos econômicos distribuídos pela Terra. Para ele, o desafio do geógrafo, nesse contexto, é procurar entender esse espaço, um verdadeiro híbrido.

Todavia, é no fim de sua vida (falecido em 2001) que Milton Santos, revela a verdadeira face dessa nova ordem mundial, não apenas o seu lado sombrio, mas, ao mesmo tempo, o da possibilidade. Nesse livro - Por Uma Outra Globalização: do pensamento único à consciência universal $(2000,2004 b)$ - Santos analisa a globalização da forma como ela aparece (como fábula), como ela realmente é (perversa), e como ela pode ser: uma outra globalização (mais humana). 
Essa globalização como fábula, um mito, se apresenta nos arautos do pensamento único, do livre comércio mundial, anunciavam o surgimento de um período em que as desigualdades regionais seriam, paulatinamente, a ser eliminadas. Com a globalização, falavase em integração mundial, em aldeia global, pois o desenvolvimento da informação geraria um pensamento único, uma única forma de pensar, uma única cultura em nível mundial. Para tal integração cultural, sugeria-se a extinção das fronteiras, a morte do Estado-Nação, portanto, uma integração também na esfera política.

Desmistificando essa globalização, Santos a caracteriza como perversa, pois não são todas as pessoas, mas pelo contrário, apenas umas poucas empresas e poucos Estados que se beneficiam da informação. Segundo Lustosa (2011), a ideia de uma aldeia global é uma fábula, afinal poucas pessoas têm computadores e a mídia televisionada, até mesmo a escrita é outra forma de manipular a informação. A informação, nesse sentido, que chega à população em geral já é filtrada pelos veículos de comunicação, não é sequer informação dos fatos, somente os que interessam àqueles que controlam a mídia. Eis o que Santos (2004) chama de violência da informação.

Santos (2004) acrescenta, ainda, que a extinção dos Estados é outra fábula, pois poucas empresas se beneficiam da "neutralidade" ou da fraqueza do Estado. Além da violência da informação, há a violência do dinheiro, quando se verifica que aquilo que poderia ser uma poupança nacional, por exemplo, passa a ser uma poupança para as empresas internacionais, instaladas nos países "em desenvolvimento". Essa poupança é utilizada para pagamento de royalties e remessas de lucros, num sentido único em direção aos países desenvolvidos. Para Santos, o objeto de estudo do geógrafo é algo que está em movimento, porque o homem é visto como sujeito, ele é ativo e transforma o espaço. Até aqui a intervenção humana tem sido, quase sempre, perversa para a maioria da humanidade, mas poderá ser de outra maneira, mais humana.

Em vista do método miltoniano, Cruz (2003) aponta a perspectiva de compreender o fenômeno turístico a partir do entendimento da produção do espaço para o turismo. Para ela uma análise consistente sobre a participação dessa atividade na produção do espaço geográfico, ou como ela denomina territórios turísticos, deve levar em conta o conjunto de relações em que a atividade turística se desenvolve, assim como a dimensão global e local, tendo como premissa que o turismo, como atividade social e espacial, é apenas uma parte desse complexo jogo de relações. 
Para a continuidade das discussões neste trabalho, baseamo-nos nos fundamentos do pensamento de Santos, para quem só é possível entendera realidade local se percebemos a dimensão espacial da mesma, além do que nossos olhos podem abarcar. Nesse sentido, teremos que fazer a crítica dialética do fenômeno turístico, pois este se insere numa dinâmica que envolve relações sociais contraditórias entre si, numa sociedade também contraditória.

Além desse entendimento, faremos uso de técnicas de abordagem com entrevistas e aplicação de questionários que nos possibilitaram uma maior aproximação com a realidade local, principalmente quando discutirmos a importância do turismo para a população de Parintins. Nesse caso estaremos nos aproximando da análise fenomenológica, visto que o percebido pode dar algumas respostas sobre a realidade vivida por essa parcela da população.

O uso de um método mais específico e suas técnicas, como da Cartografia, é indispensável para pensar o espaço de estudo. O objetivo é fazer um levantamento cartográfico das características físicas (naturais) e sociais do município e a partir dessa sistematização e das experiências pessoais em campo, construir um mapa de síntese ambiental e turística do município em estudo. Essa experiência nos indicará o potencial turístico dos diversos lugares e pode servir como referência de políticas públicas voltadas ao turismo ou ao ecoturismo.

Um estudo de caso, apesar de permear todos essa pesquisa, será mais caracterizada no estudo da região da Valéria e Paraná de Parintins, definidos no mapeamento cartográfico deste trabalho. Isso será feito para detalhar as características do turismo ou da exploração turística nesse espaço definido, com uma aproximação da realidade local e do fenômeno turística representado pelas paradas de transatlânticos neste local. Será importante, também, para perceber as potencialidades locais e superar esse tipo de visitação para um turismo de base comunitária. 


\section{CAPITULO II}

\section{A CONSTRUÇÃo da AMAZÔniA: A FORMAÇÃo DE UMA REGião EM VIAGENS E TURISMO}

Falar de turismo na Amazônia e no Amazonas requer que se conheça um pouco de sua história e das formas como os espaços foram se organizando. A Amazônia é resultado de uma construção psicológica, mitológica, muito antes de ser uma descoberta dos colonizadores europeus do século XVI. É importante reconhecer que desde seus primórdios, como espaço colonial e com sua gente e riquezas naturais subjugadas, a Amazônia foi produzida pelos de fora da região. Seres que, vendo-a de fora para dentro, sempre tiveram uma visão distorcida e estereotipada dela, impondo um ritmo diferente de organização do espaço, sem considerar suas peculiaridades ecológicas e menos ainda as antropológicas. Eis porque cabe perguntar até que ponto isso interfere na produção do espaço na região até o momento atual, considerando as políticas públicas aqui implementadas, ou, até onde isso implica a produção de espaços turísticos na região?

\subsection{A ocupação e primeiras viagens pelo rio Amazonas}

Para começar a falar do turismo na Amazônia é importante retomar o momento das expedições colonizadoras e desbravadoras da região, no Período Colonial, mais precisamente entre os meados do século XVI e do século XVII. Não que se tratasse de expedições que propiciassem o lazer, como nos dias de hoje, mas a prática de desbravar uma região desconhecida trazia consigo o deslumbramento, uma das características do turismo moderno que se traduz na busca do diferente, do exótico. Claro que a preocupação dos colonizadores era com a tomada e posse das novas terras para a Coroa lusitana ou espanhola, bem como a descoberta de riquezas que realmente justificassem o alto investimento da expedição. 
Os mapas do século XV e posteriores retratavam bem essa preocupação com as riquezas das regiões recém-descobertas, apresentando de forma pictográfica os recursos naturais e humanos (escravos) que poderiam ser explorados pelas metrópoles coloniais do período (figura 3).

O mapa retratando a Colônia portuguesa em 1556 possibilita perceber o que foi colocado anteriormente, pois denota a preocupação pela parte leste (litoral), em detrimento do interior, tendo a parte norte (Amazônia), como uma região pouco conhecida, "não descoberta" (no mapa o litoral atlântico está para o sul).

Figura 3 - Mapa datado de 1556, creditado a Giovanni Battista Ramusio.

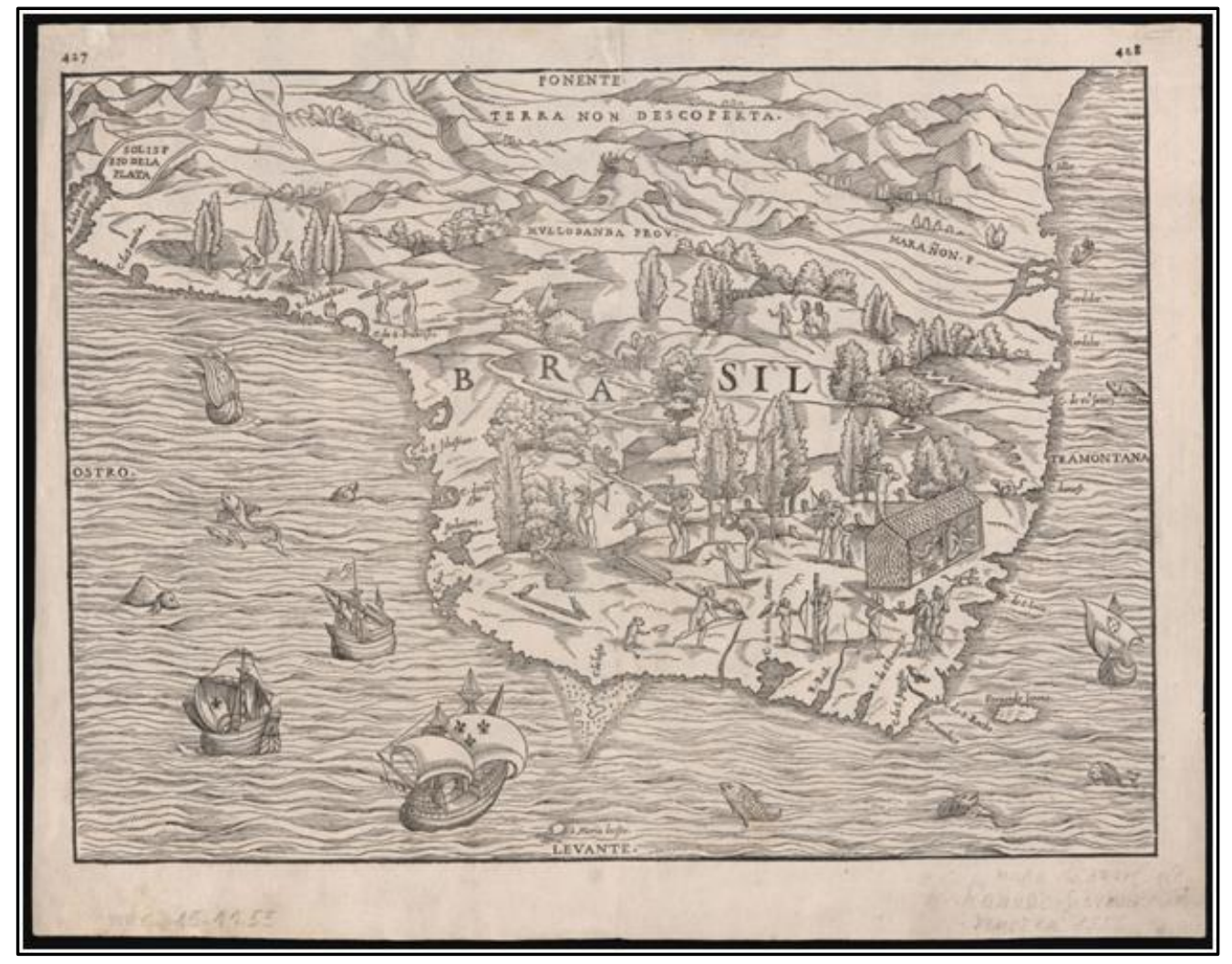

São as expedições científicas, no século XIX, que nos trazem uma nova luz sobre esse processo de desbravar e buscar o conhecimento sobre estas terras, ao que modernamente dá-se o nome de turismo. Porro (1995) afirma que essa parte das terras lusitanas foi se tornando conhecida lentamente pela cultura europeia e para o império brasileiro, por se tratar 
de um imenso território, "demandou mais de quatro séculos, e na verdade ainda não terminou" (p. 9).

As narrativas sobre as terras "descobertas" nas Américas têm início com a chegada de Colombo em 1492, fato que suscitou uma imensa curiosidade nos europeus pelas novas terras, principalmente, na busca de riquezas e posses (GALEANO, 1989).

No Brasil, com a chegada de Cabral e o envio das cartas de Pero Vaz de Caminha, em 1500, os mitos e fábulas envolvendo essas terras se estenderam e a idealização de um país “onde corre o leite e mel" e o "El Dorado" são bem conhecidas. Todavia, a penetração do colonizador português pelo rio das Amazonas não aconteceu de imediato. Segundo Valentin (2005), nos anos que se seguiram ao descobrimento, foram os espanhóis que excursionaram pela região, inclusive é atribuída à Espanha a descoberta e a denominação do grande rio. Esses fizeram vinte e duas expedições pela Amazônia, enquanto os franceses nela estiveram por sete vezes e os holandeses realizaram cinco viagens à região.

Foi somente a partir do século XVII que começou a haver por parte dos portugueses uma preocupação maior com a ocupação e domínio dessas terras. Ainda assim, a primeira expedição foi organizada e implementada apenas em 1637, tendo como comandante Pedro Teixeira, que foi o primeiro a fazer a viagem da foz do Amazonas até Quito, ida e volta tendo como ponto de partida e chegada a hoje cidade de Belém, estando a importância dessa expedição em ter feito a maior e melhor descrição do território, estabelecendo marcos divisórios com as colônias espanholas. A expedição foi descrita nos relatos de viagem dos padres Cristobal de Acuña e Alonso de Rojas (VALENTIN, 2005, p. 51)

As "imagens" criadas sobre a Amazônia e sua "invenção" enquanto imaginário do pensamento europeu, já foram tratadas por outros autores como Marilene Corrêa da Silva (1989); Neide Gondim (2007); Carlos Walter Porto Gonçalves (2008), entre outros.

Silva (1989) desvela a constituição do espaço amazônico pelas diversas formas que se sucederam histórica e geograficamente. Primeiro uma "Amazônia Indígena”, bem anterior à chegada dos colonizadores, formada por povos nativos, indígenas, com diferentes níveis de desenvolvimentos de suas técnicas, desde coletores e caçadores a agricultores, artesãos, pescadores, etc, plenamente adaptados ao meio em que viviam. 
Em seguida, a "Amazônia Colonial" forjada no processo de dominação territorial e comercial e, finalmente, a "Amazônia brasileira" que se caracteriza pela constituição de um Estado Brasileiro, imperial e ligado aos interesses comerciais europeus.

Importante resguardar nesse processo uma "Amazônia Revolucionária”, com a luta dos Cabanos, para, assim, definir um "Paiz do Amazonas", não sem antes destacar e esclarecer os diversos aspectos passíveis de abordagem no sentido de revelar o "mistério" amazônico que estava por trás de sua fundação. "À magia contida no mito, na invenção literária, no registro dos viajantes, sobrepõe-se a necessidade da pesquisa, da investigação sistemática, do esforço interpretativo, o que não exclui as representações acima aludidas" (SILVA, 1989, p. 11).

Gondim (2007) em seu livro A invenção da Amazônia, assinala que foi criado um mito sobre as novas terras. A autora retoma os escritos literários e crônicas dos navegantes desde o século XII até o "século das luzes", quando começam a chegar à Europa os primeiros relatos sobre a Amazônia, para perceber que "a Amazônia não foi descoberta, sequer foi construída. Na realidade, a invenção da Amazônia se dá a partir da construção da Índia, fabricada pela historiografia greco-romana, pelo relato dos peregrinos, missionários, viajantes e comerciantes" (p. 13). Uma Amazônia mitificada muito antes de sua descoberta.

Gonçalves (2008), por sua vez, vai falar sobre as imagens criadas acerca da Amazônia, para defender que "a imagem que normalmente se tem a respeito da região amazônica é mais uma imagem sobre a região do que da região" (p.12). Nesse sentido, a região sempre é vislumbrada pela interpretação que tem o colonizador, o dominador, inclusive o estado, sobre esse espaço e sua população desde tempos coloniais. Para ser, então, taxativo:

Assim a Amazônia nunca é é sempre o vir-a-ser. E esse vir-a-ser nunca é o vir-a-ser das suas populações que, na região, constroem no seu dia-a-dia suas vidas, suas histórias, seus espaços, suas culturas. Ao contrário, é o vir-a-ser daqueles que veem a região pelo seu potencial de exploração futura. É, na verdade, uma reserva de recursos (p.25).

O estudo da motivação para viajar, necessariamente ligada ao turismo em nossos dias, bem como a criação de um ideário psicológico, o desejo inconteste pela aventura e 
ambição (fato presente no pensamento medieval, do período do contato) e a mitificação de um lugar ainda desconhecido tem sido objeto de pesquisadores como Luchiari (2000), Carlos (2002), Gastal (2005).

Na atualidade, segundo Luchiari (2000), a mitificação dos lugares turísticos está ligada à força que tem a mídia de vender paisagens e torná-las desejo de consumo de todo potencial turista. Essa forma de mitificação torna a natureza e seus recursos propriedade privada, possibilitando e criando com isso a privatização de lugares até então considerados públicos. Mas a autora enfatiza que "o fenômeno turístico não é um mito, mas sim mitifica a realidade, dando-lhe novos conteúdos" (p. 36).

Carlos (2002) argumenta que a indústria do turismo é capaz de transformar os espaços em espaço para o turismo, tornando o presente e o passado do lugar em objeto de desfrute para os turistas.

A indústria do turismo transforma tudo o que toca em artificial, cria um mundo fictício e mistificado de lazer, ilusório, onde o espaço se transforma em cenário para o "espetáculo" para uma multidão amorfa mediante a criação de série de atividades que conduzem a passividade, produzindo apenas a ilusão da evasão, e, desse modo, o real é metamorfoseado, transfigurado, para seduzir e fascinar (CARLOS, 2002, p. 26).

Gastal (2005), ao explicar o porquê dos imaginários esclarece que viagem e imaginários sempre andaram juntos. Para a autora, "enfrentar o desconhecido, ou simplesmente adentrar ao novo, causa uma certa instabilidade na pessoa" (p.57).

Não é difícil imaginar como os europeus olhavam com espanto a possibilidade do novo, o medo a dificultar e ao mesmo tempo estimular a busca do desconhecido, pois, ao mesmo tempo, significava alcançar as belezas e as riquezas imaginadas desses lugares.

Porro (1995) também confirma isso quando acrescenta a forte influência dos mitos no processo de colonização da Amazônia, relatando a descrição feita por frei Gaspar de Carvajal, o cronista da expedição de Francisco Orellana, em 1542, quando de sua passagem 
pela foz do rio Nhamundá, estando os viajantes "preparados e condicionados" para verem "coisas maravilhosas":

E foi Deus servido que, ao dobrar uma ponta que o rio fazia, víssemos adiante branqueando na costa muitos e mui grandes povoados. Aqui demos de chofre na boa terra e senhorio das amazonas (CARVAJAL apud PORRO, 1995, p. 42).

Porro acrescenta que ao interrogar um indígena sobre os líderes do lugar e a presença das mulheres guerreiras, as perguntas induziam às respostas desejadas e o indígena respondia o que os estrangeiros queriam ouvir, até porque havia uma grande diferença cultural entre os interlocutores (PORRO, 1995).

É Porro que observa, no citado caso do contato com as amazonas narrado por Carvajal, haver erros de descrição explícitos, denotando o esforço para criar uma espetacularização do acontecido. A descrição do lugar pelo índio interrogado indica localização andina, "deve ter sido feito aos espanhóis nos Andes peruanos”, mas os mesmos julgaram ser adequado colocar naquele relato (1995, p. 43).

Não sem intenção, principalmente num momento em que era difícil conseguir homens para armar as embarcações para as expedições.

Porro conclui:

O mito das amazonas americanas inscreve-se no grande ciclo daquela 'visão do paraíso'(...). Junto com o Eldorado, do País de Rupa Rupa, da Gran Omagua e do lago Paititi, foi a força motriz que impeliu aventureiros espanhóis a descerem os Andes e explorarem a Amazônia" (1995, p. 43, grifo nosso).

De qualquer forma, os viajantes, cronistas e cientistas que passaram pela Amazônia, fizeram "turismo". Todos estavam imbuídos pela busca do novo, da descoberta, do 
conhecimento de uma nova realidade, de uma cultura. E como ainda hoje acontece, muitas das suas informações mobilizam e atraem novos turistas.

\subsection{Viagens e viajantes por Parintins}

Considerando as viagens científicas empreendidas a partir do século XIX pela região destacadas por Saunier (2003), especialmente quando de suas passagens por Parintins, percebe-se a contemplação feita pelos viajantes por meio da descrição feita por estes do espaço visitado.

Von Martius viajou pelo Brasil entre 1817 e 1832. Quando navegava o rio Amazonas passou por Parintins em 1820: “(...) algumas palhoças ao sopé de uma colina de uns 200 metros de altura, coberta de mata virgem densa (...)". Estava se referindo à atual região da Valéria e depois continua:

Em seis horas de viagem, alcançamos Vila Nova da Rainha, ou Tupinambaranas [Parintins], que se acha situada sobre a margem meridional, 20 pés acima do nível das águas (...). O lugarejo compõe-se de diversas filas de cabanas baixas, quase todas sem janelas, cobertas com folhas de palmeiras (...). A estadia em Tupinabaranas proporcionou-nos muitos espetáculos da vida dos índios" (VON MARTIUS por SAUNIER, 2003, p. 44).

Von Martius e Spix fazem, ainda, uma das melhores descrições da vila em referência:

A situação da vila é extremamente aprazível. Da alta margem, avista-se uma grande parte do Amazonas, que, até a primeira ilha, tem uma légua de largura, e daí se estende, em diversos canais, até a vila de Faro, cuja distância se calcula em sete léguas. $\mathrm{O}$ ar é puro, o horizonte, relativamente vasto para estas regiões, é claro e sereno; o calor é quase diariamente atenuado por fresca viração, que sopra rio acima, e a praga de mosquitos não flagela demais. Os arredores mais próximos são de matas aqui e acolá 
arejados por derribadas e roças, que passam para arbustos cerrados ou capinzais, onde pasta algum gado. Mais para dentro, dizem que se estendem vastas campinas sobretudo em torno das lagoas piscosas, muito procuradas pela gente do lugar nos meses secos (SPIX \& MARTIUS, 1981).

Alfred Russel Wallace, em seu relato Viagens pelos rios Amazonas e Negro, de 1948, juntamente com H. W. Bates, destaca:

(...) quatro dias depois chegamos a Vila Nova sãos e salvos. Era um longo caminho o que já havíamos percorrido, e isso me deixou deveras satisfeito. Na praia, fomos cordialmente recebidos pelo vigário local (...). Não houve como recusar a hospitalidade.(...) Acredito que Vila Nova, entre julho e outubro, seja uma localidade excepcional para pesquisa entomológicas (WALLACE por SAUNIER, 2003, p. 45-46).

O casal Agassiz, Louis e Elizabeth, visitou o Brasil entre 1865 e 1866, passando por Parintins em agosto de 1865. Ela descreve, com seu olhar eurocêntrico, as atividades das mulheres:

Nunca se vê um índio trabalhar nos cuidados internos da casa; não carrega água nem lenha, nem pega mesmo nas coisas mais pesadas. Ora, como a pesca só se dá em determinada estação, ele folga a maior parte do tempo. As mulheres, ao contrário, são muito laboriosas... Esperança está constantemente ocupada, quer em casa, quer fora. Ela rala a mandioca; seca a farinha, comprime o tabaco, cozinha, varre os quartos (AGASSIZ; AGASSIZ por SAUNIER, 2003, p. 52).

Já o médico alemão Robert Avé-Lallemant, que clinicou no Brasil de 1838 a 1855 e que depois, em 1857, fez uma excursão pelo Amazonas para avaliar a situação dos imigrantes alemães na região, reconhece a visão distorcida da Amazônia chegada à Europa, à época da conquista, afirmando: 
(...) toda a Europa se mantinha tensa, recebia pasmada toda notícia de continentes recém-descobertos e enfeitava com fábulas e quimeras tudo o que não era positivo, houve época, em que se estava convencido do aparecimento, nalguns afluentes do grande rio sul-americano, de mulheres gigantescas, e da existência de homens de cauda (AVÉ-LALLEMANT, 1980, p. 59)

E sobre a descrição da região, à altura de Parintins, acentua:

Não tardou avistarmos (...), na margem direita do rio, Vila Bela da Imperatriz (...). Vila Bela da Imperatriz fica a 20 pés de altura acima do nível mais elevado do rio, sobre um campo verde, que encosta na floresta por trás da cidade (p. 89).

Vê-se, portanto, não ser de hoje que a cidade de Parintins é contemplada pela sua beleza natural, sua possibilidade de abrigo, descanso, alimentação, por estar cercada pela disponibilidade farta de recursos naturais ao seu redor. Daí pensar que também em nossos dias essa riqueza natural possa possibilitar o desenvolvimento do turismo na região.

\subsection{Parintins: história e ocupação}

A história do (re)conhecimento do espaço amazônico data da época da colonização do continente americano pelos europeus, basicamente a partir das primeiras décadas do século XVI. A expedição de Francisco Orellana, descrita pelo Frei Gaspar de Carvajal, desde Quito, no Peru, descendo o rio Napo e Amazonas até o Atlântico, teve a duração de oito meses entre 1541 e 1542 e foi a primeira a descrever o grande rio e a região banhada pelo mesmo. Segundo Porro (1995), não há nenhuma citação às ilhas Tupinambarana e seus habitantes, ou outros nomes pela qual foi conhecida, nos relatos de meados do século XVI que digam respeito à tribo cujo nome será o mesmo pelo qual o arquipélago passou a ser conhecido ou que poderiam estar se estabelecendo na região. Isto porque, também segundo o autor, há 
relato de Diogo Nunes Machiparo ter encontrado um representante da etnia $600 \mathrm{~km}$ rio acima (BRAGA, 2002, p. 270).

Conforme Braga, a ilha de Tupinambarana foi descrita nos relatos do padre Cristóbal de Acuña, da Companhia de Jesus, integrante da expedição de Pedro Teixeira pelo rio Amazonas, do Pará a Quito, em 1637 (BRAGA, 2002, p. 270).

Acuña, em seu relato, faz uma descrição mais detalhada do lugar com suas diversas ilhas e uma maior que os índios Tupinambá, fugitivos das perseguições engendradas pelos portugueses no litoral de Pernambuco, vieram ocupar. Não só essas, mas

sempre pelo lado esquerdo, atingiram as faldas da cordilheira que, desde o estreito de Magalhães, circunda toda a América; e desbravando os rios que dali descem rumo ao oceano, alguns chegaram a encontrar-se com espanhóis do Peru que habitavam as cabeceiras do rio Madeira (...). Diz-se também que, como saíram tantos, não podendo sustentar-se todos juntos naqueles ermos, foram-se espalhando por tão longo caminho, que deve ter no mínimo mais de 900 léguas e uns ficaram vivendo em algumas terras e outros em outras, pelo que, sem dúvida, toda aquela cordilheira estará cheia deles (ACUÑA, 1994, p. 74 - 148, citado por BRAGA, 2002, p. 271).

Ainda sobre a presença dos Tupinambarana na região, Porro (1995, p. 53) acredita que os mesmos

teriam atravessado as chapadas da Amazônia meridional até chegarem, pelo menos alguns deles, aos primeiros estabelecimentos espanhóis na Bolívia. Daí terem descido o Madeira para se fixarem finalmente na ilha que levaria seu nome.

Segundo Braga (2002), o nome Tupinambarana significa, em língua Tupi, “Tupinambá não verdadeiro”, fato devido à “degeneração, em que então já se reconheciam, como não mais os antigos e intrépidos dominadores de todo o Brasil, como não mais de sustentarem o seu antigo brio e independência" (AMAZONAS, 1984, Apud BRAGA, 2002, 
p. 273). Nesse sentido, usar-se-á a denominação de Tupinambá quando se estiver falando da etnia fora da Amazônia e Tupinambarana para aqueles grupos que se encontram na região.

Provavelmente, a migração dos Tupinambá deve ter se iniciado no segundo quartel do século XVI e seguido até o começo do século XVII, quando não poucas "mas uma série de movimentos messiânicos tenham levado muitos grupos Tupi do nordeste, em ondas sucessivas através da Amazônia" (PORRO, 1995). Já os relatos de Acuña estabelecem a ocorrência dessa migração no ano de 1600, em apenas três tropas (citado por BRAGA, 2002, p.273).

Os primeiros relatos descrevendo o contado com os índios das Tupinambaranas datam de 1657 e foram feitos pelos jesuítas Manuel Pires e Francisco Veloso, vindos do Maranhão, em viagem pelo rio Negro. No ano seguinte foi a vez do provincial dos jesuítas, o padre Francisco Gonçalves, que estava acompanhado de Manuel Pires e veio fixar-se na região em 1660, para prestar assistência espiritual aos índios (CÉRQUA, 1980; BRAGA, 2002).

Baseado em Cérqua (1980) e Saunier (2003) é possível estabelecer uma periodização de Parintins, dos primeiros relatos, sua fundação até os dias atuais:

1. Em 1542, na expedição de Orellana, Carvajal relata a passagem por um povoado onde foram vistas cabeças de índios secas e espetadas, e ao qual os expedicionários deram o nome de Las Picotas (pelourinho). Logo depois avistaram a Sierra Gran (serra de Parintins).

2. Em 1658, é feita a primeira visita pelo padre Francisco Gonçalves, provincial da colônia, que ficando na ilha denominou-a Aldeia dos Tupinambaranas.

3. Em 1669, é fundada a primeira missão na ilha, denominada pelo Padre Betendorf de Missão de São Miguel dos Tupinambaranas. Era 27 de setembro.

4. Em 1723, Padre Manoel dos Reis assume a aldeia e a denomina Missão de São Francisco de Xavier dos Tupinambaranas.

5. Em 1749, o padre José Gonçalves da Fonseca, por ocasião de sua passagem pelo lugar, vindo do Pará a caminho de Mato Grosso, denomina-a de Maracá. Pelos relatos do padre José Gonçalves, durante os anos de 1743 até 1749 houve 
uma redução significativa de moradores devido às epidemias de sarampo, varíola e beribéri.

6. No período pombalino, que se estendeu até 1796, os jesuítas foram expulsos da Amazônia e a missão de São Francisco Xavier dos Tupinambaranas entra em decadência.

7. Em 1796, chega ao lugar José Pedro Cordovil, capitão de milícias, com escravos e agregados, que a denomina Fazenda Cordovil. Tornou-se grande explorador dos índios.

8. Em 1803, passa oficialmente à categoria de missão e recebe o nome de Vila Nova da Rainha por Dom Marcos de Noronha, o Conde dos Arcos, CapitãoMor do Pará.

9. Em 1804, um posto de fiscalização de produtos transportados pelo rio em direção ao Grão-Pará é instalado em Vila Nova, comandada pelo Capitão de milícias Antonio Vieira Corrêa da Maia. Dois anos depois o posto é transferido para as faldas da serra de Parintins, funcionando até 1824.

10. Em 1832, passaria a se chamar, com a troca do padroeiro, de Freguesia de Nossa Senhora do Carmo de Tupinambarana.

11. Em 14 de março de 1848, ganhou um novo nome com a elevação de categoria para Villa Bela da Imperatriz.

12. Em 15 de outubro 1852, a Lei do Amazonas de $\mathrm{N}^{\circ} 2$, ganhou a categoria de Vila e Município, com o nome de Vila Bela da Imperatriz. Em 14 de março de 1853 foram instalados a Vila, sede do município e o território do Município.

13. Em 24 de setembro de 1858, foi elevada à categoria de Comarca, desta vez com o nome de Parintins, por meio de uma emenda apresentada pelo Deputado Padre Torquato Antonio de Souza.

14. Em 30 de outubro de 1880 , definitivamente, foi elevada à categoria de Cidade com o nome de Parintins, pela Lei $\mathrm{N}^{\circ} 499$, de iniciativa do deputado Emilio José Moreira, da Assembleia Legislativa Provincial, projeto sancionado pelo presidente da Assembleia, o Dr. Sátiro de Oliveira Dias.

Até então, Parintins compreendia o que hoje são os municípios de Barreirinha e Nhamundá. Mas, em 1881 foi desmembrado do município o território que constituiu o município de Vila Nova de Barreirinha e em 1955, com a criação do município de Nhamundá, 
pela Lei Estadual n 96, de 19 de dezembro de 1955, Parintins teve seu território ainda mais reduzido (IBGE, 2012).

A extensão territorial do município era de quase $26.000 \mathrm{~km}^{2}$, compreendendo terras que faziam fronteira com o Pará até as Guianas, ao norte. Havia uma área de litígio com o Pará incluída nessa extensão.

A perda de território se deu, inicialmente, em 1881, com o desmembramento de Barreirinha (5.751 km², segundo o IBGE, 2012). Depois, em 1955, com a criação do município de Nhamundá, ficou com menos $14.040 \mathrm{~km}^{2}$ (14.106 km², segundo IBGE, 2012). Posteriormente, do litígio com o estado do Pará perdeu mais $4.238 \mathrm{~km}^{2}$, ficando com os atuais $7.069 \mathrm{~km}^{2}$, segundo Saunier (2003). No entanto, oficialmente, Parintins conta hoje com um território de $5.952 \mathrm{~km}^{2}$, segundo o IBGE (2012).

2.3.1 Parintins de vila à "capital da cultura e do folclore amazonense"

Até os anos 1950, Parintins configurava-se como uma pequena e pacata cidade, que não apresentava grande crescimento horizontal. Ao sul estava a pista de pouso, a leste a lagoa da Francesa e oeste a igreja de São Benedito. Um pouco maior do que o núcleo de sua fundação (sobre a expansão da cidade ver o mapa 3).

Segundo o estudo feito pela Câmara Municipal de Parintins, nos anos 1960, quando compreendia a $4^{\text {a }}$ legislatura da casa:

$\mathrm{O}$ perímetro urbano expandia-se principalmente à Oeste (constituindo hoje os bairros de São Benedito e São José), com maioria das casas de madeira cobertas de palha. À Leste Parintins estendia-se até o final do Campo de Pouso (hoje o final da Av. Nações Unidas) até onde hoje é o Hospital Jofre Cohen. Ao Norte, a margem direita do Rio Amazonas, com parte da frente protegida com o muro de arrimo, cais do porto e algumas escadas de alvenaria. Ao Sul compreendia o Campo de Pouso (hoje Câmara Municipal, Bumbódromo e instalações do SAAE ao lado da Rua Paraíba). A cidade passou a ter ligação direta com as comunidades do Aninga, Parananema e Macurany através da abertura e melhoramento de estradas (BUTEL et al, 2011, p. 9-10). 
Segundo os relatórios da Câmara Municipal, a causa para um "crescimento desordenado" da cidade desse período era devido à ausência de Plano Diretor. Os vereadores já observavam as dificuldades da administração da cidade quanto à eficiência dos serviços públicos e a imigração de populações da zona rural e dos municípios vizinhos (p. 178).

As décadas de 1960 e 1970 são caracterizadas pela introdução da produção e beneficiamento da juta na região amazônica. A juta foi adaptada na região pelos japoneses que se instalaram na Vila Amazônia, no município de Parintins. Logo chegaram indústrias de beneficiamento da fibra. Tanto no campo como na cidade houve um significativo crescimento econômico (BATISTA, 2000). É nesse período que é criado o bairro dos Palmares, que chegou a ser um dos maiores da cidade até os fins dos anos 1990 (BUTEL et al, 2012, p.19)

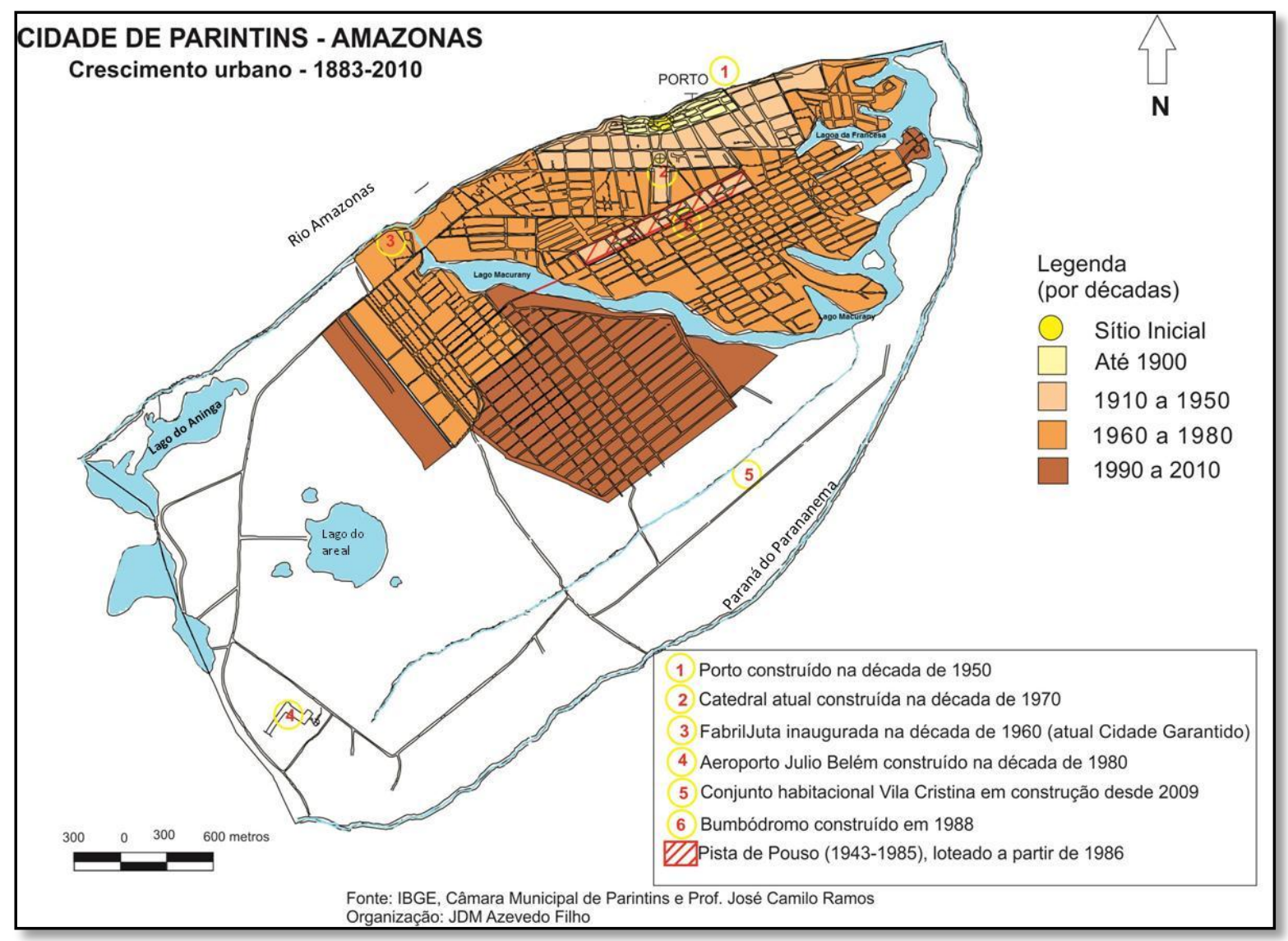

Mapa 3 - Planta: Crescimento Urbano de Parintins 1883 - 2010 
Nos anos 1980, começam a ser construídos os conjuntos habitacionais financiados pelo Governo do Estado, levando a expansão da cidade para o lado oeste. Além da criação do loteamento Djard Vieira, que viria a se tornar bairro (BATISTA, 2000).

A década de 1990 foi um período de grande movimentação populacional. Época de graves crises econômicas no Brasil, associada a um período de grande seca/enchente na região. Ao mesmo tempo, é criado na sede do município um ambiente propício para a migração, devido à construção do Bumbódromo no final da década de 1980 e a divulgação do Festival Folclórico nacionalmente, via mídia televisiva a partir de 1994 (VALENTIN, 2004; BRAGA,2002).

Assim, o que ocorre na primeira década do novo milênio é ainda resultado do crescimento da década de 1990, como a consolidação de bairros novos como o Itaúna e Paulo Correia, os mais populosos atualmente, segundo o Censo 2010 (IBGE, 2011).

Foi em 1966 que teve início o Festival Folclórico de Parintins, promovido por jovens da igreja católica, com apoio da diocese. O evento propiciava a apresentação de quadrilhas e dos bois-bumbás Garantido e Caprichoso.

A historiografia conta que desde o começo do século, mais precisamente em 1913, já havia a disputa entre os dois bois pelas ruas da cidade durante as festividades juninas, chegando, inclusive, a ocorrer enfrentamentos e brigas pelas ruas da cidade. Provavelmente por isso, a direção da igreja católica tenha estimulado a criação do Festival Folclórico (BRAGA, 2002; SAUNIER, 2003; VALENTIN, 2005).

Os primeiros festivais eram realizados em tablados de madeira construídos em local definido pelos promotores.

Segundo Saunier (2003), do $1^{\circ}$ ao $22^{\circ}$ Festival, a realização ocorreu em seis lugares diferentes, o que se alterou com a construção do Bumbódromo, em 1988, para a realização do $23^{\circ}$ Festival Folclórico de Parintins. Desde então o evento acontece no Bumbódromo que recebeu o nome do governador do estado à época, "Amazonino Mendes". No ano de 2012 aconteceu o $46^{\circ}$ festival. 
Hoje o município possui pouco mais de 100.000 habitantes, dos quais 67.000 moram na cidade de Parintins distribuídos entre seus 17 bairros mais a área do Distrito Industrial e de expansão urbana que compreende, assim, toda a extensão da ilha.

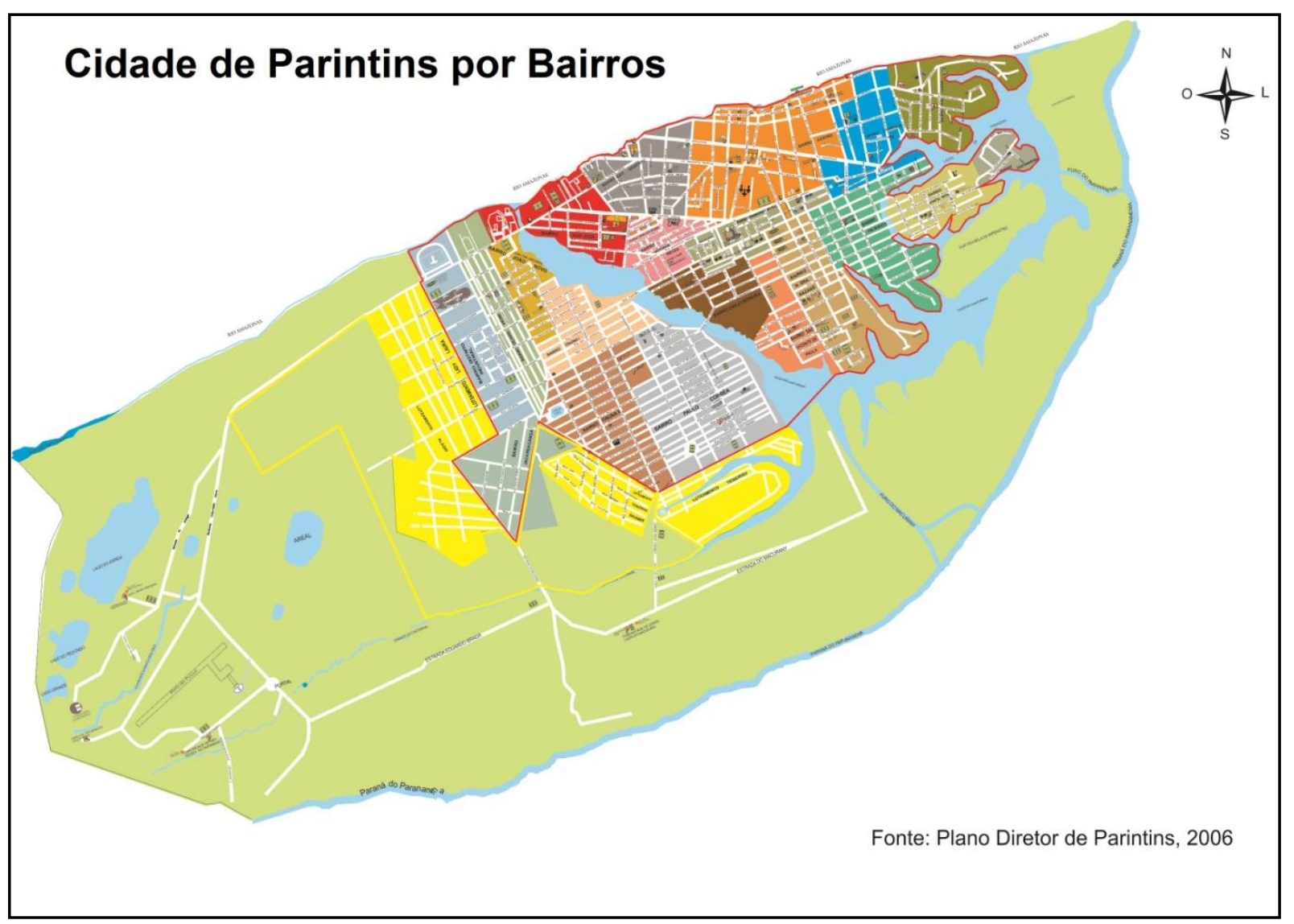

Mapa 4 - Planta: Parintins por bairros - 2012

No dia 16 de março de 2012, em uma "Assembleia Itinerante" realizada em Parintins pela Assembleia Legislativa do Estado, a cidade de Parintins foi declarada "Capital da Cultura e do Folclore" no estado do Amazonas (Lei no 3.729, de 27 de março de 2012, publicada no Diário Oficial do Estado na mesma data). Proposta do deputado estadual parintinense Tony Medeiros, folclorista, um dos itens do Boi Garantido ("Amo do Boi”).

2.3.2 Infraestrutura da cidade 
A cidade de Parintins conta hoje com uma estrutura urbana superior à dos outros municípios do estado, pois é uma cidade Polo (na melhor concepção de polarização de Perroux) como é definida pelo Governo do Estado para as diversas ações como saúde e educação.

A cidade possui todos os níveis de ensino, do básico ao superior: são 21 escolas estaduais de ensino básico; das 168 escolas municipais, 23 estão na sede; um instituto federal, com oferta de ensino médio técnico e dois campi de universidades públicas (IBGE, 2011); uma rede de saúde que atende todo o município e os do entorno, inclusive os municípios circunvizinhos do estado do Pará, nas demandas com grau de complexidade médio; sistema de tratamento e distribuição de água; produção e distribuição de energia elétrica a partir de uma usina termelétrica; bancos, correio, casas lotéricas e correspondentes bancários; significativo comércio; poucas indústrias e serviços de toda ordem.

Ressalvando-se os problemas que se apresentam em todas as cidades, no que se refere ao atendimento público, Parintins pode ser considerada uma cidade referência para o estado.

No tocante ao turismo, possui hotéis e pousadas de níveis variados, além de contar com o apoio de suítes disponíveis em residências que aderiram já há alguns anos ao programa de empreendedorismo Cama e Café, do governo estadual. Possui poucos restaurantes de categoria, mas que atendem a demanda existente juntamente com as várias lanchonetes. Isso sem considerar os outros tantos empreendimentos que se estabelecem por ocasião dos grandes eventos.

O Porto de Parintins, administrado pelo Serviço Estadual de Portos e Hidrovias (SNPH) até 2011, agora é de competência do DNIT através da Administração das Hidrovias da Amazônia Ocidental (AHIMOC), possui capacidade para atender todos os barcos e navios de pequeno calado que trafegam pelos rios da região (figura 4). Com uma nova adequação, ainda sem data prevista, espera-se que os transatlânticos também possam ancorar diretamente no Porto. 
Figura 4: Porto de Parintins, maio/2013.

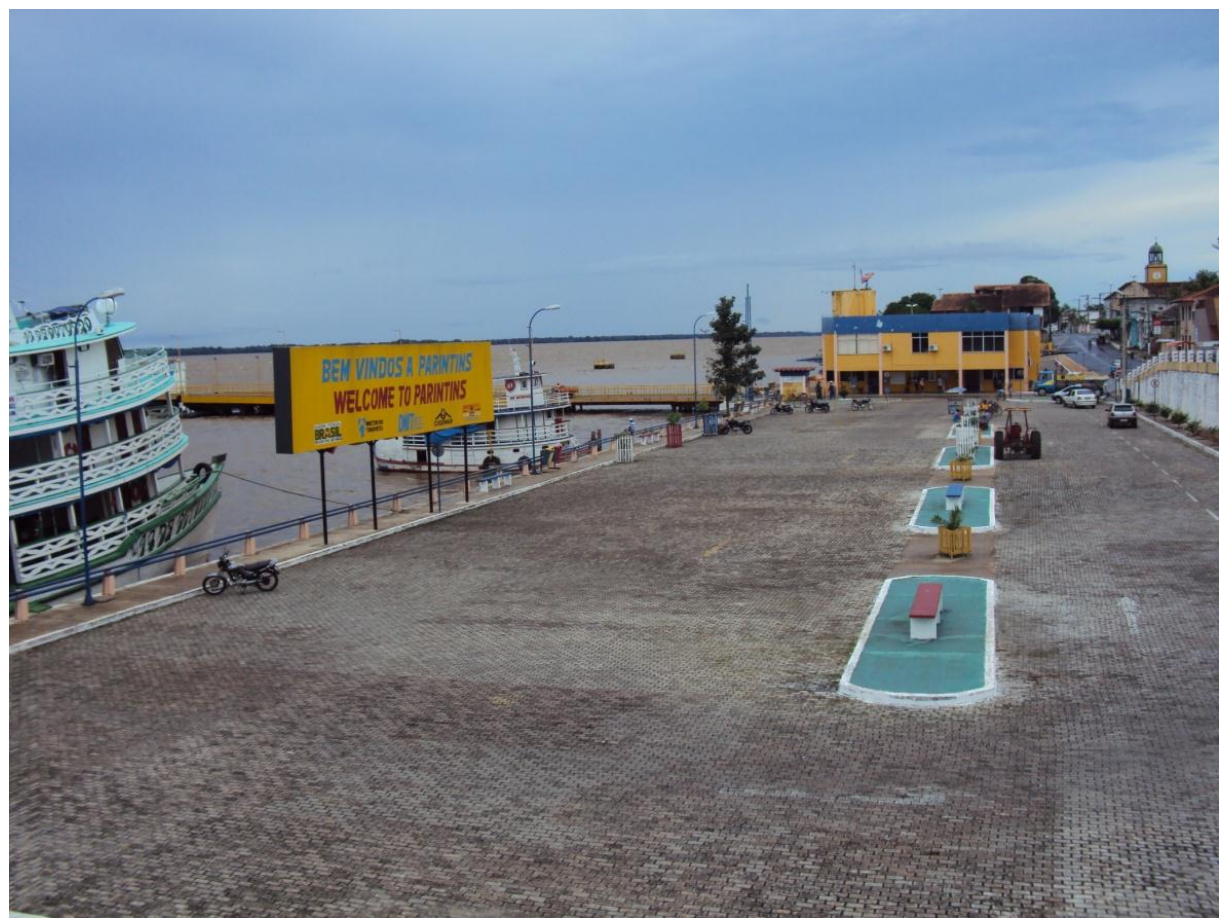

Fonte: acervo do autor.

$\mathrm{O}$ aeroporto de Parintins atende as necessidades da demanda cotidiana da cidade e recebe outros aviões, inclusive aeronaves maiores, como o Boeing 737, fretadas para o período do festival (figura 5). Sua administração está a cargo da Prefeitura Municipal. Tem voos direto exclusivamente para Manaus.

Figura 5: Aeroporto Júlio Belém, Parintins, Amazonas, maio/2013
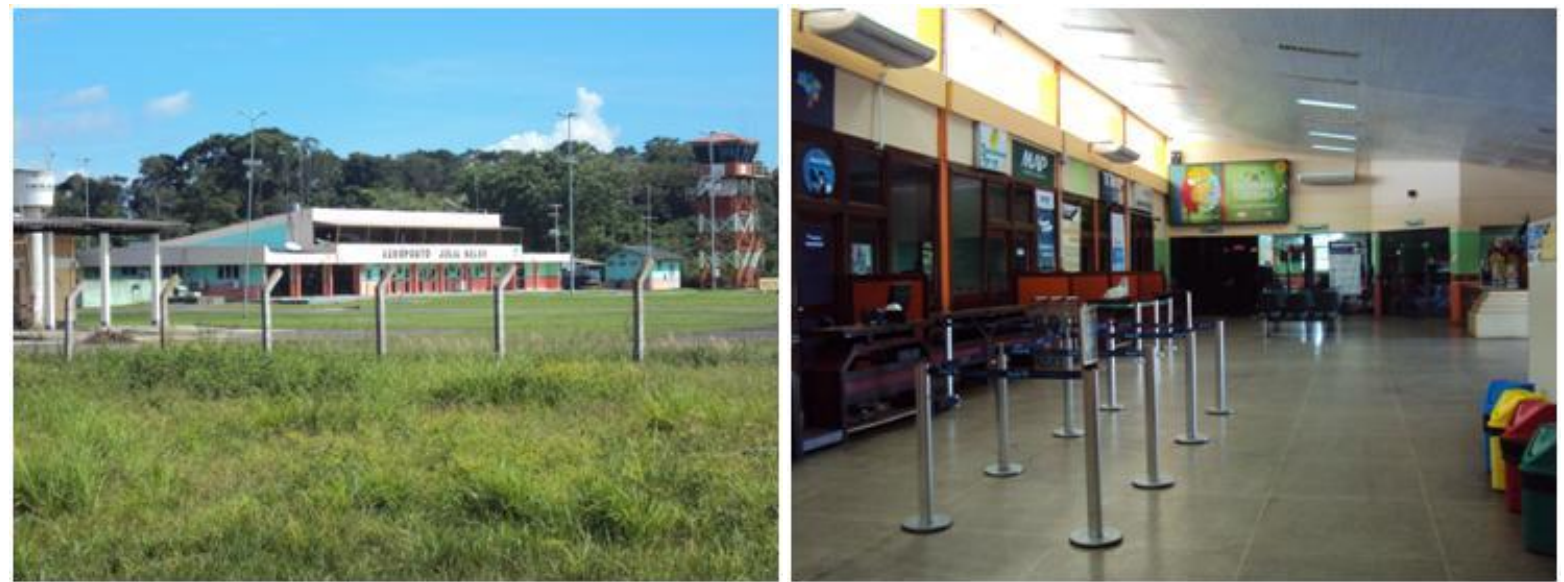

Fonte: Acervo do autor. 
Olhando o passado e o presente de Parintins pode-se perceber o encantamento dos viajantes pelo lugar. Além de um ponto de parada entre a viagem de Manaus a Santarém ou Belém a cidade sempre ofereceu o mínimo de infraestrutura para atender aos viajantes. Atualmente ganha característica de cidade média, dentro do contexto regional. Além disso, a consolidação do Festival Folclórico tornou a cidade uma referência do turismo regional e nacional. O festival dos Bois-Bumbás é o grande ícone da atualidade, mas até que ponto isso impede que outras manifestações culturais e ambientais se transformem em opções turísticas para a cidade e para o município? Parintins possui uma pequena infraestrutura para atender os turistas, tanto durante o festival como durante o ano todo e outros eventos, mas é preciso muito mais do que isso para o município um lugar turístico. 


\section{CAPITULO III}

\section{PARINTINS - BOI-BUMBÁ E OUTRAS PRÁTICAS TURÍSTICAS LOCAIS}

O Festival de Parintins já foi bastante estudado sob diversos ângulos, sendo que a preocupação maior foi entender a festa, seu rito e suas relações, principalmente num olhar sociológico e antropológico. Olhar o Boi-bumbá na perspectiva da sua geografia ainda não se

tem notícias. É possível que essa deficiência esteja na dificuldade de interpretá-lo a luz do conceito tradicional da geografia, ou seja, uma ciência que estuda o espaço geográfico, obra do trabalho humano. Somente essa concepção não possibilita entender uma atividade que envolve um grande movimento de pessoas e ideias num fazer e desfazer constante que é o festival. Nesse sentido, uma leitura geográfica a partir da interpretação do fenômeno turístico pode conduzir a uma primeira aproximação, mas também, limitada. O turismo é uma atividade econômica, mas também um fenômeno social e político, resultado de inter-relações entre os diversos agentes que o fazem acontecer, seja o Estado, os agentes turísticos, os empresários, mas, principalmente, as pessoas do local e os turistas. Esses sim devem ser considerados naquilo que os possibilita transformar e modificar o espaço para viabilizar o turismo.

\subsection{Parintins cidade do turismo}

O município de Parintins apresenta, desde 1980, um crescimento populacional significativo. É desse período o registro de que a população urbana superou a população rural. Hoje, o município é considerado o segundo em população do Estado e o quarto na distribuição do fundo de participação dos municípios - FPM. 
Tabela 2 - População de Parintins e taxa de crescimento entre 1960 e 2010

\begin{tabular}{c|c|c}
\hline Ano & Total & Cresc. (\%) \\
\hline 1960 & 37.525 & - \\
\hline 1970 & 38.086 & 1,49 \\
\hline 1980 & 51.381 & 34,91 \\
\hline 1991 & 58.783 & 14,41 \\
\hline 2000 & 90.150 & 53,36 \\
\hline 2010 & 102.033 & 13,22 \\
\hline
\end{tabular}

Fonte: IBGE, Censos 1960, 1970, 1980, 1991, 2000 e 2010

Organização: J. D. M. Azevedo Filho

Essa condição o destaca dentre os demais municípios, pois lhe possibilita manter uma estrutura administrativa significativa para os padrões da região.

Tal destaque é ainda superado, quando o enfoque é o Festival Folclórico de Parintins, realizado atualmente no último fim de semana do mês de junho (sexta, sábado e domingo). São três noites de apresentação dos dois grupos folclóricos mais importantes do Amazonas: os Bois-Bumbás Garantido e Caprichoso. A cidade se agiganta pela presença dos turistas e de todo o aparato do Estado que vem dar suporte à Prefeitura.

\subsubsection{O Festival dos Bois-Bumbás Garantido e Caprichoso}

O Festival Folclórico de Parintins se assemelha a outros eventos de grande porte como a Festa de Peão (Barretos-SP), Oktoberfest (Blumenau-SC) e mesmo o Carnaval (ou carnavais, pelo Brasil a fora). Essa atividade turística de evento se caracteriza pelo seu preparo ao longo do ano, que se aprofunda nos três últimos meses e culmina com a apresentação em três dias (AMARAL, 1998). 
Desde o fim do evento, no domingo, começam os preparativos para o Festival do próximo ano. A definição do tema e das toadas dos bois ${ }^{2}$ são definidas antes do fim do ano pela Comissão de Arte das duas agremiações. A partir de março ou abril, geralmente, após os festejos do "Carnailha" (carnaval de rua) de Parintins, começam os trabalhos mais intensos de montagem das alegorias e confecção das fantasias e adereços. Os ensaios em ambos os "currais" (sede das agremiações, onde se realizam os eventos e festas) se intensificam, com a presença de brincantes e do público em geral, admiradores do Boi preferido, que aprendem as toadas e coreografia da dança. A cada ano, as coreografias ganham alguma variação para acompanhar o enredo das toadas.

Figura 6: Festas de Boi pelas ruas de Parintins
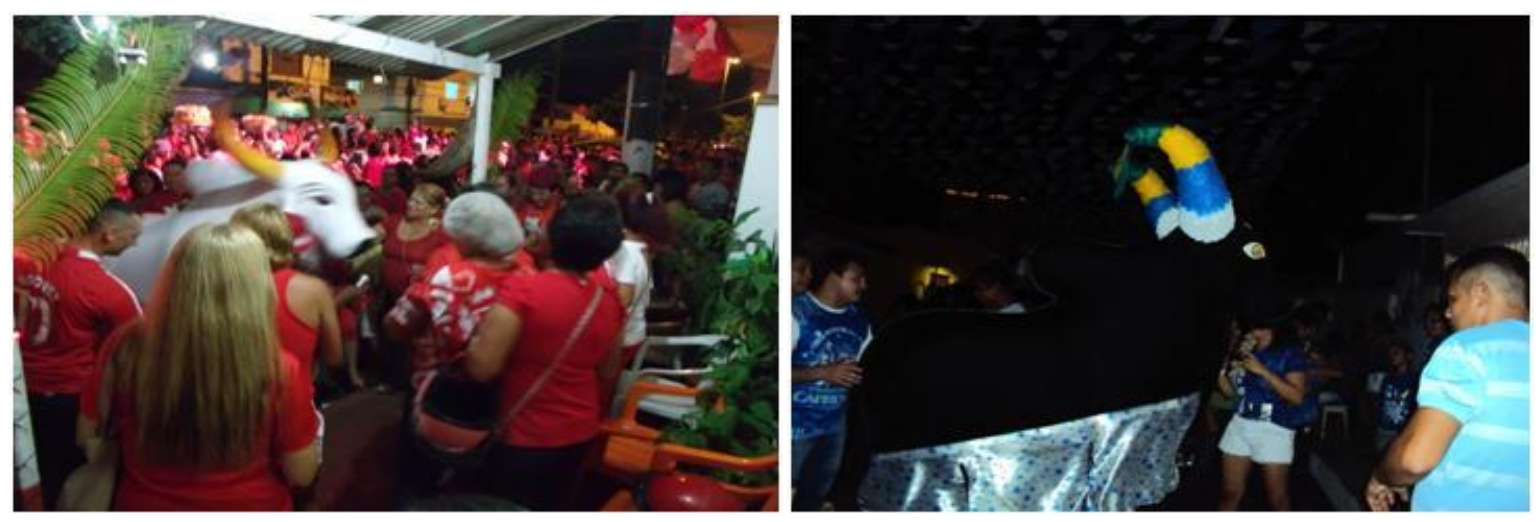

Fonte: acervo do autor

Nesse período, obedecendo a um calendário tradicional, cada Boi realiza festas pontuais em seus currais e pelas ruas da cidade (quadro 1). Muitas delas são coincidentes de datas, todavia as agremiações obedecem aos limites do seu território. Tal limite é teórico, factível apenas na época do festival e das festas de rua: o lado direito da ilha, quadrante leste, é do Boi Caprichoso, de cor azul, e o lado esquerdo do Boi Garantido, de cor vermelha (figura 6. O ponto de referência dessa divisão espacial é a praça da Catedral de Nossa Senhora do Carmo.

\footnotetext{
2 O termo "bois" ou Boi será utilizado neste trabalho como sinônimo de grupo folclórico, no caso, as duas Associações Folclóricas de Parintins, o Garantido e o Caprichoso.
} 
Quadro 1 - Festas tradicionais dos Bois de Parintins precedentes ao Festival (2011-2012)

\begin{tabular}{|l|l|l|}
\hline \multicolumn{1}{|c|}{ Garantido } & \multicolumn{1}{c|}{$\mathbf{2 0 1 1}$} & \multicolumn{1}{c|}{ 2012 } \\
\hline Lançamento do CD & Março/abril & 30 de abril \\
\hline Alvorada do Boi & 30 de abril/01 de maio maio \\
\hline Festa de Santo Antonio & 12 de junho & 12 de junho \\
\hline Festa de São João/Promessa/de rua & 24 de junho - ladainha & $\begin{array}{l}24 \text { de junho }- \text { (ultimo Boi } \\
\text { de Rua) }\end{array}$ \\
\hline Festa Vermelho e Branco & 29 de maio - final do mês & \\
\hline Morte do boi & 17 de julho & 17 de julho \\
\hline \multicolumn{1}{|c|}{ Caprichoso } & & 30 de abril \\
\hline Lançamento do CD & 30 de abril & 30 de abril \\
\hline Primeiro ensaio & $1^{\circ}$ de abril & 28 de junho \\
\hline Festa Azul e Branca & 28 de maio & Maio \\
\hline Apresentação dos itens & Maio & 25 de junho \\
\hline Boi de Rua & $\begin{array}{l}\text { Antes do ensaio geral - 18 de } \\
\text { junho }\end{array}$ & 23 de junho \\
\hline Ensaio geral & 18 de junho & \\
\hline
\end{tabular}

Fonte: Baseado em informações de jornais e revistas locais

As festas citadas acima foram baseadas nas realizações do ano 2011 e 2012. A maioria das festas do Boi Garantido é fixa, pois compreendem datas comemorativas: Festa de São José, santo que dá nome ao bairro onde o Boi foi fundado e Dia dos Namorados - Santo Antonio e São João. No caso do Boi Caprichoso, a agremiação estabelece um calendário das suas festas a cada ano, sempre na mesma ordem.

A um mês do início do Festival, a cidade se transforma, pois a movimentação turística se intensifica. É nesse período que os hotéis começam a receber seus primeiros hóspedes, geralmente representantes das empresas contratadas para viabilizar a infraestrutura do evento, como obras públicas e energia elétrica e também das empresas privadas que atuam e comercializam durante o festival. É o caso da empresa que detém o direito de transmissão e outras, patrocinadoras do Festival como a Coca-Cola e Banco Bradesco.

As obras de infraestrutura também se intensificam, concentrando-se na parte mais central da cidade com limpeza, pintura de meio fio, tapa buraco e recapeamento asfáltico quando necessário, iluminação pública, sinalização de trânsito e turística. Geralmente, o Bumbódromo, palco do evento, com capacidade para 12,5 mil espectadores entre arquibancada e camarotes também recebe manutenção e reformas. 
Os sistemas de segurança e saúde são reforçados. Os hospitais recebem equipamentos e recursos para atender a demanda do período, ao mesmo tempo em que é designada equipe médica da capital para complementar o quadro local e ambulâncias (inclusive com UTI móvel e aérea) são disponibilizadas para a cidade.

A Guarnição de Policia Militar recebe soldados e viaturas para atender as necessidades do momento. No ano de 2011 foram 700 soldados a mais para atuar na segurança e prevenção de crimes e acidentes de trânsito. Equipes do Departamento de Trânsito (DETRAN-AM) também colaboram com a ação preventiva no trânsito da cidade.

A Polícia Civil, que tem um contingente mínimo no seu dia a dia foi reforçada, nesse mesmo ano, com mais 61 homens, dentre os quais delegados, peritos criminais, escrivães e investigadores. Até uma equipe da Polícia Federal é designada para, no período, atuar no controle dos portos e aeroporto.

O Corpo de Bombeiros é outro serviço reforçado durante o Festival. O Batalhão local, constituído por 22 membros, foi reforçado em 2011 com 135 bombeiros e 20 viaturas.

Toda essa organização é estabelecida por um órgão gestor criado pelo governo do Estado com o apoio da Prefeitura local, o Gabinete de Gestão Integrada (GGI) que tem a incumbência de coordenar as ações de controle dos serviços e prevenção dos acidentes durante o festival.

É válido ressaltar que todo o equipamento, como viaturas, carros, caminhões, ambulâncias etc., são transportados para a cidade em balsas, visto não haver estradas que liguem Parintins aos outros municípios e à capital. As pessoas envolvidas nesta ação são transportadas de barco ou de avião.

\subsubsection{Nem só de Boi vive Parintins: religiosidade, carnaval e cruzeiros}

A atividade turística em Parintins se baseia no Festival Folclórico, no mês de junho. Todavia, merece destaque o grande número de fiéis católicos que vêm à cidade para a Festa da Padroeira Nossa Senhora do Carmo, evento realizado entre os dias 6 e 16 de julho, com arraial, círio, missas e procissão. Nos últimos anos, tem havido inclusive o fretamento de aviões para atender essa demanda. Barcos velozes, denominados regionalmente de "a jato", 
que atuam no transporte de passageiros do município para a capital e vice-versa também realizam viagens extras no período da festa.

Figura 7- Festa de Nossa Senhora do Carmo, Parintins, julho/2012

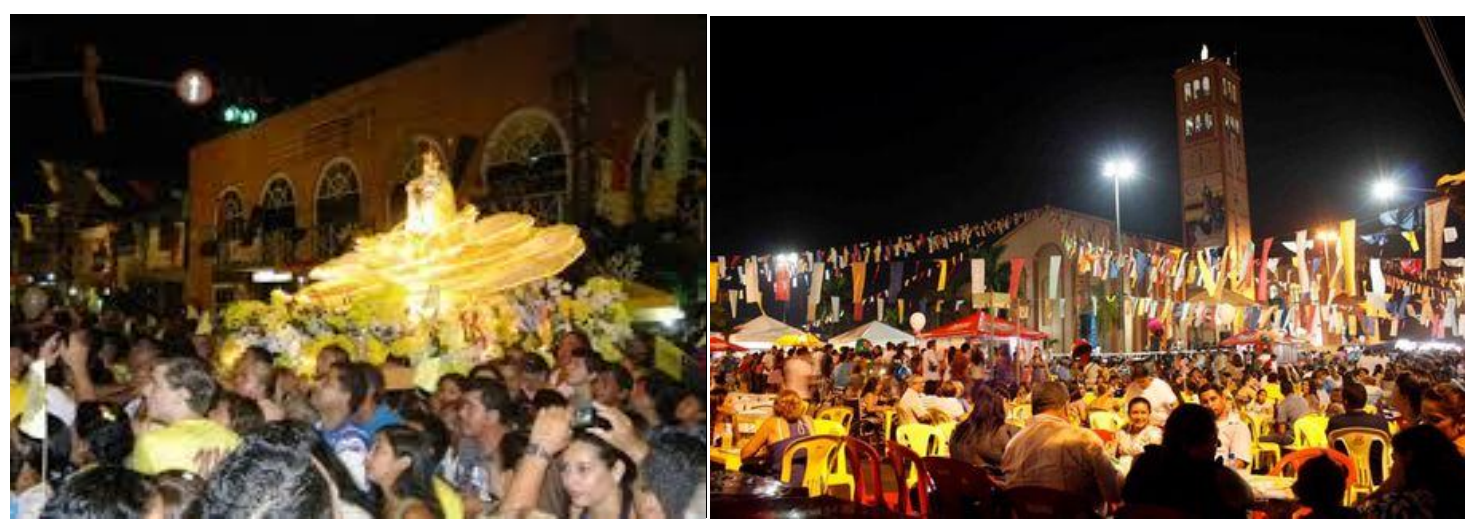

Fonte: Jornal da Ilha e Jornal A Critica, julho de 2012 (divulgação)

A festa se caracteriza pela realização do círio que abre o evento sacro realizado em torno da Catedral de Nossa Senhora do Carmo e missa toda noite. Um grande arraial é promovido pela igreja, com comidas típicas, bebidas, barracas que vendem brincadeira, produtos e lembranças da festa. A grande promoção da festa é o famoso Bingo da Santa, com valiosos prêmios que são sorteados, ou bingados, toda noite, até o último dia quando o prêmio é o mais valioso. Na noite de encerramento é feita a procissão de Nossa Senhora do Carmo que reúne um expressivo número de fies, chegando, conforme os jornais locais, a 20 mil pessoas.

As atividades turísticas em torno de eventos religiosos têm sido estimuladas nos últimos anos pelo governo. Recentemente o governo federal, através do Ministério do Turismo, abriu um edital para apoiar esse tipo de evento. Apesar de sua importância na região, o evento religioso é coordenado pela Diocese de Parintins, com pouca interferência do governo municipal. Apesar disso, é inegável o apoio do Poder Público ao evento, seja na preparação das áreas públicas, segurança, limpeza etc.

Outro evento muito importante é o Carnailha, carnaval de rua realizado entre o sábado e a terça-feira de carnaval. O palco é construído em uma das principais vias da cidade, a rua Paraíba, atrás do Bumbódromo (figura 8). Nele desfilam blocos irreverentes, divididos em grupos A, B e Especial, cada um com seu regulamento. Nesse evento também, o número 
de serviços públicos é ampliado e o quantitativo de turistas, conforme estimativa da Prefeitura é de 15 mil pessoas (PMP). Mais de 30 mil pessoas participam do evento.

O Carnailha, por outro lado, apesar de ser promovido pela Liga dos Blocos Carnavalesco (LIBLOC), tem todo o apoio do Governo do Estado e da Prefeitura de Parintins, inclusive com apoio financeiro para os Blocos de Carnaval para prepararem seus desfiles. Mesas, camarotes e arquibancada especial são vendidos e as demais arquibancadas são livres para a população e turistas. Os blocos, por outro lado, vendem camisas, ou como são chamadas aqui, "tururi", para os que querem brincar na avenida acompanhando o bloco. Os blocos descem a avenida, uns 150 metros de percurso, apresentando apenas um carro alegórico, que são maiores e mais bem enfeitados e equipados de acordo com a que pertence. O grupo especial apresenta os blocos mais importantes e maiores, com a presença de vários destaques e brincantes.

Figura 8: Carnailha, carnaval de Parintins, Amazonas, 2013.

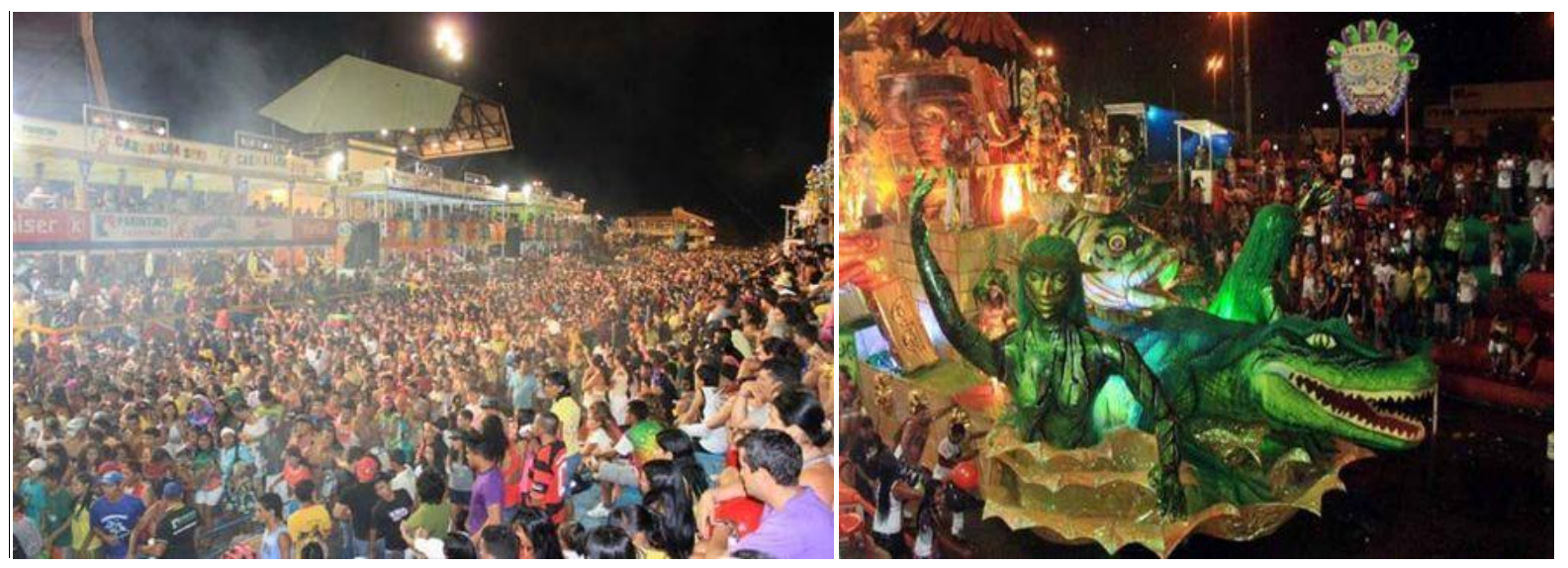

Fonte: Jonas Santos, Jornal A Crítica, 06.03.2013

É comum as pessoas comprarem vários tururis, de diversos blocos, e descerem várias vezes a avenida do samba.

O fluxo diferenciado de turistas se dá pela visita dos grandes navios transatlânticos que cruzam o rio Amazonas de sua foz até Manaus e vice-versa. Os grandes navios fundeiam em frente à cidade e os passageiros saem em pequenas embarcações motorizadas até o Porto da cidade. Geralmente, as empresas de viagem já preparam uma programação em terra e vendem esse roteiro aos interessados. A excursão se baseia em passeio pela cidade e uma 
apresentação no curral do Boi Garantido ou do Boi Caprichoso, alternadamente, durando a programação, que dura em média 2 horas. Os navios ficam à frente da cidade de 6 a 10 horas.

Atualmente, uma empresa privada ligada ao turismo, construiu um salão de eventos próximo ao porto da cidade, e tem realizado as apresentações dos Bois neste local.

Os passeios pela cidade e até mesmo a condução dos turistas até os currais são feitos em ônibus, mas principalmente em triciclos à tração humana.

Os tricicleiros são trabalhadores que atuam no transporte de passageiros e carga de pequeno porte na cidade. O triciclo é uma descaracterização de uma bicicleta, à qual é adaptada uma bagageira feita de estrutura metálica composta por mais duas rodas (figura 9). São vistas frequentemente pelas ruas da cidade fazendo principalmente o transporte de cargas de toda ordem e passageiros. No desembarque nos portos, quando se chega à cidade, é comum o uso desse meio de transporte.

No período do Festival Folclórico e na passagem dos turistas de transatlânticos, os triciclos são enfeitados e cobertos com palhas regionais ou simplesmente com lonas de plástico. Durante o Festival são decorados conforme a cor do Boi preferido do tricicleiro e chama a atenção dos seus admiradores. Já na passagem dos transatlânticos os adereços regionais, como palhas, cipós e artesanatos, chamam mais a atenção. Atualmente, esses trabalhadores estão organizados na Associação dos Tricicleiros de Parintins.

Figura 9: Triciclo em dia de visitação de turistas de cruzeiros
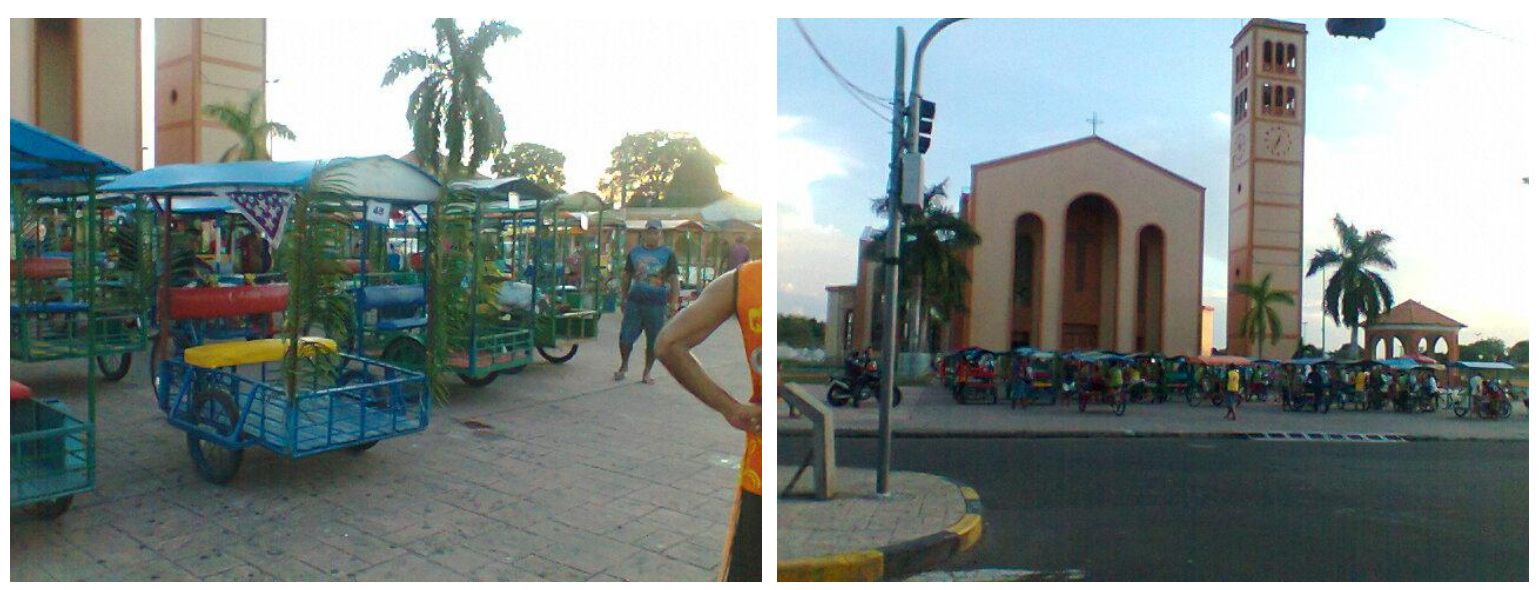

Fonte: acervo de JDM Azevedo Filho 
Diferentemente do que ocorre no período do Festival Folclórico de Parintins, no período dos transatlânticos não acontece uma "preparação" da cidade. Não há equipe de segurança, saúde, trânsito, pinturas ou reformas das ruas e instalações públicas. Apenas as equipes contratadas adornam a entrada do porto, contatam a Associação dos Tricicleiros, acertam com as agremiações a apresentação do Boi e outros serviços necessários. Barracas de artesanatos são colocadas na área do Porto da cidade e nas proximidades. As despesas são pagas em dólares americanos.

Segundo dados obtidos junto aos trabalhadores, um vendedor de artesanato chega a ganhar por temporada de transatlânticos de 100 a 800 dólares. Os tricicleiros, entre 20 e 60 dólares. Os artesãos afirmam que a atividade já foi bem melhor, visto que antes de 2005 os transatlânticos ancoravam no antigo porto, sendo possível o desembarque de grande número de turistas, inclusive os com dificuldade motora. Alguns desses compravam o acesso aos currais dos Bois e eram transportados para os locais de apresentação. Os demais ficavam circulando pelo Centro da cidade, comprando artesanatos, bebendo, tirando fotografias. Conforme afirmam os artesãos, nesse período era possível ganhar até 5.000 dólares por temporada.

O mesmo não acontece hoje em dia, pois os transatlânticos são fundeados no meio do rio, de onde os passageiros são transportados em botes motorizados apropriados pertencentes ao próprio navio. Devido a isso, poucos são os que, além de virem para as atividades já acertadas, ficam circulando pela cidade. Há grande dificuldade para o embarque e desembarque no porto da cidade, sem falar do movimento e velocidade das águas do rio Amazonas que intimida muita gente.

Os agentes turísticos contratados em terra para o atendimento aos turistas de transatlânticos não são ligados aos órgãos públicos. São, geralmente, agentes de viagem e empresários do turismo com forte conexão com as grandes agências de viagem que controlam o turismo de transatlânticos pela Amazônia.

A rota dos cruzeiros, em geral, segue um caminho pré-determinado. Partem da Flórida, nos Estados Unidos, das cidades de Fort Lauderdale e de Miami, seguindo uma rota pelo Caribe e entrando no Brasil pelo rio Amazonas (Figura 10). As paradas no território 
brasileiro são geralmente em Macapá, Belém, Santarém e Manaus. De forma intermediária e alternadamente, fazem paradas em Alter do Chão (no estado do Pará), Boca da Valéria e Parintins, podendo isso acontecer na subida ou na descida do grande rio.

Frequentemente, as rotas diferem conforme o percurso e o tempo, há viagens com mais de 50 dias, por exemplo. O rio Amazonas está na rota de muitos transatlânticos com paradas em Macapá, Santarém, Manaus e portos intermediários, como Parintins e Boca da Valéria. Alguns roteiros da viagem que incluem a incursão pelo rio Amazonas se dá no trecho do porto de origem até Manaus e de lá retorna até o ponto de origem ou outro ponto final. Alguns roteiros, por outro lado, estabelecem retorno e início a partir de Manaus, são duas excursões com passageiros diferentes que revezam em Manaus com chegada e retorno de avião. Nesse caso, para-se em Parintins e Boca da Valéria na ida e na volta.

Figura 10: Roteiros de dois cruzeiros com destino à Manaus
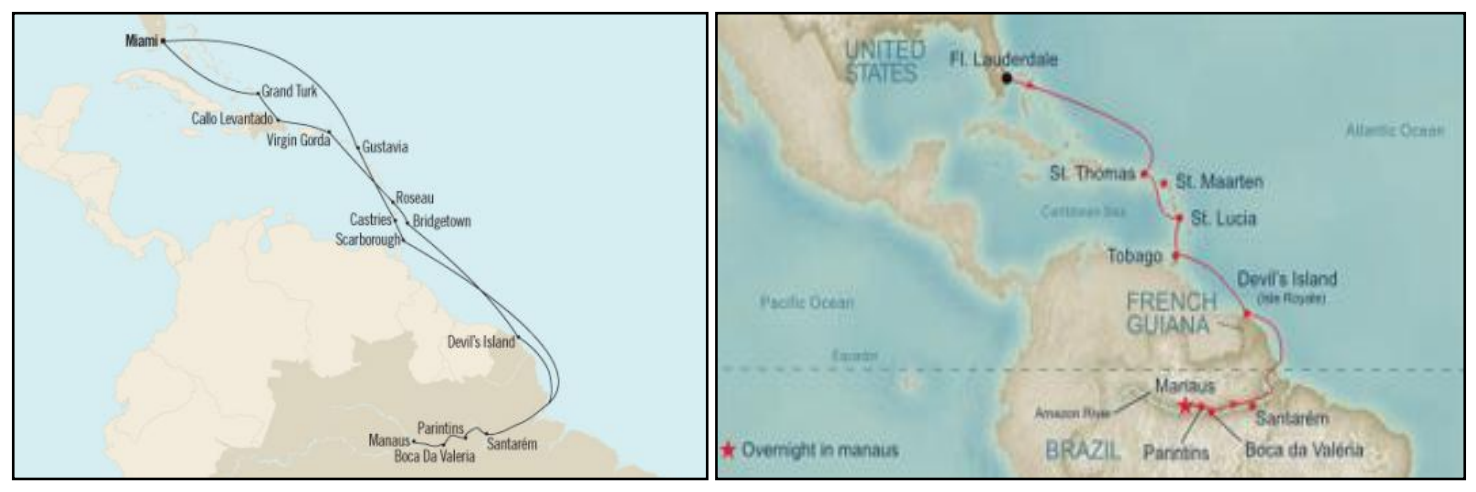

Fonte: Agências de viagem: http://www.cruisecompete.com

Outros roteiros são oriundos da Europa com saída frequentemente do porto de Amsterdam, na Holanda, seguindo para o Caribe, depois para o Amazonas.

\subsection{A imagem e o imaginário no turismo de Parintins em Manaus}

A verdade é que o turismo em Parintins está ligado à força do Festival em atrair turistas de outras partes do estado, do país e do mundo. Os primeiros a se envolverem com o Festival e se interessarem pela grande festa foram os moradores dos municípios vizinhos e da capital, Manaus. 
O crescimento econômico da cidade de Manaus, nos anos 1970, ligado à implantação da Zona Franca de Manaus, em 1968 e do seu parque industrial nos anos subsequentes, proporcionou um crescimento populacional não conhecido na capital amazonense. Nem mesmo o boom da borracha, no final do século XIX e início do século XX imprimiu tão acelerado crescimento, tendo em vista que a imigração de trabalhadores, principalmente nordestinos, se faziam em direção aos seringais, instalados em distantes rincões do interior da Amazônia. Manaus e Belém eram importantes entrepostos tanto para o recebimento e distribuição dessa leva de migrantes, como também, com a instalação de lojas aviadoras, bancos e casas comerciais, eram o destino da borracha colhida na região e depois enviada para os centros consumidores, principalmente a Europa.

Manaus, em 1970, possuía uma população urbana de 283.685 habitantes, chega a 630.000 em 1980 e em 1991 já supera a casa do milhão de habitantes, vivendo um período de “explosão demográfica” (AZEVEDO FILHO, 2004). Essa população vinha, principalmente, do interior do estado, mas também de estados vizinhos, como o Pará e Rondônia. Segundo estudos sobre as migrações para Manaus realizada nos anos 1980 e publicado em 1990, pela Fundação Joaquim Nabuco, os imigrantes eram em sua maioria $(49,0 \%)$ do próprio estado do Amazonas, sendo que as maiores contribuições estavam em seis municípios: Careiro, Coari, Itacoatiara, Manacapuru, Parintins e Tefé. Outro grande fornecedor de imigrantes é o estado do Pará $(15,9 \%)$, seguido do Ceará $(8,5 \%)$. As causas para a migração são primeiramente por questões econômicas: busca de trabalho e melhores condições de vida; logicamente, num processo de atração-expulsão, no lugar de origem carecia-se de todo um conjunto de fatores, como infraestrutura, emprego, estudo etc (MELO; MORVAN, 1990).

A população parintinense migrada para Manaus deve ter sido a primeira clientela para o festival de Parintins, nos anos 1980, principalmente, depois da construção do Bumbódromo, em 1988. A partir de 1994, com o incremento da divulgação do Festival pela televisão, uma parcela maior da população manauara vem para Parintins, bem como outros municípios mais próximos. Esse período também é a fase da grande crise na ZFM propiciada pela abertura econômica de 1990, no Governo Collor, que vai abalar a base da estrutura da ZFM que é a política protecionista do mercado interno e os incentivos fiscais para importação. Nessa fase da história econômica do estado do Amazonas percebem-se correntes migratórias inversas, em direção ao interior. Cidades como Parintins tiveram forte crescimento populacional na década em referência. 
Outro fator que vai atrair a população de Manaus para o Festival são as festas de boi, ou ensaios, promovidas pelas duas agremiações na capital, que servem para divulgar o evento, ensaiar as toadas e as novas coreografias e arrecadar recursos para cada agremiação. Em Manaus os ensaios eram realizados em locais diferentes para cada Boi, no entanto, a partir de 2003, depois de observar-se uma queda na frequência de participantes nos anos anteriores, as duas entidades que promovem os Bois em Manaus, o Movimento Amigos do Garantido (MAG) e o Movimento Marujada, do Caprichoso, decidiram por centralizar os ensaios no Centro de Convenções do Estado do Amazonas, o sambódromo amazonense. Logo após o carnaval, nos meses que antecedem o Festival, realizado no último fim de semana do mês de junho, os ensaios acontecem praticamente no mesmo ritmo que em Parintins.

Ferreira e Braga (2004) acompanharam essa movimentação dos ensaios dos Bois de Parintins em Manaus, preocupados em fazer uma descrição etnográfica e uma análise da experiência cultural assumida pela população nos ensaios dos bois-bumbás em Manaus. Para eles, as pessoas da cidade de Manaus têm conhecimento do Festival e dos bois-bumbás Garantido e Caprichoso através de discos, das músicas transmitidas pelas rádios locais à época da chamada temporada do boi (período de março a meados do mês de junho), por meio de jornais e revistas. Nos ensaios são aprendidas as novas toadas, coreografias, passos de dança e promovidas múltiplas formas de sociabilidade entre os grupos de jovens, que têm presença majoritária nos ensaios. Nos currais dança-se à vontade, e é lá que os brincantes aprendem as letras e as músicas das toadas que serão apresentadas nos três dias do Festival de Parintins. Essas festas chegam a reunir cerca de quinze mil pessoas por evento, animadas por músicos, ao som contagiante da toada, um ritmo composto de compasso binário, fundamentado na percussão, com acompanhamento de instrumentos melódicos, como: violão, charango, teclado (sintetizador), bateria; além de coro e bailarinos, neste caso, aqueles que ensinam as coreografias e os passos de dança. Há a preocupação de se cantar nos ensaios as toadas novas do ano, gravadas em um CD/DVD e agora também em Blue Ray, com dezoito músicas, tocadas por bandas credenciadas pelos próprios bumbás. Nas últimas semanas que antecedem o grande Festival, o público presencia a aparição de alguns dos "itens do boi”, como a cunhã-poranga, o pajé, a rainha do folclore, a porta-estandarte, que tornam a festa ainda mais emocionante. $\mathrm{O}$ cantor de toadas é chamado de levantador de toadas. O levantador é o líder da cantoria, uma espécie de termômetro entre o show que cada banda apresenta e o público presente no ensaio, sendo, portanto, "umas das figuras essenciais, cuja arte consiste 
em se manter em permanente sintonia com seu público" (FERREIRA; BRAGA, 2004, p. 139144)

É dessa forma que se cria a imagem do festival e o imaginário se cria naqueles que ainda não conhecem o mesmo e se renovam nos parintinenses residentes em Manaus e naqueles que não perdem um festival. Claro que tudo isso apoiado pela força da mídia, que com o apoio promocional de diversas empresas locais e nacionais, propiciam a divulgação do evento. Pelo menos no Amazonas o Festival Folclórico de Parintins continuará a atrair contingente cada vez maior da população, cabe saber se os demais estados se interessam pelo evento, visto acontecer no mês de junho, momento de muitos eventos juninos em várias partes do país, e de ser a abertura do período de alta temporada do meio do ano e os destinos turísticos são outros.

\subsection{Turismo em Parintins, seus atrativos e suas características}

A prática do turismo em Parintins ocorre há muito tempo. Desde tempos coloniais o lugar já era ponto de parada obrigatória dos que viajavam pelo rio Amazonas. Não podemos esquecer que a cidade de Parintins é um dos pontos modais, na viagem entre Belém e Manaus. Quem viaja neste sentido, para o interior da Amazônia, via rio Amazonas tem a possibilidade de passar em cidades como Breves, Gurupá, Almerin, Monte Alegre, Santarém, Óbidos, Juruti, Parintins e Itacoatiara. Pedro Teixeira e depois outros colonizadores investidos de poder ou santidade e cientistas que vieram estudar a Amazônia, todos passaram por Parintins.

Por ser apenas lugar de parada para abastecimento, descanso (repouso) e coleta de lenha para as embarcações não representa necessariamente uma atividade (atrativo) turística, mas o lugar deixa a impressão de desbravamento, de mais um espaço conhecido, que vai ser lembrado, relatado, desenhado ou fotografado, dependendo da época, um lugar que deixa marca na memória.

Com certeza a Parintins de hoje continua a deixar marcas naqueles que apenas passam, como naqueles que ficam, nem que seja por algumas horas, como é o caso dos 
turistas dos transatlânticos, sejam passageiros ou tripulantes, e que levam um pouco desse lugar turístico nas lembranças (souvenires), na fotografia ou somente na memória.

Vários autores já se dedicaram ao estudo do Festival Folclórico de Parintins ou da festa que envolve a rivalidade entre os dois Bois-bumbás, Caprichoso e Garantido (BRAGA, 2001; VALENTIN, 2005).

Braga (2001) em “Os Bois-Bumbás de Parintins”, que é resultado da sua tese de doutorado, faz uma profunda descrição e análise antropológica e social da festa dos Boisbumbás de Parintins. Antes faz uma contextualização histórica da evolução da cidade e do próprio festival, para depois interpretar as diversas manifestações dos traços (etnográficos) do Boi, o auto do boi, a trama, o rito, o mito, os signos, as manifestações religiosas e culturais para, em fim, chegar a "ideologia do folclore". Essa ideologia estaria inscrita no corpo dos brincantes, no batuque, no canto e na dança. Mas, o autor acrescenta que ela veicula uma outra, a "ideologia de mestiçagem", ou seja, uma forma simbólica de ignorar os conflitos sociais, de classe e étnicos encenados na festa dos bois que chama todos para brincar, confundindo-os com a ideia de mestiçagem. Em Parintins, diferentemente, de outros lugares onde se dança o boi, uma nova versão é concebida, quando se apropria da imagem do índio e da Amazônia para criar uma identidade regional "cabocla".

Valentin (2005) descreve o festival dos Bois com um olhar mais artístico e voltado para uma análise sistemática para a disputa entre os "contrários", o Garantido e o Caprichoso. Para o autor é na rivalidade dos Bois que se faz a festa, é a "força propulsora" que instiga as duas agremiações à renovação e à superação. É essa rivalidade que dá a identidade do parintinense e de todos que brincam a festa, pois ela se fixa no imaginário das pessoas e da geografia local. É ao transformar esse possível conflito em festa que a rivalidade entre os dois Bois passa a ser um objeto de estudo. Segundo o autor, ao longo dos anos, o festival foi aperfeiçoado, incorporou regras, fazendo com que os "contrários", os Bois de Parintins, passassem de uma simples festa de rua para se transformar num evento monumental, não só amazonense, mas mundial.

O turismo em Parintins é composto basicamente por atividades pontuais que são denominadas turismo de evento. O Festival Folclórico de Parintins, o maior produto do turismo parintinense, é uma festa constituída principalmente pelos desfiles das duas agremiações de Bois-bumbás, o Garantido e o Caprichoso. 
O Festival dos bois se notabilizou a partir de 1994 com a divulgação em canal aberto do evento. Neste ano grande patrocinadores foram incorporados ao evento, principalmente uma emissora de televisão, a Coca-cola, uma cervejaria e um grande banco. Tudo isso deu uma dimensão midiática ainda não experimentada pelas referidas agremiações. Ao mesmo tempo o luxo e a riqueza de detalhes foram sendo incorporados. Artistas do festival de Parintins ganharam notoriedade e foram, inclusive, contratados por grupos carnavalescos do Rio de Janeiro e depois de São Paulo. Hoje o festival de Parintins é o maior evento folclórico do estado do Amazonas e Parintins um dos 65 municípios indutores do Brasil.

A cidade se prepara para o festival durante o ano todo. As agremiações folclóricas de Bois antecipam a definição do tema e o "enredo". Desta forma os diretores de arte podem fazer suas pesquisas e definir o "desenho do boi”. Até mesmo os compositores de toadas definem suas composições que colocadas a disposição da comissão folclórica e diretores dos Bois, geralmente em concursos de toadas, podem vê-las sendo tocadas durante o evento.

O Festival Folclórico de Parintins é um evento composto por uma competição entre quadrilhas geralmente, na semana anterior ao evento principal que hoje se realiza no último fim de semana do mês de junho. Antes eram nos dias 26, 27 e 28 de junho, este último, Dia de São João.

Todavia, a preparação das duas agremiações ganha caráter de festival e de rivalidade já a partir do mês de abril quando são lançados os CDs e DVDs dos dois Bois para o festival. Em anos anteriores esse lançamento era único e se fazia numa grande festa, tanto no curral do boi Garantido como do boi Caprichoso. Nos últimos três anos com a inserção do DVD nos dois grupos, a gravação do DVD e CD é motivo de uma grande festa e rivalidade. Essa rivalidade que estamos falando se refere a uma guerra midiática e de público. Ambas as agremiações divulgam seus eventos e conclamam o público parintinense e manaura a prestigiar. São milhares de pessoas, fãs das agremiações, que são atraídas tanto da cidade e seus arredores, ai incluindo os municípios vizinhos, como de Manaus e seus arredores, também. Difícil definir qual atrai mais público, mas ambas se definem como a melhor e a que levou mais público para o seu evento, e assim acontece com todos os demais eventos realizados na preparação para os três grandes dias do Festival de Parintins. 


\subsection{1 "Festa de Boi" antes do Festival}

Os eventos pré-festival são marcadamente o momento em que a população parintinense realmente participa e revive a tradição da festa de dançar o Boi-bumbá. Esse momento único se caracteriza pela presença do Boi-bumbá no seu curral ou na rua, demonstrando a capacidade do boi e sua rivalidade com o contrário que geralmente realiza o mesmo ritual. Para a população é o momento de comemorar, de dançar, de ir para o curral do boi querido e cantar as doadas já consagradas e as novas. Realmente é o momento daqueles que vivem na cidade e tem sua história ligada aos dois bois se realizarem. Cantam, dançam, tiram fotos, batem palmas, fazem fogueiras, em fim se aproximam do seu Boi do coração, sejam jovens, adultos, idosos, todos querem participar desse momento. É o momento da liberdade pois o acesso é livre e todos podem participar.

"Eu já não posso mais ir pro festival, já tô velha, mas não perco uma alvorada [uma das festas de rua do Garantido]. Só aqui a gente pode chegar perto do Boi”, diz dona Sula, 60 anos, moradora do bairro São Benedito, torcedora do Garantido.

Os preparativos nos currais são grandes para os eventos de rua (ou Boi de Rua), pois é característica da festa de boi sair às ruas para a apresentação. Antes de 1966, quando teve início o Festival em lugar fechado e noites definidas, cada Boi saia às ruas e também para casas onde havia festa e este era convidado:

"Nesta época, o Boi (...) saia às ruas iluminado pela luz de lamparinas para brincar nas casas onde a receptividade era festiva. $\mathrm{O}$ dono da casa, seus familiares e convidados faziam o círculo no terreiro para o boi que, em tons de gaiatice, juntamente com Pai Francisco e Mãe Catirina, arrancavam aplausos dos espectadores que, no toque cadenciado do dois prá lá, dois prá cá, dançavam com a marujada, com os índios e as figuras engraçadas, sob o comando do Amo que entoava toadas simples e desafios ao contrário" (Odinéia Andrade, folclorista parintinense e pesquisadora do Caprichoso, citada em VALENTIN, 2005, p. 100).

Mesmo depois da instituição do Festival, nos primeiros anos, o boi ainda se fazia presente nas ruas, nos dias dos santos, e nas festas para onde era convidado. Na medida em que o Festival foi se configurando como um grande evento e o Boi foi se tornando uma verdadeira “atração' e ganhando importância, as visitas às casas ficaram impossíveis. 
Os ensaios nos currais e os "boi de rua" diferem dos dias do Festival quando todo o mecanismo de controle e de restrições são impostos aos torcedores, principalmente pela limitação do espaço do evento, o Bumbódromo, como pelo preço a ser pago e a presença de muitos turistas, praticamente o do dobro da população local.

O festival folclórico, nos seus três dias de festa, é para ser visto pela televisão, principalmente pelos moradores da cidade, deixando o barulho e as filas para adentrar ao Bumbódromo para os visitantes.

“Da minha casa fico só olhando o foguetório. Tem muita gente, eu fui lá um dia, chega a dá medo. Melhor é olhar pela televisão" (Mário, 58 anos, morador do bairro Itaúna, torcedor do Garantido.

$\mathrm{Na}$ verdade boa parte da população parintinense não participa das noites de apresentação dos Bois, pois a competição com os visitantes é muito grande. A compra de ingresso tem que ser feita na empresa contratada para tal, primeiramente em Parintins, por força de contrato, e depois em Manaus, ficando aberto via internet para compra em todo o Brasil. Geralmente são disponibilizados $15 \%$ dos lugares para Parintins e se esgotam logo. O preço dos ingressos varia de acordo com o tipo, frequentemente associado à posição dentro do Bumbódromo.

Na tabela 3 estão os preços dos ingressos nesses três anos, enquanto na figura 11 está a distribuição das cadeiras e arquibancada.

Tabela 3 - Preços dos pacotes de ingressos para o Festival Folclórico de Parintins (2011-2013)

\begin{tabular}{l|c|c|c}
\hline \multirow{2}{*}{ Tipo } & \multicolumn{3}{c}{ Preço do pacote para os 3 dias (R\$) } \\
\cline { 2 - 4 } & $\mathbf{2 0 1 1}$ & $\mathbf{2 0 1 2}$ & $\mathbf{2 0 1 3}$ \\
\hline Arquibancadas especiais & 540,00 & 590,00 & 708,00 \\
\hline Cadeiras numeradas tipo 1 & 490,00 & 605,00 & 726,00 \\
\hline Cadeiras numeradas tipo 2 & 350,00 & 440,00 & 528,00 \\
\hline Lugares especiais & - & 770,00 & 924,00 \\
\hline
\end{tabular}

Fonte: organizado pelo autor, com base em jornais e panfletos comerciais 
Os preços são para os três dias e são cobrados $10 \%$ sobre o valor como taxa de serviço. O preço de camarotes para 10 pessoas é a partir de $\mathrm{R} \$ 8.400,00$ e ainda existem camarotes especiais para 40 pessoas a partir de $\mathrm{R} \$ 50.000,00$ (preço de 2012).

Figura 11 - Bumbódromo: suas cadeiras e arquibancadas para cada Boi

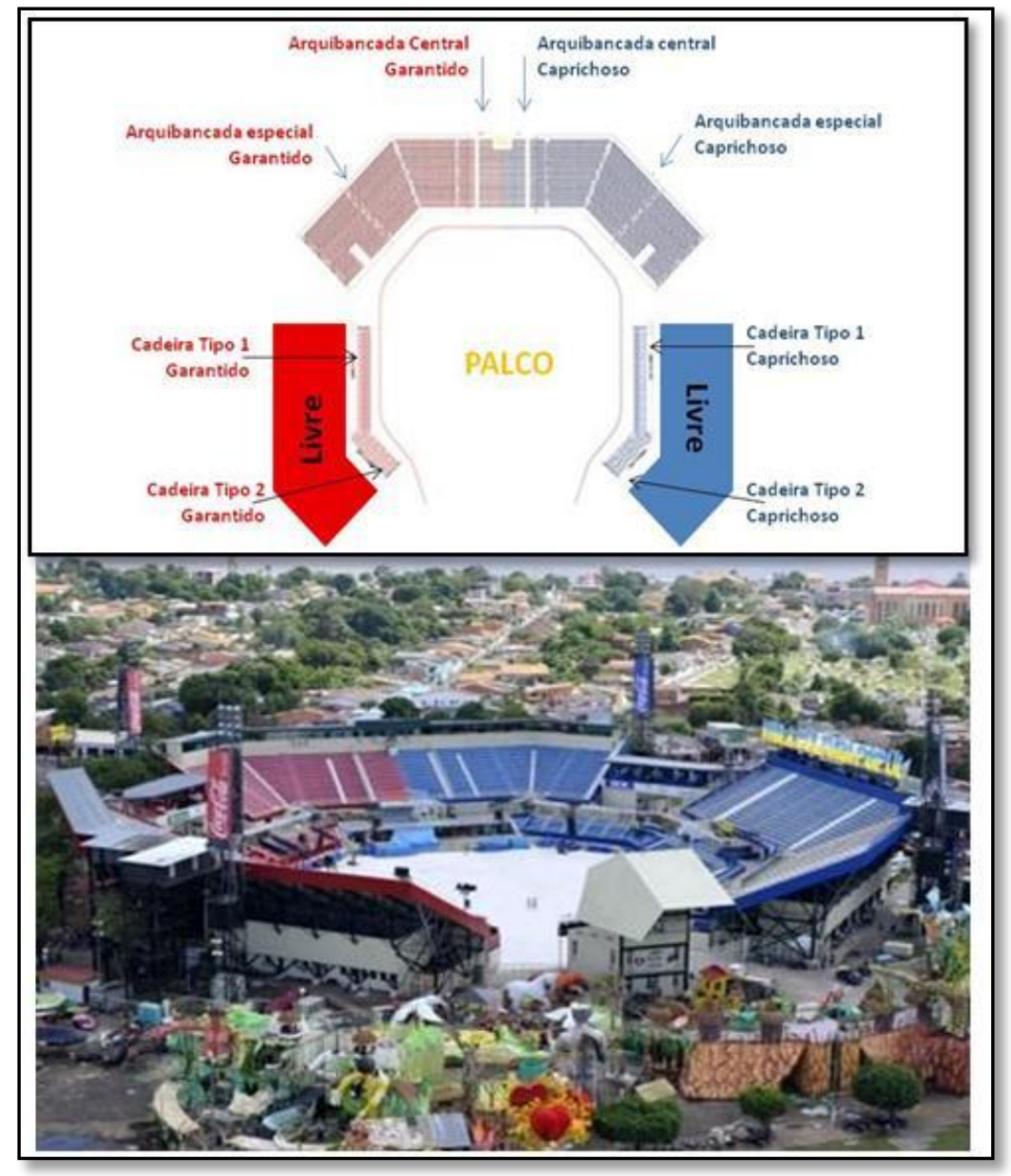

Fonte: organizado pelo autor a partir de jornais e panfletos comerciais

Os turistas frequentemente têm comportamentos distintos. Existem os que compram os lugares no Bumbódromo, geralmente aqueles com maior poder aquisitivo, com acesso diferenciado e exclusivo e os demais que entram na fila de acesso à arquibancada livre (figura 11). Os que preferem essa arquibancada alegam que é a área mais alegre do Bumbódromo, pois é esse setor que concentra a galera, a torcida que faz as acrobacias, os movimentos 
coreografados com auxílio de uma equipe do Boi que fornece o material para a manifestação da torcida: plumas, bandeirolas, balões etc, o que for necessário.

"As coisas aqui não é fácil não, estou desde as 8 horas da manhã. Eu trouxe minha bolsa cheio de coisas pra comer e pra beber. Vou ficar aqui até o Garantido sair... vou participar da coreografia junto com galera... vai ser bom demais", Cintia, 22 anos, na arquibancada livre do Garantido, junho 2012.

"A gente vem pra torcer pelo nosso Boi (Caprichoso), daqui só saio quando acabar...eu vim de Manaus, todo ano eu venho...somos dez (pessoas)...”, Charles, 30 anos, na arquibancada livre do Caprichoso, junho 2012.

É bom lembrar que as torcidas que assistem seu Boi apresentar-se, geralmente o primeiro do dia, saem do Bumbódromo antes da apresentação do Boi contrário, abrindo vaga para a entrada de outros torcedores que já estão na fila e não conseguiram entrar. A estratégia observada é um torcedor ficar esperando na fila inversa do seu boi de preferência para assistilo quando o público sair após a primeira apresentação. A única coisa que estes não podem fazer é adentrar com a cor do Boi contrário na arquibancada do outro, tem que usar uma cor neutra, e também, não pode manifestar-se na arquibancada contrária, pois pelas regras contidas no regulamento do festival, enquanto um Boi se apresenta, inclusive com apoio de sua galera, a outra torcida não pode se manifestar, sob pena de perder pontos. É possível que mais da metade dos que assistiram a primeira apresentação saiam para a entrada de novos espectadores.

Além das 12,2 mil vagas disponíveis no Bumbódromo, são disponibilizados telões que exibem a apresentação na Praça dos Bois, área externa da arena. Da mesma forma, bares e lanchonetes dispostas em todos os lados do Bumbódromo colocam televisores a disposição de seus clientes. São mais de 50 mil pessoas circulando em torno do Bumbódromo durante a apresentação, segundo estimativa dos órgãos envolvidos na segurança do evento.

A Festa de Boi praticada antes da consolidação do Festival Folclórico é o resultado do crescimento da atividade cultural introduzida por imigrantes nordestinos e que ganhou significância ao longo dos anos até tornar-se o maior evento turístico do Amazonas.

A festa foi apropriada pelo capitalismo que tornou o evento um espetáculo para o "mundo ver", todavia o que se percebe é a prática de "dançar o boi", como era feito 
antigamente, guardada as devidas proporções, continua a ser realizada, seja nos ensaios dos bois, realizados nos currais, como nas festas de rua, os "bois de rua" das duas atuais agremiações $^{3}$ (Garantido e Caprichoso).

\subsection{Sobre os turistas no Festival de Parintins}

Nessa pesquisa foi realizada entrevistas com 221 turistas durante o Festival de 2012, constatou-se que a maioria dos visitantes era do próprio estado do Amazonas (62\%), seguido do estado do Pará $(21,7 \%)$, sendo que a cidade de Manaus $(50,2 \%)$ foi a que mais enviou turistas, seguido de Santarém-PA (5,9\%), Oriximiná-PA e Itacoatiara-AM com 4,5\%, em seguida vem Juruti-PA (3,6 \%), todos esses próximos a Parintins (figura 15). Além desses, 13,1\% vieram de outros estados, sendo São Paulo com 3,2\%. Dos outros países foram entrevistados $3,2 \%$, o continente europeu apresenta o maior numero de entrevistados $(2,7 \%)$.

Figura 12 - Turistas em Parintins segundo a origem declarada: junho 2012

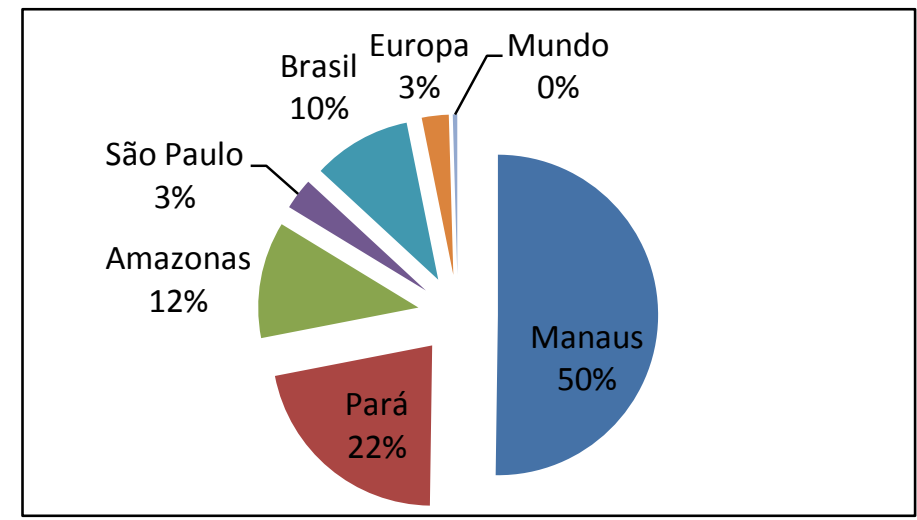

Fonte: Pesquisa de campo, junho/ 2012

\footnotetext{
${ }^{3}$ No Boi Garantido é mais comum chamar as saídas do boi à rua de "passeatas".
} 
A maioria dos turistas entrevistados era do sexo masculino (57\%) e adultos- jovens, com idade entre 26 e 35 anos (38\%), os jovens de 15 a 18 anos são (37\%) dos entrevistados, e viajam por via fluvial, barco regional ou lancha a jato $(76 \%)$.

Figura 13 - Turista em Parintins segundo o meio de transporte

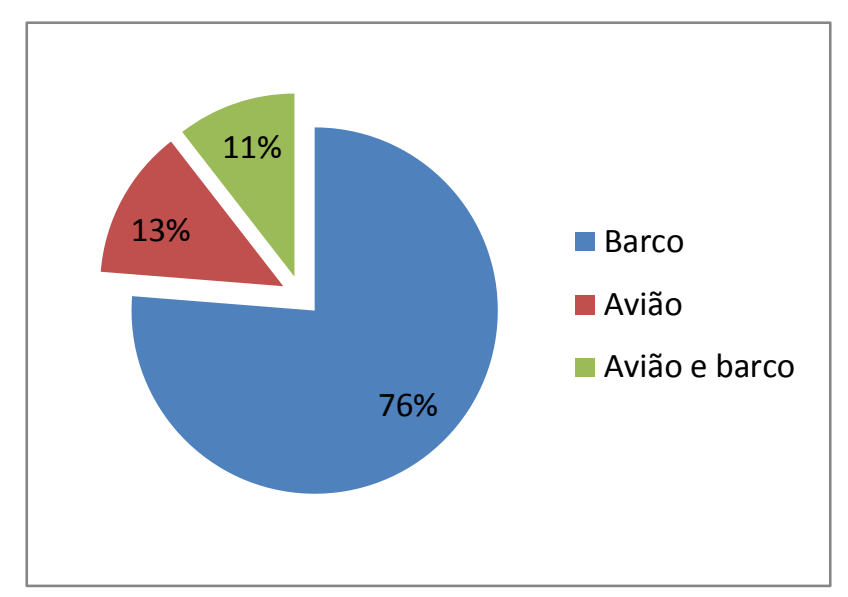

Fonte: Pesquisa de campo, junho/ 2012

Devido as peculiaridade do turismo regional, este ainda é seletivo, comparado muitas vezes como uma aventura, apesar de, ao longo do tempo, estar havendo uma melhoria na infraestrutura oferecida, principalmente no transporte, se considerarmos que hoje há a opção de viajar em lancha motorizada e veloz, com viagem entre Manaus e Parintins que dura de 8 a 10 horas, enquanto a viagem de barco regional é de 18 a 24 horas, tendo que dormir no barco. Isso pode estar provocando uma diminuição da diferença entre homens e mulheres turistas no Festival, por exemplo, a porcentagem dos que viajam de avião, quanto ao sexo é praticamente de $50 \%$. 
Figura 14 - Embarcação regional de transporte de passageiros e cargas

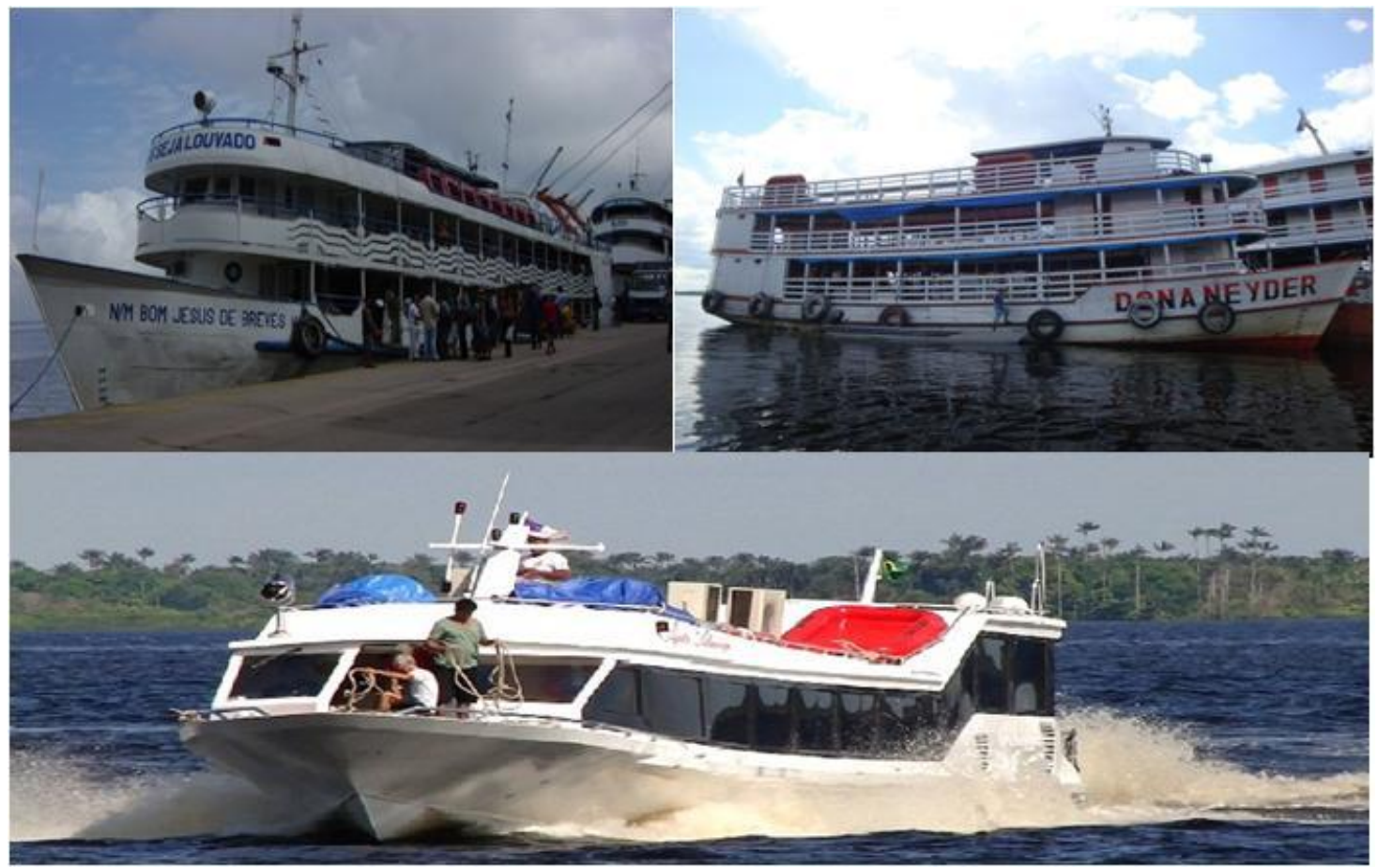

Fonte: Acervo de JDM Azevedo Filho/foto promocional Novo Aliança

O principal meio de transporte de passageiros e carga, no estado ainda é o fluvial. São milhares de barcos regionais construídos de madeira ou em aço com capacidades diversas. As distâncias mais longas são percorridas por grandes embarcações com capacidade para mais de 600 pessoas. Tem crescido na região o uso de embarcações mais velozes e mais confortáveis, especializadas no transporte de passageiros, são denominados como "abato". Parintins tem ligação direta com Manaus por barcos diários que se revezam dia-a-dia. Também é ponto de parada de barcos que seguem com destino ao estado do Pará, principalmente Santarém e Belém, e vice-versa.

A frequência de adultos e idosos no Festival também tem aumentado, são $47 \%$ entre 36 e 55 anos e $7 \%$ de idosos com mais de 55 anos. Os turistas geralmente viajam em grupo ou em família. 
Figura 15 - Percentual de Turistas em Parintins segundo origem declarada: junho 2012

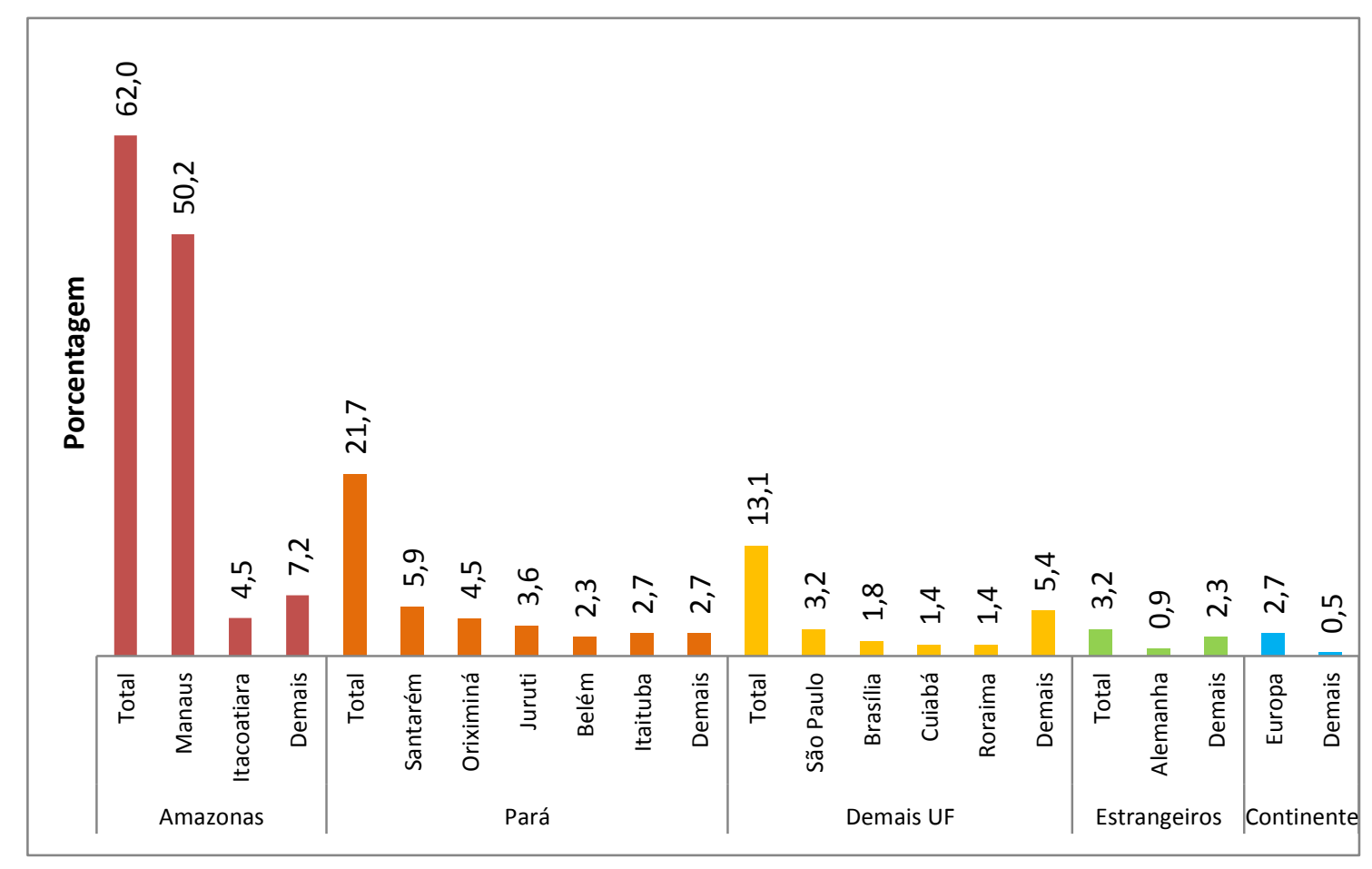

Fonte: Pesquisa de campo, junho/ 2012

Na pesquisa de satisfação realizada através de questionário enviado por e-mail aos turistas contatados durante o Festival de 2012, sendo que foram devolvidos respondidos 35 questionários (16\%), obteve-se o seguinte resultado:

Meio de transporte para a viagem: 73,3\% consideram satisfatório e ótimo e 26,7\% consideraram regular. Como $60 \%$ fizeram sua viagem por meio fluvial é possível considerar a qualidade desse tipo de transporte nessa avaliação.

Hospedagem: foi considerado satisfatório e ótimo (80\%) e 20\% regular. Cabe considerar que a maioria dos entrevistados hospedou-se em casas de amigos e parente e em pousadas o que pode comprometer a resposta, todavia é válida para estabelecer a relação entre demanda e oferta de hospedagem em Parintins durante o Festival.

Alimentação: $46,7 \%$ consideram satisfatória e $20 \%$ ótimo a refeição oferecida na cidade, somente $33,3 \%$ a consideram regular ou insatisfatória. O que representa o esforço dos fornecedores desse item na melhoria da qualidade e quantidade na oferta. 
Preço: os preços praticados nos diversos estabelecimentos da cidade são considerados como regular e insatisfatório pela maioria (60\%), 26,7\% consideraram regular e 13,3\% ótimo. Há uma maior dispersão nesse quesito, havendo opiniões divergindo de satisfatório, regular e insatisfatório. O preço de um produto atinge diferentemente as pessoas, dado a diversas condições como renda, mas principalmente, a sua predisposição em gastar. Não se fez nenhuma comparação entre os preços praticados antes e depois do festival ou mesmo com outras praças, todavia é comum, Brasil a fora, uma variação dos preços dos produtos e serviços na alta temporada.

Figura 16 - Festival de Parintins: Pesquisa de satisfação, junho 2012

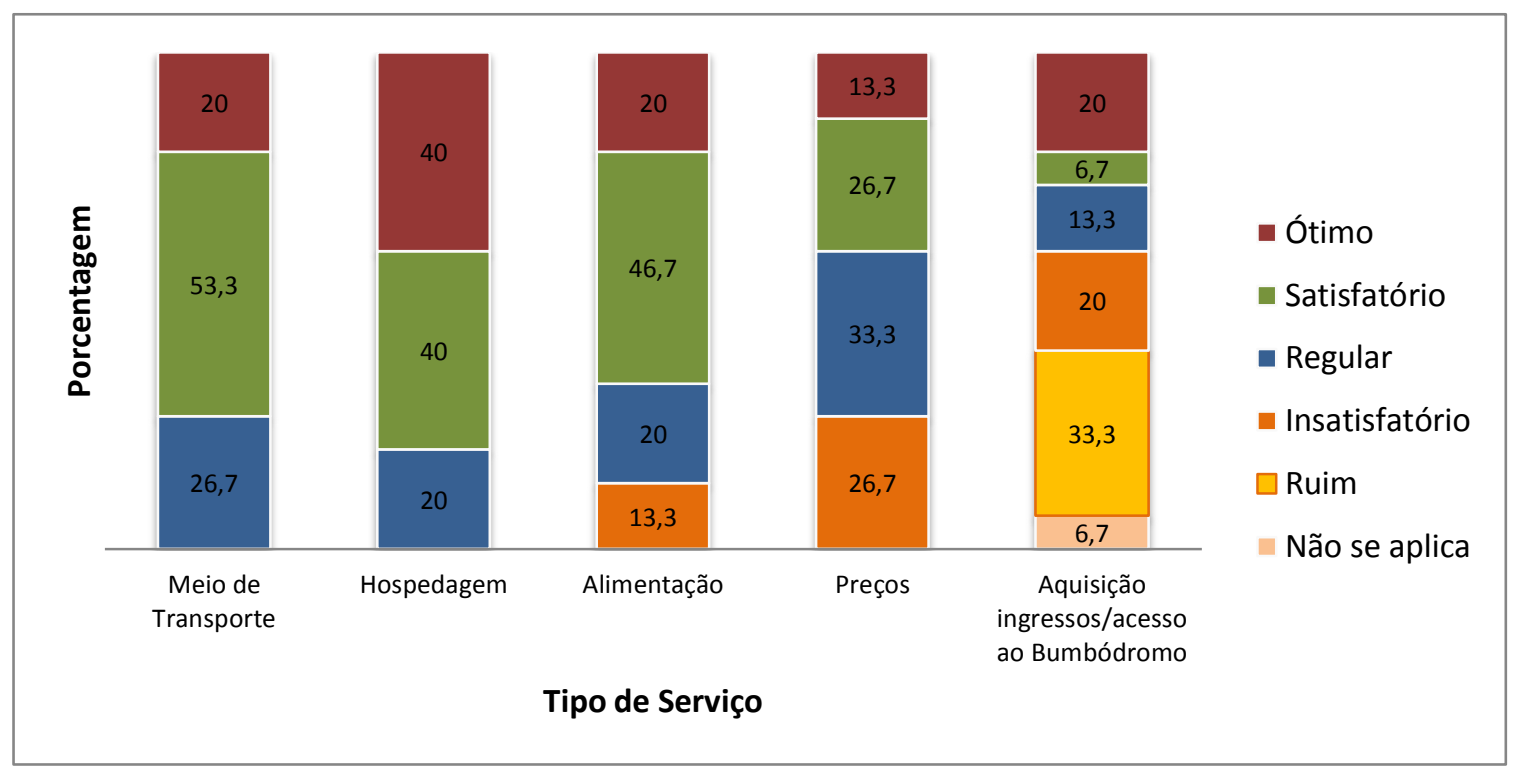

Fonte: Pesquisa de campo, junho/ 2012

Aquisição de ingresso e acesso ao bumbódromo: os ingressos para o evento são adquiridos junto a empresa, contratada para tal, meses antes, de modo que aqueles que não tiveram acesso ao ingresso, vão ter que comprar das mãos de cambistas ou, ainda, dirigindo-se à entrada para as arquibancadas livres, tendo que entrar na fila de acesso desde as primeiras horas da manhã, com entrada permitida a partir das 15 horas. 53,3\% dos entrevistados consideraram insatisfatório e ruim, que se somados aos que consideraram regular $(13,3 \%)$, chega aos $67 \%$, somente $26,7 \%$ consideraram ótimo e satisfatório. O resultado mostra a insatisfação dos turistas quanto a esse item. 
Atividade noturna: esse item remete a diversas atividades relacionadas a atuação de opções noturnas, como boates, bares, casas noturnas. 46,7\% dos entrevistados responderam ótimo, $13,3 \%$ insatisfatório e $20 \%$ regular. Isso mostra que as atividades paralelas ao grande show conseguem atender, em boa parte, os anseios daqueles que procuram opções para aproveitar a noite, principalmente depois da apresentação da noite dos bois.

Atrativos naturais: $60 \%$ consideraram ótimo e satisfatório e $20 \%$ regular. A cidade de Parintins, cravada bem do centro da bacia amazônica, tem áreas naturais em todas as direções e podem ser contempladas, desde que tenham a possibilidade de sair do centro da cidade.

Atrativos culturais: $60 \%$ dos entrevistados consideraram ótimo e satisfatório e 33,3\% regular e insatisfatório. Os atrativos culturais referem-se ao próprio Festival e as diversas manifestações realizadas durante o período, como exposições, danças etc.

Atendimento ao turista: praticamente $60 \%$ consideraram insatisfatório e ruim, enquanto 33,4\% consideraram ótimo e satisfatório. $\mathrm{O}$ atendimento ao turista refere-se a atuação do Centro de Atendimento ao Turista (CAT), agentes públicos ligados aos órgãos do turismo local. Nesse sentido, o atendimento é precário, mesmo com reforço por parte do órgão estadual (Amazonastur), deixa muito a desejar.

Guias ou monitores: existem monitores disponibilizados pela Amazonastur e pela coordenadoria de turismo do município, além de guias turísticos ligados a empresas turísticas sediadas em Parintins e em Manaus, e também, da Associação de Guias de Turismo de Parintins. 33,3\% dos entrevistados consideraram satisfatório esse atendimento, 26,7\% acharam regular e $20 \%$ insatisfatório.

Entre os entrevistados, quando se perguntou quais os lugares que visitou, apontando lugares como Vila Amazônia, Paranapanema, Zé Açu, Valéria, apenas 4 lugares foram apontados por 7 entrevistados, $67 \%$ disseram que não conhecem a região. Isso mostra o quanto ainda tem que ser feito na divulgação e no estabelecimento de roteiros turísticos em direção as várias localidades onde se pode fazer algum tipo de turismo.

Apesar dos entrevistados apontarem algumas dificuldades e problemas com os produtos e serviços oferecidos em Parintins, a totalidade dos entrevistados disseram que retornariam outras vezes à Parintins. 
Figura 17 - Festival de Parintins: Pesquisa de satisfação (Cont.), junho 2012

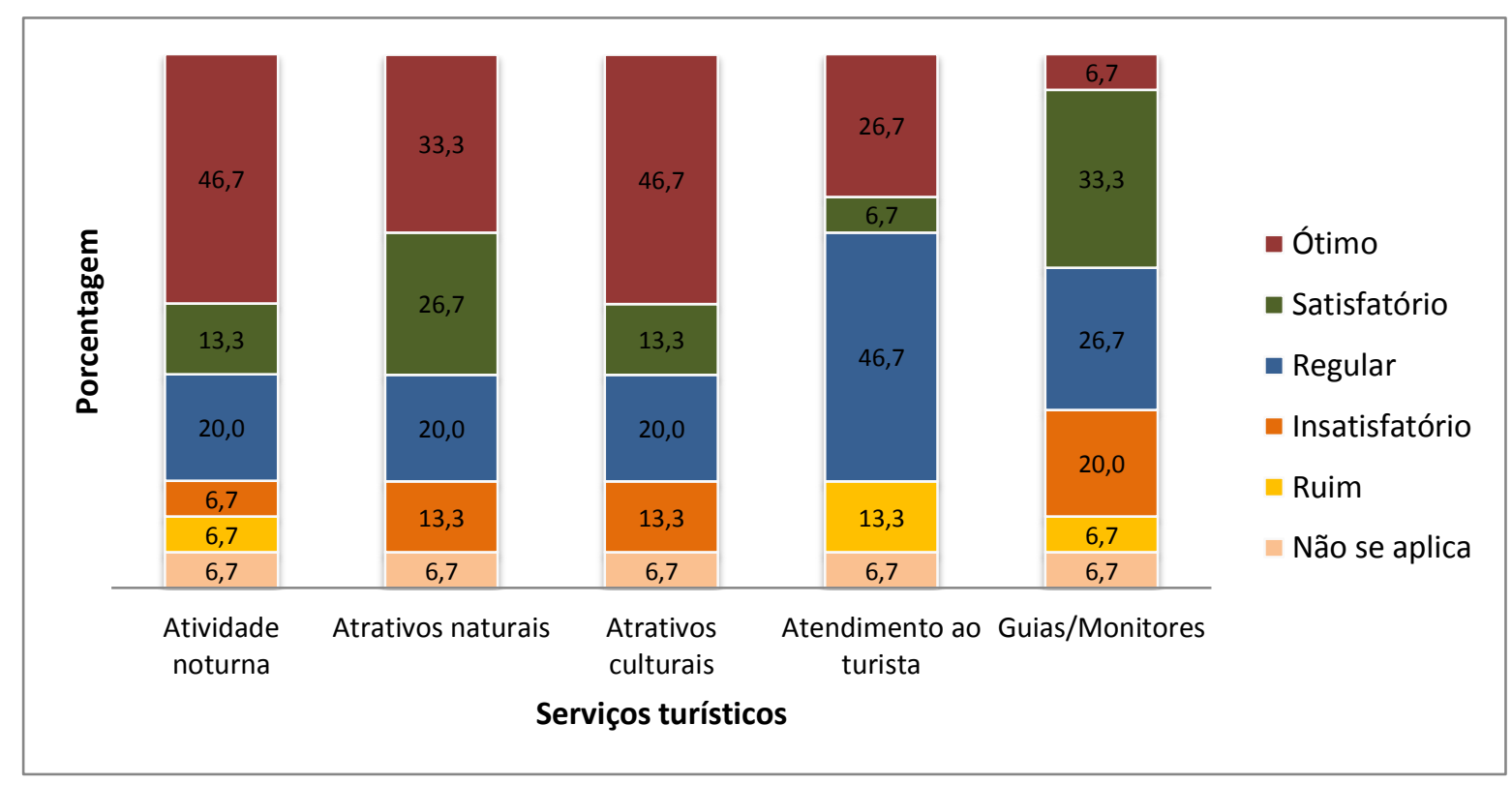

Fonte: Pesquisa de campo, junho/ 2012

Os entrevistados foram convidados a opinar sobre as melhorias que gostaria de encontrar na próxima viagem: as queixas recaem sobre a compra de ingressos para o Festival que, a essa altura, só por atravessadores (cambistas); o acesso à área livre feito por fila e ordem de chegada, não agrada os visitantes, pois ficam muitas horas ao sol e à chuva; a disponibilidade de banheiros públicos e mais bem distribuídos; os preços dos alimentos também foram questionados, além da qualidade, sugerindo-se visita da vigilância sanitária nas cozinhas; as maiores queixas recaem sobre a segurança, controle de trânsito, saneamento básico, o sistema de coleta de lixo, associado a falta de uma campanha de educação ambiental; os preços dos produtos e serviços foram criticados, inclusive de transporte; o tamanho do Bumbódromo também foi lembrado, sugerindo-se sua ampliação.

A maioria das reivindicações apontadas é do cotidiano da população, como saneamento básico, a falta de esgotos provoca mal cheiro em algumas ruas, policiamento e segurança no transito, são problemas enfrentados no dia a dia. Quase não foi citado o sistema de saúde, provavelmente pelo baixo índice de ocorrências, além do que, para o Festival, o sistema é reforçado. 
Outro item solicitava sugestão para melhorar o Festival, sendo apontado: o aumento do numero de voos aéreos e seu barateamento; maior atenção ao turista, com informações, guias etc; um ordenamento no centro e em torno no Bumbódromo quanto a presença de barracas e camelos; e um programa de educação ambiental para evitar poluir a cidade e os rios.

Por fim, foi solicitado comentar sobre a importância do Festival de Parintins: todos apontam o Festival como um divulgador da cultura local e amazonense que deve ser valorizada e mais divulgada.

Os visitantes têm preocupações com o lugar que visitam. Apontar erros e sugerir soluções faz parte desse processo. Ainda não se tem mecanismos de políticas públicas para absorver esses questionamentos no sentido de melhorar a relação do visitante e o visitado. É preciso repensar formas de planejar o turismo que leve em conta os interesses dos verdadeiros atingidos pela ação, as pessoas, tanto os que chegam (turistas) como os que aqui residem.

\subsection{Parintins, Bois-Bumbás e os cruzeiros}

Parintins é um grande atrativo turístico que vai além de seu Festival, os cruzeiros já descobriram esse potencial e tem a cidade sede e Boca da Valéria como um dos pontos de paradas. Todos os anos dezenas de navios transatlânticos navegam pelo rio Amazonas trazendo milhares de turistas de diversas partes do mundo. Esse tipo de turismo, os cruzeiros marítimos, é considerado como "turismo de viagem" e não de destino, pois o produto, ou mesmo o serviços, é disponibilizado para consumo durante o deslocamento e não no destino. As opções em terra acabam sendo um adicional entre as muitas opções do transatlântico (PEREIRA e ROBLES, 2010).

A atividade de turismo em transatlântico é pouco estudada no Brasil. Nos EUA e Europa, estudos apontam um crescimento significativo desse segmento desde os anos 1980. Fala-se em "globalização dos mares" no sentido que os navios e suas empresas ganham conotação internacional e sua filiação não é apenas com os países centrais, mais se fazem com os países periféricos, principalmente aqueles que oferecem possibilidades de contratação de 
mão de obra qualificada e de baixo custo e de impostos. São os denominados "bandeira de conveniência", ou seja, o navio ganha a bandeira onde o país oferece menos custos de impostos e mais possibilidade de lucro (WOOD, 2000).

Nessa fase da globalização do setor de cruzeiros houve uma maior internacionalização das propriedades de navios e uma maior concentração de empresa do setor com uma redução de empresas no jogo (WOOD, 2000).

Nos anos 80 e início dos anos 90, a Cunard adquiriu vários navios noruegueses e o nome Royal Viking, mas em 1996, a Trafalgar House foi adquirida por uma empresa norueguesa, a Kvaerner ASA. Dois anos mais tarde, a Kvaerner vendeu a Cunard à Carnival Corporation baseada nos Estados Unidos, que prontamente fundiu-a com sua linha de cruzeiros de luxo Seabourn. A Carnival, apesar do fato de ter sua sede na Flórida, está registrada como uma empresa panamenha, sua principal concorrente, a Royal Caribbean, também com sede na Flórida, é formalmente uma empresa liberiana. Estimase que a Royal Caribbean economiza aproximadamente US\$ 30 milhões por ano em impostos dos EUA por registar os seus navios na Libéria e na Noruega (WOOD, 2000, tradução livre).

Nesse sentido, reforça-se a necessidade da expansão capitalista do setor de cruzeiros em busca de novas rotas e portos, sem falar no avanço das vendas para níveis médios de renda e segmentos mais jovens. O incremento de valores ambientais nos roteiros turísticos não é novidade no segmento e vem incorporando novos portos em busca desse atrativo. A "Boca da Valéria" se insere neste contexto.

Wood (2000), em seu estudo sobre o Caribe, aponta que tanto a média de idade quanto a renda média dos passageiros tem diminuído entre os viajantes que escolhem os cruzeiros, aumentando o número de passageiros. O Caribe tornou-se um forte atrativo para os turistas de cruzeiros como também para as grandes empresas de navegação do setor, pois encontraram de um lado, as características naturais de sol e praia que atraem os turistas das médias e altas latitudes, com rigoroso inverno, para uma região onde as altas temperaturas acontecem o ano todo. Por outro lado, os países e regiões do Caribe tornaram-se boa opção para negócios num tempo de globalização: mão de obra barata, facilidade de fluxo de capital entre outros aspectos (WOOD, 2000).

No Brasil o segmento tem crescido devido primeiramente a Lei de Modernização dos Portos de 1993, que possibilitou a reinstalação e consolidação do cruzeiro marítimo no país e 
também, a regulamentação da navegação de cabotagem dada a partir de emenda Constitucional de 1995 que permitiu a presença de empresa estrangeiras no transporte de cabotagem. Por conta disso, é crescente a demanda por cruzeiros em um mercado que tem atingido cada vez mais outras camadas da sociedade interessadas em viajar de transatlântico. Além disso, o setor tem investido na diversificação das rotas e opções de lazer, como os cruzeiros temáticos: com cantores, óperas e shows.

\subsection{Cruzeiros pelo Rio Amazonas}

Hoje trafega pelo rio Amazonas mais de 25 roteiros de navios de cruzeiros no período compreendido entre outubro e maio (tabela 4), período do circuito de transatlânticos, justificado pelo período de inverno nos países do hemisfério norte.

Quanto aos turistas em Cruzeiros Marítimos no Amazonas, a Amazonatur, em levantamento realizado em 2012, calcula que houve um crescimento médio anual de $6,71 \%$ no período de 2003 a 2011, dos 154.750 turistas no período. Foram 23 navios de cruzeiros em 2011, com 23.946 passageiros, com uma média de 1.041 passageiros por navio.

Tabela 4 - Navios de Cruzeiros e Passageiros no Amazonas - 2003-2011

\begin{tabular}{|c|c|c|c|c|c|c|c|c|c|c|}
\hline Ano & $\mathbf{2 0 0 3}$ & $\mathbf{2 0 0 4}$ & $\mathbf{2 0 0 5}$ & $\mathbf{2 0 0 6}$ & $\mathbf{2 0 0 7}$ & $\mathbf{2 0 0 8}$ & $\mathbf{2 0 0 9}$ & $\mathbf{2 0 1 0}$ & $\mathbf{2 0 1 1}$ & Total \\
\hline Passageiros & 18.969 & 12.830 & 18.363 & 16.098 & 16.286 & 17.655 & 15.955 & 14.648 & 23.946 & $\mathbf{1 5 4 . 7 5 0}$ \\
\hline Navios & 24 & 19 & 34 & 15 & 23 & 24 & 16 & 19 & 23 & $\mathbf{1 9 7}$ \\
\hline Média & 790 & 675 & 540 & 1.073 & 708 & 736 & 997 & 771 & 1.041 & $\mathbf{7 8 6}$ \\
\hline
\end{tabular}

Fonte: Síntese dos Indicadores de turismo do Amazonas 2003-2011 (Amazonastur, 2012)

3.6.1 Como se dá a preparação para a chegada dos navios de cruzeiros

A excursão em cruzeiros é preparada por agências internacionais sediadas nos EUA e na Europa. São elas que vendem os pacotes de viagem que podem incluir os roteiros de terra ou não. Os roteiros de terra são preparados pelos agentes de viagem locais ou em consórcio com as agencias internacionais que vendem os roteiros aos passageiros ou os incluem no preço total da viagem. 
Necessariamente não são todos que adquirem o roteiro em terra ou que se aventuram em atividades pré-definidas pelas agencias. Os passageiros são avisados dos pontos de parada com antecedência e dos serviços disponíveis em terra. No caso especifico de Parintins e Boca da Valéria, são distintos em sua forma e conteúdo.

Primeiro, o caso de Parintins, por ser uma sede municipal, urbana, compreendendo uma serie de serviços e empresas, o intercâmbio com as agências internacionais é mediado por uma agência ou agente local da empresa que tem o objetivo de organizar a chegada do navio e preparar as atividades de terra que podem incluir citytour, passeios de barco, shows. Tudo pré-definido e cronometrado. Neste contexto é aproveitada a infraestrutura local, como Porto, os serviços públicos, incluído o de segurança.

Conforme a entrevista com os agentes de turismo locais, o receptivo é todo organizados por eles: "A gente participa de congressos em varias as partes do mundo, uma reunião do trade do Caribe, eles nos convidaram para participar. A gente participa da feira em Hamburgo, Miami e agora nós vamos para Curaçao o último foi no Caribe, e lá nos fechamos negócios com as grandes empresas por 2 anos. Nada é fechado por aqui, só nesses encontros". AG, proprietária de agência de viagem em Parintins.

Os artesãos locais também são contatados e repassadas as datas do desembarque. São profissionais organizados em associação e estão constantemente produzindo seus trabalhos para atender as festas e eventos durante o ano todo: carnaval, pastorinhas, festival folclórico, turistas de transatlânticos. Alguns têm loja própria e produzem seus trabalhos em ateliês localizados na própria loja ou em sua residência. Aqueles que não têm loja produzem em sua residência e os comercializam em barracas nos dias festivos ou com a presença de turistas. Geralmente essa atividade é familiar envolvendo um ou mais membros da família. Em momentos de grande demanda é possível contratar terceiros.

A Associação dos Artesãos possui uma estrutura com barracas desmontáveis que possibilita instalarem-se próximo ao porto durante as paradas dos navios. 


\subsubsection{Cruzeiros na Boca da Valéria}

No caso da Boca da Valéria o contato é feito com os representantes da Comunidade local que se dizem representantes da Associação dos Moradores, artesãos, barqueiros e demais agentes ligados ao turismo. Cabe a eles, conclamar a comunidade a preparar o ambiente para o turismo. Como se pode ver não há participação do Estado. O preparo para a chegada dos navios, consiste em fazer a limpeza da área, construir o "porto", que é local feito de madeira onde as lanchas aportam, preparar as barracas onde serão vendidos os artesanatos, e preparação de suas casas que podem ser visitados pelos mesmos. O passeio de canoa tem ganhado importância na oferta de serviço e já é considerado um ponto forte do receptivo.

Sobre a produção do artesanato, este é um ponto a ser descrito. Todos os artesãos entrevistados foram unanimes em afirmar que não são artesãos exclusivamente. São primeiramente pescadores ou agricultores, ou ambos. Durante os demais períodos exercem as diversas atividades conforme a sazonalidade ou a disposição da própria natureza. O período da enchente dos rios da bacia amazônica, na região, reduz a oferta de peixe, o que desloca aqueles que se dedicam a pescaria para as atividades em terra firme, como caça, coleta e manejo do gado. O manejo do gado é alternado, sendo que durante a cheia o gado é deslocado para a terra firma e quando as águas baixam e a terra de várzea reaparece o gado retorna. Nesse caso, a mão de obra é assalariada, seja temporária nas fases de deslocamento, seja permanente, no manejo diário do gado.

A agricultura local se baseia tradicionalmente no cultivo da mandioca e na produção de farinha. Outros cultivos são a banana, abacaxi, milho e melancia que obedecem ao calendário sazonal do regime dos rios.

Desse modo, o artesão-agricultor-pescador tem se adaptado as diversas atividades conforme a demanda. Para o artesão, o mês de setembro marca o período de busca, coleta e compra do material para a confecção do artesanato. Havendo disponibilidade esse período pode ser dilatado para o mês de agosto, quando, por exemplo, houve sobra da matéria prima no ano anterior. Todavia, no mês de setembro os artesãos antecipam a produção do que será vendido durante as paradas dos navios em sua região. A partir daí o trabalho é continuo, baseada na demanda do turismo. As primeiras vendas estimulam as seguintes. 


\subsection{Turismo em Parintins para além do Festival Folclórico}

Como já foi dito, a Organização Mundial de Turismo - OMT considera o turismo como uma modalidade de deslocamento espacial que envolve a utilização de algum meio de transporte e ao menos um pernoite no destino; esse deslocamento pode ser motivado pelas mais diversas razões como: lazer, negócio, congressos, tratamentos de saúde e outros motivos, desde que não correspondam a formas de remuneração direta. Assim são estabelecidos a segmentação turística: religioso, de eventos, de aventura, de negócios, de saúde, ecológico etc. Lembrando que essa definição da OMT sugere que viagem e turismo sejam a mesma coisa. A título de contabilização dos números, são incluídas todas as pessoas que de deslocam nesses moldes, podendo utilizar-se da infraestrutura local, sem, contudo se utilizar dos equipamentos turísticos, eis ai o grande problema.

Se por um lado superestima-se o fluxo de turistas, por outro há um esquecimento, quando se refere aos deslocamentos de curta distância e que não utilizam meios convencionais e com controle institucional. No caso da Amazônia, é grande o fluxo de pessoas entre suas médias e pequenas cidades. Os eventos realizados em várias cidades, por exemplo, não entram nas estatísticas oficiais como turismo. Há dificuldade de se estabelecer o número exato de turistas que veem ao Festival Folclórico de Parintins, posto que a maioria, como já foi dito, viaja de barco regional e esses não entram nas estatísticas.

\subsubsection{O turismo além do Festival dos Bois}

O turismo em Parintins depende hoje basicamente do que acontece no Festival Folclórico. São recursos federais, estaduais e privados que movimentam a economia da cidade e da capital, haja vista que boa parte dos insumos utilizados nos galpões dos Bois é comprada em Manaus e em São Paulo. A cidade se refaz a cada festival e, por isso, essa dinâmica impõe aos que querem compreender o turismo uma constante reflexão e redefinição dos conceitos e métodos utilizados para sua análise.

Mas, também, como uma atividade humana, como diz Knafou (2001), está sujeita aos conflitos resultantes dos interesses antagônicos de uma sociedade de classe em um mundo 
globalizado. Assim, o que se projeta para Parintins e seu Festival nem sempre tem suas raízes neste terreno, quiçá, nem mesmo no Brasil. No entanto, é possível se pensar para além do Festival e caminhar para um turismo com maior envolvimento das comunidades urbanas ou rurais, de modo que após o Festival não fique somente o grande montueiro de lixo e de resíduos das grandes estruturas de metal com que são produzidas as alegorias como um passivo a ser absorvidos por todos. Já foi dito que a cultura do Boi-Bumbá tem a participação da população, não só nos três dias da grande festa, mas se dá ao longo do ano e no período de ensaios e festas de rua. Agora cabe pensar o turismo como uma atividade econômica que pode ajudar a melhorar as condições de vida e de renda da maioria da população.

O calendário de eventos de Parintins dá uma ideia das possibilidades criativa das comunidades que podem ser beneficiadas com o turismo. O montante investido no evento superou os $\mathrm{R} \$ 3.000 .000,00$ em 2011, sendo que mais $\mathrm{R} \$ 200.000,00$ estariam destinados às demais atividades de eventos que acontecem em todo o município durante o ano (SICTUR, 2011)

Quadro 2 - Calendário de Eventos da SICTUR e orçamento em 2010, Parintins

\begin{tabular}{|c|c|c|c|c|c|}
\hline EVENTO & REALIZAÇÃO & DATA & LOCAL & DESCRIÇÃO & VALOR \\
\hline $\begin{array}{l}\text { Festival de } \\
\text { Pastorinhas }\end{array}$ & $\begin{array}{l}\text { Prefeitura } \\
\text { Municipal }\end{array}$ & Janeiro & Praça dos Bois & $\begin{array}{l}\text { Apresentação dos } \\
\text { grupos de } \\
\text { Pastorinhas - } \\
\text { concurso e } \\
\text { premiação }\end{array}$ & - \\
\hline Carnailha & $\begin{array}{l}\text { Governo do } \\
\text { Estado } \\
\text { Prefeitura de } \\
\text { Parintins } \\
\text { Patrocinadores }\end{array}$ & $\begin{array}{l}\text { Fevereiro/ } \\
\text { Março }\end{array}$ & Av. Paraíba & $\begin{array}{c}\text { Desfile de Blocos } \\
\text { Carnavalescos }\end{array}$ & $\mathrm{R} \$ 800.000,00$ \\
\hline $\begin{array}{l}\text { Paixão de } \\
\text { Cristo }\end{array}$ & $\begin{array}{c}\text { Governo do } \\
\text { Estado } \\
\text { Prefeitura } \\
\text { Municipal } \\
\text { Patrocinadores }\end{array}$ & $\begin{array}{c}\text { Abril/Semana } \\
\text { Santa }\end{array}$ & $\begin{array}{c}\text { Centro Cultural e } \\
\text { Desportivo } \\
\text { Amazonino } \\
\text { Mendes } \\
\text { (Bumbódromo) }\end{array}$ & $\begin{array}{c}\text { Encenação de } \\
\text { atores e figurantes } \\
\text { Coral de } 80 \text { vozes } \\
\text { Trilha Sonora }\end{array}$ & $\mathrm{R} \$ 150.000,00$ \\
\hline $\begin{array}{l}\text { EXPOPIN } \\
\text { Exposição } \\
\text { Feira } \\
\text { Agropecuária }\end{array}$ & $\begin{array}{c}\text { Governo do } \\
\text { Estado } \\
\text { Prefeitura } \\
\text { Municipal } \\
\text { Associação de } \\
\text { Produtores } \\
\text { Patrocinadores }\end{array}$ & Maio/Junho & $\begin{array}{c}\text { Parque de } \\
\text { Exposições Luiz } \\
\text { Lourenço de } \\
\text { Souza }\end{array}$ & $\begin{array}{l}\text { Exposição, } \\
\text { comercialização, } \\
\text { extensão rural, } \\
\text { rodeios, show }\end{array}$ & - \\
\hline $\begin{array}{c}\text { Feira de } \\
\text { artesanato }\end{array}$ & $\begin{array}{l}\text { Governo do Estado } \\
\text { Prefeitura } \\
\text { Associação dos } \\
\text { artesãos }\end{array}$ & $\begin{array}{c}\text { Junho - durante } \\
\text { o Festival } \\
\text { Folclórico }\end{array}$ & Praça dos Bois & $\begin{array}{c}\text { Exposição e venda } \\
\text { de artesanatos }\end{array}$ & $\mathrm{R} \$ 10.000,00$ \\
\hline
\end{tabular}


Continuação

\begin{tabular}{|c|c|c|c|c|c|}
\hline $\begin{array}{c}\text { Festival de } \\
\text { Quadrilhas e } \\
\text { Danças }\end{array}$ & $\begin{array}{c}\text { Governo Federal } \\
\text { Governo do Estado } \\
\text { Prefeitura } \\
\text { Municipal } \\
\text { Patrocinadores }\end{array}$ & $\begin{array}{c}\text { Uma semana } \\
\text { antes do } \\
\text { Festival } \\
\text { Folclórico, } \\
\text { começando na } \\
\text { Quarta-feira e } \\
\text { terminando no } \\
\text { Sábado }\end{array}$ & Praça dos Bois & $\begin{array}{c}\text { Apresentação de } \\
\text { Quadrilhas }\end{array}$ & $\mathrm{R} \$ 60.000,00$ \\
\hline $\begin{array}{l}\text { Festival dos } \\
\text { Bois Mirins }\end{array}$ & $\begin{array}{c}\text { Governo Federal } \\
\text { Governo do Estado } \\
\text { Prefeitura } \\
\text { Municipal } \\
\text { Patrocinadores } \\
\end{array}$ & $\begin{array}{l}\text { Uma semana } \\
\text { antes do } \\
\text { Festival } \\
\text { Folclórico no } \\
\text { Domingo } \\
\end{array}$ & Praça dos Bois & $\begin{array}{c}\text { Apresentação dos } \\
\text { Mirins }\end{array}$ & $\mathrm{R} \$ 40.000,00$ \\
\hline $\begin{array}{c}\text { Festival } \\
\text { Folclórico }\end{array}$ & $\begin{array}{c}\text { Governo Federal } \\
\text { Governo do Estado } \\
\text { Prefeitura } \\
\text { Municipal } \\
\text { Patrocinadores }\end{array}$ & $\begin{array}{l}\text { No ultimo final } \\
\text { de semana do } \\
\text { mês de Junho }\end{array}$ & $\begin{array}{c}\text { Centro Cultural e } \\
\text { Desportivo } \\
\text { Amazonino } \\
\text { Mendes }\end{array}$ & $\begin{array}{c}\text { Disputa das } \\
\text { Agremiações } \\
\text { Folclóricas Bois- } \\
\text { bumbás Garantido } \\
\text { e Caprichoso }\end{array}$ & $\mathrm{R} \$ 1.500 .000,00$ \\
\hline $\begin{array}{l}\text { Festival do } \\
\text { Peixe Liso }\end{array}$ & $\begin{array}{l}\text { Prefeitura de } \\
\text { Parintins } \\
\text { Patrocinadores }\end{array}$ & & $\begin{array}{c}\text { Mocambo } \\
\text { Rio Amazonas }\end{array}$ & $\begin{array}{l}\text { Competição de } \\
\text { Pesca } \\
\text { Concurso de } \\
\text { Rainha }\end{array}$ & - \\
\hline $\begin{array}{c}\text { Festival } \\
\text { folclórico do } \\
\text { Mocambo }\end{array}$ & $\begin{array}{l}\text { Prefeitura de } \\
\text { Parintins } \\
\text { Patrocinadores }\end{array}$ & Julho & $\begin{array}{c}\text { Mocambo } \\
\text { Mocambódromo }\end{array}$ & $\begin{array}{c}\text { Apresentação de } \\
\text { quadrilhas, } \\
\text { pássaros e Boi- } \\
\text { bumbá }\end{array}$ & - \\
\hline $\begin{array}{c}\text { Festa de Nossa } \\
\text { Senhora do } \\
\text { Carmo }\end{array}$ & $\begin{array}{c}\text { Governo do Estado } \\
\text { Prefeitura } \\
\text { Municipal } \\
\text { Patrocinadores } \\
\text { Diocese de } \\
\text { Parintins }\end{array}$ & Julho & Praça da Catedral & $\begin{array}{c}\text { Através do arraial } \\
\text { com atrações } \\
\text { Shows de calouros } \\
\text { e bandas } \\
\text { Desfile de bonecas } \\
\text { vivas }\end{array}$ & $\mathrm{R} \$ 40.000,00$ \\
\hline $\begin{array}{l}\text { Festival de } \\
\text { Verão }\end{array}$ & $\begin{array}{l}\text { Prefeitura } \\
\text { Municipal }\end{array}$ & Setembro & $\begin{array}{c}\text { Praia do Itaracuera } \\
\text { no Rio Uaicurapá }\end{array}$ & $\begin{array}{c}\text { Shows de bandas } \\
\text { musicais } \\
\text { Escolha da Rainha }\end{array}$ & $\mathrm{R} \$ 50.000,00$ \\
\hline $\begin{array}{c}\text { Festival de } \\
\text { Verão do } \\
\text { Caburi } \\
\end{array}$ & $\begin{array}{l}\text { Prefeitura } \\
\text { Municipal }\end{array}$ & Setembro & Praia do Caburi & $\begin{array}{c}\text { Shows de bandas } \\
\text { musicais } \\
\text { Escolha da Rainha }\end{array}$ & - \\
\hline $\begin{array}{l}\text { Festival de } \\
\text { Toadas }\end{array}$ & $\begin{array}{r}\text { Prefeitura } \\
\text { Municipal } \\
\text { Patrocinadores }\end{array}$ & $\begin{array}{c}\text { Outubro } \\
\text { (Aniversário da } \\
\text { cidade - 15) }\end{array}$ & $\begin{array}{l}\text { Praça Digital } \\
\text { "Cristo Redentor" }\end{array}$ & $\begin{array}{l}\text { Apresentação de } \\
\text { Toadas de Boi- } \\
\text { Bumbá - concurso } \\
\text { e premiação }\end{array}$ & $\mathrm{R} \$ 150.000,00$ \\
\hline $\begin{array}{c}\text { Reveillón na } \\
\text { Orla }\end{array}$ & $\begin{array}{l}\text { Prefeitura } \\
\text { Municipal }\end{array}$ & $\begin{array}{c}\text { Dezembro } \\
31\end{array}$ & Orla da Cidade & $\begin{array}{l}\text { Fogos de artifícios } \\
\text { Três palcos } \\
\text { alternativos } \\
\text { Shows pirotécnicos }\end{array}$ & $\mathrm{R} \$ 200.000,00$ \\
\hline
\end{tabular}

Fonte: relatório de atividade da Secretaria de Indústria, Comércio e Turismo, 2011 


\section{CAPITULO IV}

\section{A CARTOGRAFIA DO MEIO AMBIENTE E DO TURISMO EM PARINTINS}

A Cartografia é uma ciência muito importante na interpretação do espaço. Como tal, está sujeita a criteriosa metodologia para representar a realidade. A realidade ambiental e o fenômeno turístico são dois pontos distintos da realidade que tem em comum a convergência para a análise da paisagem, pois ambos implicam na compreensão de suas dinâmicas. $\mathrm{O}$ método cartográfico mais adequado nesse sentido é a cartografia de síntese, pois possibilita o agrupamento dos atributos espaciais e permite a interpretação da realidade vista na paisagem. O município de Parintins tem como base do turismo o seu Festival Folclórico realizado em junho, mas é preciso ir além do Festival e trazer a tona as diversas realidade e possibilidades turísticas, o potencial turístico baseado no conjunto das suas riquezas naturais e culturais, associadas às próprias condições de vida da população local. É nesse sentido que se procurará construir essa possibilidade a partir de um mapa ambiental e turístico para Parintins, apoiado nos ensinamentos de Martinelli e outros autores consagrados.

\subsection{A Cartografia e seu uso no turismo e no meio ambiente}

A Cartografia vem sendo utilizada há muito tempo como instrumento para a compreensão e apreensão do espaço vivenciado pelas sociedades. A construção de mapas para demonstrar a área de domínio e de poder vem sendo feita desde épocas remotas, perpassando o período das Grandes Navegações e a formação dos Estados até hoje, quando, mais do que nunca, as grandes empresas e corporações capitalistas os utilizam para os mais variados fins.

A Cartografia é concebida como uma ciência que unindo conhecimentos artísticos, científicos e técnicos produz mapas. E o mapa nada mais é que a representação gráfica do espaço terrestre, ou seja, o desenho do Globo terrestre (esférico) num plano (mapa). Sendo, portanto, necessários para que isso aconteça, o conhecimento científico, artístico aliados à técnica apropriada. 
A cartografia, enquanto arte, não se reduz a um objeto de decoração, apenas estético. Muito mais que isso, a cartografia como arte se trata da sensibilidade em escolher o formato, a cor do desenho, os dados e as informações geográficas para definição dos símbolos, letras etc. Ao mesmo tempo, ao nível da ciência, deve se voltar ao ato de pensar sua produção final e para tanto se utiliza dos conhecimentos pré-existentes, da matemática, astronomia, semiologia gráfica, sem descartar a análise crítica do que está produzindo, seu destino e objetivo.

Os gregos foram os primeiros a se preocupar com o uso adequado dos mapas, principalmente porque dependiam dos mesmos para suas incursões marítimas e militares.

Erastóstenes de Alexandria (275-194 a.C.), filósofo, matemático e astrônomo, foi um dos primeiros a calcular a circunferência da Terra, obtendo uma precisão significativa, considerando-se os recursos da época. A partir dessa experiência, Hiparco de Niceia (190-125 a.C.) fez a divisão da circunferência da Terra em $360^{\circ}$, além de calcular paralelos e meridianos equidistantes sobre esse globo (JOLY, 2008).

O mais conhecido desenho do globo terrestre, do período, foi o de Ptolomeu (85-165 D.C.), baseado nos conhecimentos de seus predecessores e aprofundando os estudos sobre a esfericidade da Terra, colocando-a no centro do Universo. O seu Atlas está contido na sua obra Almagesto (A Grande Síntese Matemática).

Durante a Idade Média, a Cartografia, assim como os demais conhecimentos já adquiridos pela humanidade, é adaptada para atender aos interesses da Igreja Católica, transformando-se em uma representação simbólica de cunho religioso. Segundo Joly (2008), nesse período foram criados os mapas T.O, "T dentro do O", que mostravam a terra circular, dividida em três partes e tendo a cidade de Jerusalém no seu centro.

A partir do século XII, com o incremento das rotas mercantis e o comércio marítimo foram introduzidos novos aparelhos que facilitavam a navegação como a bússola e o astrolábio, possibilitando a retomada da construção de mapas mais precisos destinados para estes fins. 
Já no século XV, a difusão dos conhecimentos de navegação pela Escola de Sagres ${ }^{4}$, em Portugal, possibilitou a melhoria dos sistemas de navegação e de construção de embarcações, que levaram posteriormente os países ibéricos a alcançarem rotas mais longas e perigosas, culminando com a Era dos Descobrimentos.

Conforme Martinelli (2003c) os mapas, desde seus primórdios, tiveram sempre a finalidade direcionada a sua praticidade, ligada à manutenção de um poder ou sua dominação. "Sempre registraram o que mais interessava a uma minoria, fato este que acabou estimulando o incessante aperfeiçoamento deles” (p. 8). Representam um saber socialmente construído no tempo e no espaço, tem um conteúdo histórico, marcado por intencionalidades. Conforme já foi afirmado por diversos autores (LACOSTE, 1997; MARTINELLI, 2006; JOLY, 2008), a produção de um mapa "não é neutra", e sim ligada à realidade social de seu tempo.

De documento secreto, nos século XV e XVI, os mapas são utilizados hoje por uma gama diversa de usuários, com objetivos distintos. Desde um aluno do ensino básico para suas aulas de geografia, aos grandes estados para estabelecer metas de controle e planejamento do seu território. O mapa se tornou objeto de uso comum num mundo globalizado, onde a difusão de informações e conhecimento se espalha de forma mais ampla com a ajuda das novas tecnologias, aqui se referindo principalmente ao uso de computadores e à internet. Em graus diferentes de utilização, é claro, considerando o nível de renda e de desenvolvimento científico e tecnológico de cada lugar e de seus habitantes.

A Revolução Industrial e o crescimento das relações capitalistas entre os Impérios e suas Colônias marcam o crescente interesse pelos mapas e com isso a necessidade de seu

\footnotetext{
${ }^{4}$ É possível que a Escola de Sagres nunca tenha existido de fato, chegando alguns a considerem como uma linha de pensamento difundido por diversos centros ou escolas de navegação da época. Todavia, " $A$ existência ou não da Escola de Sagres já foi amplamente debatida no panorama historiográfico português. Porém, desde o princípio do século XX que a ideia de uma escola náutica fundada pelo Infante D. Henrique, onde se agrupariam os mais variados sábios, de várias partes da Europa, com objectivo de obter uma vasta informação sobre determinadas áreas científicas como a geografia, a astronomia ou a cartografia, se encontra ultrapassada. Esta ideia é sobretudo uma lenda que carece de provas evidentes, devida principalmente a escritores e historiadores ingleses que procuraram promover a figura e a acção do Infante de Sagres.(...) Para a historiografia actual, (...), a Escola de Sagres, mais do que uma instituição académica, transformou-se sobretudo num símbolo, símbolo do infante D. Henrique e de todas as actividades relacionadas com as navegações portuguesas do seu tempo. Símbolo da progressão das técnicas de navegação adquiridas empiricamente pelos navegadores que enfrentaram o Atlântico no século $X V$, e que criaram as bases da navegação astronómica, tal como veio a ser praticada nos séculos subsequentes - no que é aliás uma das consequências mais importantes dos Descobrimentos" (Centro Virtual Camões, Instituto da Cooperação e da Língua, Ministério dos Negócios Estrangeiros / Portugal, em <http://cvc.institutocamoes.pt/navegaport/g19.html>)
} 
aperfeiçoamento. Eram necessários mapas cada vez mais precisos e que acompanhassem um mundo em expansão. É nesse sentido que Martinelli acentua que:

A busca crescente de mapas para registrar o mundo inteiro, bem como a procura de novos tipos de representações para questões específicas forçaram a entrada da cartografia na manufatura, passo decisivo para a integração no processo capitalista de produção. Os mapas confirmaram-se como armas do imperialismo, promovendo a política colonial (MARTINELLI, 2003c, p. 9).

Para atender a demanda dos interesses imperiais e capitalistas, a Cartografia deixa de produzir mapas especificamente topográficos para produzir mapas mais específicos e detalhados. Nesse sentido, a Cartografia Temática surge como um aperfeiçoamento da Cartografia Topográfica destinada a mapear os recursos naturais e a mão de obra do mundo conhecido, dentro da perspectiva da divisão internacional do trabalho.

É Martinelli (2003) quem enfatiza que essa nova situação de demanda por mapas marca a passagem da Cartografia Topográfica, caracterizada por representar "propriedades apenas vistas", para uma Cartografia Temática que salienta propriedades "conhecidas dos objetos”. Segundo Joly (2008, p. 73) ao longo dos séculos XVIII e XIX foram feitos os mais variados mapas temáticos:

(...) mapas da declinação magnética para os navegantes, mapas de rotas e posições militares, mapas das florestas e mapas das águas, mapas das reservas de caças, mapas geológicos, administrativos, políticos, demográficos, agrícolas, industriais etc.

\subsection{A Cartografia Temática}

Um dos maiores difusores das técnicas da Cartografia Temática na Geografia é o professor Marcello Martinelli, da USP. Muitos de seus trabalhos procuram propiciar ao 
educando a possibilidade de apreender Cartografia Temática de forma crítica. Sua base metodológica se propõe a fazer o interessado compreender os mapas a partir de um raciocínio lógico da informação nele contida. Nesse sentido, salienta a importância de se conhecer a linguagem da comunicação visual, valorizando assim todo o conteúdo de um mapa: o título, a legenda, a escala geográfica e de análise. Para isso, valoriza o caráter monossêmico (um só significado) da produção gráfica: aspectos físicos e sociais do espaço geográfico ou mesmo a relações que se travam da natureza com a sociedade (representada na sua cultura e nas relações sociais).

O professor Martinelli (2003) destaca a fase atual do desenvolvimento da sociedade mundial e o uso da Cartografia Temática e sua disseminação:

Atualmente, a Cartografia como um todo entra na era da informática. Com o auxílio de satélites e computadores, a Cartografia Temática torna-se um verdadeiro Sistema de Informações Geográficas, visando à coleta, armazenamento, recuperação, análise e apresentação de informações sobre os lugares, ao longo do tempo, além de proporcionar simulações de eventos e situações complexas da realidade, tendo em vista a tomada de decisões deliberadas (2003c, p.10).

Assim, a Cartografia torna-se mais complexa, o uso de tecnologias para a produção de mapas não dispensa a necessidade de conhecimento e aprofundamento da lógica de sua produção, uma linguagem que se utilizada de dados, variáveis e atributos para, ao final, apresentar informações que facilitam a compreensão do espaço geográfico. Martinelli, apoiado em autores como Taylor (1991) lembra que quando a produção de mapas temáticos “não basta que os mapas respondam apenas à pergunta “Onde?”. Hoje eles precisam responder também a outras questões como: 'Por quê?', 'Quando?', 'Por quem?', 'Para que finalidade?' e 'Para quem?'” (MARTINELLI, 2003b, p. 16).

Dessa forma, a Cartografia Temática não pode se deter apenas na produção do mapa em si, mas torna-se imperiosa a especificação do evento no tempo e no espaço, sabendo-se que a produção de um mapa não é aleatória, ela tem um objetivo, ou seja, implica uma visão de mundo, política, econômica e social. 
Segundo Martinelli (1999) desde o fim do século XVI começam a aparecer mapas com temas mais específicos, no entanto, a consolidação desse ramo da ciência só acontecerá no fim do século XVIII,

(...) com a sistematização dos vários ramos de estudos consolidados a partir de uma divisão do trabalho científico. Passamos a assistir a um paulatino acréscimo de tematismos à cartografia topográfica eminentemente analógica tomada como base. Essa nova renovação vai se desenvolvendo de forma a romper os liames com o mundo visível, buscando a exploração da variação perceptiva em terceira dimensão visual dissociada do espaço bidimensional intrínseco ao mapa como figura do terreno (MARTINELLI, 1999, p. 227).

Esse período marca a sistematização das várias ciências, ou da Ciência em vários ramos, inclusive a Geografia. A cartografia sempre esteve associada diretamente ao conhecimento geográfico e à geografia como ciência. Todavia, os primeiros mapas temáticos foram de Geologia, dada a importância que essa ciência recebeu como instrumento de reconhecimento das riquezas minerais em várias partes do mundo globalizado.

Lacoste (1988) lembra que foi exatamente a partir do século XIX que essa "tarefa essencial" da geografia, que é representar a Terra em mapas, será dela separada com o nome de Cartografia. Aliás, esse termo substituiu o de cosmografia antes empregado (OLIVEIRA, 1987). A produção de cartas cada vez mais especializada e específica parece ganhar importância ainda maior para os grandes Estados. Segundo Lacoste:

É nessa época, com efeito que, em Estados cada vez mais numerosos, e por razões econômicas e militares, desenvolve-se maciçamente a produção de cartas precisas, em grande escala, o que exige um grande número de especialistas. É também nessa época que os pesquisadores das diversas ciências naturais e sociais começam a estabelecer cartas especializadas, geológicas, botânicas, climáticas, demográficas, etc. Mas é também nessa época que se desenvolve, por razões ideológicas, o ensino de certos elementos de geografia, na escola primária, nos diferentes níveis do ensino secundário e na Universidade. As representações cartográficas do período, que eram basicamente de cunho qualitativo e ordenadas, graças ao desenvolvimento do tratamento estatístico de dados passaram gradualmente a ser de expressão quantitativa, substituindo o uso de tabelas de dados (1988, p. 3) 
Por conta disso, Martinelli (2003b) afirma que já no final do século XIX,

a cartografia temática já munida de um consistente leque de métodos de representação extravasa uma restrita aplicação científica e técnica para tornar-se progressivamente um meio de educação e de informação geral. Ela passa a ser utilizada nos atlas geográficos, nos livros texto de geografia, e até mesmo na imprensa, engendrando uma verdadeira revolução cartográfica.

Ao longo do século XX a Cartografia Temática foi se desenvolvendo e assumindo papel importante no entendimento dos territórios, seu potencial econômico, econômico e ambiental e suas qualidades socioambientais.

Segundo Queiroz (2007), foi entre as décadas de 60 e 70 que começou a surgir uma nova corrente do pensamento denominada "comunicação cartográfica". Segundo a autora diversas teorias, com diferentes eixos de pesquisa, foram sendo desenvolvidas e vários trabalhos foram apresentados no sentido de se buscar uma sistematização no estudo do processo de Comunicação Cartográfica.

Baseado em Ratajski (1978), Queiroz (2007) identifica algumas tendências que influenciaram a produção de mapas com base científica, com destaque para a Teoria da Comunicação, a Teoria da Modelização, a Metaciência, a Teoria da Cognição e a Semiologia.

A teoria da Informação é uma teoria matemática e destina-se a solucionar o problema da comunicação de sinais por um esquema simples de relações: emissor-mensagem-receptor, assim como dos elementos que atuam nesse processo (ruídos, redundância, variedade ou quantidade de informação). Essa teoria influenciou a produção cartografia ao ponto de criar nova corrente de pesquisa denominada Comunicação Cartográfica, para a qual o processo de comunicação se origina, é comunicada e produz seu efeito.

A Teoria da Modelização foi primeiro apresentado por Board (1967), que propõe os mapas como modelos que representam o conteúdo essencial da realidade. Posteriormente essa teoria ganha mais espaço com o uso da tecnologia do SIG na produção de mapas. 
A preocupação da Metaciência na Cartografia estava ligada ao aprofundamento das bases teórica da ciência, essência e métodos da Cartografia, não tendo recebido muita atenção pelos estudiosos da área.

Já os trabalhos de Bertin sobre a Semiologia Gráfica aplicada à Cartografia ganhou muita repercussão. Este sistematizou a linguagem gráfica como um sistema de símbolos com significado e significante. Na Cartografia esse trabalho estabelece que os mapas constituem a parte racional do mundo das imagens. Para Bertin $(1972,1977)$ a Cartografia, como linguagem universal, não convencional, é, por excelência, monossêmica.

Explica Martinelli (2003c), baseada em vários autores como Bertin (1975); Gimeno (1980), Martinelli (1998, 1990) entre outros, que cabe essencialmente à Representação Gráfica transcrever as três relações fundamentais:

... de diversidade, de ordem e de proporcionalidade, que podem ser estabelecidas entre objetos por relações visuais de mesma natureza. A transcrição gráfica será universal, sem ambiguidades.

Assim, a diversidade será transcrita por uma diversidade visual, a ordem, por uma ordem visual, e a proporcionalidade, por uma proporcionalidade visual. Saber coordenar tais orientações significa dominar a sintaxe dessa linguagem" (MARTINELLI, 2003c, p. 14).

A Teoria Cognitiva, por sua vez, foi desenvolvida a partir da Psicologia, trazendo conhecimentos importantes para a Cartografia, não só para o ato de conceber o mapa que requer uma compreensão cognitiva para quem se destina, como do usuário receptor que terá uma importante ferramenta para interpretar a realizada vivida. Evidencia-se, assim, o caráter cognitivo tanto do cartógrafo quando do propenso leitor/usuário (QUEIROZ, 2007, p. 141).

Vários autores desenvolveram trabalhos sobre o processo cognitivo da produção e do entendimento dos mapas (PETCHENIK, 1977, 1985; OLSON, 1979; LOYD, 1988, 2000; MONTELLO, 2002; entre outros). No Brasil, os trabalhos de Lívia de Oliveira (1978) são pioneiros sobre o ensino da cartografia para crianças, com fundamentação piagetiana. Depois o trabalho de Simielli (1993) se notabilizou por sistematizar um conjunto de conceitos relacionados à alfabetização cartográfica, o qual organiza um esquema de representação do espaço geográfico, fundamentado no desenvolvimento cognitivo (QUEIROZ, 2007, p. 141- 
142). Outros autores trabalham nessa perspectiva, principalmente a partir do avanço das novas tecnologias da educação e da informática.

A Cartografia, de modo geral, é tratada e concebida nos dias de hoje, dentro do que se conveniou chamar Era da Informação. Nesses novos tempos o uso de computadores e softwares de Sistemas de Informação Geográfica (SIG ou GIS, em inglês: Geographical Information System) são muito comuns e amplamente utilizados nos cursos de Geografia e Engenharia Cartográfica. O uso dos SIG leva a uma agilidade na produção de mapas, principalmente aqueles com finalidade temática. Autores como Martinelli, contudo, têm alertado para o abuso no uso da informática e dos softwares, no sentido de que a grande produção de mapas não significa, necessariamente, qualidade. Isto porque a maioria não atenta para a preocupação com processos da lógica da informação, por exemplo. $\mathrm{O}$ destinatário final, o usuário, não consegue "ler" o mapa, muito menos "compreender" o mapa, na concepção defendida por Martinelli (2003).

Nesse contexto, isso nos leva à discussão e a um debate sobre o tema da Visualização cartográfica, discutido por Taylor (1994). Para o autor, esse é um conceito central, unido à interação e à animação, afetando diretamente a cartografia em três aspectos principais, que são as técnicas de produção cartográfica (com novas técnicas computacionais e de multimídia), a comunicação e a cognição/análise (QUEIROZ, 2007).

Para Taylor (1992): "Visualização é um instrumento científico, mas demanda habilidades, imaginação e intuição na sua aplicação" (p. 16).

Figura 18 - Bases conceituais da Cartografia

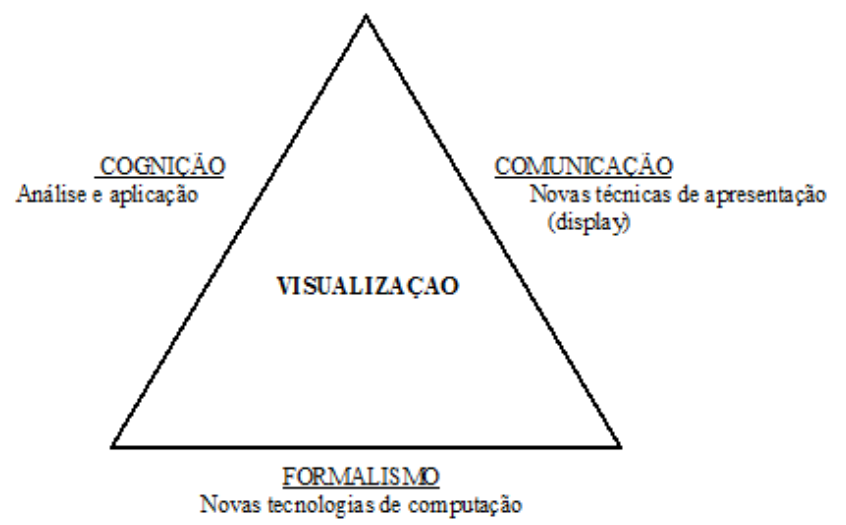

Fonte: baseado em Taylor (1992) 
Para o autor, se a cartografia tem que progredir todos os três lados do triângulo também devem. Para ele as novas tecnologias são de grande importância para a cartografia, mas não podem ser excluídas a cognição e a comunicação.

Taylor finaliza sua discussão com uma afirmação importante:

Com uma base conceitual revitalizada, a Cartografia, evidentemente, tem um futuro promissor. Em alguns aspectos, nós demos uma volta completa. A cartografia moderna cada vez mais se encontrará na interface de arte e ciência, e ambas, criatividade e imaginação, serão exigidas para complementar as técnicas científicas de sofisticação crescente. Ao mesmo tempo, a disciplina cada vez mais se destacará pelo reconhecimento das consequências sociais e culturais dos mapeamentos, e pela necessidade de se examinar mais cuidadosamente todo um conjunto de questões relacionado à Cartografia no seu contexto social, tanto dentro como entre sociedades diferentes (TAYLOR, 1992, p. 18).

Nota-se uma clara divergência teórica das pesquisas em Cartografia baseadas nas concepções acima aludidas. Vista desta forma, parece haver uma oposição entre esses autores e suas teorias no entendimento do processo de comunicação cartográfica. Bertin, por exemplo, diverge dos adeptos da teoria da Informação ao formular uma linguagem gráfica que não é regida pela arbitrariedade, nem pela linearidade, como propõe o esquema básico de transmissão da informação (emissor-código-receptor) para a informação cartográfica. Contudo todas elas têm alguns fatores em comum como a presença da realidade, o criador dos mapas, o usuário dos mapas e a imagem da realidade, que de uma forma ou de outra, de maneira muito teórica ou prática, tem colaborado para o desenvolvimento da Cartografia Temática (QUEIROZ, 2007).

Martinelli é um dos grandes divulgadores da teoria da Representação Gráfica. Defende que a produção cartográfica, nessa concepção, deve ser uma linguagem destinada à vista, mais importante que para a leitura. Como linguagem é um sistema de signos para a comunicação social, porém com um único significado (monossêmico).

A tarefa essencial da Representação Gráfica é transcrever as três relações fundamentais entre objetos (no caso dos mapas são os lugares) por relações visuais de mesma natureza. A transcrição será universal, sem ambiguidades, como nas equações matemáticas (MARTINELLI, 1994, p. 64) 


\subsection{Rumo a uma Cartografia do Meio Ambiente e do Turismo}

A proposição aqui exposta é a de se traçar uma imagem da realidade do município de Parintins a partir da Cartografia, tendo como ideia inicial fazer uma exposição das diversas características físicas, ambientais e socioeconômicas do referido município para depois realizar uma cartografia de síntese, baseada na proposta defendida pelo professor Marcello Martinelli (2003, 2003b, 1996, 1994) e Queiroz Filho e Martinelli (2007).

Um dos primeiros problemas enfrentados está na questão da escala. A escala remete a uma relação espacial de grandeza entre o real e o desenho (mapa) e a escala cartográfica representa essa relação proporcional e representa o número de vezes que o espaço foi reduzido no mapa.

O outro sentido de escala se refere a qualidade das informações contidas ou a capacidade que tem o mapa de mostrar a realidade que se quer vislumbrar. A essa escala denomina-se escala de análise ou geográfica.

Para alguns autores, a Geografia tem se utilizado da escala geográfica, pois esta é uma escala atrelada ao tempo, que valoriza o processo e não a coisa estática, o fenômeno (MACÊDO, 2009).

Nessa perspectiva, a delimitação da área de estudo está bem definida como sendo o município de Parintins. Todavia, na metodologia aqui empregada não se pode perder a noção de que o referido espaço está inserido dentro de um contexto regional, nacional e mesmo mundial.

Em uma discussão durante um Congresso de Cartografia, Zacarias, Martinelli e outros (2009) apontam para a importância de se definir a escala de análise geográfica. Para eles os fenômenos geográficos acontecem em diversas escalas, mas sua percepção depende da escala em que se trabalha. Essa escala dos fenômenos que se dão no espaço é geográfica, apesar de sua representação ser feita por meio da cartografia. A compreensão geográfica do fenômeno leva em consideração uma escala espacial, que é a extensão onde o fato ocorreu, como também, uma escala temporal, relacionada ao tempo de ocorrência de um fenômeno e o tempo de resposta que os organismos dão face a este. 
O mapa proposto é um mapa ambiental, por se tratar da representação de uma região reconhecida pela sua grande biodiversidade, a Amazônia. Um mapa ambiental é mais bem representado em um mapa de síntese. Segundo Martinelli (2003, p. 131):

A cartografia de síntese concebe mapas ditos de síntese. Eles não trazem mais elementos em sobreposição ou em justaposição como nos mapas analíticos, mas sim a fusão deles em 'tipos' - unidades taxonômicas. Estas agrupam lugares caracterizados por agrupamentos de atributos ou variáveis.

A região Amazônica, devido a sua extensão, é composta por um intrincado mosaico de ambientes, definido não só pela heterogeneidade dos seus ecossistemas como também pelo processo de ocupação e desenvolvimento. O espaço amazônico pode ser visto como um espaço segmentado e organizado de acordo com usos e processos de ocupação, assumindo, assim, diferentes identidades socioeconômicas e institucionais. É preciso compreender que essa forma de ver a Amazônia é importante nos processos de tomada de decisões no planejamento regional, evitando generalizações e considerando as especificidades locais de cada região.

O objetivo a seguir é mostrar em mapas as características físicas e ambientais do município de Parintins. Os mapas temáticos darão suporte para propor, ao final, um mapa síntese apresentando uma divisão ambiental e turística do município.

Foram utilizadas bases cartográficas do Instituto Brasileiro de Geografia e Estatística (IBGE, 2010), da Companhia de Pesquisa e Recursos Minerais (CPRM, 2010) que elaborou um importante documento denominado Biodiversidade do estado do Amazonas com seus resultados e mapas disponíveis em CD, e do Sistema de Proteção da Amazônia (SIPAM). Os dados foram trabalhados em um software de Sistema de Informação Geográfica (GIS, sigla em inglês) livre, o Quantum Gis, versão 7.4.1. 
4.3.1 Mapa da bacia hidrográfica em Parintins

A grande bacia amazônica já foi bastante estudada e caracterizada (IBGE, 1991; SIOLI,1985; SALATI, 1983; AB'SABER, 2004, 2008; SOARES,1991). Ao analisar a expressão continental da Bacia Amazônica, Soares (1991) a classifica como a mais densa e rica rede de drenagem conhecida e que, por conta disso, a região amazônica possui o maior sistema fluvial da Terra, recolhendo grande parte da precipitação pluvial do globo, "os rios da Bacia Amazônica são permanentemente caudalosos; escoando cerca de um quinto do volume de água doce de todo o planeta, o rio Amazonas é a artéria fluvial de maior vazão já medida, carregando $15 \%$ a $20 \%$ da água que todos os rios do mundo conduzem aos oceanos" (SOARES, 1991, p.81).

Posteriormente, expedição científica coordenada pelo Instituto de Pesquisa Espaciais (INPE) estabeleceu a nascente do rio Amazonas localizada no rio Apurimac, que nasce no Peru, entre os montes Mismi (5.699 m) e Kcahuich (5.577 m), situado ao sul da cidade de Cuzco e próximo do lago Titicaca. Com essa definição do local da nascente do rio Amazonas, segundo Carvalho (2005), sua extensão até a foz foi medida em $7.100 \mathrm{~km}$, passando a ser o maior rio do mundo, não só em volume, mas também em extensão. Em outro documento, da National Geographic Society (2000), a discussão de mais de 60 anos foi superada após a revelação de que o rio Amazonas mede $7.025 \mathrm{~km}$, pelo menos 500 a mais que o Nilo (CUNHA; PASCOALOTO, 2006).

No sítio do INPE a extensão definida é um pouco menor:

O Instituto Nacional de Pesquisas Espaciais (INPE) concluiu as medições com imagens de satélites que indicam o Amazonas como o maior rio do mundo. Segundo a metodologia do trabalho coordenado por Paulo Roberto Martini, da Divisão de Sensoriamento Remoto do INPE, o Amazonas tem 6.992,06 quilômetros de extensão enquanto o Nilo atinge 6.852,15 quilômetros. (INPE, 01/07/2008, http://www.inpe.br/noticias/noticia.php? Cod_Noticia $=1501)$. 
A extensa bacia amazônica ocupa vasta área da América do Sul. São mais de 6,5 milhões de $\mathrm{km}^{2}$ de área. Nela estão encaixadas grandes bacias sedimentares do Paleozoico e do Mesozoico com reduzida ação tectônica atual, sendo poucas as manifestações tectônicas desde o Siluriano, tendo sido estabelecido seu equilíbrio por manifestações epirogenéticas e deformações locais por falhamentos de gravidades e abaulamentos. Compreende geograficamente quatro grandes unidades geotectônicas: a Bacia Sedimentar Amazônica; a Cadeia Andina e os Escudos Cristalinos das Guianas e do Brasil Central (SOARES, 1991).

Ab'Saber (2004) identifica em seu interior um dos grandes domínios morfoclimáticos brasileiros, o domínio morfoclimático amazônico, caracterizado por "terras baixas equatoriais florestadas, ou o domínio brasileiro dos 'tabuleiros' equatoriais florestados" (p.31)

O rio Amazonas é o seu rio principal e coletor, caracterizado por Soares como

do tipo sinéclise, evoluída a partir de outra do tipo rift (aulacógeno), produzida em terrenos arqueanos e proterozoicos, que acolheu espessa sequência de sedimentos paleozoicos, mesozoicos e cenozoicos; cavando desde o início o seu leito da imensa bacia detrítica suavemente inclinada para leste (SOARES, 1991, p. 73)

O rio Amazonas "possui uma drenagem nitidamente do tipo exorréico" (SOARES, 1991, p.82), que viria a se transformar, no decorrer do Quaternário, segundo Ab'Saber, em "um grande rio consequente-mestre" (2004, p. 33).

$\mathrm{O}$ rio Amazonas foi encaixado em antigos terraços, provavelmente do Pleistoceno, depois do último abaixamento do nível oceânico (SOARES, p.75). A presença de "vales afogados" ou "rias fluviais" merece importante destaque nessa análise, pois a presença deste é marcante na região e característico de rios de água preta. Foi provocado pelo processo de encaixe rio Amazonas e toda bacia após o último período glacioeustático quaternário. Essas rias fluviais são decorrentes do aprofundamento dos leitos de alguns rios durante a regressão marinha. Todavia, após o estabelecimento do atual nível do mar e seu equilíbrio, os rios tiveram seus vales finais enchidos pelas águas represadas pelo rio principal, além de seus sedimentos colmatarem boa parte de suas bocas e que são responsáveis pela construção das 
várzeas amazônicas (SOARES, 1991, p.75-76). A desproporção entre suas larguras na desembocadura, bastante extensa, chegando a quilômetros, e dos cursos de água do qual derivam a jusante, é uma das mais notórias características.

Carvalho explica o processo que dá origem às rias fluviais e das várzeas na Amazônia:

Nos períodos interglaciais o processo é inverso. A elevação da temperatura da Terra provoca derretimento do gelo retido sobre os continentes, lagos e mares glaciados, fazendo aumentar o nível das águas dos oceanos e mares. Ao elevar seu nível de água, os oceanos e mares afogam as bacias exorréicas que apresentam baixa declividade em seu curso inferior, fazendo com que os rios depositem grande parte do material transportado em seu próprio vale escavado, elevando seu nível de base e aumentando a área de transbordamento, formando planícies. Por esse processo de encaixamento e elevação do seu nível de base, o rio Amazonas formou os terraços Pleistocênicos e a atual planície de inundação, que ainda se encontra em formação." (CARVALHO, p.23).

Sioli (1985) caracteriza os rios da Amazônia em três tipos: de águas branca, clara e preta (mapa 4). Os rios de águas branca correspondem aos grandes rios com grande volume de água e capacidade de transporte e são rios mais recentes datados do Quaternário. Alguns são rios meandrosos outros mais retilíneos. Têm grande capacidade de desbarrancamento (queda de barranco ou terras caídas) e de deposição sedimentar (ilhas e praias de restinga). Por conta disso, os cursos dos rios de água branca são muito instáveis, pois estão constantemente divagando em seus sedimentos e remodelando seus leitos, sobretudo na zona de transferência e de deposição, influenciando sobremaneira no modo de vida das populações que habitam suas margens (CARVALHO, p. 32). 


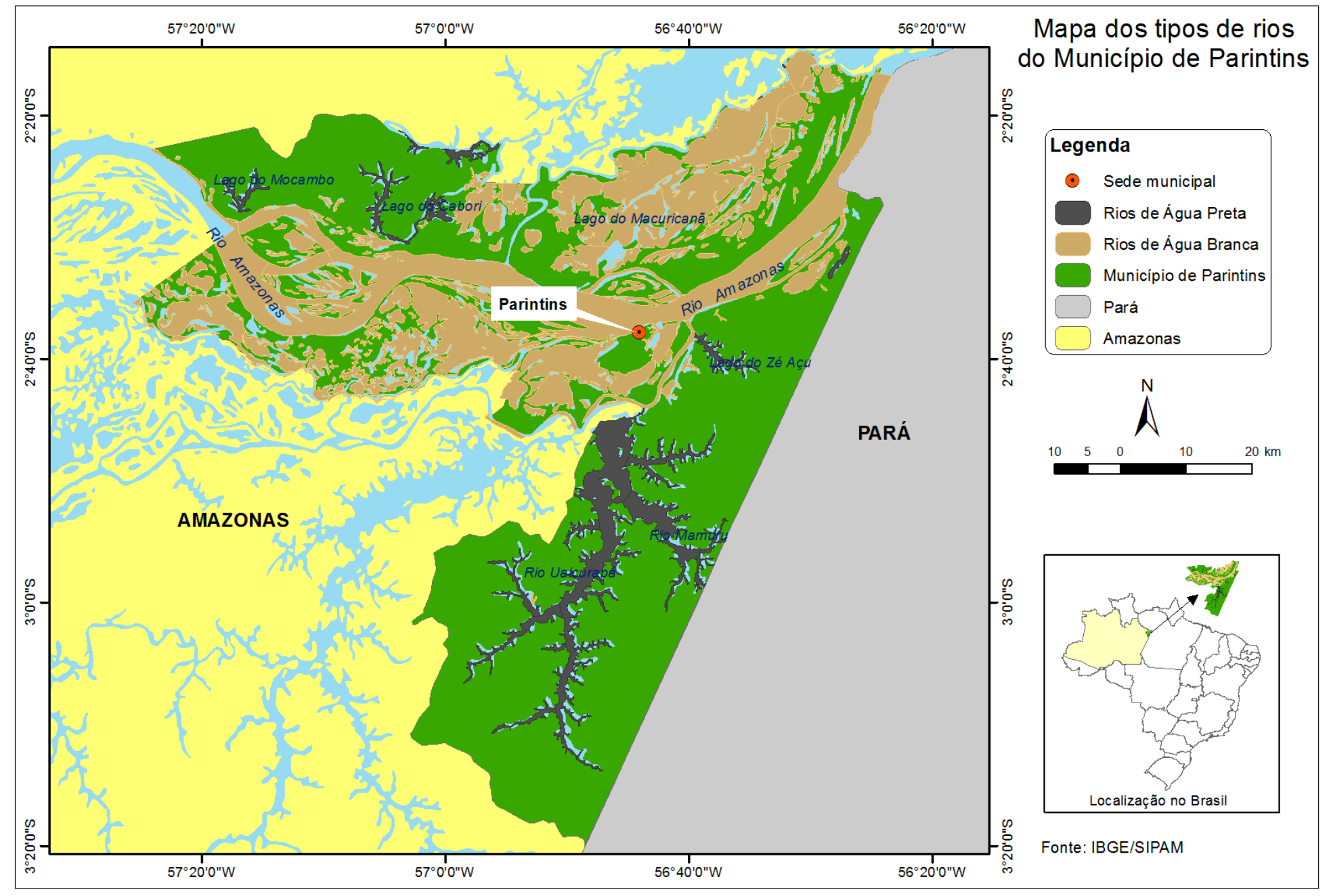

Mapa 5 - Tipos de rios da Amazônia no município de Parintins, Amazonas 
Os rios tem essa denominação "branca", mas são conhecidos regionalmente como rio de água amarelas ou barrenta, devido à grande quantidade de sedimentos que transportam. Sioli (1984) caracteriza os rios de águas brancas como sendo os

rios de águas turvas, coloração em vários matizes de ocre, ricos em material particulado em suspensão, com quantidade de eletrólitos relativamente alta, $\mathrm{pH}$ variando de 6,2 a 7,2, tendo sua origem principalmente nas montanhas Andinas. Predominantemente, são os grandes rios de origem Andina e SubAndina. Os exemplos mais notáveis desses rios são o Solimões-Amazonas, Purus, Juruá e o Madeira. No entanto, alguns igarapés (pequenos rios) que drenam áreas carboníferas durante a estação chuvosa, podem apresentar este tipo de água (SIOLI, 1984).

Os rios de água clara, por sua vez, são caracterizados pela transparência e cor esverdeada das suas águas. A origem desses rios provém dos antiquíssimos maciços do Brasil Central, os quais, em virtude do relevo mais regular, não possuem alta capacidade de erosão, embora a região não seja coberta por densa floresta protetora, mas pela vegetação aberta do cerrado. Como estas regiões estão submetidas às estações secas e chuvosas bem marcadas, esses rios só transportam quantidades maiores de material em suspensão no período das chuvas; já na longa e profunda estiagem, especialmente no Brasil Central, tais rios apresentam clareza cristalina e coloração verde-clara (SIOLI, 1984, apud CARVALHO, 2006, p.31)

Cunha e Pascoaloto (2006) em trabalho sobre a hidroquímica dos rios da região caracterizam os rios de águas claras como

rios de águas transparentes em vários matizes de verde, devido, em parte, às algas do tipo Cyanophyta, provenientes de terrenos pré-cambrianos; drenam rochas cristalinas dos escudos das Guianas e do Brasil Central. São caracterizados por uma litologia heterogênea, com pouca quantidade de material em suspensão, composição química e pH variável em função do substrato geológico $(4,5$ a > 7,0), sendo, contudo, mais pobres que os rios de água-branca. Esta categoria é representada pelos rios Tapajós, Trombetas, Xingu e o rio Curuá-Una. Além destes grandes rios, pequenos rios (igarapés) podem apresentar este tipo de água, predominantemente nas florestas de terra firme e nos campos (p.27). 
A classificação dada aos rios de águas pretas se caracteriza pela presença de rios de cor marrom-oliva até marrom-café, devido a substâncias húmicas e fúlvicas dissolvidas, essas decorrentes da vegetação e dos solos arenosos de suas margens. São bastante ácidas (pH 3,8 a $4,9)$ e bastante empobrecidas em eletrólitos. O maior exemplo desse tipo é o rio Negro. "Sua origem geológica está relacionada a sedimentos terciários e do Pleistoceno (KLINGE, 1967); basicamente a maioria dos igarapés que drenam a terra-firme da Amazônia é de águas-pretas" (CUNHA; PASCOALOTO, 2006, p. 28).

Vários autores divergem dessa classificação por a considerarem simplista, propondo outras variáveis. Todavia, o próprio Sioli explica a profundidade dessa discussão. Para ele a resposta se revela na medida em que se remonta às nascentes dos rios (SIOLI, 1985). Segundo Carvalho (2005), a tipologia dos rios amazônicos decorre da interação de diversos fatores, como: formação vegetal, formação geológica, tipos de solos entre outros. Para este, apesar da classificação de Sioli ter tido um reconhecimento acadêmico, adverte para o fato de que existem outras especificidades nos rios da região que necessitam de maior aprofundamento, reconhece que a cor das águas não é o único critério existente para caracterizar os tipos de rios, pois há outras propriedades específicas de cada rio, que são igualmente notáveis entre os tipos de rios, como por exemplo, a morfologia dos leitos.

Até chegar ao tronco principal de uma bacia de drenagem, a água precipitada escoa sobre diversas superfícies, com diferentes tipos de solos, de rochas, de vegetação e percolam subterraneamente e chegam ao rio trazendo as características químicas e físicas por onde passa. Assim, dependendo da área de drenagem do rio, vários fatores podem influenciar e determinar a qualidade da água. Neste sentido, os diferentes tipos rios da bacia amazônica são condicionados pelas formações geológicas, tipos de solos, cobertura vegetal e pela hidrodinâmica do rio. A resultante desse processo se expressa por meio dos rios de água preta, rios de água clara e rios de água branca. (CARVALHO, p.27-28)

Observando o mapa 4, podemos perceber que o município de Parintins é cortado pelo rio Amazonas, dividindo-o basicamente em parte norte e parte sul. Nas áreas de influência do grande rio, paranás e lagos nas planícies de inundação, são de águas brancas. 
A presença dos rios de água preta é mais significativa ao sul, basicamente o rio Uaicurapá e seus afluentes, como o Tracajá e o Mamuru, que tem suas nascentes nos interflúvios dos planaltos rebaixados da Amazônia (Médio Amazonas), lado sul da Sinéclise do rio Amazonas (MME. Radambrasil, 1975, Volume 10, folha SA21, p.148), ainda rios menores como o Zé Açu, e da Valéria. Ao norte destacam-se os rios Caburi e Mocambo. Esses rios estão assentados em terras altas do platô da formação Alter do Chão, em solos do tipo latossolos.

Os rios de águas claras não são encontrados nessa parte da Amazônia.

No tocante ao turismo na região a cor dos rios faz uma grande diferença. Interessa ao turismo o encontro de águas preta e branca, como do Rio Negro e Amazonas; os rio piscosos para a prática da pesca esportiva são, geralmente, de cor branca, todavia, as áreas de pesca esportiva conhecidas, como a de Barcelos, são em águas pretas. É perceptível a cor da água e a influência que causa ao observador-turista que tudo registra com sua máquina fotográfica ou mesmo na memória.

\subsubsection{Mapa da Geomorfologia}

A geomorfologia da região amazônica é identificada genericamente por Ab’Saber como "um grande anfiteatro" formado por terras baixas e cercada por formações planáltica ao norte e ao sul (2004).

No centro da bacia está encaixado o rio Amazonas cercado por terras baixas e médias. Para Ross (2005) esta é a Planície do rio Amazonas. Para este autor, diferente de seus antecessores, a região comporta uma parcela significativa de depressões marginais, ficando a planície restrita a uma faixa que acompanha as margens do rio Amazonas e de alguns de seus afluentes. Em contato com os terrenos do Planalto da Amazônia Oriental, a leste, e da depressão da Amazônia Ocidental, a oeste; sua área mais ampla situa-se na ilha de Marajó (ROSS, 2005)

Sua superfície está coberta por uma mata densa e por áreas alagadas. Nesses trechos inundados, desenvolve-se a mata de igapó e a mata de várzea. Diferentemente das matas de 
várzea, que ocorrem nas planícies de inundação de águas brancas, as de igapó, ocorrem nas terras baixas dos platôs sujeitas à inundações de águas pretas. Essas áreas são consideradas como áreas de proteção permanente (APPs).

A referida planície sofre o processo de alagamento durante a cheia do grande rio, são as várzeas amazônicas. São formações quaternárias resultado de deposições sedimentares de diferentes idades, a parte superior do terreno abriga as deposições mais recentes. Por conta disso, são encontrados os solos aluviais, gleissolos, argiloso e argilo-arenoso holocênicos (SOUZA, 1991, p. 130-131). Alguns terrenos são mais altos e por conta disso, nem sempre sofrem o processo de alagamento, exceto quando a cheia é muito grande. Soares (1991) define essas áreas como restinga, também conhecidos regionalmente como tesos (Figura 19).

As terras altas, também denominadas de terras firmes, constituem-se de terras de origem pediplanadas, dissecadas, do período Cretácio e Terciário, denominadas como Formação Alter do Chão (leste) e Solimões (mais a oeste). O solo característico dessas formações é o latossolo, solo ferruginoso, profundo, pouco fértil e pouco resistente ao intemperismo (SOUZA, 1991, p. 123).

Figura 19: Perfil esquemático das formações da planície amazônica

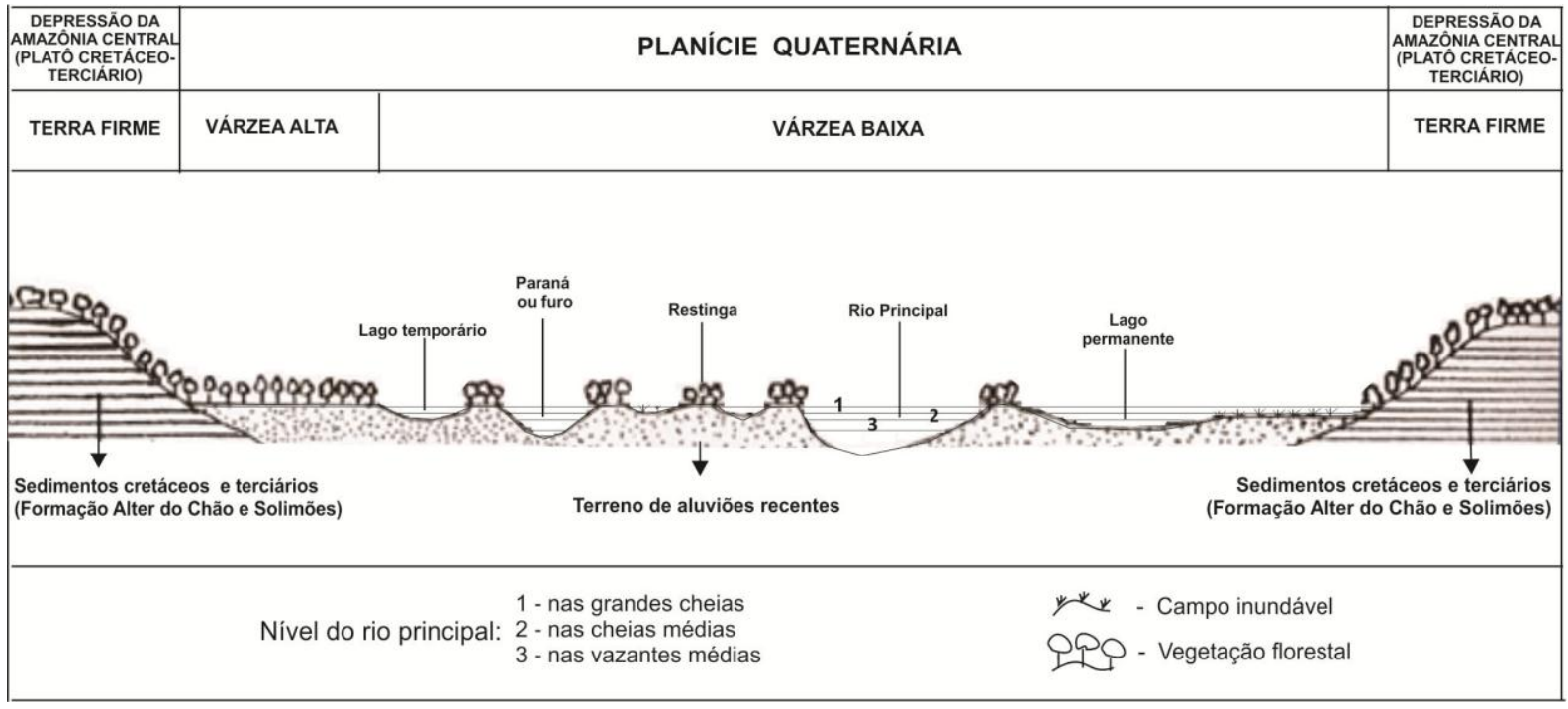

Fonte: baseado em SOARES, 1991. 
No estudo realizado sobre a geodiversidade do estado do Amazonas (CPRM, 2010), o território foi compartimentado em nove domínios geomorfológicos. Destes, apenas três unidades são de interesse desta pesquisa, a planície Amazônica e as duas unidades limites: ao norte, o Baixo Platô da Amazônia Centro-Oriental, e ao sul, o Tabuleiro da Amazônia CentroOcidental, conforme Mapa 5. Destaca-se que para a identificação das unidades geomorfológicas desta pesquisa será adotada a nomenclatura estabelecida pelo trabalho em referência para os domínios existentes no estado do Amazonas.

Segundo Albuquerque (2012), em trabalho recente na região de Parintins, essa unidade geomorfológica está diretamente submetida ao controle da ação do rio Amazonas que imprime uma dinâmica em seus períodos de água alta e baixa, formando áreas alagada e inundada. Em relação à área alagada, verifica-se que mesmo no período de baixa do nível, o rio permanece uma pequena lâmina de água recobrindo-a. A área inundável só é alagada na época da enchente do rio. Essa variação no nível do corpo hídrico na planície fluvial expõe feições geomorfológicas e morfologias lacustres, tais como: ilhas, diques aluviais, bancos de areia, restingas, paranás, furos, igarapés, vales fluviais com foz afogada ou rias fluviais, curso fluviais anastomosados, lagos circular/oval, lagos crescentes, lagos compostos, lagos dentríticos e auréola de colmatagem lacustre, dando uma diversidade de paisagem para a várzea (mapa5).

Figura 20 - Ambientes fluviais da Amazônia

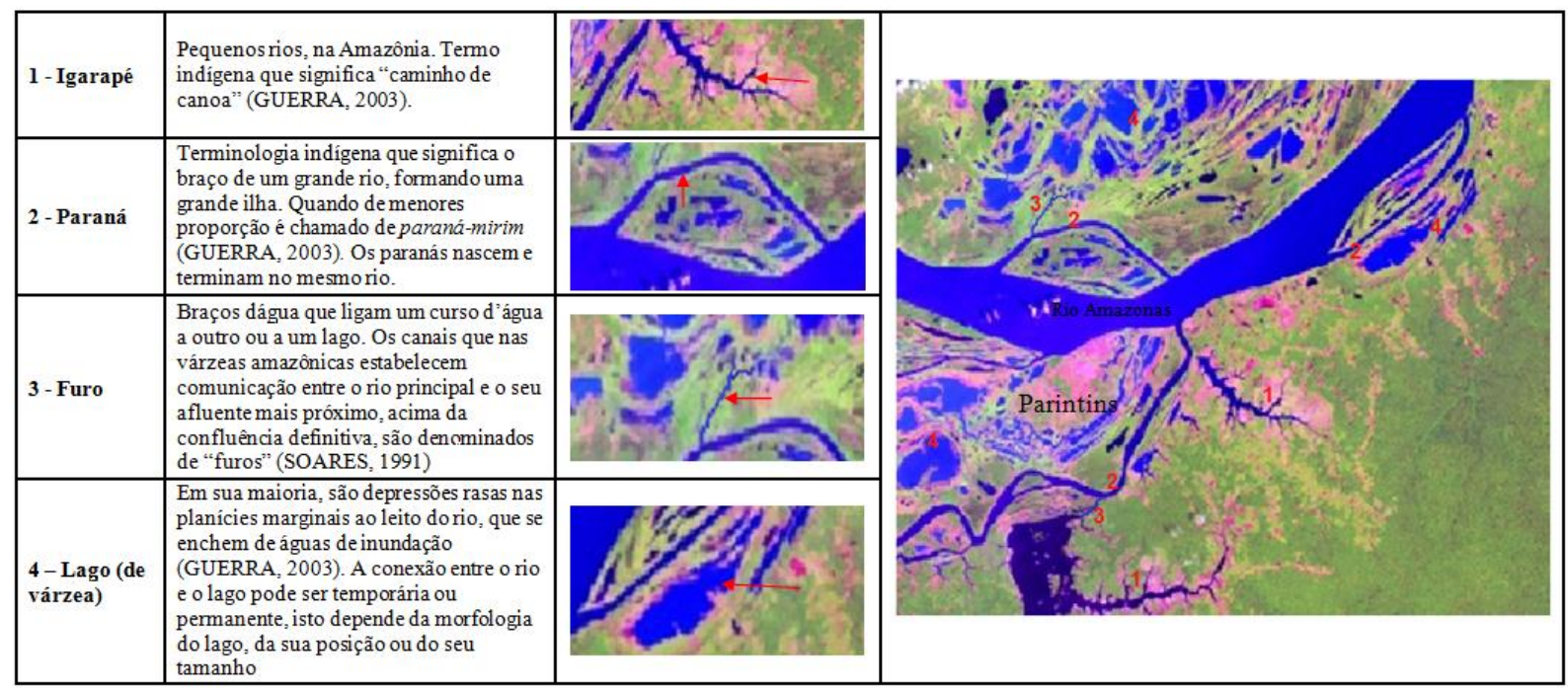

Fonte: Organizado por JDM Azevedo Filho baseado em Guerra (2003); Soares (1991); imagem LANDSAT TM (1999) 
No município de Parintins, como pode se observar no mapa 5, boa parte das terras são baixas, sujeitas à alagação. Ao norte do rio Amazonas somente uma porção mais a noroeste, onde se localiza o distrito do Mocambo e do Caburi, as terras estão fora do alcance das cheias e na parte ao sul, a cidade de Parintins, a Gleba de Vila Amazônia e região do Uaicurapá, Mamuru e Tracajá.

Em lugares pontuais na Amazônia, são encontradas as terras pretas ou terra preta de indio. As terras pretas são:

Sítios de ocupação humana pré-histórica na Amazônia são comumente encontrados próximos a cursos de água, ocupando várzeas, elevações marginais adjacentes e a terra firme interior em extensões de menos de um hectare disseminados em solos de terra firme, até vários quilômetros quadrados ao longo dos rios e interflúvios. Entre esses sítios são mais conhecidos os nominados Terra Preta (TP), além de uma variante menos evidente, a Terra Mulata (TM) (KÄMPF et al, 2009, p. 87)

Em Parintins os lugares mais conhecidos como de terra preta são a Comunidade de Santa Rita da Valéria e Terra Preta do rio Mamuru, ambas com presença de fragmentos cerâmicos, ou seja, são sítios arqueológicos. 


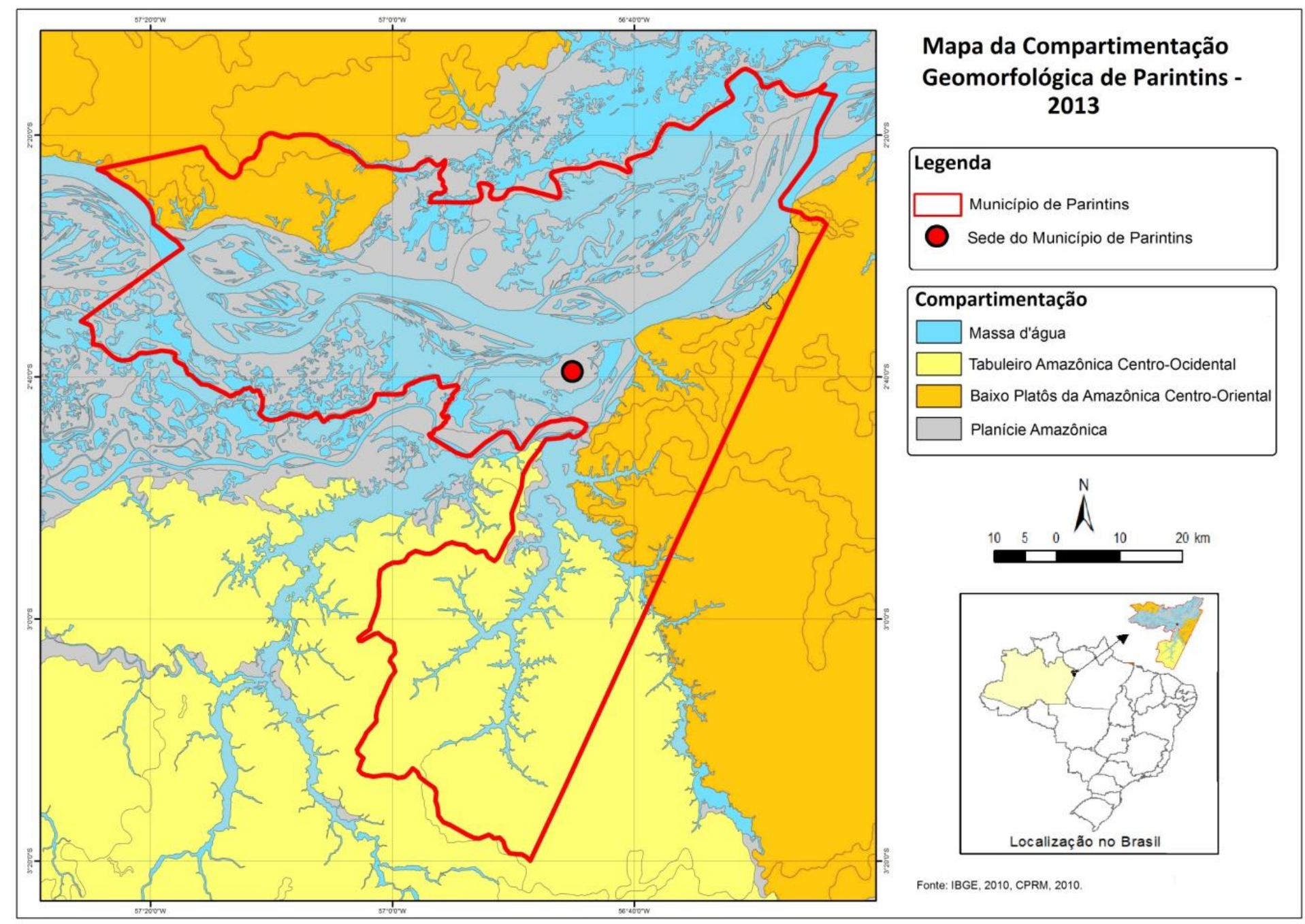

Mapa 6 - Compartimentação geomorfológica do município de Parintins, 2013 
4.3.3 Mapa dos aspectos físicos de Parintins: a vegetação

Já se falou da imensa diversidade da floresta tropical Amazônica e também que, apesar de, ao se olhar de cima, ter-se a impressão de uma homogeneidade, a floresta é um imenso mosaico de formações vegetais e ecossistemas diversos.

Desde a caracterização das florestas formadora da Hyleia amazônica, por Humboldt e Bomplant (século XIX), "uma grande diversidade de domínios florísticos foi revelada; em consequência, limites foram retificados, novos 'tipos de vegetação' foram identificados e tiveram de ser revistos" (BOHRER; GONÇALVES, 1991, p.137).

Segundo Boher e Gonçalves (1991), baseado em Drude (1889), a vegetação da Amazônia está inteiramente situada dentro da Zona Neotropical, do hemisfério sul.

Apresenta seu sistema ecológico vegetal adaptado a um clima atual definido essencialmente pela temperatura média em torno de $25^{\circ} \mathrm{C}$ e pelas chuvas torrenciais bem distribuídas através do ano, sem déficit hídrico mensal no balanço ombrotérmico anual. São exceções as áreas planálticas elevadas, que tem a sua temperatura amenizada pela altitude e, em consequência, tem a sua umidade aumentada, bem como as áreas menos úmidas à 'sombra' das serras" (BOHRER; GONÇALVES, 1991, p. 137)

Como já foi colocado anteriormente, desde a chegada dos colonizadores nesta região no século XVI, a Amazônia vem sendo cobiçada pelo imaginário de riquezas encobertas e pelo interesse de pesquisadores, naturalistas dos mais diversos ramos, do país e, principalmente, do exterior, muitos deles dedicando-se quase que exclusivamente à parte físico-botânica.

Por interesse da coroa portuguesa, Alexandre Rodrigues Ferreira, natural da Bahia, educado em Portugal, filósofo, naturalista, foi incumbido pelo governo português para comandar uma expedição científica, a primeira desse nível entre 1783 e 1789, que percorreu a Amazônia da Ilha de Marajó ao alto Rio Negro e seu tributários fronteiriços como o Uaupés, o Içana, o Ixiê e o Dimite (BORER; GONÇALVES, 1991, p.139) 
Porém, a mais notável expedição científica à Amazônia foi, segundo outros estudiosos, a realizada por Spix e Martius, de Belém até o Alto Rio Negro, entre 1819 e 1820.

Nessa viagem Martius colhe 6500 espécies vegetais, núcleo inicial da obra monumental que é a Flora Brasiliensis (Mello-Leitão, 1941). A Martius deve-se ainda a elaboração do primeiro mapa fitogeográfico do Brasil e pode-se notar que, ainda hoje, em linhas gerais, prevalece a sua divisão esquemática. Nesse mapa a Amazônia e, por extensão, a Região Norte são denominados de Nayades (cálido-quente), nome tirado da Mitologia Grega. (BORER;GONÇALVES, 1991, p. 139)

\subsubsection{Várzea e terra firme}

As planícies de inundação ou várzeas amazônicas são elementos importantes na geomorfologia e na sociodiversidade da região. Segundo Carvalho (2005), é nessa unidade geomorfológica que a dinâmica fluvial se manifesta com maior intensidade, quer seja pela erosão ou deposição de sedimentos dentro do canal, como pelos efeitos dos transbordamentos periódicos. No entanto, é nessa mesma unidade que historicamente se encontra a maior densidade da população ribeirinha (CARVALHO, 2005, p.40)

Essa expressiva planície holocênica, formada ao longo do curso médio e inferior dos principais rios de água branca, tem como maior expressão o rio Amazonas que controla essa unidade geomorfológica através da sua dinâmica e do regime fluvial, que ao transbordar deposita grandes volumes de sedimentos sobre a planície.

Carvalho (2005), baseado em Soares (1989, p.102), afirma que essa atual planície de inundação, conhecida regionalmente por várzea amazônica, forma extensas áreas baixas ao longo da calha do rio Solimões/Amazonas, perfazendo uma área estimada em $64.400 \mathrm{~km}^{2}$, o correspondente a 1,5\% da Amazônia em território brasileiro.

Gatto (1991) chama as planícies de inundação de Planícies Interioranas. Para ele, 
as Planícies Interioranas são áreas de deposição fluviais holocênicas com dimensões expressivas, localizadas ao longo dos grandes rios. De maneira geral ocorrem em todos os rios, mas assumem proporções transversais quilométricas em casos como o rio Amazonas, Juruá, Purus, Madeira e Negro. (GATTO, 1991, p.58).

As planícies, em referência, são formadas por argilas e siltes depositados por colmatagem nos lagos e terrenos periodicamente inundados, podendo apresentar também características arenosas nos diques marginais, pestanas ou pointbars, constituídos e reconstituídos a cada cheia (GATTO, 1991).

No mapa é possível perceber que boa parte do município é formada por áreas de várzea, isolando um bloco de terras altas à noroeste e outra à sudeste (Vila Amazônia) e sul (rio Uaicurapá). A cidade de Parintins, assentada numa ilha de terra firme se destaca no meio da área de várzea, na ponta a jusante da grande ilha de Tupinambarana (ver p. xx).

A várzea tem uma importância significativa para o homem amazônico, pois é nela que estes encontram boa parte do meio de subsistência na vasta região. Boa parte do seu tempo de trabalho anual é dedicada à várzea. Além do cultivo de culturas temporárias, a criação de animais e a pesca são praticados. Durante a cheia é possível a prática da pesca, todavia, alguns transmigram para áreas de terra firme.

Porro (1995) acentua que os primitivos habitantes da região ocupavam vasta área das várzeas, chegando a um cálculo aproximado de mais de 950 mil habitantes ao período do contato com os colonizadores e um total aproximado de 2 milhões para toda a Amazônia, no século XVI.

No município de Parintins, durante a cheia, período compreendido, geralmente, entre os meses de março a outubro, o rio Amazonas transborda e alaga vasta área baixa do seu entorno. Cerca de $30 \%$ do município é formada por áreas de várzea.

No gráfico da figura 21, referente ao ano 2011, é possível perceber que o período que começa a encher é o mês de outubro, o seu ápice, no mês de maio (8 de junho, em 2011). O transbordamento do rio Amazonas, quando começa a ocupar furos e lagos, se dá entre os meses de abril/maio até agosto/setembro. 
Figura 21 - Cota d'água do rio Amazonas em Parintins, ano 2011

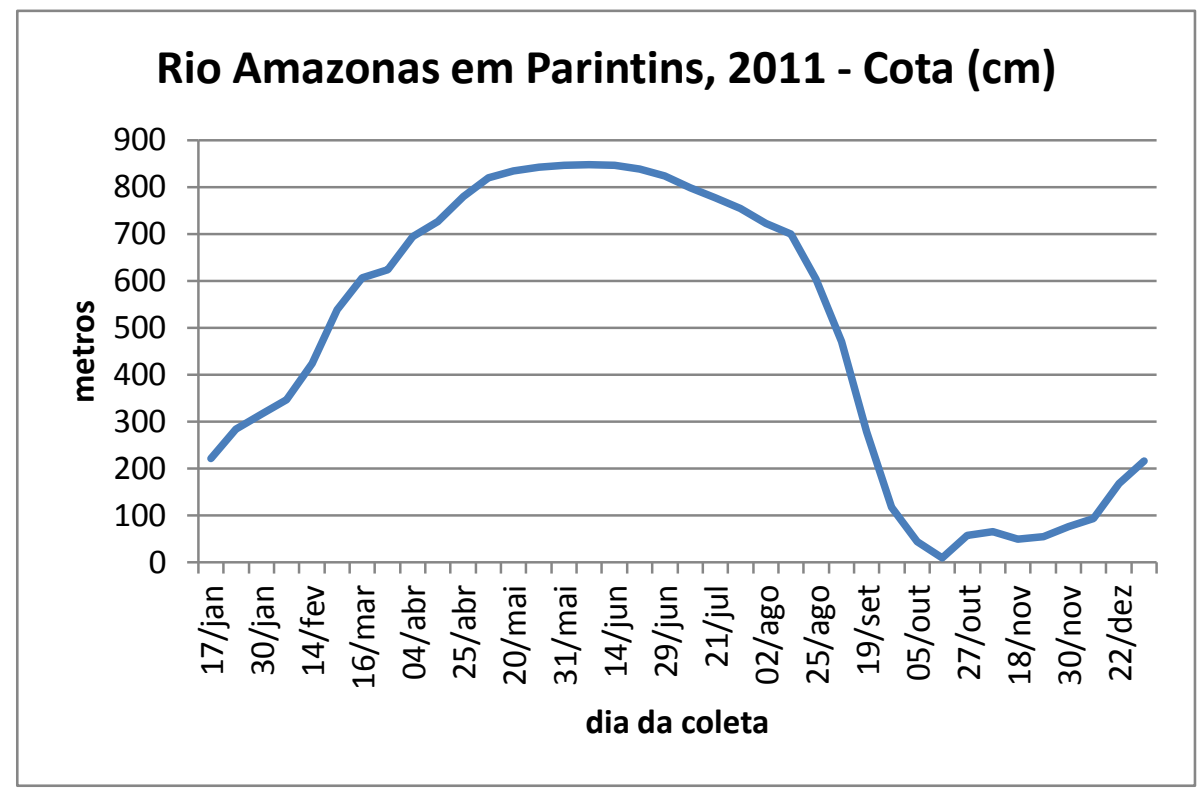

Fonte: ANA/CPRM/SIPAM, Boletins de Monitoramento, 2011.

Organização: JDM Azevedo Filho 


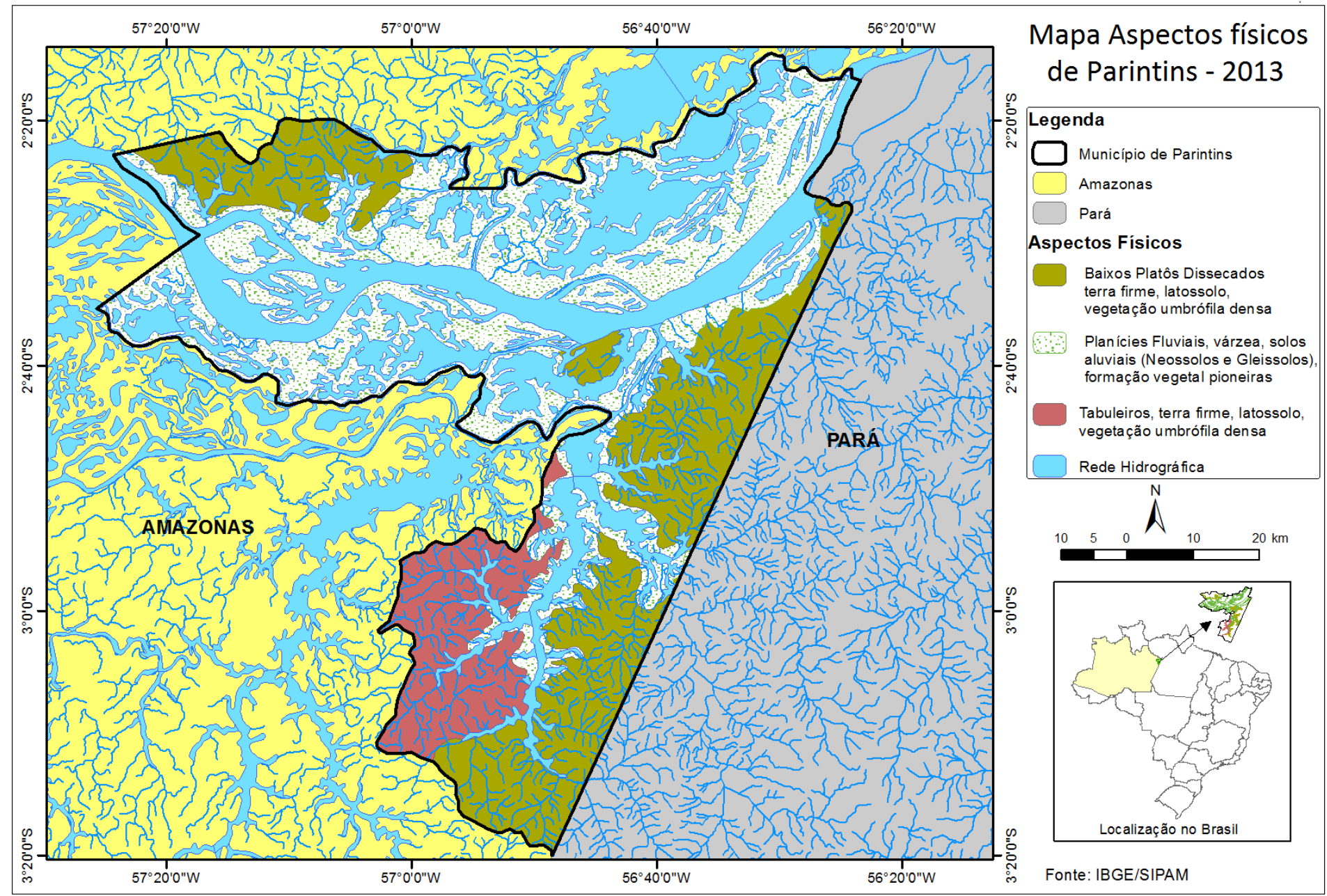

Mapa 7 - Aspectos físicos de Parintins, Amazonas. 
Os contrastes entre o período da cheia e da vazante na região:

Figura 22 - Parintins: distinção entre o período da enchente e da vazante dos rios da Bacia Amazônica

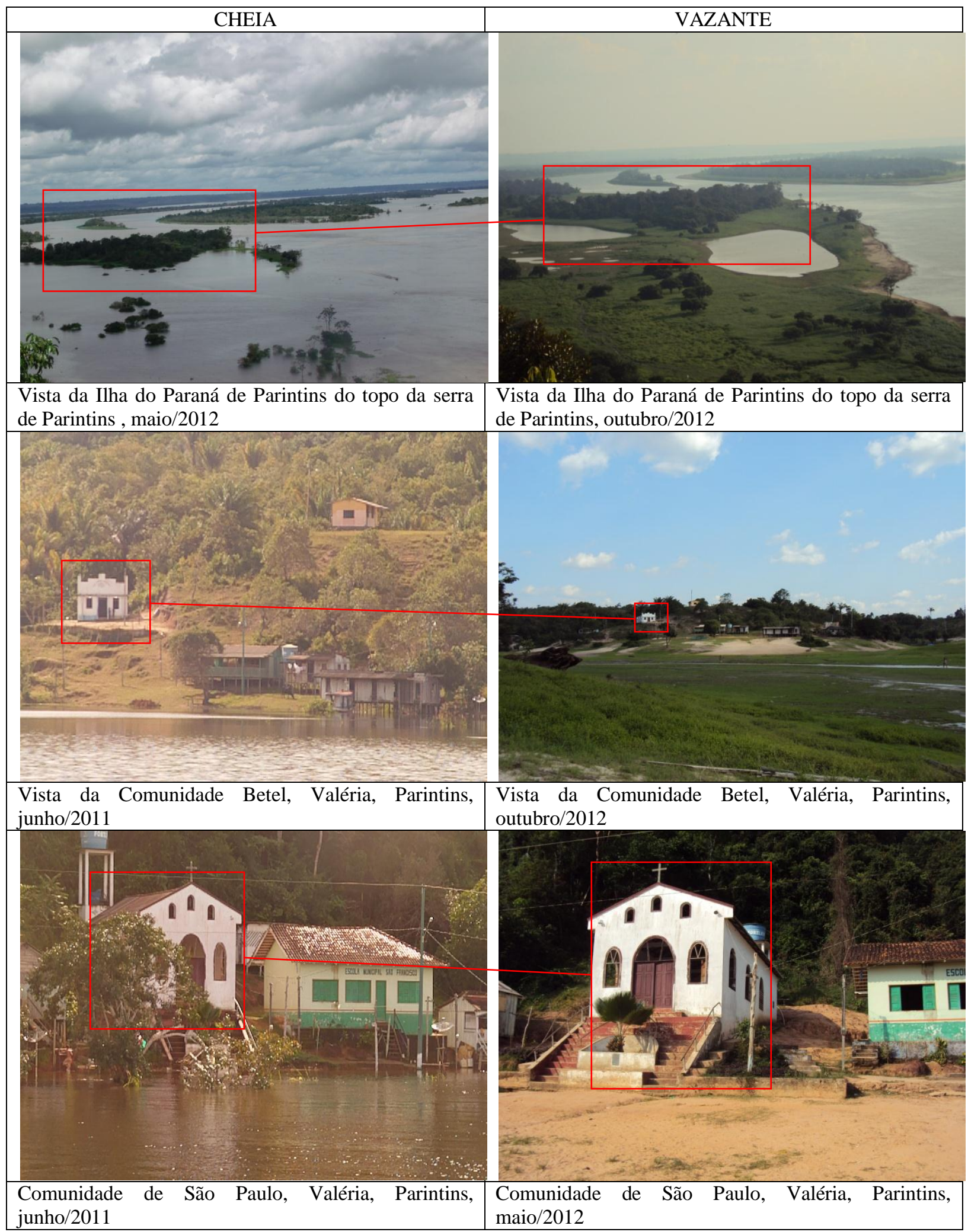

Fonte: acervo de JDM Azevedo Filho 
Os lagos de várzea formados nos baixios do rio Amazonas tem como característica serem área de reprodução de peixes durante a cheia e ficarem isolados durante a vazante, chegando alguns a secar totalmente. Nesse contexto, destaca-se o complexo de lagos do Macuricanã, localizado ao norte do rio Amazonas, em boa parte dentro da Área de Proteção Ambiental do Nhamundá.

Vale ressaltar que o período da enchente dá às localidades amazônicas uma característica cênica impressionante, pois permite um acesso maior e mais rápido aos diversos pontos desse espaço, além de permitir uma percepção maior da presença da flora e da fauna da região. Os ribeirinhos por sua vez, em boa parte, deixam a área de várzea e procuram meios de sobrevivência na cidade ou em áreas de terra firme.

Mas não se pode pensar que o período de vazante é um momento negativo ou feio da região. A vazante também tem sua beleza, pois ocorre nesse período a formação de lagos em toda a região, favorecendo a aves e outros animais procriarem devido a facilidade de encontrar alimento, principalmente o peixe. As várzeas são abundantes e fartas, a presença de animais de criação nestas áreas é notória. A pesca é um dos pontos fortes desse período e a agricultura de ciclo curto como a melancia, feijão, milho e agroindustrial, como a juta e malva são praticadas nas áreas de várzea (Figura 22).

\subsubsection{Assentamento rural}

Para pensarmos em uma atividade turística voltada ao meio rural, torna-se relevante analisar a organização de assentamentos rurais no município. O município de Parintins possui dois assentamentos rurais promovidos pelo Instituto de Colonização e Reforma Agrária (INCRA). O primeiro é o Projeto de Assentamento de Vila Amazônia (PA Vila Amazônia) constituído em 1988, em uma área de 76.107 hectares e 1777 famílias assentadas (INCRA, 2011) com o objetivo de assentar 2478 famílias. O PA Vila Amazônia está localizada em uma extensão de terras altas a jusante da cidade de Parintins, na confluência da desembocadura do Paraná do Ramos com o rio Amazonas estendendo-se até os limites com o estado do Pará. A Vila Amazônia tem sua história associada ao assentamento destinado aos migrantes japoneses nos anos 1920 e que se estendeu até o período da Segunda Guerra Mundial quando o governo 
Vargas mandou extinguir o assentamento e prender os japoneses. O período de ocupação da vila pelos japoneses é caracterizado pela introdução e desenvolvimento da cultura da juta na região.

Quadro 3 - Projetos de Reforma Agrária - INCRA - Parintins - AM

\begin{tabular}{|c|l|c|c|l|l|l|l|l|}
\hline Nome do Projeto & $\begin{array}{l}\text { Área } \\
\text { (ha) }\end{array}$ & $\begin{array}{l}\mathbf{N}^{\mathbf{o}} \mathbf{d e} \\
\text { Famílias } \\
\text { (capac.) }\end{array}$ & $\begin{array}{l}\text { Famílias } \\
\text { assentadas }\end{array}$ & Tipo & $\mathbf{N}^{\mathbf{0}}$ & Data & Forma & Data \\
\hline $\begin{array}{c}\text { PA VILA } \\
\text { AMAZÔNIA }\end{array}$ & 76.107 & 2.478 & 1.777 & Portaria & 1404 & $26 / 10 / 1988$ & Desapropriação & $25 / 09 / 1987$ \\
\hline $\begin{array}{c}\text { PAE ILHA DO } \\
\text { PARANÁ DE } \\
\text { PARINTINS }\end{array}$ & 2.163 & 60 & 53 & Portaria & 061 & $06 / 12 / 2007$ & Desapropriação & $25 / 09 / 1987$ \\
\hline
\end{tabular}

Fonte: MDA/INCRA, relatório nº. 0227, 18/08/2011

O segundo é o Projeto de Assentamento Agroextrativista da Ilha do Paraná de Parintins (PAE Ilha do Paraná de Parintins), criado em 2007 em uma porção de terras de várzea localizado em uma ilha entre o rio Amazonas e o Paraná de Parintins, a jusante da cidade de Parintins, cerca de $15 \mathrm{~km}$. Como pode ser observado no quadro 3 , a área corresponde a 2.163 hectares de terra, com 53 famílias assentadas (INCRA, 2011). Segundo Pereira (2004), dedicam-se à agricultura, à criação de bovinos e de abelhas.

Os projetos de assentamento do INCRA são as áreas principais, quando se refere a essa modalidade de planejamento e uso da terra. Todavia, a história de ocupação do município deu às vilas de Mocambo e Caburi a categoria de "agrovilas", com assentamento de famílias para a produção e o abastecimento da cidade de Parintins e outras cidades próximas. Apesar de hoje as duas vilas não produzirem o suficiente nem para abastecer suas sedes, que já se tornaram grandes para os padrões do município e reivindicam o título de "cidade", as duas comunidades formam o Distrito do Mocambo, criado em 1991, por ato constitucional. 


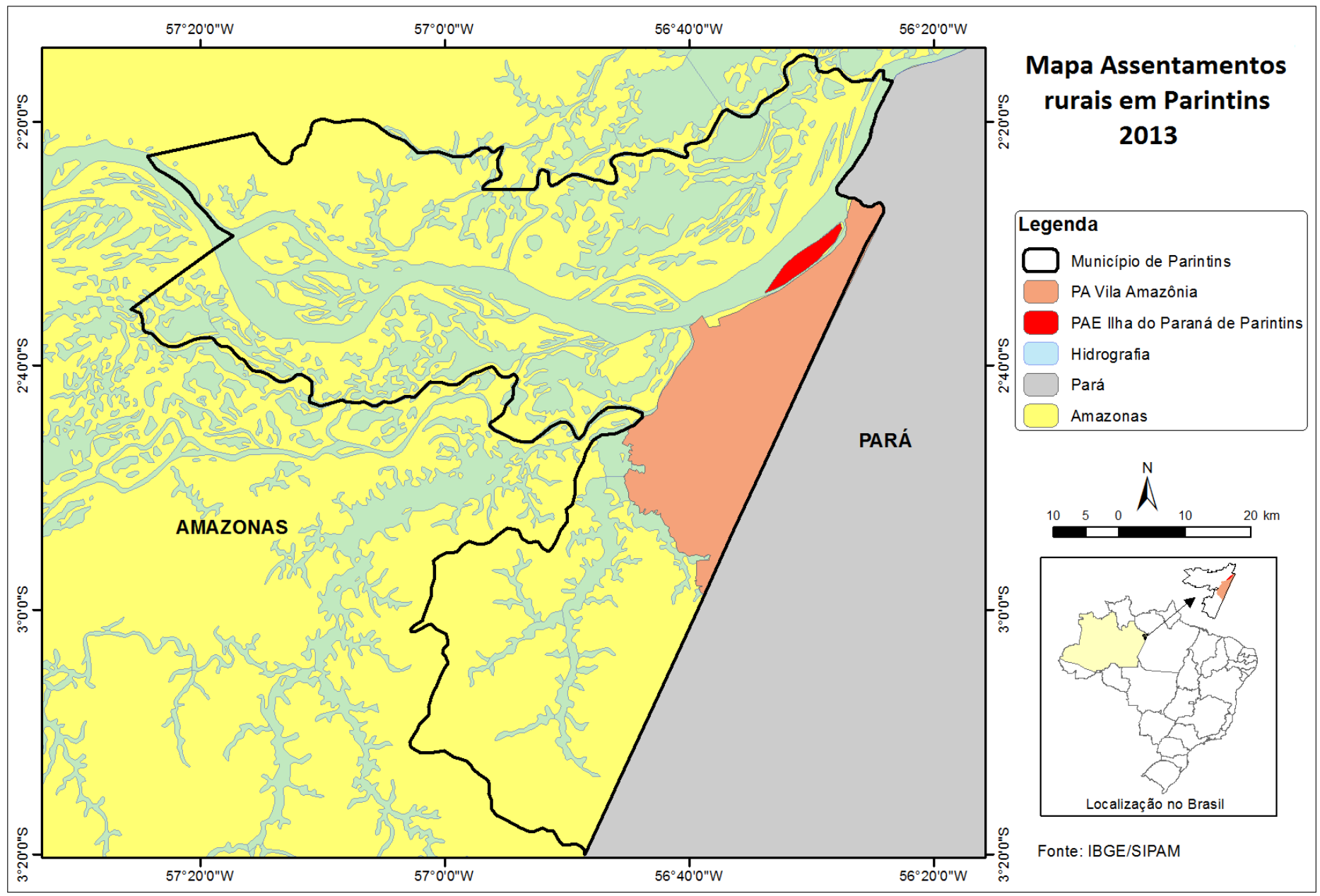

Mapa 8 - Assentamentos Rurais em Parintins 


\subsubsection{Mapa Climático}

O clima da região Amazônica está classificado, pelo método de Köppen, como do tipo Af (sempre úmido), Am (curta estação seca), Aw (inverno seco) e caracterizado como Equatorial Quente, superúmido (sem seca e subseca) a úmido (um a três meses secos), conforme classificação das Unidades Climáticas do Brasil (IBGE, 1990). Este clima é resultante da combinação de diversos fatores, dos quais o mais importante é a disponibilidade de energia solar, através do balanço de energia. Medidas realizadas na Amazônia Central (Manaus-AM) indicam que os maiores totais de radiação que chegam à superfície ocorrem nos meses de setembro/outubro, sendo que os mínimos são nos meses de dezembro a fevereiro.

A distribuição sazonal da precipitação pluviométrica na Amazônia apresenta diferenças marcantes, principalmente, entre o norte e o sul, mas também entre o leste e o oeste. A precipitação média é da ordem de $2200 \mathrm{~mm} / \mathrm{ano}$, onde o máximo pluviométrico é observado de dezembro a março (Figura 23).

Figura 23 - Variação sazonal da temperatura e precipitação na cidade de Parintins

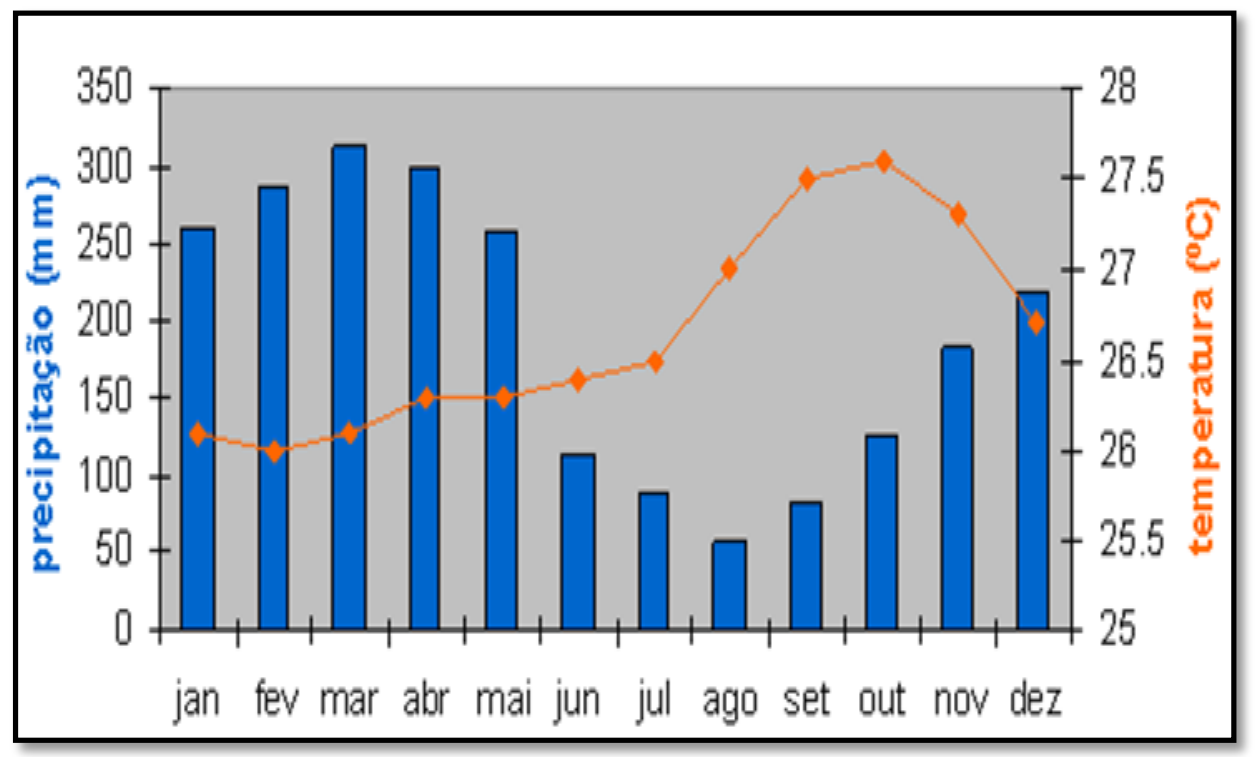

Fonte: INMET, 2011. 


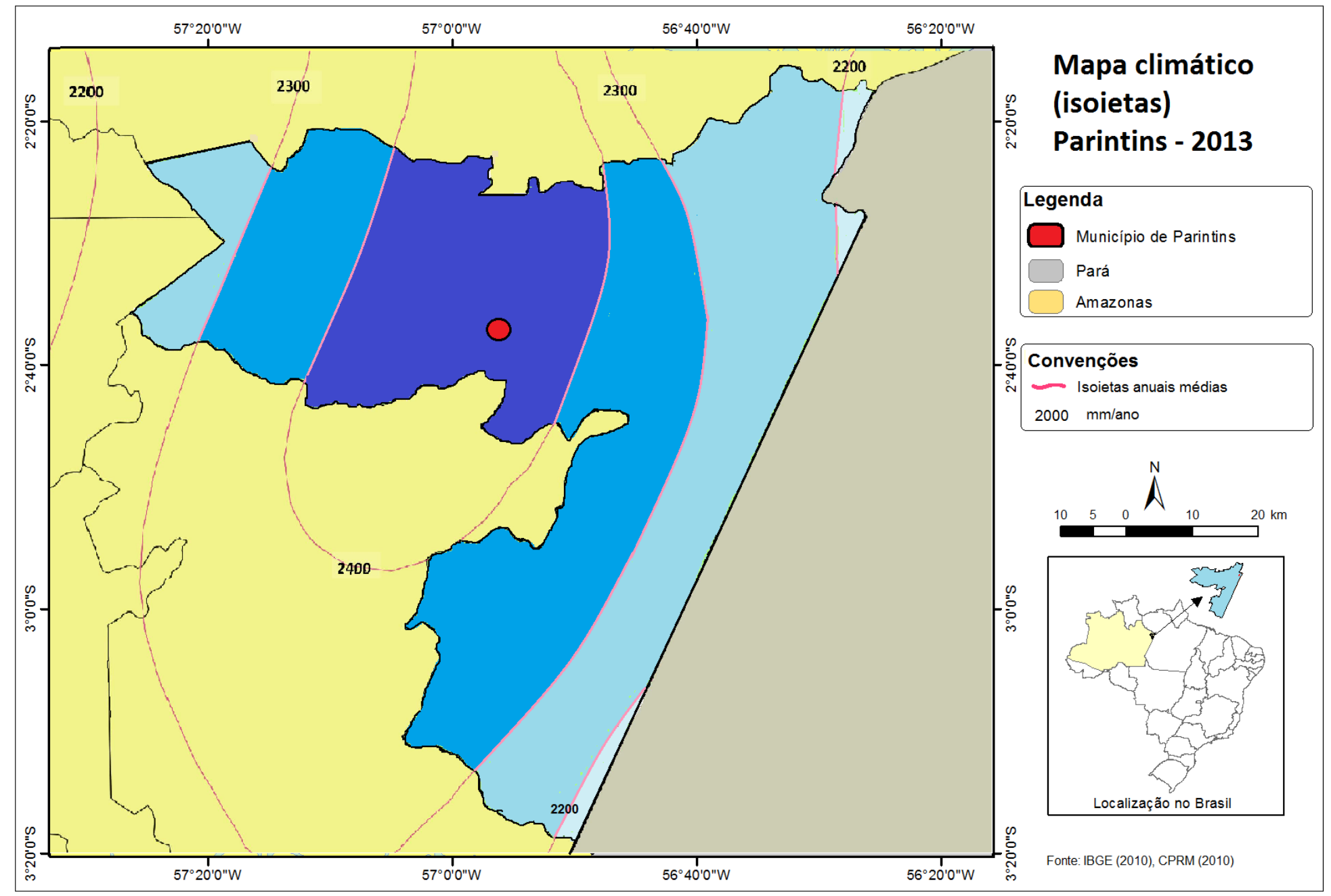

Mapa 09 - Clima de Parintins (isoietas anuais médias), 201 
Segundo a classificação de Köppen, o clima do tipo “Am”, apresenta estação seca de pequena duração, mas que não tem nenhuma influência significativa no comportamento da vegetação, em consequência dos elevados totais de precipitação que permitem uma distribuição uniforme e suficiente da umidade necessária ao desenvolvimento e manutenção das florestas tropicais. No período de estiagem, observa-se, pela manhã, água nas folhas da vegetação, caracterizando a influência do orvalho da noite na manutenção da umidade das plantas.

Em Parintins, o período das chuvas se intensifica geralmente em janeiro e se prolonga até abril (Mapa 8). A temperatura média das máximas é de $31,7^{\circ} \mathrm{C}$, a mínima de $24,1^{\circ} \mathrm{C}$ e média de $27,1^{\circ} \mathrm{C}$, a precipitação anual está em torno de $2.200 \mathrm{~mm}$ (CPRM, 2005).

4.3.6 Áreas Protegidas: Unidades de conservação e Terras Indígenas em Parintins

O conceito de áreas protegidas ainda carece de melhor definição e uma regulamentação legal. Quando se referem às áreas protegidas, os especialistas englobam as unidades que compõem o Sistema Nacional de Unidades de Conservação (SNUC), as Terras Indígenas e terras tradicionais de Quilombolas e outras áreas públicas e privadas que em diversos graus possuam uma diversidade ecológica, biológica e etnológica.

No município de Parintins há somente uma unidade de conservação, a Área de Proteção Ambiental Estadual do Nhamundá (APA Nhamundá), criada em 1990.

Uma Área de Proteção Ambiental (APA) é uma categoria de Unidade de Conservação de uso sustentável caracterizada por área extensa, com certo grau de ocupação humana, dotada de atributos naturais ou culturais importantes para a qualidade de vida das populações humanas, cujos objetivos são: proteger a diversidade biológica, disciplinar a ocupação e assegurar a sustentabilidade do uso de recursos naturais; visitação permitida; terras públicas ou privadas (Lei 9.985/2000, institui o Sistema Nacional de Unidade de Conservação). 
Criada por meio do Decreto $\mathrm{n}^{\circ}$. 12.836, de 09 de março do ano de 1990, com uma área de 195.900 hectares, a APA Nhamundá se localiza no extremo leste do Estado do Amazonas, em um espaço físico ao norte do município de Parintins e ao Sul do município de Nhamundá. Contém dois ecossistemas distintos, um de terra firme $(15 \%)$ e outro de várzea $(85 \%)$.

A APA Nhamundá ainda não possui um Plano Gestor e consequentemente, um Plano de Manejo dos recursos naturais. No entanto, é um dos lugares em que a população local optou por um Acordo de Pesca, trabalho que foi coordenado pelo IBAMA. Os lagos mapeados pelo Provárzea/IBAMA foram 94, sendo que 45 estão destinados à manutenção (subsistência das famílias, com a venda do excedente dentro das próprias comunidades); 22 para procriação, destinados unicamente à reprodução das espécies, onde a pesca fica proibida por tempo indeterminado; e 27 são comerciais, destinados à pesca de subsistência e à pesca comercial.

A várzea, o mais rico ecossistema da bacia amazônica, predomina na referida APA. Sua paisagem se sobressai sob duas formas: uma representada pelas restingas, igarapés, furos e lagos, onde estão localizadas 25 comunidades ribeirinhas e os moradores dispersos, e a outra, formada por áreas inundadas, mesmo no período da estiagem, que são os lagos e baixios, ricos em espécies aquáticas. Essa formação é conhecido como complexo Macuricanã (SDS, 2008).

A biodiversidade da APA é de grande relevância para a conservação da biota aquática da Amazônia. Seus variados lagos são importantes abrigos para aves como o socóboi e o arapapá; mamíferos aquáticos como o peixe-boi, ameaçado de extinção e várias espécies de quelônios. Também é área de procriação de pirarucu e de jacarés.

Quanto aos aspectos naturais da APA, está localizada sobre a planície fluviolacustre formada no encontro dos rios Nhamundá e Amazonas. Sua vegetação é predominante de Floresta Ombrófila densa, fortemente influenciada pelo regime de inundação dos rios. As espécies da flora local apresentam adaptações que permitem suportar meses de alagamento e/ou submersão. Destaca-se ainda um conjunto de lagos de rara beleza denominado Complexo do Macuricanã (Mapa 09). 


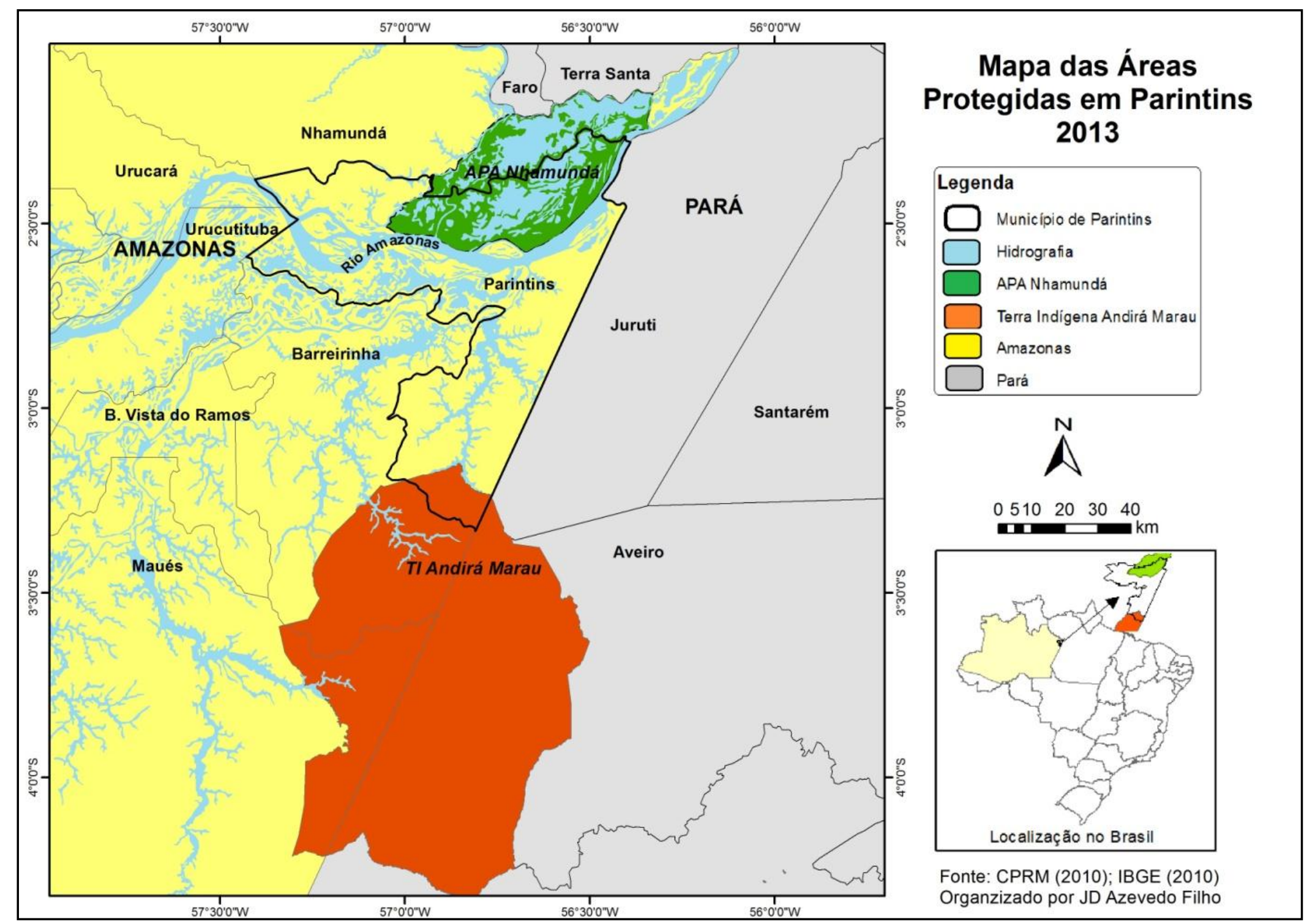

Mapa 10 - Localização de Unidade de Conservação e Terra Indígena em Parintins-AM 
Na cidade de Parintins, o Plano Diretor define 3 áreas de proteção ambiental: O lago Macurany, o Lago da Francesa e o Parananema, mas nenhum desses ganhou status de área protegida pois nenhuma lei ordinária foi criada definindo sua área ou como será implantada.

Outro tipo de área protegida existente no município é a Terra Indígena Andirá Marau. A TI Andirá Marau compreende uma grande extensão de território $(8.031,9$ km²), distribuída entre terras do Amazonas e Pará. Essas terras estão distribuídas entre os municípios de Barreirinha, Maués e Parintins, no Amazonas e Aveiros e Itaituba, no Pará. Cerca de 3,3\% das terras, apenas, estão no município de Parintins.

A TI Andirá Marau foi demarcada em 1983 e homologada em 1986, abrigando a etnia Sateré-mawé.

A Constituição Federal estabelece a possibilidade de exploração econômica da Terra Indígena, desde que autorizada pelo Congresso Nacional e ouvidas as comunidades envolvidas. Nesse sentido, tem havido iniciativas por parte de algumas comunidades em abrir parte de suas terras para visitação turística. No amazonas essa iniciativa ainda é incipiente.

\subsection{7 Áreas Urbanizadas e distribuição da população}

A área urbana de Parintins, conforme o IBGE, compreende a sede do município, a Vila Amazônia, a Vila do Mocambo e do Caburi. Nessa área moram cerca de $72 \%$ da população do município (102.033 habitantes, em 2010). Os demais se espalham em moradias dispersas e pela área rural e em pequenas vilas, aqui chamadas Comunidades.

A cidade de Parintins conta com 67.000 habitantes (IBGE, 2012). Sua área restringese à ilha que tem o seu nome. Conforme o Plano Diretor da Cidade, a área da ilha está dividida entre o perímetro urbano e a área de expansão da cidade, não havendo, portanto, setores rurais nesse espaço.

O mapa mostra a distribuição da população pelo município. As áreas de maior concentração são, além da sede municipal, as comunidades de Vila Amazônia, Mocambo e Caburi, São Tomé do Mocambo, Santa Rita de Cássia e Santo Antônio do Tracajá (Mapa 10) 


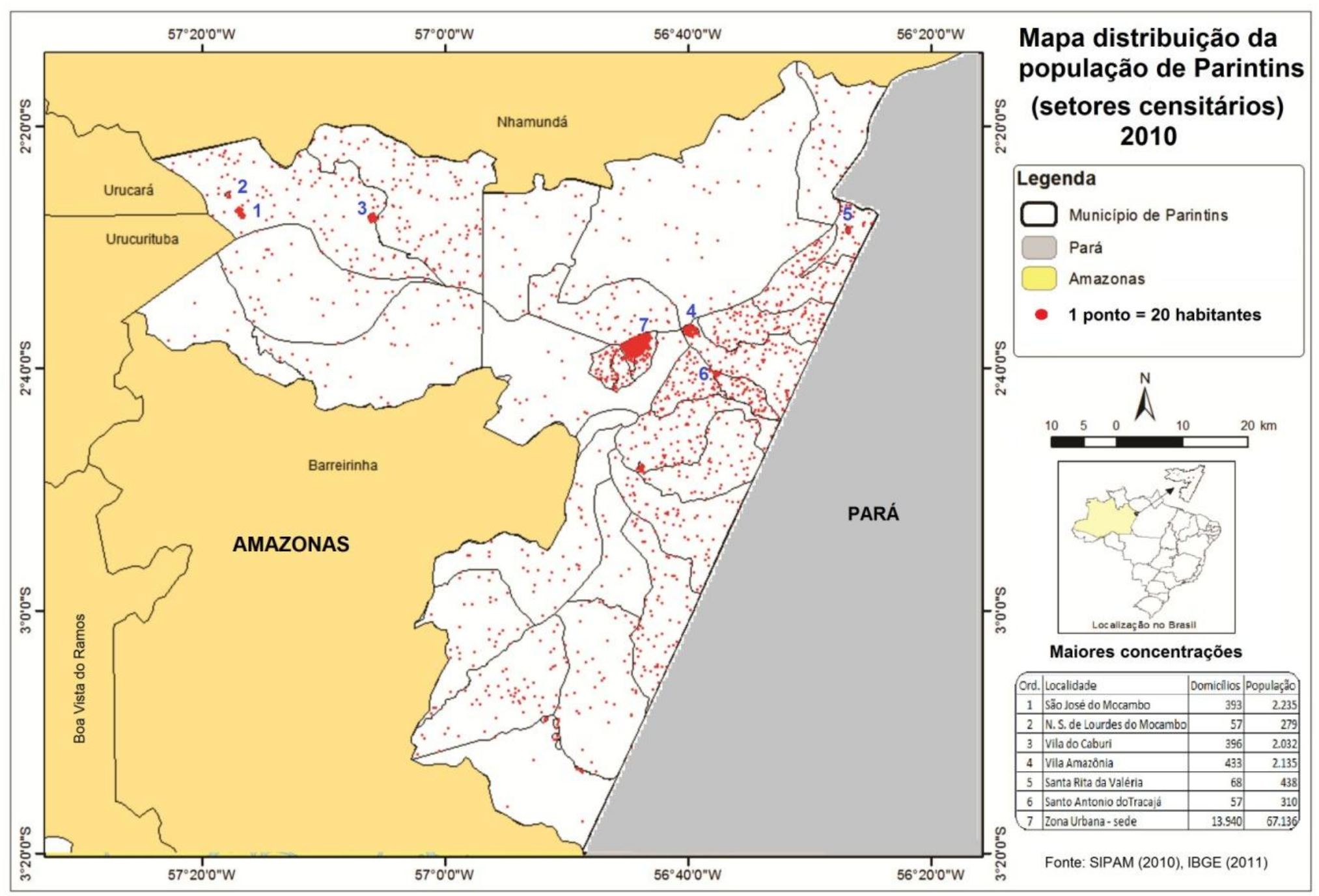

Mapa 11 - Distribuição da população em Parintins-AM, 2010 
O mapa apresenta uma distribuição aleatória dos pontos com população pelos setores censitários conforme definidos pelo IBGE, não representando a realidade, visto que a população, geralmente, localiza-se em margem de rios e pequenas comunidades em vários pontos do território.

Podemos observar, ainda, uma forte presença da população na área de assentamento da Vila Amazônia (leste/ sudeste) e no distrito de Mocambo, principalmente da parte norte. Os maiores vazios estão nas áreas de várzea e no extremo sul do município em terras indígenas.

Ao nível de rede urbana, Parintins mantém intensa relação com a sede do estado, Manaus. Como centro local, estabelece forte atração para os municípios do entorno como Nhamundá, Barreirinha e Boa Vista do Ramos. Por outro lado, de modo menos intenso, recorre ao vizinho estado do Pará para atender algumas demandas, primeiramente à Santarém e depois à Belém (figura 24).

Figura 24 - Rede urbana da Amazônia

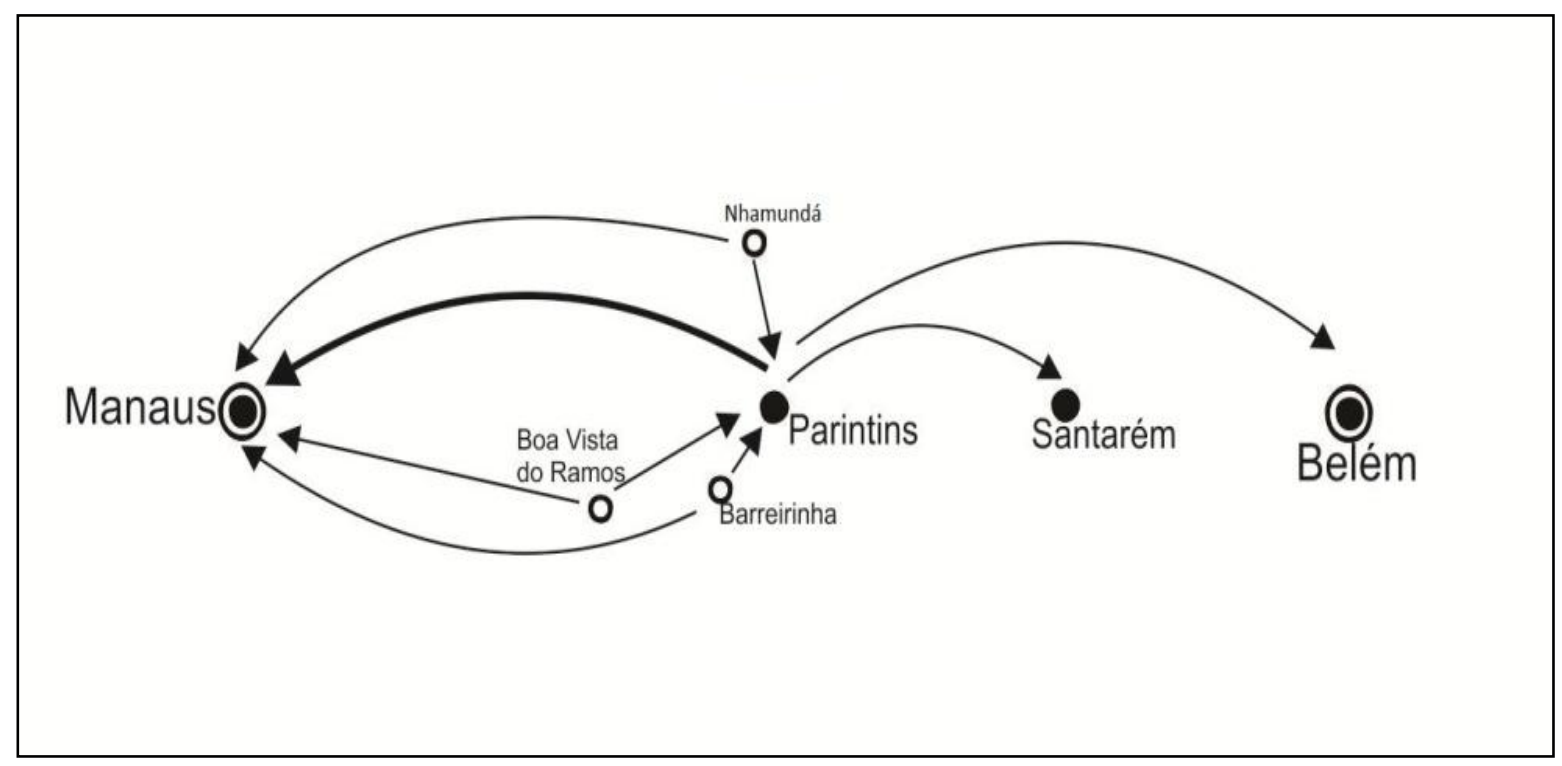

Fonte: Organizado pelo autor, baseado em Correa (1991) 


\subsection{O Mapa do Meio Ambiente e Turismo}

Considerando os diversos aspectos naturais e sociais do município apresentados nos mapas anteriores é possível sugerir um mapa de síntese delimitado por sua diversidade natural e pela importância turística.

Baseado nos ensinamentos de Martinelli (2003) podemos dar luz à representação da realidade através de um único mapa. Todavia, antes é preciso fazer algumas considerações a cerca das possibilidades de idealizar um mapa capaz de representar as diversas facetas que o movimento da sociedade representa. O próprio autor argumenta que isso não é um trabalho fácil, pois os mapas são produto da mente humana e designam produtos ausentes, além de, como já falamos, tentar representar uma sociedade em constante transformação.

Por isso, o primeiro passo ainda é sobrepor os mapas analíticos já expressos tentando neles encontrar as bases para uma cartografia de síntese. O quadro 4 expressa essa sobreposição, pois reúne as características físicas, sociais e turísticas do município. Utiliza-se aqui a divisão geográfica definida no Plano Diretor de Parintins. São 8 sub-regiões baseadas, principalmente, pela densidade de ocupação e importância econômica e política no contexto do município (Mapa 11).

Quadro 4 - Características socioambientais das sub-regiões de Parintins, 2013

\begin{tabular}{|c|c|c|c|c|c|c|c|c|c|}
\hline $\begin{array}{l}\text { SUB } \\
\text { REGIÃO }\end{array}$ & $\begin{array}{l}\text { Geomor- } \\
\text { fologia }\end{array}$ & Clima & Vegetação & $\begin{array}{l}\text { Densidade } \\
\text { demográfica }\end{array}$ & $\begin{array}{l}\text { Nível } \\
\text { desmatamento }\end{array}$ & Tipo de rio & $\begin{array}{l}\text { Nível do } \\
\text { Turismo }\end{array}$ & $\begin{array}{l}\text { Potencial } \\
\text { turístico }\end{array}$ & $\mathbf{U C}$ \\
\hline Entorno & $\mathrm{V}$ e $\mathrm{TF}$ & $\begin{array}{l}\text { Quente e } \\
\text { chuvoso }\end{array}$ & $\begin{array}{l}\text { Mata } \\
\text { pioneira/ } \\
\text { Campinarana }\end{array}$ & Alta & Alto & Branca & Alto & Alto & $\mathrm{Nd}$ \\
\hline $\begin{array}{l}\text { Gleba de } \\
\text { vila } \\
\text { Amazônia }\end{array}$ & $\mathrm{TF}$ & $\begin{array}{l}\text { Quente e } \\
\text { chuvoso }\end{array}$ & $\begin{array}{l}\text { Floresta } \\
\text { densa }\end{array}$ & Alto & Médio & $\begin{array}{l}\text { Branca (rio } \\
\text { Amazonas); } \\
\text { preta } \\
\text { (interior) }\end{array}$ & Médio & Alto & $\mathrm{Nd}$ \\
\hline $\begin{array}{l}\text { Área de } \\
\text { várzea }\end{array}$ & $\mathrm{V}$ & $\begin{array}{l}\text { Quente e } \\
\text { chuvoso }\end{array}$ & Mata pioneira & Baixo & Baixo & Branca & Médio & Alto & APA \\
\hline Mocambo & $\mathrm{TF}$ & $\begin{array}{l}\text { Quente e } \\
\text { chuvoso }\end{array}$ & $\begin{array}{l}\text { Floresta } \\
\text { densa }\end{array}$ & Médio & Médio & Preta & Baixo & Médio & $\mathrm{Nd}$ \\
\hline Caburi & $\mathrm{TF}$ & $\begin{array}{l}\text { Quente e } \\
\text { chuvoso }\end{array}$ & $\begin{array}{l}\text { Floresta } \\
\text { densa }\end{array}$ & Médio & Médio & Preta & Baixo & Médio & $\mathrm{Nd}$ \\
\hline Mamuru & $\mathrm{TF}$ & $\begin{array}{l}\text { Quente e } \\
\text { chuvoso }\end{array}$ & $\begin{array}{l}\text { Floresta } \\
\text { densa }\end{array}$ & Baixo & Baixo & Preta & $\begin{array}{l}\text { Baixíssi } \\
\text { mo }\end{array}$ & Médio & $\mathrm{Nd}$ \\
\hline Tracajá & $\mathrm{TF}$ & $\begin{array}{l}\text { Quente e } \\
\text { chuvoso }\end{array}$ & $\begin{array}{l}\text { Floresta } \\
\text { densa }\end{array}$ & Baixo & Baixo & Preta & $\begin{array}{l}\text { Baixíssi } \\
\text { mo }\end{array}$ & Médio & $\mathrm{Nd}$ \\
\hline Uaicurapá & $\mathrm{TF}$ & $\begin{array}{l}\text { Quente e } \\
\text { chuvoso }\end{array}$ & $\begin{array}{l}\text { Floresta } \\
\text { densa }\end{array}$ & Baixo & Baixo & Preta & $\begin{array}{l}\text { Baixíssi } \\
\text { mo }\end{array}$ & Médio & TI \\
\hline
\end{tabular}

Legendas: V (várzea); TF (terra firme); APA (Área de Proteção Ambiental); TI (Terra Indígena); Nd (Nenhuma). Fonte: organizado pelo autor; Divisão Regional do Plano Diretor de Parintins (2006) 


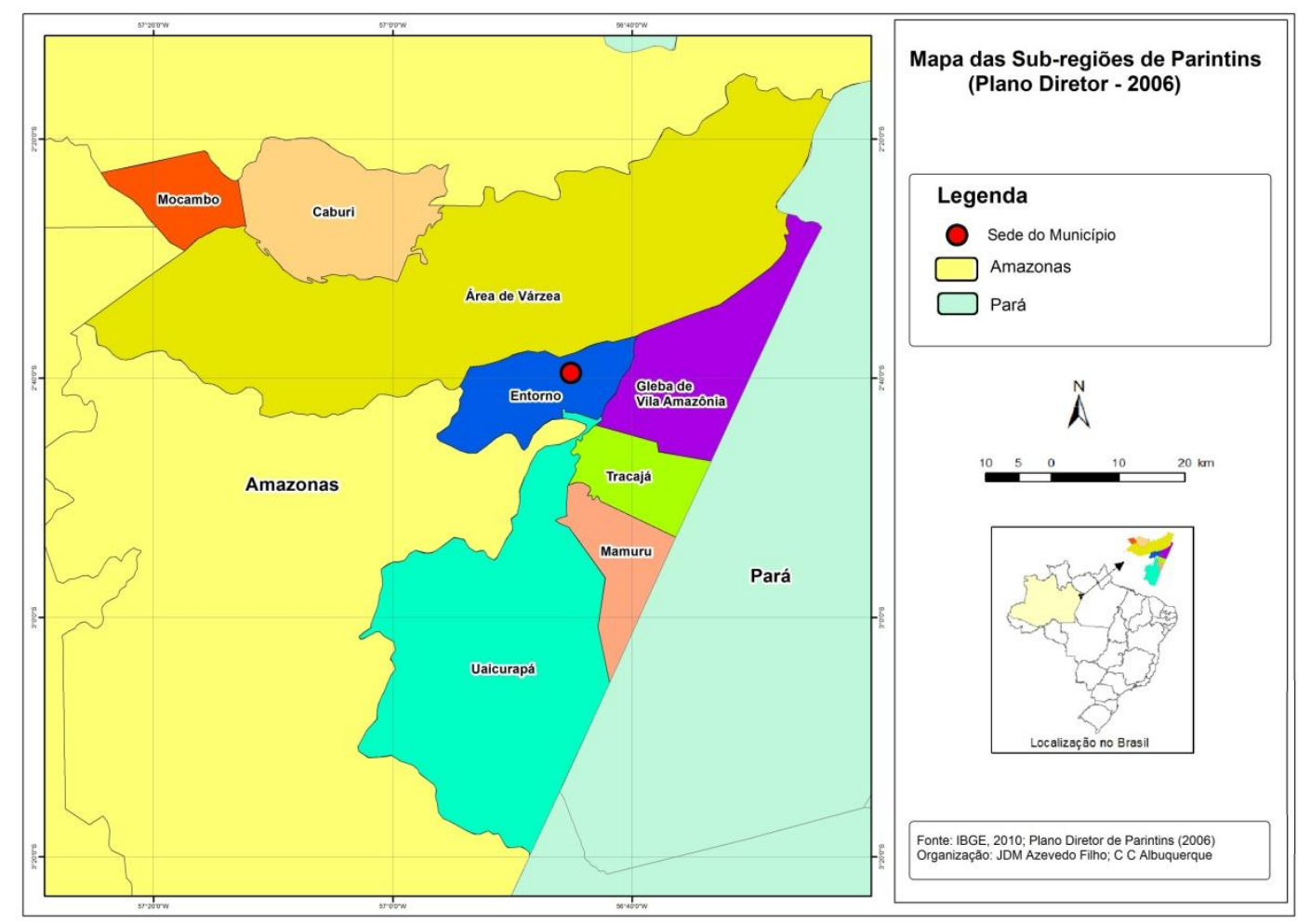

Mapa 12 - Divisão Regional de Parintins segundo o Plano Diretor, 2006

No quadro, verifica-se que a maioria das regiões está localizada em terra firme. Com efeito, sabemos que cerca de $70 \%$ das terras do município são dessa formação. O clima da região definido genericamente como quente e chuvoso é empregado para todas as regiões, pois nos faltam mecanismos técnicos para uma definição mais precisa.

O tipo de vegetação retrata, também de forma genérica, a rica diversidade florística da região. As áreas de floresta densa são encontradas em região de terra firme, porém é comum encontrar áreas de floresta rasa, denominada campinarana, comumente encontrada onde há a presença de solos arenosos, drenados a bastante drenados. Enquanto que nas áreas de várzeas encontramos, além das matas pioneiras, densa ou pouco densa, grandes áreas de campos de várzea, que se formam nos períodos de vazante. Em ambas as formações é possível encontrar áreas bastante alteradas, seja pela presença de cultivos ou pelo desmatamento para plantação de capim para o gado.

A densidade populacional foi calculada de acordo com os dados do Censo de 2010 do IBGE. A área aproximada de cada região foi calculada de acordo com a área definida no 
Plano Diretor. Apesar de abarcar 42\% da área do município, a região de Várzea é a que possui a menor densidade $\left(1,8 \mathrm{hab} / \mathrm{km}^{2}\right)$. A região do Uaicurapá, ao sul do município, também tem pouca densidade apesar de ocupar $24,6 \%$ do município. Como se sabe, a concentração populacional se faz na sede do município e seu entorno, com cerca de $67 \%$ da população vivendo na área urbana e peri-urbana. A sub-região do Caburi possui a maior densidade das áreas rurais, com 24,5 hab/km² (Quadro 5).

Quadro 5 - Parintins: população, área e densidade demográfica por Sub-regiões (2010)

\begin{tabular}{|c|c|c|c|}
\hline SUB REGIÃO & População & $\begin{array}{l}\text { Área } \\
\left(\mathbf{k m}^{2}\right)\end{array}$ & $\begin{array}{l}\text { Densidade } \\
\left(\mathbf{h a b} / \mathbf{k m}^{2}\right)\end{array}$ \\
\hline Entorno $^{5}$ & 67.438 & 303,2 & 222,4 \\
\hline $\begin{array}{c}\text { Gleba de Vila } \\
\text { Amazônia }\end{array}$ & 11.136 & 500,6 & 22,2 \\
\hline Área de várzea & 4.517 & $2.494,9$ & 1,8 \\
\hline Mocambo & 3.478 & 522,5 & 6,7 \\
\hline Caburi & 5.106 & 208,0 & 24,5 \\
\hline Mamuru & 2.497 & 233,6 & 10,7 \\
\hline Tracajá & 2.865 & 221,8 & 12,9 \\
\hline Uaicurapá & 4.255 & $1.468,0$ & 2,9 \\
\hline
\end{tabular}

Fonte: IBGE, 2011.

Organizado pelo autor.

A construção de um mapa ambiental e do turismo é ainda mais complicada. Tomamos, novamente, os ensinamentos do Martinelli (2001), nos quais coloca que a metodologia mais adequada para uma cartografia ambiental é a partir de um raciocínio de síntese.

Para o autor, a Cartografia Ambiental como um setor específico da Cartografia Temática, tem que se defrontar com a realidade, articulando as diversas e, muitas vezes, divergentes maneiras de ver dos vários ramos científicos, cada um induzindo a uma representação cartográfica específica, envolvendo uma escala espaço-temporal adequada.

Dessa forma, é necessário conceber uma cartografia que articule esses diferentes níveis de análise, considerando tanto as ordens de grandeza em que os fenômenos se

\footnotetext{
${ }^{5}$ No Plano Diretor da Cidade (2006), o Entorno refere-se a cidade de Parintins e áreas próximas.
} 
manifestam quanto as combinações e contradições que acontecem entre conjuntos espaciais definidos pelos fenômenos sob apreciação, num mesmo nível espaço-temporal.

A ampliação do tempo livre, característica marcante dos tempos atuais, resultado das conquistas trabalhistas e da melhoria da qualidade de vida de vários povos, agora incorporado ao sistema capitalista para criar novas necessidades, as do lazer, forjando uma nova demanda turística em busca do exótico e de ambientes naturais.

Tal relação, motivada por essa demanda, converge para um imaginário em que a natureza é o objeto de contemplação e a produção de novos espaços turísticos.

Contudo, a exploração dessa diversidade natural dos ecossistemas e da multiplicidade cultural das sociedades que constituem um enorme potencial de recursos para a implementação das atividades turísticas, muitas vezes, não leva em consideração sua fragilidade, tanto ambiental como social.

Nessa direção, Martinelli coloca o ecoturismo como uma forma de se fazer turismo de forma consciente, caracterizado pelo acesso às áreas protegidas, patrimônios, não só da natureza, mas também da cultura e da história, com o objetivo específico de contemplar o conteúdo de sua paisagem, bem como de estudá-la, engendrando um consumo produtivo do espaço, mediante sua consciente apreensão e respeito.

Poucos autores tem trabalhado uma cartografia do turismo sem se referir a uma imagem do espaço para que o turista saiba encontrar o que deseja, cuja função básica seja a de registro e orientação de itinerários, um mapa para atender interesses comerciais. Martinelli, em um artigo de trata da cartografia do turismo e o imaginário (2001) destaca que nesse sentido, a paisagem passa a ter um destaque no mundo das imagens do turismo,

Torna-se um recurso. É vendida com forte dose de fantasia. Negocia-se o verde da floresta, o cume das montanhas, o pôr do sol dourado, a praia ensolarada com o mar azul engastado por coqueiros. Esse imaginário, quanto mais distante de nós, mais exótico se torna. Exerce maior encanto, mistério e estímulo. Cada cultura, no entanto, enaltece seu arquétipo (p. 161). 
Mas a proposta aqui apresentada é uma Cartografia do meio ambiente com ênfase no turismo, considerando que na Amazônia, de modo geral, essa atividade tem forte ligação com a natureza. Tanto é assim, que Martinelli destaca o ecoturismo como o turismo adequado nessas condições.

Como já foi colocado, nessa perspectiva nos direcionaremos a uma cartografia de síntese, como propõe Martinelli. Isso nos leva a uma cartografia que representa conjuntos espaciais que são agrupamento de lugares caracterizados por agrupamentos de atributos. Contemplando a inter-relação com o turismo ou o ecoturismo, esse agrupamento deve representar unidades de paisagem dotadas de potencial turístico (MARTINELLI, 2001).

O resultado contido no mapa de síntese, busca representar a expressão da realidade concreta, contida nas unidades propostas. De certa forma, nelas estão contidas as diversas características espaciais do município, como os aspectos naturais, vegetação, hidrografia, clima e também sociais reportados aqui e acolá, direta ou indiretamente, contidos nos dados oficiais ou de conhecimento empírico, resultado da nossa experiência e vivência na área de estudo.

O quadro 6, a seguir, sintetiza as características comuns e aspectos naturais e culturais e a intensidade do turismo para, depois, conceber um mapa de síntese.

Quadro 6 - Quadro síntese dos agrupamentos dos lugares - Parintins

\begin{tabular}{|c|c|c|c|c|c|c|c|}
\hline $\begin{array}{l}\text { Agrupamentos/ } \\
\text { lugares }\end{array}$ & $\begin{array}{l}\text { Área - } \\
\text { km² }^{2}\end{array}$ & $\begin{array}{l}\text { Popula } \\
\text { ção }\end{array}$ & $\begin{array}{l}\text { Dens. } \\
\text { Demog. } \\
\text { Hab/km² }\end{array}$ & $\begin{array}{l}\text { Várzea } \\
\text { (V) ou } \\
\text { Terra } \\
\text { firme } \\
\text { (TF) }\end{array}$ & $\begin{array}{l}\text { Aproveitamento } \\
\text { Econômico }\end{array}$ & $\begin{array}{l}\text { Fragilidade } \\
\text { Ambiental }\end{array}$ & Potencial Turístico \\
\hline $\begin{array}{l}\text { - Natureza bastante } \\
\text { degradada com } \\
\text { turismo modesto. } \\
\text { Vila Amazônia e } \\
\text { entorno }\end{array}$ & 308,9 & 8.812 & 28,53 & $\mathrm{TF}$ & $\begin{array}{l}\text { Produção } \\
\text { agrícola/pecuária; } \\
\text { Piscicultura; } \\
\text { Extrativismo }\end{array}$ & $\begin{array}{l}\text { Ravinas } \\
\text { voçorocas; } \\
\text { Solo arenoso; } \\
\text { desmatamento e } \\
\text { queimadas. }\end{array}$ & $\begin{array}{l}\text { Sítios arqueológicos; } \\
\text { monumentos } \\
\text { históricos e culturais } \\
\text { (japoneses); áreas de } \\
\text { lazer; turismo rural }\end{array}$ \\
\hline $\begin{array}{l}\text { - Natureza com } \\
\text { avançado processo de } \\
\text { degradação; turismo } \\
\text { em expansão. } \\
\text { Região da Valéria e } \\
\text { Paraná de Parintins }\end{array}$ & 145,2 & 2.527 & 17,40 & TF e V & $\begin{array}{l}\text { Produção } \\
\text { agrícola/pecuária; } \\
\text { Piscicultura; } \\
\text { Pesca } \\
\text { subsistência; de } \\
\text { extrativismo; } \\
\text { criação de abelhas }\end{array}$ & $\begin{array}{l}\text { Enchente; } \\
\text { vazante; queda de } \\
\text { barranco; } \\
\text { pisoteamento do } \\
\text { solo por bovinos e } \\
\text { bubalinos. }\end{array}$ & $\begin{array}{l}\text { Beleza cênica; } \\
\text { Ecoturismo; turismo } \\
\text { rural; pesca esportiva. } \\
\text { Parada de cruzeiros. }\end{array}$ \\
\hline
\end{tabular}




\begin{tabular}{|c|c|c|c|c|c|c|c|}
\hline \multicolumn{8}{|l|}{ Continuação } \\
\hline $\begin{array}{l}\text { Natureza com } \\
\text { moderado processo de } \\
\text { degradação e turismo } \\
\text { fraco. } \\
\text { Bacia do Uaicurapá }\end{array}$ & 1996,6 & 9.617 & 4,82 & $\mathrm{TF}$ & $\begin{array}{l}\text { Produção } \\
\text { agrícola/pecuária; } \\
\text { Piscicultura; } \\
\text { extrativismo }\end{array}$ & $\begin{array}{l}\text { Enchente; } \\
\text { vazante; } \\
\text { desmatamento de } \\
\text { APPs; } \\
\text { desmoronamento } \\
\text { de encosta; } \\
\text { pisoteamento do } \\
\text { solo por bovinos; } \\
\text { infestação de } \\
\text { insetos (pium) }\end{array}$ & $\begin{array}{l}\text { Beleza cênica; praia } \\
\text { fluvial; Ecoturismo; } \\
\text { turismo rural. }\end{array}$ \\
\hline $\begin{array}{l}\text { - Área protegida, } \\
\text { natureza impactada, } \\
\text { turismo fraco. } \\
\text { APA Nhamundá e } \\
\text { entorno }\end{array}$ & 1443 & 2.780 & 1,93 & $\mathrm{~V}$ & $\begin{array}{l}\text { Produção } \\
\text { agrícola/pecuária; } \\
\text { pesca de } \\
\text { subsistência; } \\
\text { pesca comercial; }\end{array}$ & $\begin{array}{ll}\text { Pisoteamento } & \text { do } \\
\text { solo por bovinos e } \\
\text { bubalinos; } & \\
\text { desmatamento; } & \\
\text { exploração } & \text { de } \\
\text { lagos } & \text { de } \\
\text { reprodução } & \text { de } \\
\text { peixes; queda } & \text { de } \\
\text { barranco } & \\
\end{array}$ & $\begin{array}{lr}\text { Beleza cênica; UC de } \\
\text { uso sustentável; } \\
\text { turismo rural; } & \text { turismo } \\
\text { ecológico } & \text { e } \\
\text { ecoturismo; pesca } \\
\text { esportiva; } \\
\text { fluvial }\end{array}$ \\
\hline 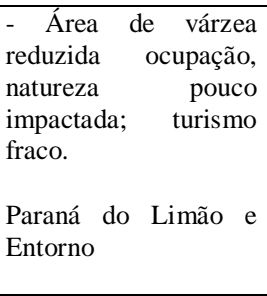 & 984,3 & 1.534 & 1,56 & V & $\begin{array}{l}\text { Produção } \\
\text { agrícola/pecuária; } \\
\text { produção -de } \\
\text { hortaliças; pesca } \\
\text { de subsistência; } \\
\text { pesca comercial; }\end{array}$ & $\begin{array}{ll}\text { Pisoteamento } & \text { do } \\
\text { solo por bovinos e } \\
\text { bubalinos; } & \\
\text { desmatamento; } & \\
\text { exploração } & \text { de } \\
\text { lagos } & \text { de } \\
\text { reprodução } & \text { de } \\
\text { peixes; queda } & \text { de } \\
\text { barranco } & \\
\end{array}$ & $\begin{array}{lr}\text { Beleza } & \text { cênica; } \\
\text { turismo rural; } & \text { turismo } \\
\text { ecológico } & \mathrm{e} \\
\text { ecoturismo; } & \text { pesca } \\
\text { esportiva; } & \text { passeio } \\
\text { fluvial } & \end{array}$ \\
\hline $\begin{array}{l}\text { - Área urbanizada; } \\
\text { natureza com forte } \\
\text { antropização; turismo } \\
\text { em franco } \\
\text { desenvolvimento. } \\
\text { Parintins e entorno }\end{array}$ & 310 & 67.438 & 217,54 & $\mathrm{~V}$ e TF & $\begin{array}{l}\text { Comércio e } \\
\text { Serviços urbanos; } \\
\text { produção agrícola } \\
\text { de subsistência } \\
\text { (hortifrutigranjeir } \\
\text { o); indústrias; } \\
\text { pecuária leiteira; } \\
\text { piscicultura }\end{array}$ & $\begin{array}{l}\text { Poluição urbana; } \\
\text { RSU sem destino } \\
\text { adequado (lixão a } \\
\text { céu aberto); falta } \\
\text { de arborização }\end{array}$ & $\begin{array}{l}\text { Festival Folclórico; } \\
\text { Festa Religiosa (NS do } \\
\text { Carmo) ; Carnaval de } \\
\text { rua; Turismo urbano ; } \\
\text { sitio histórico urbano; } \\
\text { monumentos urbanos } \\
\text { de relevância; } \\
\text { infraestrutura urbana e } \\
\text { turística; passeio } \\
\text { fluvial; parada de } \\
\text { cruzeiros. }\end{array}$ \\
\hline $\begin{array}{l}\text { - Área em processo de } \\
\text { urbanização; natureza } \\
\text { com pouco impacto; } \\
\text { turismo fraco e } \\
\text { sazonal. } \\
\text { Mocambo e Caburi }\end{array}$ & 770,2 & 8584 & 11,15 & $\mathrm{TF}$ & $\begin{array}{l}\text { Produção } \\
\text { agrícola/pecuária; } \\
\text { hortaliças; } \\
\text { Extrativismo } \\
\text { Comércio e } \\
\text { Serviços urbanos; } \\
\text { pecuária leiteira; }\end{array}$ & $\begin{array}{l}\text { Vazante } \\
\text { (dificuldade de } \\
\text { acesso); } \\
\text { desmatamento de } \\
\text { APPs; } \\
\text { desmoronamento } \\
\text { de encosta; } \\
\text { pisoteamento do } \\
\text { solo por bovinos }\end{array}$ & $\begin{array}{l}\text { Beleza cênica; praia } \\
\text { fluvial; Ecoturismo; } \\
\text { turismo rural; Festival } \\
\text { folclórico; Festival de } \\
\text { Verão; passeio fluvial. }\end{array}$ \\
\hline
\end{tabular}

Baseado nisso, podemos propor esse agrupamento espacial para Parintins considerando seu potencial ambiental e turístico (mapa 12):

1. Natureza bastante degradada com turismo modesto (Vila Amazônia e seu entorno):

Essa área é caracterizada pela presença de uma forte concentração populacional na agrovila e de produção agrícola na área de assentamento. A agrovila é lembrada pela presença histórica da ocupação japonesa entre as décadas de 1920 e 1940, guardando ainda hoje alguns poucos prédios daquela época. Possui uma estrada de 
chão batido ligando as diversas comunidades e assentamentos, bem como a outras comunidades do estado do Pará, no município de Juruti. Possui praticamente toda sua área em terra firme, cortada por igarapés e por possuir alguns lagos.

2. Área urbanizada; natureza com forte antropização; turismo em franco desenvolvimento (Parintins e seu entorno):

A cidade de Parintins comporta basicamente todo o serviço e infraestrutura disponível no município. Aeroporto, bancos, escolas, centros médicos e todos os mais importantes serviços estão localizados na sua sede. Na sede também é realizado o Festival Folclórico de Parintins e todas as atividades culturais e artísticas dos bois- bumbás Garantido e Caprichoso. É ainda importante destacar o Carnailha, carnaval de rua da cidade e a Festa religiosa de Nossa Senhora do Carmo, no mês de julho.

3. Natureza com avançado processo de degradação e turismo em expansão (Região da Valéria e Paraná de Parintins):

Lugar de visitação de navios transatlânticos. A região possui grande beleza cênica caracterizada pelo contraste entre as terras baixas de várzea e as formações onduladas e elevadas da terra firme, que dão origem às serras, ali encontradas. A presença de sítios arqueológicos também chama a atenção, principalmente na comunidade de Santa Rita. O Paraná de Parintins guarda as características próprias do modo de vida em área sujeitas às alagações. O artesanato e a pesca são as atividades importantes e em períodos diferentes.

4. Natureza com moderado processo de degradação e turismo fraco (Bacia do Uaicurapá):

Compreende uma vasta área ao sul do município e de sua sede. Formada basicamente pelo rio Uaicurapá e seus afluentes de águas pretas. Caracterizado pela presença de praias fluviais durante o período de vazante dos rios. Durante esse período é realizado o festival de Verão do Uaicurapá (setembro). Comunidades indígenas habitam o extremo sul da área.

5. Área protegida, natureza impactada, turismo fraco (APA Nhamundá e entorno): Como em todas as áreas protegidas existem restrições ao seu uso. Todavia, ainda não existe um Plano gestor da referida área, o que possibilita a ocupação desordenada, inclusive para criação de bovinos e bubalinos que causam severos impactos já comprovados. Possui um complexo de lagos, furos e paranás propícios à pesca esportiva e passeios fluviais de observação de flora e fauna. 
6. Área de várzea com reduzida ocupação, natureza pouco impactada; turismo fraco (Paraná do Limão e entorno)

O Paraná do Limão é um importante divisor do território municipal. Localizado totalmente na várzea é ocupado por famílias que aprenderam a lidar com a produção de hortaliças na várzea, em canteiros suspensos, por causa dos períodos de enchente. Possui, também, grande quantidade de lagos, furos e outros paranás, propícios para a pesca esportiva e passeios fluviais para observação da flora e da fauna.

7. Área em processo de urbanização; natureza com pouco impacto; turismo fraco e sazonal (Mocambo e Caburi):

As duas agrovilas formam o distrito de Mocambo. Estão assentadas em áreas de terra firme. Suas sedes têm características de cidades pequenas. São realizados festivais folclóricos, festas religiosas, festival de verão e de pesca do peixe liso. Seus principais visitantes são os moradores de Parintins e comunidades próximas. 


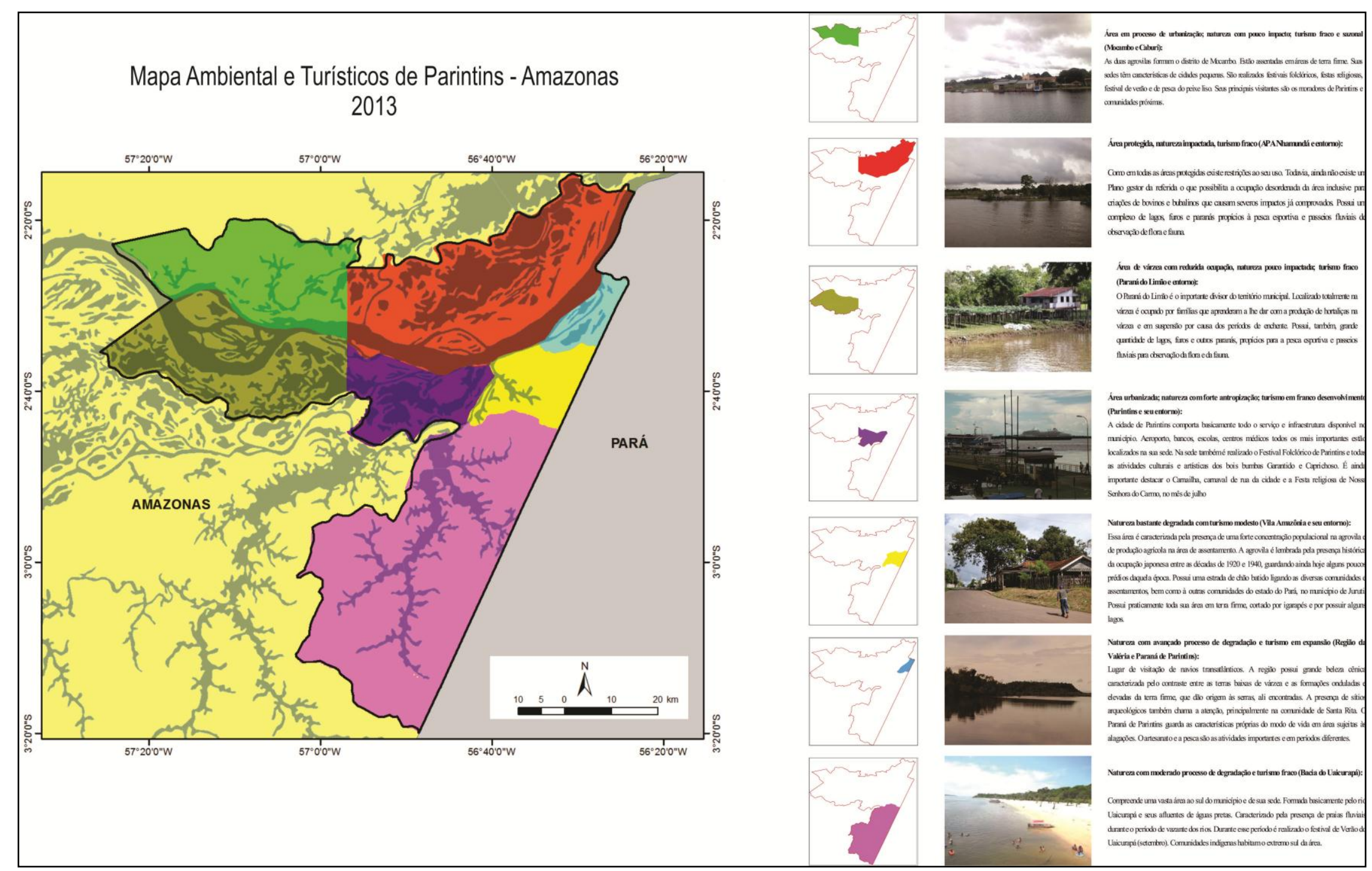

Mapa 13 - Ambiente e turismo em Parintins - Amazonas 


\section{CAPÍtULO V}

\section{O TURISMO NA REGIÃO DA VALÉRIA: CAMINHOS PARA UM TURISMO DE BASE COMUNITÁRIA}

O Turismo de Base Comunitária é um conceito novo, mas que tem sido utilizado como referência para um turismo envolvendo a inserção das comunidades no turismo. Para Bartollo Jr e colaboradores (2009), entende-se por turismo comunitário qualquer forma de organização empresarial baseada na propriedade e na autogestão sustentável dos recursos patrimoniais comunitários, envolvendo as práticas de cooperação e equidade no trabalho e distribuição dos benefícios resultantes da prestação de serviços turísticos.

Para esses autores o que diferencia o turismo comunitário dos demais "é sua dimensão humana e cultural, vale dizer, antropológica" (BARTOLLO JR et al, 2009, p.31) e tem como objetivo o incentivo ao diálogo entre os membros da comunidade e encontros interculturais de qualidade com os viajantes - turistas, buscando uma inter-relação entre os interlocutores, conhecendo e aprendendo com sua diversidade.

É nesse sentido que Bartollo Jr et al (2009) defendem o conceito de turismo alternativo de base comunitária como uma tentativa de se contrapor ao turismo massificado, pois esse tipo de turismo requer "menor densidade de infraestrutura e serviços, buscando valorizar uma vinculação situada nos ambientes naturais e na cultura de cada lugar" (p.86). Segundo eles, o turismo alternativo de base comunitária é uma nova forma de pensar a visita e hospitalidade, "diferenciado em relação ao turismo massificado, ainda que por ventura se dirija a um mesmo destino" (Idem, p. 86).

Nas comunidades da Valéria, o desenvolvimento de um turismo de base comunitário ainda não foi discutido profundamente, persistindo um distanciamento entre as comunidades envolvidas e os interesses pessoais e de grupos. A existência de conflitos diversos podem ser notados no acompanhamento das diversas atividades de preparação e realização do receptivo turistico. Todavia, já existe a iniciativa de alguns grupos, organizados em associação, de 
tentar discutir, principalmente com as universidades e o poder público, iniciativas que caminhem para um turismo mais organizado e em base comunitária.

\subsection{As Comunidades da Região da Valeria}

A região da Valéria compreende várias comunidades localizadas na parte mais a leste do município. O Plano Diretor do Município (2006) define essa área corresponde à sub-região de Vila Amazônia que compreende toda a área dentro do Projeto de Assentamento de Vila Amazônia, de responsabilidade do Instituto Nacional de Colonização e Reforma Agrária (INCRA).

A área delimitada neste estudo corresponde ao espaço definido no mapa ambiental e turístico, tratado capitulo IV, como "Natureza com avançado processo de degradação e turismo em expansão", correspondente à Região da Valéria e Paraná de Parintins. Essa área é constituída por 9 comunidades. Conforme os resultados do Censo de 2010 a população dessa região é de 2.527 habitantes em 509 domicílios. A maior comunidade é a Santa Rita de Cássia da Valéria com $30 \%$ da população total, seguido da Comunidade de São Paulo e Bete Semes.

Tabela 5 - Comunidades da Região da Valéria e Paraná de Parintins Estimativa de População e porcentagem - 2012

\begin{tabular}{|l|c|c|}
\hline Comunidade & População & \% \\
\hline Bete Semes & 197 & 13 \\
\hline Betel & 159 & 11 \\
\hline Samaria & 98 & 7 \\
\hline Santa Rita de Cássia & 447 & 30 \\
\hline São Paulo & 201 & 13 \\
\hline Menino Deus & 124 & 8 \\
\hline Nossa Senhora do P Socorro & 135 & 9 \\
\hline Santa Maria do Murituba & 82 & 5 \\
\hline Ssma Trindade do Laguinho & 60 & 4 \\
\hline Total & 1.503 & 100 \\
\hline
\end{tabular}


5.1.1 Comunidade de várzea do Paraná de Parintins

As Comunidades de Menino Deus e Nossa Senhora do Perpetuo Socorro, no Paraná de Parintins, estão totalmente localizadas em região de várzea (Mapa 13).

Albuquerque (2012) em estudo na região indica que a principal atividade produtiva dessa zona é a agropecuária extensiva de bovinos, seguida pela agricultura de ciclos rápidos, com destaque para mandioca, melancia, milho e hortaliças; a produção de mel em 23 propriedades e a pesca.

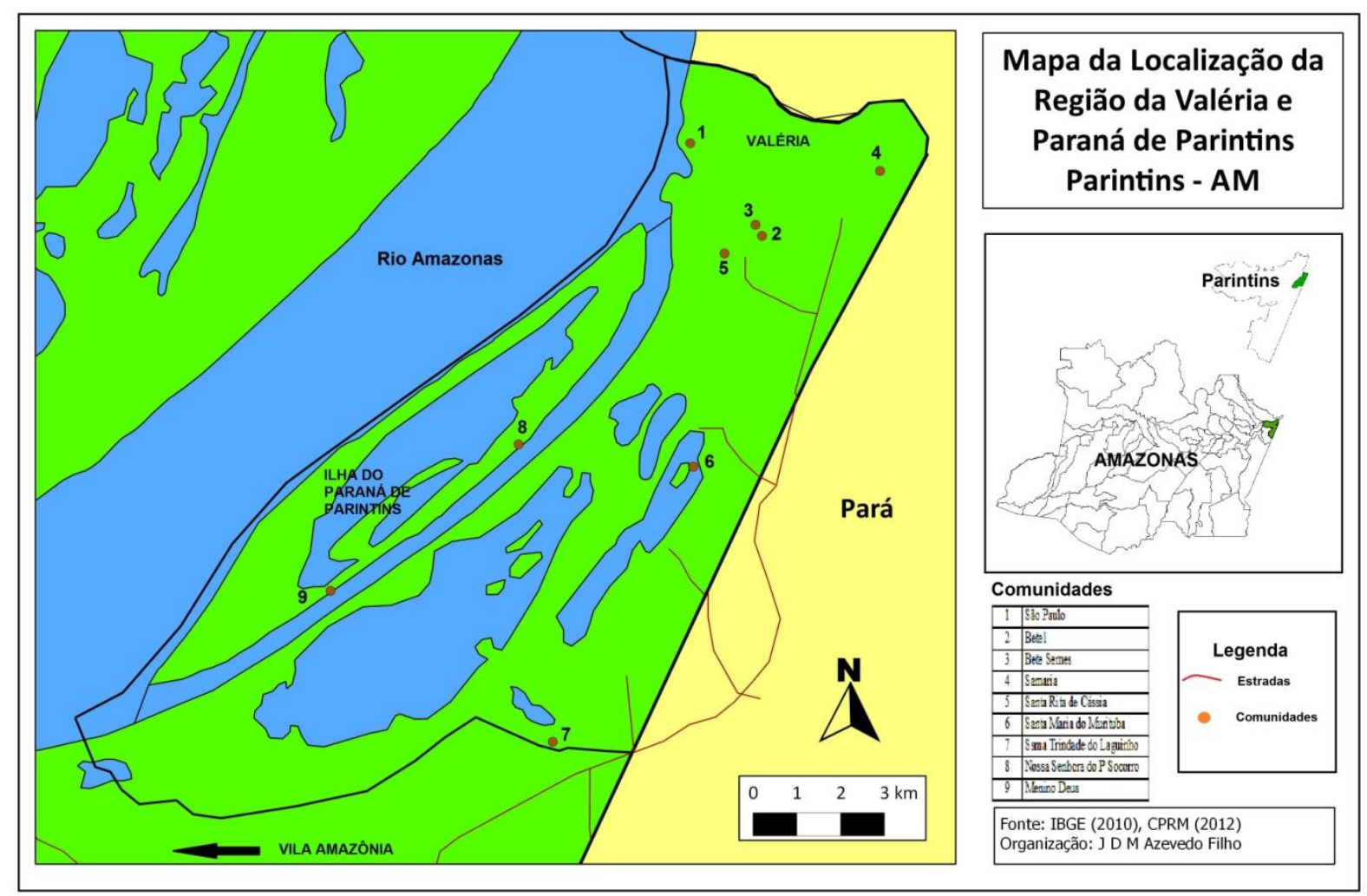

Mapa 14 - Localização da Região da Valéria e Paraná de Parintins

Essas atividades se instalaram em detrimento da cobertura vegetal, provocando desequilíbrio que exigiram ações e mudança por parte dos comunitários e do poder público para conservação e recuperação do ambiente. Ações como a criação de uma ONG denominada Grupo Ambiental Natureza Viva (GRANAV), instituição composta de agentes ambientais voluntários formados pelos moradores. A transformação da área em projeto de 
assentamento extrativista pelo governo federal contribuiu para reduzir os impactos ambientais na área (ALBUQUERQUE, 2012).

A pesca constitui uma atividade tradicional dessa zona, sendo predominantemente exercida no rio Amazonas e no Paraná. Essas áreas estão no acordo de pesca elaborado pelas comunidades. Contudo tem-se registrado uma diminuição na produção, em decorrência da pesca predatória feita por barcos regionais de porte médio do Pará e Amazonas na forma de "arrastão" com redes de grande dimensão, falta de controle da pesca pelos órgãos governamentais. Segundo Albuquerque (2012), os principais problemas ambientais relacionam-se principalmente à pesca predatória, ao desmatamento nas margens dos rios, paraná, lagos e furos; lixo despejado nas margens do Paraná e rio Amazonas, esgotamento sanitário feito de forma precária no sistema de fossa negra, que durante o período de cheia fica submerso ou diretamente no Paraná e a prática da pecuária bovina extensiva nas áreas de sedimentação nas margens dos lagos.

Albuquerque (2012) propõe um zoneamento ambiental da área em estudo, correspondente a área de várzea. Pelo zoneamento proposto a área seria delimitada em zona de preservação, zonas de uso restrito comunitário, destinado ás atividades dos comunitários, incluindo os lagos de pesca; zona de preservação integral ambiental, para proteção da ictiofauna e área sensíveis de várzea (APP) e uma zona de uso produtivo e de difícil controle, como o grande rio Amazonas e o paraná de Parintins.

A experiência do turismo no paraná de Parintins está ligado a visitas que os turistas de cruzeiros fazem à área vindos da Boca da Valéria. Em tempos recente, passado, eram comuns visitas de pesquisadores que vinham verificar as atividades desenvolvidas pelo Projeto.

\subsubsection{A "Boca da Valéria” um novo espaço turístico}

"Boca da Valéria" é o termo turístico utilizado para denominar o espaço visitado pelos turistas que viajam em cruzeiros pelo rio Amazonas. O termo boca é usado regionalmente para designar a entrada de um determinado rio ou paraná. Nesse sentido, o termo sempre foi usado para designar a entrada da região pelo lago da Valéria, na parte mais oriental do município de Parintins. 
A apropriação do nome parece ser uma estratégia de marketing para vender, turisticamente falando, esse espaço.

Na boca da Valéria está localizada a Comunidade de São Paulo. Na historiografia do lugar, essa região sempre foi citada pelos primeiros viajantes devido à presença da serra de Parintins que marca os limites territoriais entre o Amazonas e o Pará. Em 1806, a região foi o local escolhido para um posto de fiscalização de mercadorias que eram transportadas de barco em direção ao Grão-Pará. O posto funcionou até 1824 (SAUNIER, 2003).

Mapa 15 - Mapa da Região da Valéria - "Boca da Valéria"

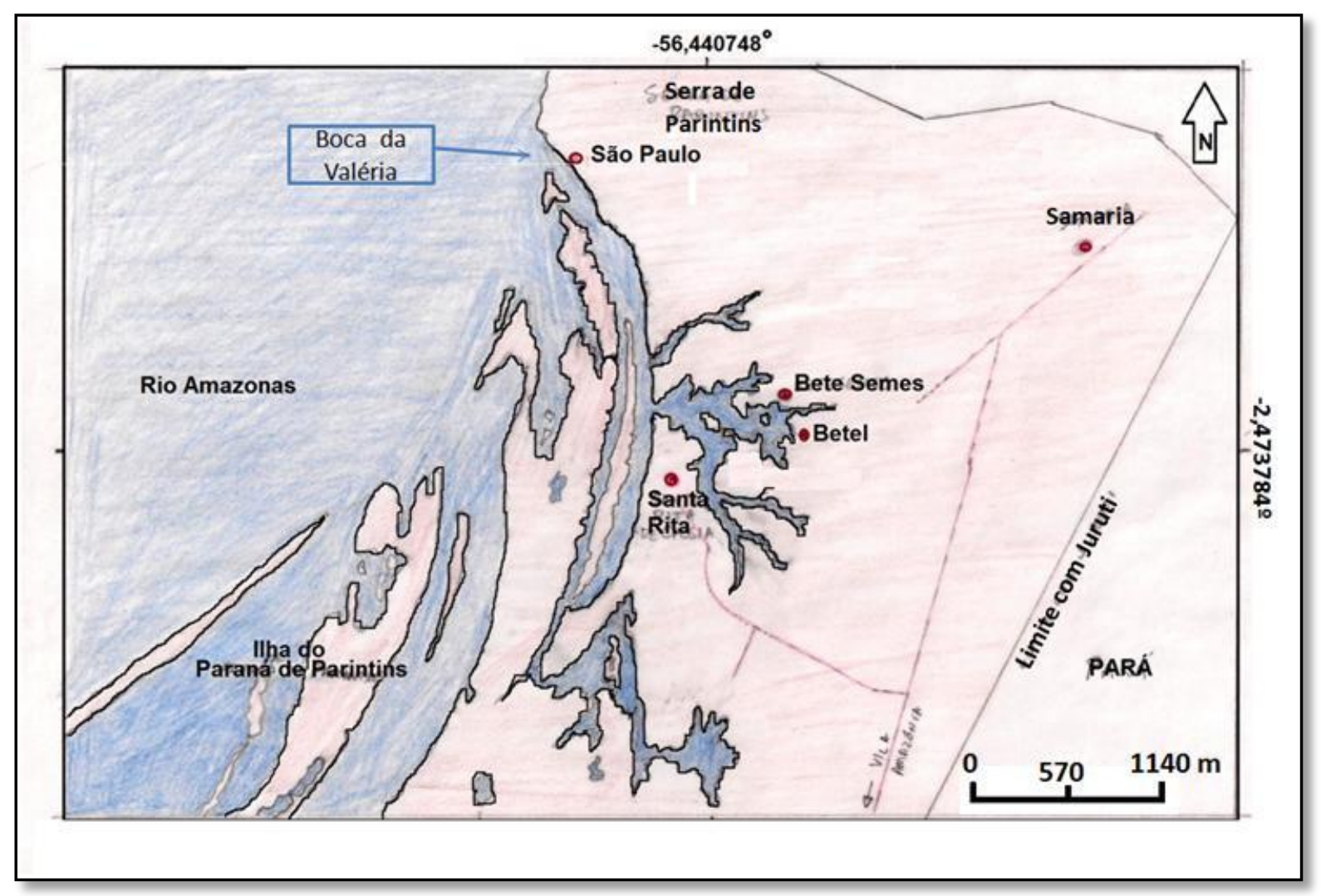

Fonte: Organizado por JD Azevedo Filho, a partir de imagem do Google Earth

Contam os antigos moradores, que nos anos 1970, devido à visitação dos primeiros transatlânticos, alguns moradores da Comunidade de Santa Rita de Cássia mudaram-se para a boca da Valéria, dando origem à Comunidade de São Paulo.

A região da Valéria é composta por 5 comunidades (mapa 14). A maior delas é a Comunidade de Santa Rita com 68 famílias e uma escola municipal com 6 salas de aula. É 
ligada por estrada à Vila Amazônia que dispõe de serviço de transporte até Parintins por meio de balsa tipo ferryboat.

Além da floresta, a região é formada pelos Lagos Murituba, Lago Grande e Lago Pequeno, sendo uma região famosa pelos sítios arqueológicos nela localizados e suas serras (morros) (figura 25).

A região da Valéria é uma área de terras altas correspondentes a formações dissecadas da formação Alter do Chão, com altitudes que podem chegar a 100 metros. A Serra de Parintins é o maior exemplo, com 115 metros.

Figura 25 - Transatlântico em frente da serra de Parintins na "Boca da Valéria" Parintins-AM

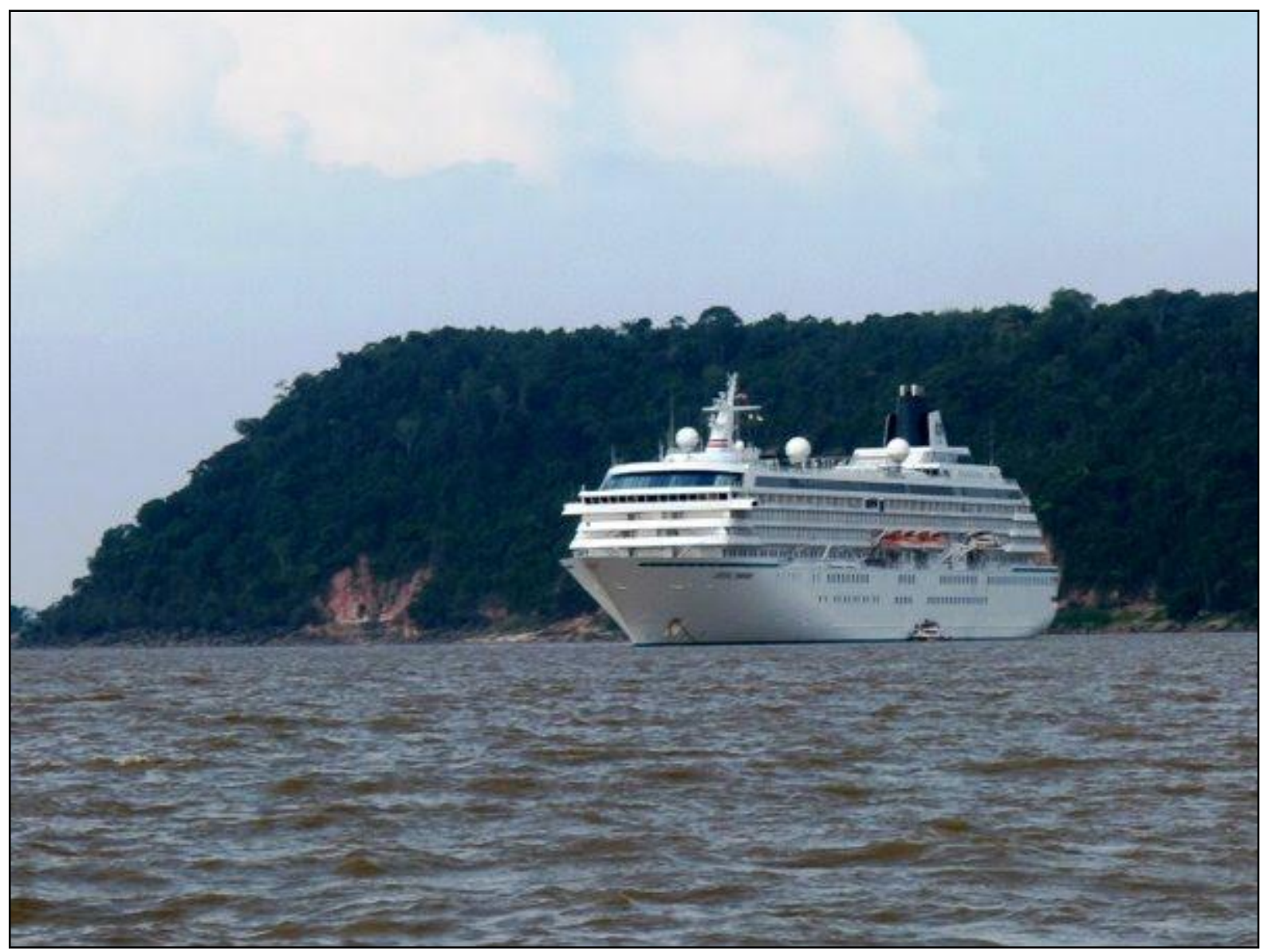

Fonte: arquivo J. D. M. Azevedo Filho 
As características da região não diferem do restante do município. A população afirma, no entanto, que as temperaturas são amenizadas pelos ventos que sopram no local e devido à presença da vegetação. Afirmam também que é uma região que chove muito.

Segundo dados climáticos as temperaturas médias da região atingem $26{ }^{\circ} \mathrm{C}$ e as chuvas chegam a 2200 a $2300 \mathrm{~mm}$ (CPRM, 2010)

As atividades econômicas desenvolvidas em toda a região da Vila Amazônia estão voltadas principalmente a agricultura. Sendo praticado também a pecuária e a pesca.

Na região da Valéria, o turismo tem crescido principalmente pela visita no período de outubro a abril dos cruzeiros de transatlânticos que param em frente a serra de Parintins, tendo como ponto de desembarque a Comunidade de São Paulo.

As comunidades visitadas são as Comunidades de São Paulo, Betessemes, Betel e Santa Rita de Cássia e Menino Deus do Paraná de Parintins.

\subsubsection{Comunidade de Santa Rita de Cássia}

A comunidade de Santa Rita de Cássia é a maior de todas na localidade. São 68 domicílios e 438 habitantes, conforme o $\operatorname{IBGE(2011).~Está~basicamente~assentada~no~topo~de~}$ um platô de $82 \mathrm{~m}$ de altura. Chega-se a Santa Rita de barco ou por estrada de chão batido (piçarra) que leva até a Vila Amazônia.

A origem da comunidade remonta os anos 1920. Todavia há resquícios arqueológicos da ocupação por vários povos na localidade em vários períodos.

Pesquisas realizadas pela Universidade do Estado do Amazonas (SILVA, SOUZA e FONSECA, 2010) sobre a presença dos artefatos arqueológicos na Comunidade de Santa Rita apontam algumas respostas para o processo de ocupação da região e a produção cerâmica.

De acordo com Neves (2006), dados sobre o início da produção cerâmica na Amazônia mostram que as datas mais antigas estão em torno de 5.000 e 3.500 a. C., bem antes da adoção da agricultura. As cerâmicas mais antigas das Américas estão localizadas no Baixo Amazonas, próximo à Santarém. No Baixo Amazonas há um trecho que vai do rio Trombetas e Amapá à leste, até a região das cidades de Nhamundá, Parintins e Maués no Amazonas, a oeste, onde é possível encontrar sítios com cerâmicas de grande beleza pertencentes à chamada tradição Incisa e Ponteada, datados do ano 
1.000.a.C a 1.500 d.C., ou seja, até o início da colonização europeia. Eles podem ser bastante grandes, com vários hectares de área e terras pretas antrópicas, indicando que eram grandes aldeias sedentárias ocupadas por populações numerosas. Neves (2006) salienta que talvez as cerâmicas mais conhecidas dessa tradição sejam as cerâmicas tapajônicas ou de Santarém (p.81).

Os autores procuram aproximar ainda mais as características cerâmicas com as das encontradas na região.

Outras cerâmicas que pertencem à tradição Incisa e Ponteada foram identificadas próximo à Santarém, na região dos rios Nhamundá e Trombetas, assim como na região de Parintins, e são conhecidas como Kondori. Essas cerâmicas apresentam uma decoração modeladas em motivos antropomórficos e zoomórficos. A diferença das cerâmicas tapajônicas é que os vasos são geralmente maiores. Os fragmentos desses vasos são denominados pelos moradores locais como "caretas" e frequentemente encontradas em áreas de terra preta e roças por toda a região do Baixo Amazonas (SILVA, SOUZA e FONSECA, 2010, p. 81).

Segundo os autores, não se pode afirmar, dados os níveis de conhecimento até agora adquirido, quais os povos que ocuparam a região e deixaram os vestígios. Apontam poder tratar-se dos tupinambá que se casaram e aparentaram-se com os índios Aratu, Apoicuitara, Godui, Yara e Curiatós que habitaram a margem esquerda do rio Amazonas (SILVA, SOUZA e FONSECA, 2010, p. 81-82).

Segundo relatos dos moradores mais antigos a vila se formou aos poucos depois de uma grande seca.

“- eu tinha, eu nem me lembro mais, quando eu vim pra cá meu filho mais velho tinha 3 meses, hoje ele tem 41 [em 1972]. Não morava muita gente por aqui. Nós viemos pra cá mesmo, mas a gente ia lá pra Colônia [Assentamento] fazer roça. A gente ia morar prá lá com os moradores de lá. O lugar lá era chamado naquele tempo Miritizal seco. (...) $O$ pessoal convidava, vamo fazer doce, vamo fazer roçado. Quando fica secando o roçado, vocês vem imbora. A gente queima e a gente manda chamar vocês. Ai já fica difícil a gente ficar vindo e voltando. E ai a gente fez roçado, o pessoal chamou a gente pra fazer farinha. $O$ marido foi buscar uma ceivadeira* grande que a gente tinha (...) e um catitu* [*equipamentos pra fazer farinha] ele foi também buscar. A gente fazia farinha lá. Ai a gente num voltou mais, o meu marido vendeu tudo lá... Fiquemo...e ai a gente fez uma barraquinha 
aqui, a gente vinha fim de semana assistir a missa aqui, já tinha a igreja aqui. Já tinha umas pessoas aqui, acho que já tinha bem umas 30 famílias aqui sim. Só que aumentou muito, tinha muitos filhos e foi crescendo, se espalhando”, conta dona RX, 70 anos, aposentada.

Hoje a comunidade atende os moradores do entorno como sua pequena infraestrutura. A escola Municipal recebe inclusive alunos das comunidades próximos do vizinho estado do Pará. No entanto, carece de um posto de saúde, todo o atendimento é realizado na Vila Amazônia, cerca de 20 km por estrada de chão batido.

A atividade principal é a agricultura e a pecuária. Todavia, como em todas as comunidades da região, alguns se especializaram na confecção de artesanato dirigida aos turistas de cruzeiros.

Segundo PR, 40 anos, são cerca de 400 artesão que obtém uma renda extra complentar à atividade de agricultor ou criador. Segundo ele “ - a safra de turistas aqui na Valéria ela tem uma demanda muito grande de material de fabricação[artesanato], é uma economia que fica na região, bem grande, por exemplo nos temos aqui na Valéria mais de 400 artesões, então esses artesões na safra, em media, eles conseguem fazer 50 mil dólares por cada artesão, cada um em toda safra né [de outubro a abril], então é uma economia muito grande. O pessoal até de Parintins, quando o pessoal comenta isso, por ai era tudo isso?. Mas se você for conferir que um artesão por safra, por encosta do transatlântico, cada artesão ele consegue fazer 300 dólares só os artesãos que tem material pra vender, fora os caras que vão nas trilhas [guias], que tem o rabeta [passeio de canoa], sabe que ali a pessoa que tá vendendo o colar, tem um animal que eles simpatizam, a pessoa sempre leva pra li algum papagaio ${ }^{6}$, essas coisas ai, então é uma economia muito grande que fica na região da Valéria, a partir de setembro a maio de todos os anos [é possível que a estação se prolongue de setembro a maio]".

Apesar de haver um erro de cálculo do entrevistado, quando ele afirma que os artesãos chegam a ganhar 50 mil dólares, que, na verdade, considerando que ganham por parada de navio 300 dólares e são entre 10 e 15 paradas de navios, é provável que ganhem entre 3.000 e 4.500 dólares por estação de cruzeiros, é significativa a importância dessa renda extra para as famílias das comunidades envolvidas com o receptivo turístico.

${ }^{6} \mathrm{O}$ entrevistado cita a presença de animais durante as visitas dos turistas, o que pode ser caracterizado como ato ilegal de venda de animais silvestre, mas foi observado que eles levam alguns animais "domesticados" para exposição e registro fotográfico, o que dá renda aos seus donos. Apesar disso, o ato pode ser considerado incorreto, à vista da lei. 
Figura 26 - Santa Rita de Cássia da Valéria: estrada, comunidade, escola e acesso por rio

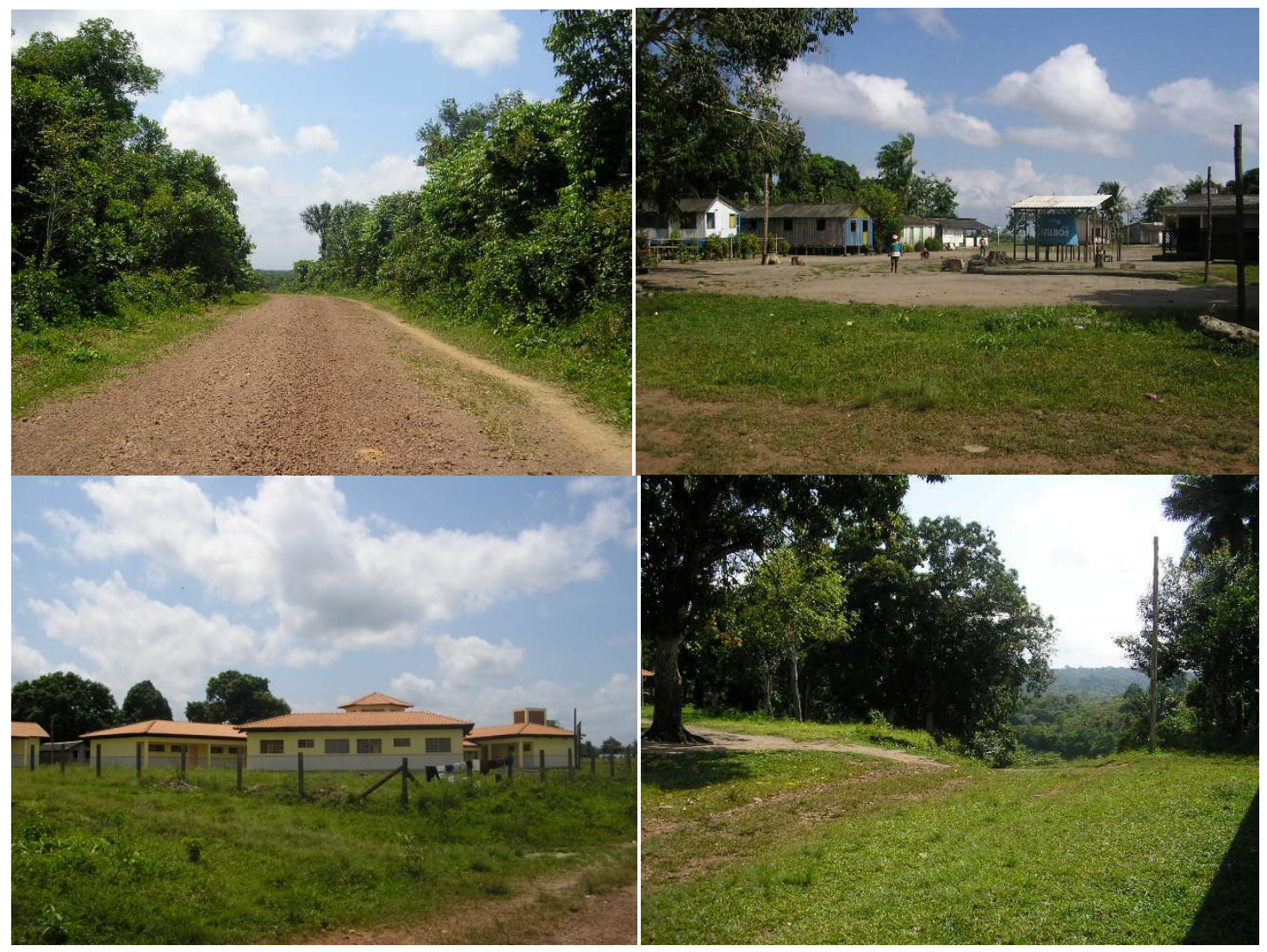

Fonte: Acervo do autor

No entanto, os artesãos afirmam que nem sempre as vendas são boas. Quando começaram a exigir que a madeira fosse certificada, muitos navios começaram a avisar seus passageiros sobre a dificuldade de transportar material não certificado, além de uma melhor consciência ecológica por parte dos turistas que se viam na obrigação de recusar qualquer produto feito a partir de exploração ilegal, animais silvestres ou por serviço de menor ou escravo. Ainda perdura esse cuidado, necessitando que haja um dialogo entre os artesãos, órgãos ambientas e agentes de viagem.

Os primeiros turistas visitavam a região no período da cheia dos rios, adentrando a região com seus próprios barcos. A comunidade de Santa Rita, que fica mais para dentro, era a mais visitada, pois de suas encostas era possível ver o rio Amazonas e parte do complexo de lagos e floresta. Além do mais chamava a atenção a quantidade de artefato cerâmico que aflorava do chão que os habitantes locais não davam muita importância. Até que pedaços cerâmicos começaram a ser vendidos com suvenir ao turista por até um dólar, ou trocado por bolachas, chocolate, brinquedos com as crianças. 
Quem afirma isso é dona RX, “- olhe esse navios começaram a chegar aqui quando nós já morava aqui. Eles num encostava assim na bera eles ficava rodando. Olha, quando nós morava lá no Miritizal seco, os meninos vinha estuda aqui, eles [os barcos dos turistas] encostava lá, eles davam ovo cozido, eles davam espelho, eles davam pente .. agradavam... e outras coisa eles botavam nas mãos deles. Olha, quando eles chegavam lá no centro com nós eles chegavam muito alegre, olha nós ganhamo isso, o motorista deu isso pra nós, ele me deu pente, ele me deu lápis, me deu ovo cozido, me deu pão”...chegavam muito alegre”.

Posteriormente, por iniciativa de um historiador que ocupou a coordenação do CAT, no final dos anos 1990, houve uma maior atuação da Amazonastur na região, oferecendo curso e palestras. Nesse momento, com ajuda de antropólogos convidados pela referida agência, foi colocada a importância do artefato como bem cultural, histórico e de patrimônio da União, sendo ilegal a sua comercialização. As "caretinhas", como são chamadas por apresentarem características amorfas semelhantes a animais e rostos, deixaram de ser vendidas, chegando, inclusive a terem a iniciativa de criar um museu desses objetos. O lugar escolhido foi um antigo escritório do INCRA abandonado e durou pouco tempo.

Figura 27 - Artefatos cerâmicos de Santa Rita da Valéria exposta em local improvisado
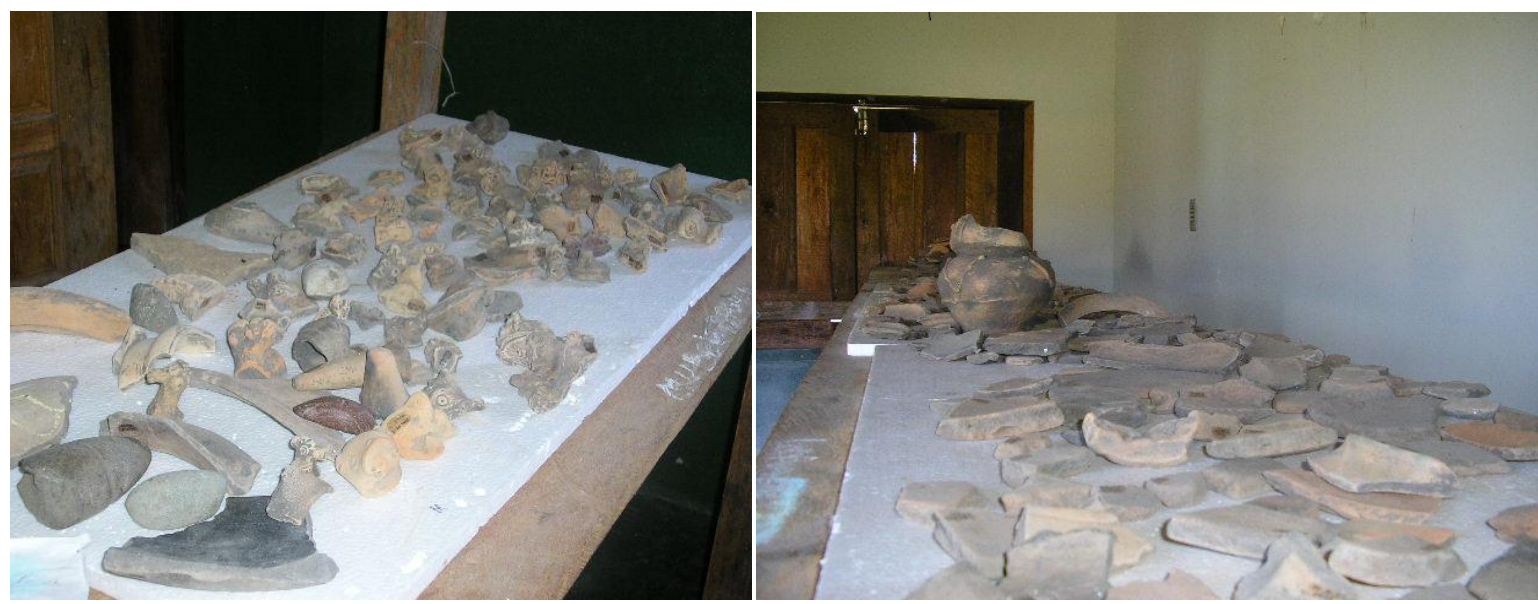

Fonte: Acervo do autor

5.1.4 Comunidade de São Paulo da Valéria

A Comunidade de São Paulo é composta por cerca de 20 famílias, com uma população aproximada de 200 pessoas (2012). Está localizada no sopé da serra de Parintins, 
na boca da Valéria. São os primeiros a ter contato com os turistas visitantes. É em São Paulo que outros membros se reúnem para preparar o receptivo como capinar, limpar, armar ou reparar o porto improvisado de madeira onde as lanchas vão aportar, além de definir os lugares de cada um e suas barracas.

Os primeiros turistas que chegam pelo mês de outubro experimentam o período da vazante dos rios da Amazônia, basicamente, até dezembro é quase impossível fazer passeio de canoa.

A Comunidade de São Pedro restringe-se a uma pequena extensão de terras, aproximadamente 100 metros, caracterizando uma ocupação desordenada e fora da área de assentamento do PA de Vila Amazônia. Apesar de que o INCRA já fez o assentamento desses nos seus pequenos lotes. Isso tem causado alguns conflitos com os proprietários de terras assentados mais antigos e com lotes maiores que se estendem até o local.

Figura 28 - Comunidade de São Paulo: receptivo na vazante e na cheia
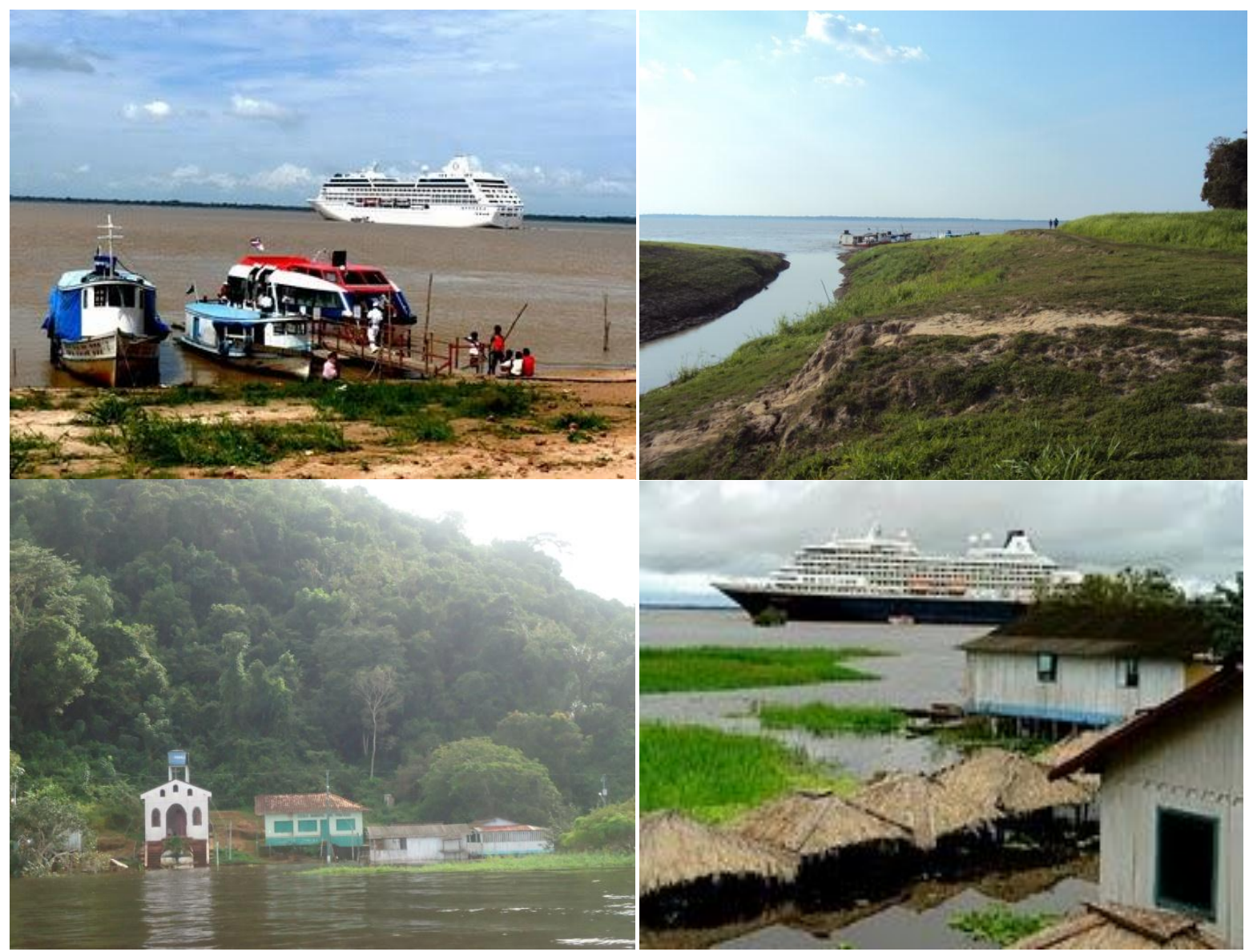

Fonte: Acervo do autor 
Dona VR, 50 anos, agricultora e artesã de São Paulo conta da dificuldade de preparar a área para o receptivo e os conflitos: "não essa parte ai é frente do (fulano)... a comunidade é pequena, é 100 metros só, só um pedacinho... só 100 metros de frente a comunidade... essa parte todinha é deles... da AC [assentada] né... é eles que organizam essas barraquinhas ai [construídas para o receptivo e alugadas]... porque se fosse pertencer pra comunidade, era nós que organizava, mas só que ... ai fica difícil de organizar... essa parte de lá da comunidade... que tem o marco pra cá é meu, é meu terreno, mas só que essa parte pra cá os turistas já tão acostumados e vão só pra estrada e pro lado de lá, pra cá bem pouco eles anda... ai fica difícil organizar pra cá, talvez se organizasse era capaz de virem turistas pra cá pra esse lado também, mas que fica difícil fica, porque eles tão acostumados mais em ir pra estrada, e ai pra banda da escola da Samaria... ai fica difícil de organizar nesse sentido, porque se fosse assim pertencesse tudo pra comunidade ficava mais fácil de organizar melhor esse problema ai".

Os conflitos não se resumem somente a essa questão. Tem crescido o número de canoeiros para passeios nos lagos, ocasionando conflitos e ciumeiras. Os mais antigos reclamam que os novatos não respeitam os preços estabelecidos e a competitividade causa conflitos.

“- o cara consegue 50 dólares num rabeta, ali fazendo catraia (passeio), uma catraia essas coisas ai é dinheiro", afirma PR, da comunidade de Santa Rita.

O preço estabelecido fica entre 5 e 10 dólares por pessoa dependendo do tempo do passeio, a média é 1hora. Alguns canoeiros dizem que cobram mais caro pelo peso, pois os turistas tendem a ser pesados.

“- mas nós cobra assim, se for um grandão não dá prá levar muita gente e então é mais caro, eles pagam... sabem que é pesado", afirma NO, 25 anos, da Comunidade Betel.

A Comunidade também começou a surgir depois das visitas dos transatlânticos. As poucas famílias que moravam na região não ocupavam onde é hoje São Paulo. Logo algumas famílias se deslocaram de Santa Rita para a boca da Valéria, formando a Comunidade de São Paulo. A igreja foi construída com ajuda financeira dos transatlânticos.

Dona VR faz referência aos primeiros transatlânticos a parar na "Boca da Valéria" e das estratégias para tornar a região ponto de recepção de turistas: “- eles começaram a vir, no tempo do seu Rosset [provavelmente um guia ou o oficial de cabotagem brasileiro] uns 30 anos que ele veio ,(...) ele parou ai perguntou como ele podia ajudar a comunidade, e era a 
primeira vez que ele tava vindo, ai a gente conversou com ele nessa época, não era ainda comunidade, era um núcleo... ele era brasileiro,(...) o núcleo ainda pertencia a Santa Rita, mas a gente já tinha um culto, mas era mais pra lá, Santa Rita era a principal comunidade, ai foi o tempo que eles desembarcaram. Ele pediu pra ajudarem assim, ai ele pediu que a gente fizesse uma urna, essa urna foi feita pra angariar recursos pra fazer a igreja, foi feita uma igreja de madeira, e depois de madeira já ficou sendo de alvenaria e assim que começou, e ai começou os navios né, ai depois desse navio já vieram muitos navios que todos paravam aqui”.

\subsubsection{As comunidades evangélicas de Bete Semes e Betel}

As comunidades de Bete Semes e Betel são duas comunidades separadas por um pequeno riacho bem no centro da área dos lagos, é um lugar de belas paisagens. Sua característica principal, e que as diferencia das demais, é que são comunidades que se formaram em torno de uma igreja evangélica, na realidade duas. A Comunidade Betel tem 20 famílias e Bete Semes em torno de 50. Como em outras comunidades a maioria se dedica a agricultura e a pesca, tendo o artesanato como uma alternativa de renda. Praticamente todas as famílias dessas comunidades têm um artesão ou canoeiro, ou ambos, para atender o turismo. As duas comunidades são muito visitadas, pois as rotas dos passeios de canoas dirigem-se ao logo da Valéria, em frente as comunidades (ver mapa 15).

Figura 29 - Comunidades de Bete Semes e Betel durante a vazante

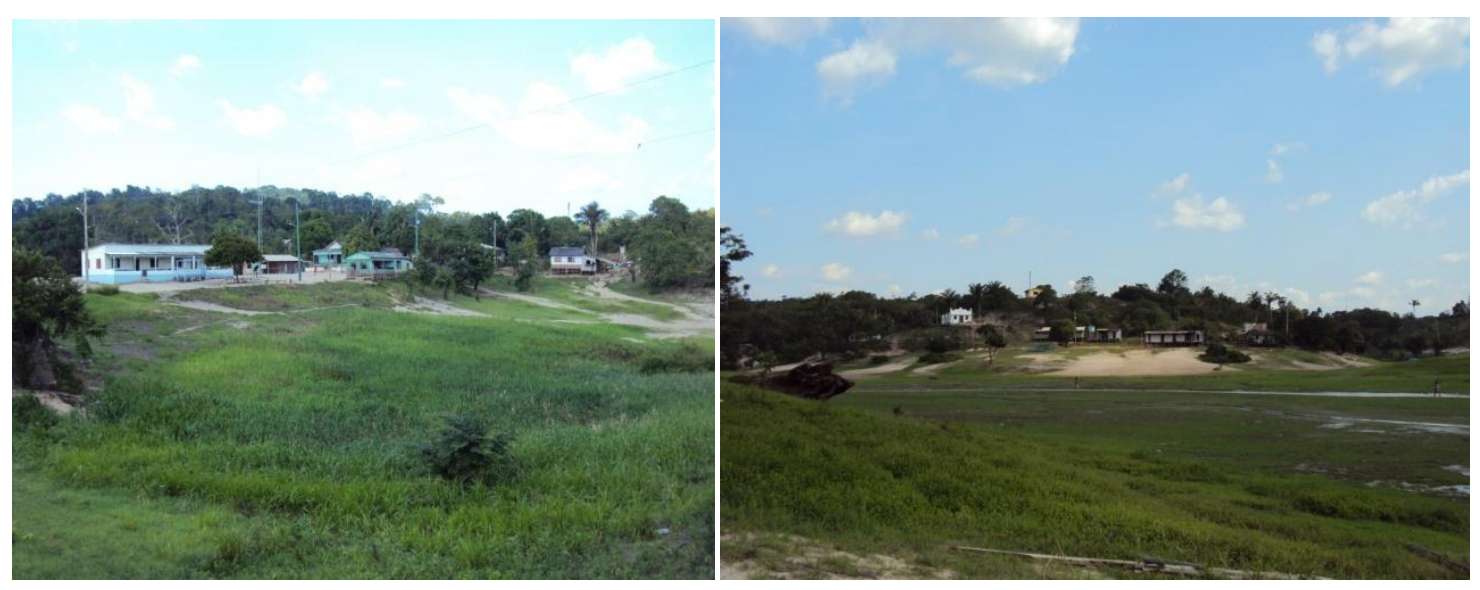

Fonte: Acervo do autor 
Todas as comunidades têm em comum a participação apenas sazonal com o turismo, deixando outra parte do seu tempo para as atividades com a agricultura, a pesca e o trato com a casa e o terreno. As Comunidades, como foi visto, não têm apoio do Estado para essa prática, sendo insignificante o apoio aos artesãos e outros envolvidos com o turismo, ao longo do tempo.

Mapa 16 - Desenho de mapa mental da Região da Valéria, tendo ao centro a Comunidade de Santa Rita.

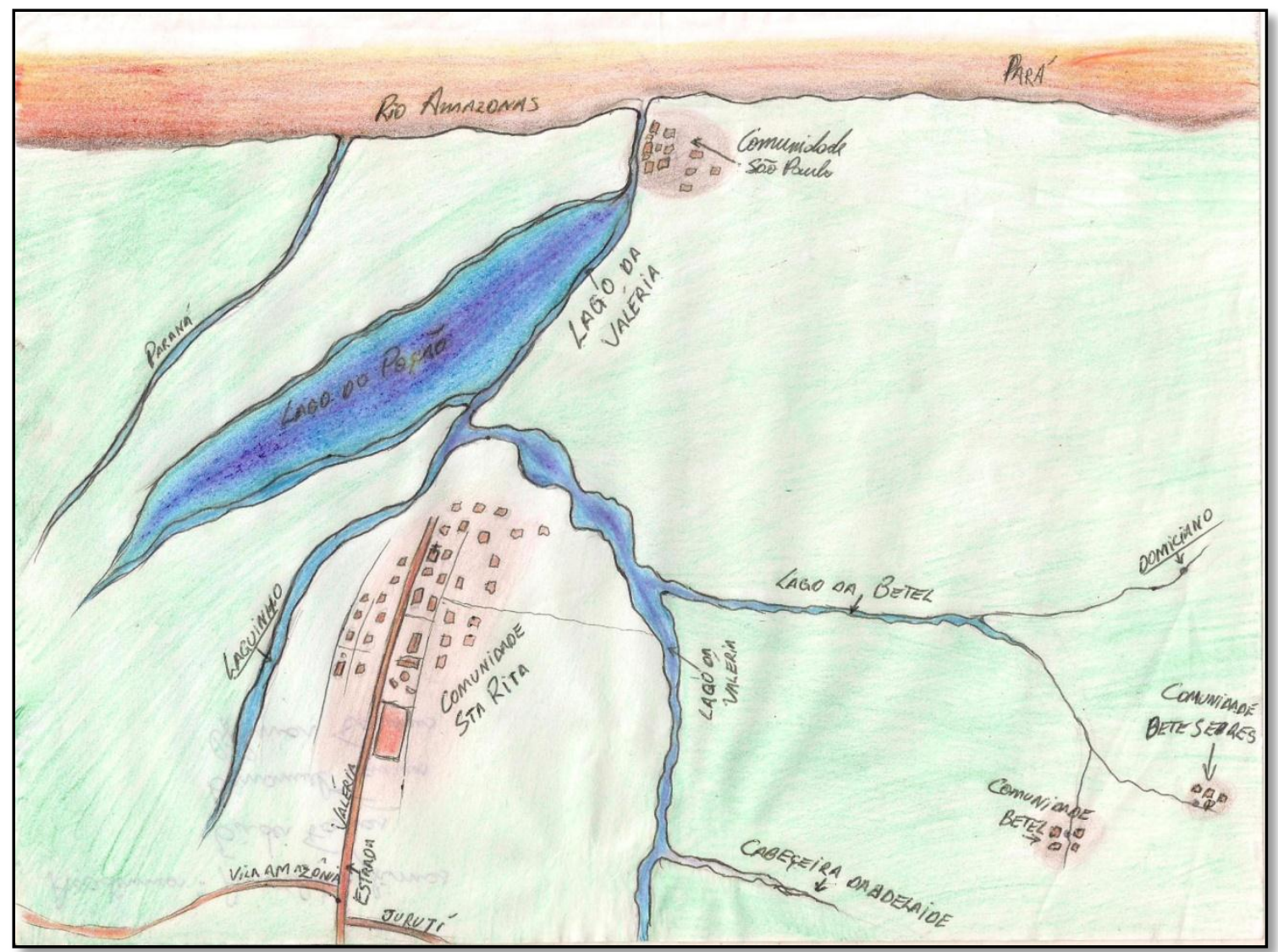

Fonte: elaborado pelos comunitários de Santa Rita

Os artesãos sempre reivindicam uma maior participação do poder público principalmente na realização de cursos e aperfeiçoamento profissional, curso de línguas estrangeiras também são solicitados para os mais novos. 
Os comunitários conhecem bem a região, como pode ser observado no mapa desenhados por moradores de Santa Rita (Mapa 15). Isso por si já indica que há muitas possibilidades de aproveitamento dos jovens como guias turísticos, por exemplo.

O mapa apresenta detalhes da região e suas comunidades, colocando a comunidade de Santa Rita, como o centro de toda a área. Talvez por sua posição, em cima de um platô, ou por sua importância como maior comunidade e que apresenta uma melhor infraestrutura. 


\section{CONCLUSÃO}

Nestes novos tempos, descritos como um período de paz mundial, as melhorias nas condições de renda dos trabalhadores via aumento do número de empregos e o aumento do tempo-livre, possibilitou um investimento maior do capital no setor de turismo, situação que já vinha se desenhando desde o fim da Segunda Grande Guerra, principalmente nos países desenvolvidos e que agora atinge um número maior da população mundial. Nem mesmo as crises econômicas, a partir dos anos 1980, e os atentados de 11 de setembro de 2001 e suas consequências, conseguiram reduzir o crescimento do setor que nos últimos anos apresenta crescimento ascendente.

Novas formas de turismo surgiram e outras cresceram, sempre em busca do diferente, do exótico, fora do cotidiano. As discussões em torno das questões ambientais também elevaram o nível de conscientização pela proteção do planeta e dos seus ecossistemas, valorizando ainda mais esses nichos de turismo e possibilitando um aporte maior de capital no setor. O que era novo deixou de ter importância e a busca por novidades é cada vez maior. O que pode ser novo nesses tempos de informação em tempo real?

Se vendem os espaços como se vende uma mercadoria, já disse Carlos (1996). Mas essa forma de reprodução do capital não é nova. Há muito, se vendem as grandes cidades, os grandes monumentos, os grandes centros comerciais, as grandes paisagens como mercadoria a ser consumida pelo mercado turístico.

A imagem que o turista tem dos lugares na Amazônia não é a mesma, pois se difere dentro do tempo e do espaço. Ao longo do tempo, nos deparamos com diversos conceitos ou pré-conceitos atribuídos e aplicados a Amazônia e seus diversos espaços. Isso implica também reconhecer que a Amazônia não é homogênea, nem física nem socialmente. Seus diversos ecossistemas envolvem uma multiplicidade de interações e inter-relações já bastante estudadas. Seus habitantes diferem justamente porque se adaptam e interagem com o meio em que vivem, modificam-no e encontram sempre novas formas de sobrevivência na floresta.

Existem formas de exploração da floresta muito degradantes e que acabam atingindo a Amazônia, se considerada como uma reserva de recursos. A exploração mineral e madeireira, sem dúvidas, é uma das principais causas de degradação ambiental, e porque não dizer, social, na região. O garimpo, apesar de proibido, porque extremamente degradante, continua a ocorrer na região. 
As formas de exploração com a floresta em pé, já defendida por cientistas como Lutzsemberg, Ab’Saber e Gonçalves dentre outros é uma alternativa viável para a manutenção das populações locais, preservando o meio ambiente em que vivem. Sem falar naqueles que, inclusive, foram martirizados na luta em defesa dessas ideias como Chico Mendes, Doroty Stendy e tantos outros.

Formas sustentáveis de vida na floresta, e não necessariamente o conceito sustentável dos que não conhecem a Amazônia, podem resultar em bons frutos para as sociedades locais. Exemplos como os sistemas agroflorestais sustentáveis (SAS), reservas extrativista, praticados em várias áreas da Amazônia e no Cerrado dão conta de como é possível explorar os recursos naturais sem depredar o meio em que se vive. O turismo também se coloca como um desses exemplos, desde que desenvolvido de modo a que se preserve não só o meio, mas também as formas de vida da sociedade e suas culturas. Exemplos não faltam, apesar de serem poucos, fazendo com que se perceba a necessidade de apreender e aprofundar as experiências nesse campo.

Como exemplo de turismo de base comunitária, pode-se citar o município de Silves no Amazonas, onde uma comunidade local com o apoio de uma ONG e da Igreja Católica criou a Associação de Silves pela Preservação Ambiental e Cultural (ASPAC) que conseguiu junto à Câmara de vereadores a proibição da pesca comercial e a implantação do manejo da pesca artesanal por meio de proteção dos lagos. O programa comunitário de educação ambiental criado, denominado "caravana mergulhão", valorizou e mobilizou a participação e o debate sobre a importância do respeito às normas e legislação municipal sobre conservação da pesca. Paralelamente ao trabalho de educação ambiental e conservação dos recursos pesqueiros, a ASPAC, com apoio do WWF (World Wild Found), optou pelo desenvolvimento do turismo como alternativa econômica para as comunidades ribeirinhas. Foi construída uma Pousada (Aldeia dos Lagos) onde há participação intensa das comunidades ribeirinhas, tanto na atividade de hospedagem como nas atividades de lazer oferecidas ao turista. Os turistas conhecem como vive o ribeirinho, como ele pesca, planta, faz a farinha, faz o peixe para comer além de fazerem os passeios dentro da floresta e na cidade, deixando divisas para o município (VALENTE; AZEVEDO FILHO, 2011).

Em Parintins, o foco do turismo está direcionado ao seu Festival Folclórico que ganhou dimensões mundiais após sua midiatização nos anos 1990. Todos os esforços são realizados para tornar o "período do Boi" um forte atrativo para turistas do Brasil e do mundo. São três dias de intenso movimento, mas uma preparação que dura o ano todo e se intensifica 
nos três meses que antecedem o grande evento, realizado no último fim de semana de junho. Pode-se pensar esse tipo de turismo sob diversos ângulos, seja como uma aventura, que se define pelas dificuldades que são impostas ao turista que tem que viajar em embarcação regional, aventurando-se pelo rio Amazonas. Ao mesmo tempo, pelas dificuldades durante a estada na cidade e o caos provocado pela grande quantidade de pessoas que vem para Parintins. Em tal situação, nem mesmo toda a estrutura de serviços empregada pelo Estado é suficiente para atender a todas as demandas. Também, é possível percebê-lo como uma grande experiência cultural e de lazer, onde o diferencial é estar em contato com uma cultura diferente, com lugares diferentes e com atividades diferentes daquelas do cotidiano do visitante.

Mas, Parintins tem um grande potencial turístico, além do Festival. Existem outros eventos que dão notoriedade regional, mas que ainda são pouco explorados, como o Carnaval, a Festa da Padroeira, Nossa Senhora do Carmo e a visitação por turistas de transatlânticos. Além desses, há possibilidades de exploração da atividade turística nas comunidades rurais, dada suas características peculiares de trabalhores-ribeirinhos e produtores rurais, que interessam à uma atividade turística comunitária.

Os turistas de cruzeiros já conhecem a "Boca da Valéria", na região da Valéria, interagem com a população local, visitam a floresta e compram artesanato, mas não é uma relação de troca de conhecimentos e experiências saudável entre turistas e comunidade local. É necessário avançar nessa discussão, a fim de tornar esse tipo de turismo um exemplo para a Amazônia como um todo. Essa discussão deve abranger todas as comunidades envolvidas, os agentes de turismo e o poder público, de modo a buscar caminhos que possibilitem a convivência da população com o turista, sem que haja perda de suas características culturais tradicionais, sejam eles pescadores, agricultores ou artesãos.

Desta feita, é preciso (re) pensar o turismo para a região e em particular para o estado do Amazonas e para Parintins. O turismo tem que deixar de ser aquela atividade de momento, independente e desarticulada do todo. O todo é o cotidiano do lugar, o cotidiano da sociedade, o seu dia a dia, suas relações com o meio ambiente, suas manifestações simbólicas, culturais, religiosas, artísticas, políticas e econômicas. O turismo tem que perpassar o sentido de ser da população local, caso queira permanecer como uma atividade importante para o município (e para o Estado). É preciso repensá-lo e planejá-lo adequadamente, implicando envolver toda sociedade nisso. Esse envolvimento não pode ser mero coadjuvante e sim o ponto central da 
atividade para que os bons frutos advindos da atividade turística possam ser colhidos pelos diversos atores, inclusive pelos que são afetados diretamente pela presença dos turistas.

Por conta disso, é possível propor algumas ideias, discutidas e levantadas durante toda essa pesquisa:

I . Ao nível institucional

1. Criar a Secretaria de Turismo do município independente e com autonomia financeira;

2. Reestruturar e consolidar o Conselho Municipal de Turismo, abrindo espaço para que entidades e sociedade civil participem das discussões;

3. Elaborar o Plano Municipal de Turismo abrangendo as diversas manifestações culturais e artísticas das comunidades;

4. Criar o Centro de Atendimento ao Turismo, municipal, para atender permanentemente os visitantes do município;

5. Criar roteiros turísticos para o Festival de Parintins e para além do mesmo.

II. Ao nível das demandas apresentadas para o Festival de Parintins e outros eventos:o

1. Planejar ações educativas junto com as associações e entidades públicas de ensino para atuar antes, durante e depois do Festival, Carnailha, Festa da Padroeira, seja na área de Educação Ambiental, Sanitária, Trânsito e outras.;

2. Qualificar a mão de obra utilizada nos eventos por meio da ofertas de cursos, oficinas, palestras e seminários.

3. Rediscutir junto ao Gabinete de Gestão Integrada a verdadeira função dos agentes públicos da Segurança, da Saúde e da Guarda Civil durante os eventos, ou sua ausência;

4. Planejar melhor a ocupação do espaço público durante a realização do Festival, Carnaval e outros eventos;

5. Garantir os direitos de idosos, deficientes e estudantes no que tange ao acesso ao Bumbódromo; 
6. Propiciar às Comunidades o envolvimento nas atividades turísticas, seja enquanto produtor de bens e serviços indispensáveis aos eventos, seja como potencial ponto de visitação;

7. Qualificar, planejar, organizar as Comunidades envolvidas com o turismo, principalmente as que já recebem algum tipo de visitação como a Valéria, Mocambo, Caburi e Vila Amazônia.

Por fim, os itens apresentados acima, e outros, indicam a necessidade de se repensar o turismo em Parintins. A dinamicidade dessa atividade econômica é demonstrada pelo processo que faz com que hoje, em 2013, já tenha havido uma significativa reforma na estrutura do bumbódromo, passando a abrigar 16.500 pessoas para assistir ao espetáculo além de outras comodidades.

O turismo na região não está isolado do seu todo, ou seja, das políticas do turismo para a Amazônia e do Brasil. Mas, se consolida em várias partes do país, inclusive na região, uma maior valorização do turismo de base comunitária, que mesmo sem todo o apoio do estado consegue superar barreiras, divergências e interesses pessoais consegue constituir uma prática na qual a sociedade envolvida também é valorizada, seja na sua permanência no local, seja na sua cultura, e tendo uma renda extra para associar às demais atividades desenvolvidas tradicionalmente. 


\section{Bibliografia}

AB'SABER, Aziz N. Amazônia do discurso à práxis. 2a ed. São Paulo: EDUSP, 2004.

AB'SABER, Aziz N. Os domínios de natureza no Brasil: potencialidades paisagísticas. $5^{\mathrm{a}}$ ed.. Cotia: Ateliê, 2008. 159 p.

ALBUQUERQUE, Carlossandro Carvalho de. Análise geoecológica da paisagem de várzea na Amazônia Central: um estudo estrutural e funcional no Paraná de Parintins-AM, Ano de obtenção: 2012. Tese (Doutorado em Geografia) Departamento de Geografia, da Faculdade de Geociências, da Universidade Federal do Ceará. Ceará, 2012.

AMARAL, Rita de Cássia de Mello Peixoto. Festa à Brasileira: significados do festejar, no país que "não é serio". 1998. Tese (Doutorado em Antropologia) Departamento de Antropologia da Faculdade de Filosofia, Letras e Ciências Humanas da Universidade de São Paulo. São Paulo, 1998.

AMAZONAS. Amazonastur. Síntese dos Indicadores de turismo do Amazonas 2003-2011, Manaus, 2012. Disponível em http://amazonastur.am.gov.br.

ANDRADE, Larissa da Silva; CARNEIRO, Paulo. História e Memória Política do Município de Parintins 1977 a 1988. Parintins: Câmara Municipal de Parintins, 2012.

ANDRADE, Terence K.; TAVARES, Maria Goretti. O projeto de integração amazônica visto pela turistificação dos lugares. Revue franco-brésilienne de géographie / Revista francobrasilera de Geografia, №. 14, 2012.

AVÉ-LALLEMANT, Robert. No Rio Amazonas (1859). Tradução Eduardo de Lima Castro. Belo Horizonte: Itatiaia; São Paulo: Edusp, 1980.

AZEVEDO FILHO, João D’Anuzio M. Título: O impacto da poluição do ar sobre a incidência de doenças respiratórias na população de Manaus: o caso do bairro do Mauazinho entre 2000 - 2003. Dissertação (Mestrado). Programa de Pós-Graduação em Ciências Ambientais e Sustentabilidade da Amazônia - PPG CASA/CCA/UFAM. Manaus, 2004. 
BARTHOLO JR, Roberto; SANSOLO, Davis Gruber; BURSZTYN, Ivan (Orgs.). Turismo de Base Comunitária: diversidade de olhares e experiências brasileiras. $1^{\mathrm{a}}$. ed. Rio de Janeiro: Letra e Imagem, 2009. v. 1. 508p. Disponível em http://www.ivtrj.net/ivt/bibli/Livro\%20TBC.pdf, acesso em 10.02.2011.

BATISTA, Ieda Hortêncio. Urbanização e Ambiente: Análise dos indicadores da qualidade de vida na Cidade de Parintins (Dissertação de Mestrado em Ciências do Ambiente e Sustentabilidade na Amazônia/Universidade Federal do Amazonas). Manaus: UFAM, 2000.

BECKER, Bertha K. Amazônia. $3^{a}$ ed., São Paulo: Ática, 1994 (série Princípios).

BOHRER, Claudio Belmont de A.; GONÇALVES, Lucia Maria C. Vegetação. IN.: IBGE. Instituto Brasileiro de Geografia e Estatística. Geografia do Brasil. Região Norte. Vol. 3. Rio de Janeiro: IBGE, 1991, p. 137-168.

BRAGA, Sergio Ivan Gil. Os Bois-Bumbás de Parintins. Rio de Janeiro: Funarte: EDUA, 2002 (Tese de doutoramento apresentada ao Programa de Pós-Graduação em Antropologia Social da USP; orientadora: Prof. ${ }^{\text {a }}$ Dr $^{\mathrm{a}}$ Maria Lúcia Aparecida Montes). Publicado em Livro.

BRASIL. Ministério das Minas e Energia. DNPM. Projeto Radambrasil. Volume 10. Folha SA21. Rio de Janeiro: IBGE, 1976.

BUTEL, Irian; BUTEL, Larice; CURSINO, Jucielle. História e Memória Política do Município de Parintins 1964 a 1976. Parintins: Câmara Municipal de Parintins, 2012. Disponível no site da Câmara Municipal de Parintins: http://www.camaraparintins.am.gov.br/.

BUTEL, Larice et.al. História e Memória Política do Município de Parintins: $1^{\circ}$ legislatura de 1947 a 1941- Parintins: Câmara Municipal de Parintins, 2011. Disponível no site da Câmara Municipal de Parintins: http://www.camaraparintins.am.gov.br/.

CARLOS, Ana Fani A. O Turismo e a produção do Espaço. Revista Geografia e Ensino, Belo Horizonte-MG, v. 8, n.1, p. 47-56, 2002.

CARLOS, Ana Fani A. O turismo e a produção do não-lugar. In: YÁZIGI, Eduardo; CARlOS, Ana Fani A.; CRUZ, Rita de Cássia A. (Org). Turismo: Espaço, Paisagem e Cultura. São Paulo: Hucitec, 1999, p. 25-39. 
CARVALHO, José Alberto Lima de. Terras caídas e consequências sociais: costa do Micarauera - Paraná da Trindade, município de Itacoatiara - AM, Brasil. Dissertação de mestrado em Sociedade e Cultura na Amazônia. Universidade Federal do Amazonas UFAM. Manaus, 2006.

CASEMIRO FILHO, Francisco. Contribuição do turismo à economia brasileira. Tese (Doutorado). Escola Superior de Agricultura “Luiz de Queiroz”. Piracicaba, SP, 2002.

CASTRO, Iná Elias de. Paisagem e Turismo. De Estética, Nostalgia e Política. In: YÁZIGI, Eduardo. (Org.). Paisagem e Turismo. São Paulo: Contexto, 2002.

CORRÊA, Roberto Lobato. A Tradição geográfica. Rio de Janeiro. Bertrand Brasil, 1997.

CORRÊA, Roberto Lobato. Região e organização espacial. São Paulo: Ática, 1986. (2002)

COSTA, João Batista S.; BEMERGUY, Ruth Léa, HASUI, Yociteru et all. Neotectônica da região amazônica: aspectos tectônicos, geomorfológicos e deposicionais. Geonomos, nº4, vol.2, 1996, p. 23-44.

COSTA NOVO, Cristiane Barroncas M. O território do turismo de base comunitária na Amazônia: a experiência da pousada Aldeia dos Lagos em Silves - AM. Anais do XI Encontro Nacional de Turismo de Base Local: Turismo e Transdisciplinaridade: novos desafios. Niterói - RJ, 12 a 14 de abril de 2010. p. 1154-1172.

CPRM. Companhia de Pesquisa de Recursos Minerais. Serviço Geológico do Brasil. Geodiversidade do Estado do Amazonas. Organização: Maria Adelaide Mansini Maia \& José Luiz Marmos. Manaus, 2010 (CD-Room).

Companhia de Pesquisa de Recursos Minerais. Serviço Geológico do Brasil. Avaliação da qualidade das águas subterrâneas da cidade de Parintins. Relatório Técnico. Manaus, 2005.

CRUZ, Rita de Cássia A. Turismo, produção do espaço e desenvolvimento desigual: para pensar a realidade brasileira. In.: BARTHOLO JR, Roberto; SANSOLO, Davis Gruber; BURSZTYN, Ivan (Orgs.). Turismo de Base Comunitária: diversidade de olhares e experiências brasileiras. 1 ${ }^{a}$. ed. Rio de Janeiro: Letra e Imagem, 2009, p. 92-107. Disponível em http://www.ivt-rj.net/ivt/bibli/Livro\%20TBC.pdf, acesso em 10.02.2011. 
A geografia do turismo: de lugares a pseudo-lugares. São Paulo: Rocca, 2007.

Introdução à geografia do turismo. $2^{\mathrm{a}}$ ed. São Paulo: Rocca, 2003.

CUNHA, Hillândia B. ; PASCOALOTO, Domitila . Hidroquímica dos rios da Amazônia. Manaus: Governo do Estado do Amazonas; Secretaria de Estado da Cultura; CCPA, 2006. v. 01. 127p. Disponível em < http://www.povosdamazonia.am.gov.br/pdf/hid_qui.pdf>.

DIEGUES, Antonio Carlos S. Mito moderno da natureza intocada. $3^{\text {a }}$ ed. São Paulo: Hucitec/NAPAUB-USP, 2000.

FRAXE, Therezinha J. P. Homens anfíbios: etnografia de uma campesinato das águas. São Paulo: Annablume; Fortaleza: Governo do Estado do Ceará, 2000.

GALEANO, Eduardo. As veias abertas da América Latina. Rio de Janeiro: Paz e Terra, 1989.

GASTAL, Suzana. Turismo, imagens e imaginários. São Paulo: Aleph, 2005 (Col. ABC do turismo).

GATTO, Luiz Carlos S. Relevo. IN.: IBGE. Instituto Brasileiro de Geografia e Estatística. Geografia do Brasil. Região Norte. Vol. 3. Rio de Janeiro: IBGE, 1991, p. 47-60.

GOMES, Paulo Cesar da C. Geografia e modernidade. $4^{\mathrm{a}}$ ed. Rio de Janeiro: Bertrand Brasil, 2003.

GONÇALVES, Carlos Walter P. Amazônia, Amazônias. 2a ed. São Paulo: Contexto, 2008.

GONDIN, Neide. A invenção da Amazônia. 2a ed. Manaus: Valer, 2007.

HARVEY, David. A produção capitalista do espaço. 2a ed. São Paulo: Annablume, 2006 (Col. Geografia e Adjacências).

IBGE. Instituto Brasileiro de Geografia e Estatística. Geografia do Brasil. Região Norte. Vol. 3. Rio de Janeiro: IBGE, 1991.

—. Informações sobre as cidades. Disponível em http://www.ibge.gov.br/ cidadesat/topwindow.htm?1, em 2012. 
_. Resultados Preliminares do Censo de 2010. Disponível no site: http://www.ibge.gov.br/home/estatística/população/censo2010/resultados_preliminares / default_resultados_preliminares.shtm, a partir de 02 de junho de 2011.

INCRA. Instituto Nacional de Colonização e Reforma Agrária. Projetos de Reforma Agrária Conforme Fases de Implementação. MRA: INCRA/DT. Relatório 0227, $18 / 08 / 2011$.

JOLY, Fernando. A Cartografia. Trad. Tania Pellegrini. 19ª ed. São Paulo: Papirus, 2011.

KÄMPF, Nestor; WOODS, William; KERN, Dirse C.; CUNHA, Tony J. Classificação das Terras Pretas de Índio e Outros Solos Antrópicos. IN.: TEIXEIRA, Wenceslau G.; KERN, Dirce C.; MADARI, Beata; LIMA, Hedinaldo N.; WOODS, William (Edit. Téc.). As Terras Pretas de Índio da Amazônia: sua caracterização e uso deste conhecimento na criação de novas áreas. Manaus: Embrapa Amazônia Ocidental, 2009, p.87-102.

KNAFOU, Remy. Turismo e Território: por uma abordagem científica do turismo. In: RODRIGUES, Adyr A.B. Turismo e geografia: reflexões teóricas e enfoques regionais. $3^{\mathrm{a}}$ ed. São Paulo: Hucitec, 2001, p. 62-74.

LACOSTE, Yves. Geografia, isso serve, em primeiro lugar, pra fazer a guerra. Trad. Maria C. França. $4^{\mathrm{a}}$ ed. Campinas: Papirus, 1997.

Os objetos geográficos. Seleção de Textos. São Paulo: AGB, nº 18, 1988, p. 3-9.

LUCHIARI, Maria Tereza D.P. Turismo e meio ambiente na mitificação dos lugares. Turismo em análise. São Paulo: ECA/USP, v.1, nº 1, p. 35-43, maio. 2000.

LUSTOSA, Cesar Augusto. Milton Santos e o método de pesquisa em geografia. Tempo Técnica - Território. Brasília: UNB/DEGEO, V. 2, Nº.1, p. 49-59, 2011. Disponível em http://inseer.ibict.br/ciga/index.php/ciga.

MARTINELI, Marcello. Cartografia Temática: caderno de mapas. São Paulo: EDUSP, 2003.

Os mapas da Geografia. Congresso Brasileiro de Cartografia. São Paulo, 2003b. 
A cartografia do meio ambiente: a cartografia de tudo? In: Mesa Redonda: Cartografia do Meio Ambiente, $1^{\circ}$ Encontro Nacional de Geógrafos, AGB, Recife, 1996.

A representação cartográfica do mundo e dos lugares. In: O novo mapa do mundo: problemas geográficos de um mundo novo. Santos, M. (org.). Editora Anablume/Hucitec. $4^{\mathrm{a}}$ edição. São Paulo. 2002. p. 321-323.

As representações gráficas da Geografia: os mapas temáticos. Tese (livre-docência). USP-SP. São Paulo: FFLCH, 1999.

- Cartografia ambiental: uma cartografia diferente? Revista do Departamento de Geografia. USP, São Paulo. n. 7, 1994, p. 61-80.

. Curso de Cartografia Temática. São Paulo, Editora Contexto, 1991.

. Mapas da Geografia e cartografia temática. São Paulo: Contexto, 2003c.

. A imagem figurativa e a imagem cartográfica do turismo. In: FARIA, Ivani F. (Coord.) Turismo: lazer e políticas de desenvolvimento local. Manaus: EDUA, 2001b, p. 159-173.

. Cartografia do turismo e imaginário. In: RODRIGUES, Adyr B. (Org.). Turismo rural: práticas e perspectivas. São Paulo: Contexto, 2001, p. 151-170 (Col. Turismo Contexto).

MARTINELLI, Marcello; Pedrotti, M. A Cartografia das unidades de paisagem: questões metodológicas. Revista do Departamento de Geografia. USP, São Paulo, n. 14, 2001, p. 3946.

MATURANA, Humberto. A ontologia da realidade. Belo Horizonte: Ed. UFMG, 1997.

MERLEAU-PONTY, Maurice. Fenomenologia da percepção. Tradução Carlos Alberto de Moura. $2^{a}$ ed. São Paulo: Martins Fontes, 1999.

MOLINA, Fabio S. Turismo e produção do espaço - o caso de Jericaquara - CE. Dissertação (Mestrado). Programa de Pós-Graduação em Geografia Humana. Faculdade de Filosofia, Letra e Ciências Humanas/USP. São Paulo:USP, 2007. 
MORAES, Antonio Carlos R. de. Geografia, pequena história crítica. 12a ed. São Paulo: Hucitec, 1993.

MORAES, Antonio Carlos R.; COSTA, Wanderley Messias da. Geografia Crítica: a Valorização do espaço. $2^{a}$ ed. São Paulo: Hucitec, 1987.

OLIVEIRA, C. de. Dicionário cartográfico. $3^{\text {a }}$ ed. Rio de Janeiro: FIBGE, 1987.

OMT. Organização Mundial do Turismo. World Tourism Organization (UNWTO). Word tourism barometer. Volume 11 , January, 2013. Disponível em http://www.unwto.org/facts.

OMT. Organização Mundial do Turismo. World Tourism Organization (UNWTO). Tourism Highlights, 2012 Edition. Disponível em http://mkt.unwto.org/en/barometer.

PEREIRA, Henrique dos S. Iniciativas de co-gestão dos recursos naturais da várzea, Estado do Amazonas. Manaus: IBAMA/Pró-várzea, 2004.

PEREIRA, Simone Rocha; ROBLES, Léo Tadeu. Cruzeiros Marítimos: O Turismo de Viagem e o Porto de Santos. Anais do XIII Seminário em Administração - SEMES. São Paulo:FEA/USP, 9 e 10 de setembro de 2010. Disponível em http://www.ead.fea.usp.br/semead/13semead/. Acesso junho/2011.

PORRO, Antonio. O povo das águas: ensaios de etno-história amazônica. Petrópolis: Vozes; São Paulo: Edusp, 1995.

QUAINI. Massimo. Marxismo e Geografia. Tradução Liliana L. Fernandes. São Paulo: Paz e Terra, 1979.

QUEIROZ FILHO, Alfredo P.; MARTINELLI, Marcello. Cartografia de análise e de síntese na Geografia. Boletim Paulista de Geografia. São Paulo, nº 87, 2007, p. 7 - 43.

QUEIROZ, Denise Regina Elias. Cartografia Temática: evolução e caminhos de pesquisa Boletim de Geografia. Ano 25, vol.1, 2007, p. 137-150.

RAFFESTIN, Claude. Por uma Geografia do Poder. São Paulo: Ática,1993

REIS, Arthur Cézar F.. A origem de Parintins. Manaus: Governo do Estado do Amazonas, 1967, p. $1-57$ 
ROSS, Jurandyr L. S.(Org.) Geografia do Brasil. $6^{\text {a }}$ ed. São Paulo: EDUSP, 2005.

SALATI, Enéas. O Clima atual depende da floresta. In: SALATI, Enéas; SCHUBART, H.O.R.; WOLFGAN, J.; OLIVEIRA, A.E. . Amazônia: desenvolvimento, integração e ecologia. São Paulo: Brasiliense, 1983. p. 45-100.

SALATI, Enéas; SCHUBART, H.O.R.; WOLFGAN, J.; OLIVEIRA, A.E. . Amazônia: desenvolvimento, integração e ecologia. São Paulo: Brasiliense, 1983.

SANTOS, Milton. A natureza do espaço: técnica e tempo. Razão e Emoção $4^{\mathrm{a}}$ ed., $1^{\mathrm{a}}$ reimp. São Paulo: EDUSP, 2004 (Col. Milton Santos).

. Espaço e método. $4^{\mathrm{a}}$ ed. São Paulo: Nobel, 1997 (Coleção Espaços).

Espaço e sociedade. Petrópolis - RJ: Vozes, 1979.

Metamorfoses do espaço habitado, 6a ed. São Paulo: EDUSP, 2008 (Col. Milton Santos).

- Por uma geografia nova: da crítica da geografia a uma geografia crítica. São Paulo: EDUSP, 2002.

Por uma outra globalização: do pensamento único à consciência universal. $16^{\mathrm{a}}$ ed. Rio de Janeiro/São Paulo: Record, 2004b.

SAUNIER, Tonzinho. Parintins: memórias dos acontecimentos históricos. Manaus: Valer, 2003.

SDS. Secretaria de Estado do Meio Ambiente e Desenvolvimento Sustentável. Plano de Proteção: Área de Proteção Ambiental Nhamundá. Manaus, 2008.

SILVA, Armando Corrêa da. Fenomenologia e Geografia. Orientação. São Paulo: Instituto de Geografia-Departamento de Geografia/USP, nº 7, p. 53-56, 1986.

SILVA, Marilene Corrêa da. O Paiz do Amazonas. Manaus: Valer/Governo do estado do Amazonas/Uninorte, 2004. 
SIOLI, H. Amazônia: fundamentos de ecologia da maior região de florestas tropicais. Petrópolis, Vozes, 1985.

_. The Amazon and its main affluents: Hydrography, morphology of the river courses; and river types. In: SIOLI, H. (Ed.). The Amazon. Limnology and Landscape Ecology of a might Tropical River and its Basin. Dordrecht: Dr. W. JUNK Publishers, 1984, p. 127 165.

SOARES, Lúcio de Castro. Hidrografia. IN.: IBGE. Instituto Brasileiro de Geografia e Estatística. Geografia do Brasil. Região Norte. Vol. 3. Rio de Janeiro: IBGE, 1991, p. 73 121.

SOJA, E. W. Geografias pós-modernas: a reafirmação do espaço na teoria social. Rio de Janeiro: Jorge Zahar, 1993.

SOUZA, Celso Gutemberg. Solos. IN.: IBGE. Instituto Brasileiro de Geografia e Estatística. Geografia do Brasil. Região Norte. Vol. 3. Rio de Janeiro: IBGE, 1991, p. 123-136.

TUAN, Yi-fu. Paisagens do medo. Tradução Lívia de Oliveira. São Paulo: UNESP, 2005.

Espaço e lugar: a perspectiva da experiência. Tradução Lívia de Oliveira. São Paulo: DIFEL, 1983

Topofilia: um estudo da percepção, atitudes e valores do meio ambiente. São Paulo: Rio de Janeiro: DIFEL, 1980.

URRY, John. O olhar do turista, lazer e viagens nas sociedades contemporâneas. $2^{\mathrm{a}}$ ed. São Paulo: SESC/Studio Nobel, 1996 (tradução de Carlos Eugenio M. de Moura).

VALENTE, Isabel Farias; AZEVEDO FILHO, J. D. M. Levantamento das potencialidades turísticas na região do Paraná do Espírito Santo, APA Nhamundá, Amazonas. Marupiara, Ano 4, No. 5, p.88 - 104, jan-jun/2011.

VALENTIN, Andreas. Contrários: a celebração da rivalidade dos Bois-Bumbás de Parintins. Manaus: Valer, 2005. 
XAVIER, Herbe. A percepção geográfica do turismo. São Paulo: Aleph, 2007 (série Turismo).

WOOD, Robert E. Caribbean cruise tourism: globalization at sea. Annals of Tourism Research, Vol. 27, N. 2, pp. 345-370, 2000. Disponível em: http:// www.elsevier.com/locate/atoures. Acesso em 20/05/2012.

ZACARIAS, Andrea A; MARTINELLI, Marcello; CUNHA, Cenira Maria L.; PIROLLI, Edson Luiz. A Cartografia de Síntese no planejamento e gestão ambiental. Anais... XIII Simpósio Brasileiro de Geografia Física Aplicada (Comunicação Coordenada). Viçosa: UFV 06 a 10/07/2009. 
ANEXOS 


\title{
Anexo 1 - Questionário 1
}

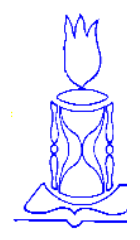

\author{
Universidade de São Paulo \\ Faculdade de Filosofia, Letras e Ciências Humanas \\ Universidade do Estado do Amazonas \\ Programa de Pós-Graduação em Geografia Humana \\ (Doutorado Interinstitucional - USP/UEA)
}

FFLCH

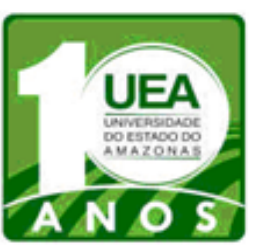

Nome (opcional):

É de livre e espontânea vontade participar do projeto de pesquisa: "A PRODUÇÃO E A PERCEPÇÃO DO TURISMO EM PARINTINS, AMAZONAS”. Sua colaboração autoriza o uso dos dados somente para fins do presente projeto de pesquisa e guardará sempre sigilo absoluto sobre a sua pessoa.

\section{DADOS PESSOAIS}
Parintins, .$/ 2012$. ...

1.1. Sexo ( ) Masc ( ) Fem

1.2. Idade: ............... anos

1.3. Qual sua escolariadade ?:

( ) Primário/ $1^{\mathrm{a}}$ a $4^{\mathrm{a}}$ Séries

( ) Secundário - Ensino Médio Incompleto

( ) Superior Incompleto

\subsection{Qual a sua Renda Média?}

( ) Até 1 Salário Minimo $(\mathrm{R} \$ 545,00)$

( ) entre 2 e 5 SM

2. SOBRE A VISITAÇÃO (TURISMO):

2.1. Qual seu local de Origem? (de onde veio?):

( ) Manaus

( ) Belém-PA

( ) Santarém-PA

( ) Outros:

2.2. È nascido ou residiu em Parintins? ....( ) SIM （） NÃO

2.3. Quais os motivos que o trouxeram a Parintins?

( ) Festival Folclórico de Parintins ( ) Visita à Família

( ) Ecoturismo: natureza/floresta/flora/fauna ( ) Outros:

2.4. Onde vai se hospedar?

( ) Hotel ou pousada

( ) Casa de parentes/amigos

( ) Casa ou suíte alugada

( ) Outros

\subsection{Lugares a serem visitados durante a estadia.}

( ) Centro/Visita aos pontos turísticos

( ) Bumbódromo/Festival e arredores

( ) Vila Amazônia

( ) Outros

2.6. Quais as atividades a serem desenvolvidas na cidade?:

( ) Passeio de carro/ triciclo/ônibus

( ) Pesca amadora

( ) Outras:

( ) Passeio de barco

( ) Festival Folclórico

2.7. Vem sempre a Parintins de avião?

( ) Sempre

( ) Na maioria vezes

( ) Outros
( ) É a $1^{\mathrm{a}}$ vez

( ) De barco e de avião 


\section{Anexo 2 - Questionário 2}

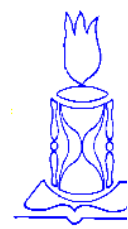

Universidade de São Paulo

Faculdade de Filosofia, Letras e Ciências Humanas

Universidade do Estado do Amazonas

Programa de Pós-Graduação em Geografia Humana

FFLCH

Nome (opcional):

É de livre e espontânea vontade participar do projeto de pesquisa: "A CONSTRUÇÃO E A PERCEPÇ̃̃O DO ESPAÇO TURISTICO EM PARINTINS-AMAZONAS”. Sua colaboração autoriza o uso dos dados somente para fins do presente projeto de pesquisa e guardará sempre sigilo absoluto sobre a sua pessoa. (local). /......../2012.

\section{Quadro A - Identificação do Turista}

1) Sexo: ( ) Masc. ( ) Fem.

2) Idade: anos

3) Estado Civil: ( ) Solt. ( ) Casado ( ) Viúvo ( ) Divorc. ( ) Outros

4) Profissão :

\section{Quadro B - Origem do Turista / Residência Permanente}

5) Cidade de origem: Estado: País:

6) Meio de Transporte para Viajar à Parintins: ( ) Navio/Barco ( ) Lancha a jato ( ) Avião ( ) Avião e Barco ( ) Ônibus e Barco ( ) Outros

Quadro C - Nível de Renda do Turista (Salário Mínimo = $\mathbf{R} \$ 622,00$ )

7) Renda Individual:

Até 2 SM ( ) De 2 a 5 SM ( ) De 5 a 10 SM ( ) Mais de 10 SM ( )

8) Renda Familiar (aproximado):

Até 5 SM ( ) De 5 a 10 SM ( ) De 10 a 20 SM ( ) Mais de 20 SM ( )

Quadro D - Gastos (aproximados) do Turista na viagem ao Festival de Parintins

9) Transporte: $R \$$

10) Hospedagem $R \$$

11) Alimentação $R \$$

12) Compras diversas $R \$$

13) Lazer e Recreação $R \$$

14) Quantas pessoas incluídas neste gasto?

( ) Uma ( ) Duas ( ) Três ( ) Quatro ( ) Cinco ( ) Seis ( ) Mais de 6

\section{Quadro E - Hábitos de Viagem do Turista}

15) Número de vezes que visita Parintins no período do Festival Folclórico

( ) É a 1a Vez ( ) Duas ( ) Três ( ) Quatro ( ) Cinco ( ) Seis ( ) Sete ( ) Oito ( ) Mais de 8 
16) Tempo de permanência em Parintins

( ) Um dia ( ) 2 dias ( ) De 3 a 7 dias ( ) De 8 a 14 dias

( ) De 15 a 21 dias ( ) De 22 a 30 dias ( ) Mais de 30 dias

17) Duração da Viagem Total (caso envolva outros municípios):

( ) Um dia ( ) 2 dias ( ) De 3 a 7 dias ( ) De 8 a 14 dias

( ) De 15 a 21 dias ( ) De 22 a 30 dias ( ) Mais de 30 dias

18) Viagem: ( ) Individual ( ) Grupos - quantos:

( ) Família - quantos:

19) Utilizou agência / operadora de viagens (ou outros vendedores de pacotes de viagem): ( ) Sim ( ) Não

20) Meio de Hospedagem utilizado:

( ) Hotel / Pousada

( ) Casa de amigos / parentes

( ) Casa própria / alugada

( ) Barco / navio

( ) Acampamento

( ) Outros

\section{Quadro F - Motivação da Viagem}

21) Qual(is) o(s) principal(is) motivo(s) da viagem ?

( ) Festival Folclórico de Parintins

( ) Conhecer a região

( ) Visitar/rever amigos e/ou parentes

( ) Trabalho ou negócios

( ) Outros

\section{Quadro G - Indução da Viagem}

22) Qual veículo de propaganda / comunicação induziu sua visita a Parintins / Festival Folclórico?

( ) Folhetos / Folders

( ) Revistas - qual :

( ) brnais (Caderno de Turismo) - qual :

( ) Rádio / TV / Filmes

( ) Publicações - qual :

( ) Amigos / Parentes

( ) Agências de viagens

( ) Feiras / Eventos

( ) Não se aplica

\section{Quadro H - Avaliação da Viagem}

23) Como você avalia sua viagem em relação à (aos):

Meio de transporte: ( ) ótimo ( ) satisfatória ( ) regular ( ) insatisfatório ( ) ruim Hospedagem:......... ( ) ótimo ( ) satisfatória ( ) regular ( ) insatisfatório ( ) ruim

Alimentação:............ ( ) ótimo ( ) satisfatório ( ) regular ( ) insatisfatório ( ) ruim Preços:................... ( ) ótimo ( ) satisfatória ( ) regular ( ) insatisfatório ( ) ruim Aquisição de ingressos/acesso ao Bumbódromo: ( ) ótimo ( ) satisfatória ( ) regular ( ) insatisfatório ( ) ruim

Atividade noturna: ...( ) ótimo ( ) satisfatória ( ) regular ( ) insatisfatório ( ) ruim Atrativos Naturais:... ( ) ótimo ( ) satisfatória ( ) regular ( ) insatisfatório ( ) ruim Atrativos Culturais:... ( ) ótimo ( ) satisfatória ( ) regular ( ) insatisfatório ( ) ruim Atendimento ao turista: ( ) ótimo ( ) satisfatória ( ) regular ( ) insatisfatório ( ) ruim Guias / Monitores: .... ) ótimo ( ) satisfatória ( ) regular ( ) insatisfatório ( ) ruim Avaliação geral da sua viagem nesta região: ( ) ótimo ( ) bom ( ) regular ( ) insatisfatório ( ) ruim 
24) Sobre os lugares turísticos fora da cidade que você conhece ou visitou:

( ) Vila Amazônia

( ) Zé Açu

( ) Boca da Valéria

( ) Brasília

( ) APA Nhamundá

( ) Macuricanã

( ) Limão

( ) Outros:

( ) Não conheço nenhum lugar.

25) Sobre a infraestrutura e outros serviços da cidade:

( ) Serviço de táxi ( ) ótimo ( ) satisfatória ( ) regular ( ) insatisfatório ( ) ruim

( ) Serviço de Mototaxi ( ) ótimo ( ) satisfatória ( ) regular ( ) insatisfatório ( ) ruim

( ) Serviço de Triciclos ( ) ótimo ( ) satisfatória ( ) regular ( ) insatisfatório ( ) ruim

( ) Passeio fluvial (de barco).... ( ) ótimo ( ) satisfatória ( ) regular ( ) insatisfatório ( ) ruim

( ) Limpeza pública .................( ) ótimo ( ) satisfatória ( ) regular ( ) insatisfatório ( ) ruim

( ) Segurança pública ................( ) ótimo ( ) satisfatória ( ) regular ( ) insatisfatório ( ) ruim

( ) Sinalização/Segurança no Trânsito ( ) ótimo ( ) satisfatória ( ) regular ( ) insatisfatório ( ) ruim

( ) Serviço de Internet .............. ( ) ótimo ( ) satisfatória ( ) regular ( ) insatisfatório ( ) ruim

( ) Serviços de telefonia ........... ( ) ótimo ( ) satisfatória ( ) regular ( ) insatisfatório ( ) ruim

( ) Atendimento médico-hospitalar ( ) ótimo ( ) satisfatória ( ) regular ( ) insatisfatório ( ) ruim

( ) Viu a sinalização urbana ...... ( ) ótimo ( ) satisfatória ( ) regular ( ) insatisfatório ( ) ruim

26) De acordo com essa experiência, você retornaria a Parintins? ( ) Sim ( ) Não

27) Que melhorias você gostaria de encontrar em uma próxima visita: (pode escrever a vontade)

28) Críticas ou sugestão para melhorar o turismo em Parintins:

29) De sua opinião sobre a importância do Festival de Parintins para o turismo no Amazonas/Brasil.

ENVIEPARA O E-MAIL: jdazevedo@uea.edu.br com cópia para jdazevedogeo@hotmail.com 
Anexo 3 - Lei de Parintins Cidade do Folclore Amazonense 


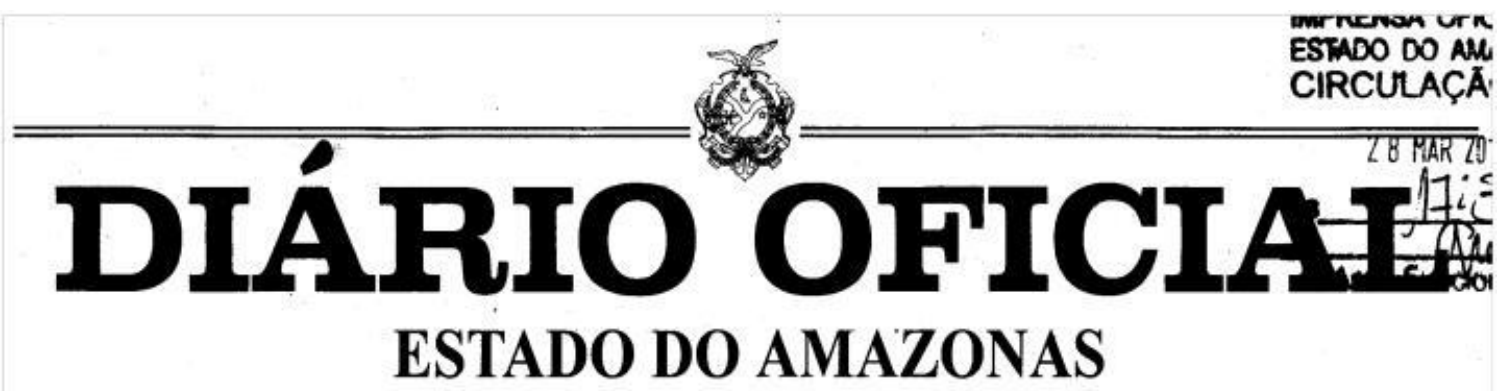

Manaus, terça-feira, 27 de março de 2012

Número 32.284 ANO CXVII

\section{PODER EXECUTIVO}

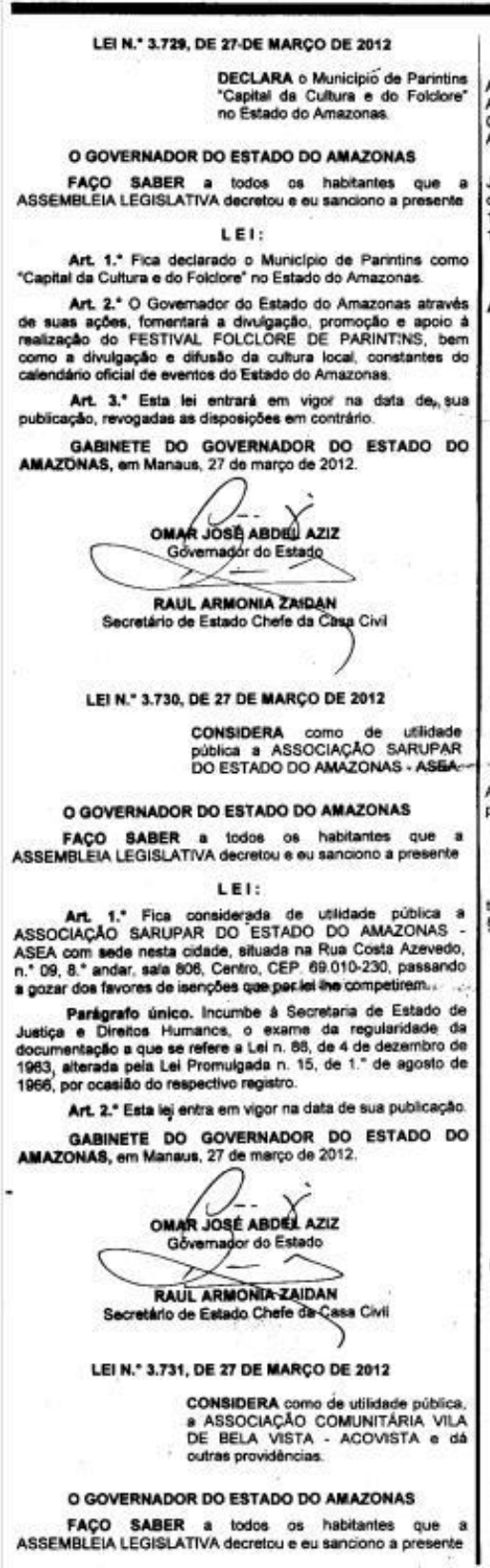

LEI

Art 10" Fica considerada como de unildade púbica: a
DISTA ASSOCIACAO COMUNITARIA Benjamin Roberto, n 701 A Comunidado

Parkgrafo único. Incumbe a Secretaria de Estado de Justiça e Direilos Humanos, o exame da regulandade da documentacas a que se retere a Lexin. 86 , de 4 de dezembro de 1963, anerada pela Lei Promulgada $n$. 15, de $1, "$ de agosto de

Art. 2." Esta lei entra ema vigor na data de sua pubicaça GABINETE DO GOVERNADOR DO ESTADO DO AMAZZNAS, en Manaus, 27 de marło de 2012.

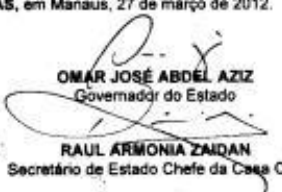

Socreatirio de Estado Chete da Coga Civ

LEI N.' 3.732, DE 27 OE MARÇO DE 2012 ALTERA, na forma que especifica.

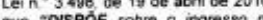
que outras providencias.". of outras providencis

O GOVERNADOR DO ESTADO DO AMAZONAS

FACO SABER a todos os habiantes que. ASSEMBLEIA LEGISLATIVA decretou e en sanciono LEI:

An. 1." (VEetado

Art. 2: 0 artigo 22 passa a voorar com a GS2." $3^{\circ}$. com as sepuntes redaçes Art 22.

51. A creario da Administraçäo Matrer de PMAM

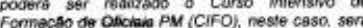
exigide. que o candidato lentha concivido o curs. de graduagito supericr em Diveña. em instituigà

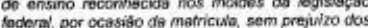
foderal, por ocastis

52. 0 regunte 52. quadros da Caporacso 52:- A comprovacto das requistos istados nesto curso de tormariso especifico. dos paragrafos unicos, com as seguintes redaçbes "Art. 25.

Pardigrafo énica. 0 requiseto di idade previsto

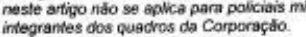

Art 29

Paragrafo única. A comprovaçdo dos requistos

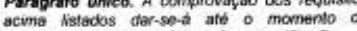
concilusso do curso de formaçato especinica"

Art 4. O Peder Executivo promovers, por meis da Casa Civil, com acorlio da Polica Mistar do Estado do ae n- 3.498, de 19 de abril de 2010, com texto consolidedo tace das disposiçes desta Lei.
Art. 5." Revogadas as disposipbes em contercic, este di entra em vigor na data de sua pubticaçác, retrowgindo seus

GABINETE DO GOVERNADOR DO ESTADO DO AMAZONAS, em Manaus, 27 de março de 2012

$$
\text { Secretbrio de Estado Chefe dr Casa Cinil }
$$

DECRETO N." 32 220, DE 27 DE MARÇO DE 2012

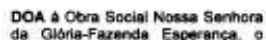

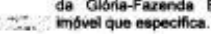

- governador do estado do amazonas mo

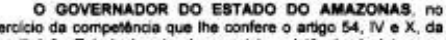

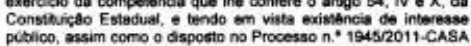
Púbilico, assim como o disposto no Processo n." 19452011-CASA

DECRETA :

Art 1. Fica at Otra Social Nossa Senhora da Greris Fazentar

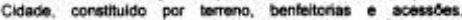
registrado no $3^{\circ}$ Cantorio de Ragistso de imoveis da Camare de

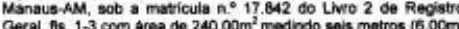
de frente, por auseres metros de fundos $(40.00 \mathrm{~m}) \mathrm{com}$ a

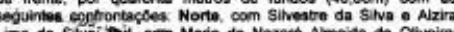

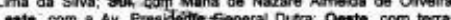

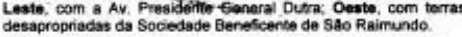

Ant. $2^{\circ} \mathrm{O}$ inovel descrito no artigo anterior, doado a Obra Socisa Ant. Noss Senhera da Glória - Fazental Esperanca. por

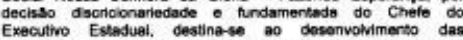

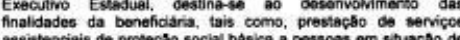

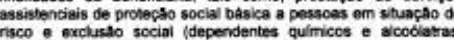
nscoo ex exchusto social (dependentes quimicos e accoolatras.

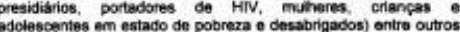
fins previstos en sey Estato pociel

Art. $3^{\circ}$ Fica a Prociradoria Geral do Estado inoumbide

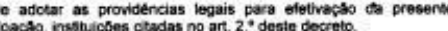

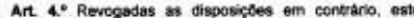
eto entra am vigor na data de sua publicaça. GABINETE DO gOVERnADOR DO ESTADO DO AMAZONAS, em Manaus, 27 do març de 2012.

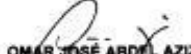 \\ OMOR JOSE ABOC AZIZ} Governagor do Estado

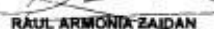
Secretario de Estado Chefe da Cosea Cirl

\section{AVIso}

Na ediçấo de hoje, por falto exclusiva de matérias, náo será publicado o caderno relacionado ao

PODER LEGISLATIVO 
NAVIOS 2010/2011

\begin{tabular}{|c|c|c|}
\hline Navio & Roteiro & Dias/data saída \\
\hline \multirow[t]{2}{*}{ Princess Cruises, Pacific Princess } & $\begin{array}{l}\text { - Starting in Ft. Lauderdale with stops } \\
\text { in St. Thomas, St. Lucia, } \\
\text { Scarborough, Devil's Island, Santarem, } \\
\text { Boca da Valeria, Parintins, Manaus }\end{array}$ & 14 Days/Dec 22 \\
\hline & $\begin{array}{l}\text { Ft Lauderdale, stops include, St } \\
\text { Thomas, St Lusica, } \\
\text { Scarborough, Devil's Island, Santarem, } \\
\text { Boca da Valeria, Parintins, Manaus, } \\
\text { Parintins, Boca de Valeria, Santarem, } \\
\text { Devil's Island, Scarborough, St Lusica, } \\
\text { St Maarten, Ft Lauderdale }\end{array}$ & 28 Days/Dec 22 \\
\hline \multirow[t]{3}{*}{ Seabourn, Seabourn Odyssey } & $\begin{array}{l}\text { Starting in Fort Lauderdale with stops } \\
\text { in Cruising the Florida } \\
\text { Strait, Cruising the Caribbean Sea, San } \\
\text { Blas Islands, Transiting the Panama } \\
\text { Canal, Fuerte Amador, Cruising the } \\
\text { Pacific Ocean, Guayaquil, Salaverry, } \\
\text { Callao, Arica, Iquique, Valparaiso, } \\
\text { Puerto Montt, Cruising the Corcovado } \\
\text { Gulf, Puerto Chacabuco, Cruising the } \\
\text { Chilean Fjords, Punta Arenas, Cruising } \\
\text { Cape Horn, Ushuaia, Cruising the } \\
\text { Atlantic Ocean, Port Stanley, cruising } \\
\text { the Falkland Islands, cruising the South } \\
\text { Atlantic Oc, Puerto Madryn, Buenos } \\
\text { Aires, Montevideo, Punta del Este, } \\
\text { Parati, Rio de Janeiro, Salvador De } \\
\text { Bahia, Natal, Cruising the Amazon } \\
\text { River, Santarem, Anavilhanas, Manaus }\end{array}$ & 58 Nights/ Jan 4 \\
\hline & $\begin{array}{l}\text { Starting in Fort Lauderdale with stops } \\
\text { in Cruising the Florida Strait, Cruising } \\
\text { the Caribbean Sea, San Blas Islands, } \\
\text { Transiting the Panama Canal, Fuerte } \\
\text { Amador, Cruising the Pacific Ocean, } \\
\text { Guayaquil, Salaverry, Callao, Arica, } \\
\text { Iquique, Valparaiso, Puerto Montt, } \\
\text { Cruising the Corcovado Gulf, Puerto } \\
\text { Chacabuco, Cruising the Chilean } \\
\text { Fjords, Punta Arenas, Cruising Cape } \\
\text { Horn, Ushuaia, Cruising the Atlantic } \\
\text { Ocean, Port Stanley, CRUISING THE } \\
\text { FALKLAND ISLANDS, CRUISING } \\
\text { THE SOUTH ATLANTIC OC, Puerto } \\
\text { Madryn, Buenos Aires, Montevideo, } \\
\text { Punta del Este, Parati, Rio de Janeiro, } \\
\text { Salvador De Bahia, Natal, Cruising the } \\
\text { Amazon River, Santarém, Anavilhanas, } \\
\text { Manaus, Parintins, Alter do Chao, } \\
\text { Devils Island, Bridgetown, Gustavia, } \\
\text { Jost van Dyke }\end{array}$ & 73 Nights/Jan 4 \\
\hline & $\begin{array}{l}\text { - Starting in Valparaiso with stops in } \\
\text { Cruising the Pacific Ocean, Puerto } \\
\text { Montt, Cruising the Corcovado Gulf, } \\
\text { Puerto Chacabuco, Cruising the } \\
\text { Chilean Fjords, Punta Arenas, Cruising } \\
\text { Cape Horn, Ushuaia, Cruising the } \\
\text { Atlantic Ocean, Port Stanley, }\end{array}$ & 39 Nights/Jan 23 \\
\hline
\end{tabular}




\begin{tabular}{|c|c|c|}
\hline & $\begin{array}{l}\text { CRUISING THE FALKLAND } \\
\text { ISLANDS, CRUISING THE SOUTH } \\
\text { ATLANTIC OC, Puerto Madryn, } \\
\text { Buenos Aires, } \\
\text { Montevideo, Punta del Este, Parati, Rio } \\
\text { de Janeiro, Salvador De Bahia, Natal, } \\
\text { Cruising the Amazon River, Santarém, } \\
\text { Anavilhanas, Manaus }\end{array}$ & \\
\hline & $\begin{array}{l}54 \text { Days - Starting in Valparaiso with } \\
\text { stops in Cruising the Pacific Ocean, } \\
\text { Puerto Montt, Cruising the Corcovado } \\
\text { Gulf, Puerto Chacabuco, Cruising the } \\
\text { Chilean Fjords, Punta Arenas, Cruising } \\
\text { Cape Horn, Ushuaia, Cruising the } \\
\text { Atlantic Ocean, Port Stanley, } \\
\text { CRUISING THE FALKLAND } \\
\text { ISLANDS, CRUISING THE SOUTH } \\
\text { ATLANTIC OC, Puerto Madryn, } \\
\text { Buenos Aires, Montevideo, Punta del } \\
\text { Este, Parati, Rio de Janeiro, Salvador } \\
\text { De Bahia, Natal, Cruising the Amazon } \\
\text { River, Santarém, Anavilhanas, Manaus, } \\
\text { Parintins, Alter do Chao, Devils Island, } \\
\text { Bridgetown, Cruising the Caribbean } \\
\text { Sea, Gustavia, Jost van Dyke, Fort } \\
\text { Lauderdale }\end{array}$ & 54 Nights/jan 23 \\
\hline & $\begin{array}{l}\text { - Starting in Buenos Aires with stops in } \\
\text { Montevideo, Punta del } \\
\text { Este, Cruising the Atlantic Ocean, } \\
\text { Parati, Rio de Janeiro, Salvador De } \\
\text { Bahia, Natal, Cruising the Amazon } \\
\text { River, Santarém, Anavilhanas, Manaus }\end{array}$ & 20 Days/ Feb 11 \\
\hline & $\begin{array}{l}\text { - Starting in Buenos Aires with stops in } \\
\text { Montevideo, Punta del } \\
\text { Este, Cruising the Atlantic Ocean, } \\
\text { Parati, Rio de Janeiro, Salvador De } \\
\text { Bahia, Natal, Cruising the Amazon } \\
\text { River, Santarém, Anavilhanas, Manaus, } \\
\text { Parintins, Alter do Chao, Devils Island, } \\
\text { Bridgetown, Cruising the Caribbean } \\
\text { Sea, Gustavia, Jost van Dyke, Fort } \\
\text { Lauderdale }\end{array}$ & 35 Days/ Feb 11 \\
\hline \multirow[t]{2}{*}{$\begin{array}{l}\text { Holland America (HAL), HAL } \\
\text { Prinsendam }\end{array}$} & $\begin{array}{l}\text { - Starting in Fort Lauderdale with stops } \\
\text { in Half Moon Cay, } \\
\text { Bridgetown, Devil's Island, MacApa, } \\
\text { Crossing the Equator, Santarem, Boca } \\
\text { da Valeria, Manaus, Parintins, Alter do } \\
\text { Chao, Belem, Fortaleza, Fernando de } \\
\text { Noronha, Recife, Salvador da Bahia, } \\
\text { Rio de Janeiro, Parati, Montevideo, } \\
\text { Buenos Aires }\end{array}$ & 33 Days/Jan 5 \\
\hline & $\begin{array}{l}\text { - Starting in Fort Lauderdale with stops } \\
\text { in Half Moon Cay, Bridgetown, Devil's } \\
\text { Island, MacApa, Crossing the Equator, } \\
\text { Santarem, Boca da Valeria, Manaus, } \\
\text { Parintins, Alter do Chao, Belem, } \\
\text { Fortaleza, Fernando de Noronh, } \\
\text { Recife, Salvador da Bahia, Rio de } \\
\text { Janeiro, Parati, Montevideo, Buenos }\end{array}$ & 66 Days/ Jan 5 \\
\hline
\end{tabular}




\begin{tabular}{|c|c|c|}
\hline & $\begin{array}{l}\text { Aires, Pt. Stanley, The Antarctic } \\
\text { Sound, South Shetland Islands, } \\
\text { Wilhelm Archipelago, Cape Horn \& } \\
\text { Drake Passage, Ushuaia, Punta Arenas, } \\
\text { Chilean Fjords, Puerto Montt, Isla } \\
\text { Robinson Crusoe, Valparaiso, General } \\
\text { San Martin, Callao, Manta, Fuerte } \\
\text { Amador, Enter Panama Canal Balboa, } \\
\text { Exit Panama Canal Cristobal, } \\
\text { Oranjestad }\end{array}$ & \\
\hline \multirow[t]{2}{*}{$\begin{array}{l}\text { Holland America }(\mathrm{HAL}), \mathrm{HAL} \\
\text { Veendam }\end{array}$} & $\begin{array}{l}\text { - Starting in Rio de Janeiro with stops } \\
\text { in Armacao dos Buzio, Abraao, Santos, } \\
\text { Montevideo, Buenos Aires, Punta del } \\
\text { Este, Paranagua, Ilhabela, Paraty, } \\
\text { Salvador, Recife, Fortaleza, Belem, } \\
\text { Macapa, Crossing the } \\
\text { Equator, Santarem, Boca da Valeria, } \\
\text { Manaus, Parintins, Alter do Chao, } \\
\text { Devil's Island, Bridgetown, Oranjestad, } \\
\text { Grand Turk, Half Moon Cay, Fort } \\
\text { Lauderdale }\end{array}$ & 42 Days/ Mar 4 \\
\hline & $\begin{array}{l}\text { - Starting in Rio de Janeiro with stops } \\
\text { in Salvador, Recife, Fortaleza, Belem, } \\
\text { Macapa, Crossing the Equator, } \\
\text { Santarem, Boca da Valeria, Manaus, } \\
\text { Parintins, Alter do Chao, Devil's } \\
\text { Island, Bridgetown, Oranjestad, Grand } \\
\text { Turk, Half Moon Cay, Fort Lauderdale }\end{array}$ & 28 Days/Mar 18 \\
\hline \multirow[t]{2}{*}{$\begin{array}{l}\text { Regent Seven Seas, Seven Seas } \\
\text { Mariner }\end{array}$} & $\begin{array}{l}\text { - Starting in Fort Lauderdale with stops } \\
\text { in Cruise the Caribbean Sea, } \\
\text { Willemstad, Oranjestad, Cartagena, } \\
\text { Transit the Panama Canal, Cruise the } \\
\text { Gulf of Panama, Manta, Guayaquil, } \\
\text { Cruise the Coast of Peru, Salaverry, } \\
\text { Callao, Pisco, Cruise the Pacific } \\
\text { Ocean, Coquimbo, Valparaiso, Puerto } \\
\text { Montt, Puerto Chacabuco, Laguna San } \\
\text { Rafael, Cruising the Chilean Fjords, } \\
\text { Punta Arenas, Ushuaia, Drake Passage, } \\
\text { Deception Island, Paradise Bay, Half } \\
\text { Moon Island, Cruise the South Atlantic } \\
\text { Ocean, Port Stanley, Puerto Madryn, } \\
\text { Cruise the Coast of Argentina, } \\
\text { Montevideo, Buenos Aires, Punta del } \\
\text { Este, Rio Grande, Cruise the Coast of } \\
\text { Brazil, Santos, Paraty, Ilha Grande, } \\
\text { Buzios, Rio de Janeiro, Salvador De } \\
\text { Bahia, Fortaleza, Macapa (Amazon } \\
\text { River), Alter Do Chao (Amazon } \\
\text { River), Boca da Valeria (Amazon } \\
\text { River), Manaus (Amazon River), } \\
\text { Parintins (Amazon River), Santarem } \\
\text { (Amazon River), Devil's Island, Cruise } \\
\text { the Atlantic Ocean, Bridgetown, St. } \\
\text { John's, Charlotte Amalie, Cross the } \\
\text { Tropic of Cancer }\end{array}$ & 71 Nights/Jan 11 \\
\hline & $\begin{array}{l}\text { - Starting in Rio de Janeiro with stops } \\
\text { in Cruise the Coast of Brazil, Salvador } \\
\text { De Bahia, Fortaleza, Macapa (Amazon } \\
\text { River), Alter Do Chao (Amazon }\end{array}$ & 21 Days/ Mar 2 \\
\hline
\end{tabular}




\begin{tabular}{|c|c|c|}
\hline & $\begin{array}{l}\text { River), Boca da Valeria (Amazon } \\
\text { River), Manaus (Amazon River), } \\
\text { Parintins (Amazon River), Santarem } \\
\text { (Amazon River), Cruise the Caribbean } \\
\text { Sea, Devil's Island, Cruise the Atlantic } \\
\text { Ocean, Bridgetown, St. John's, } \\
\text { Charlotte Amalie, Cross the Tropic of } \\
\text { Cancer, Fort Lauderdale }\end{array}$ & \\
\hline Compagnie du Ponant, Le Levant & $\begin{array}{l}\text { - Starting in Cayenne, with stops in } \\
\text { Macapa, Manaus and Belem }\end{array}$ & 14 Days/ Mar 14 \\
\hline Oceania Cruises, Oceania Regatta & $\begin{array}{l}\text { - Starting in Miami with stops in } \\
\text { Cruising the Atlantic Ocean, Gustavia, } \\
\text { Castries, Scarborough, Cruising the } \\
\text { Amazon River, Santarem, Boca da } \\
\text { Valeria, Manaus, Parintins, Devil's } \\
\text { Island, Bridgetown, Roseau, Virgin } \\
\text { Gorda, Cayo Levantado, Nassau }\end{array}$ & 24 Days/ Mar 19 \\
\hline \multirow[t]{2}{*}{ Hapag-Lloyd Cruises, MS Hanseatic } & $\begin{array}{l}\text { - Scheduled flight Frankfurt - Rio de } \\
\text { Janeiro, City tour, overnight stay with } \\
\text { breakfast, Scheduled flight to } \\
\text { Belem/Brazil, Daytime passage } \\
\text { through the Breves Channels, stops } \\
\text { include, Upstream on the lower } \\
\text { Amazon with Zodiac Langings, } \\
\text { Manaus/Brazil, Iquitos/Peru, charter } \\
\text { flight to Lima, overnight stay with } \\
\text { breakfast, City tour, scheduled flight } \\
\text { Lima - Frankfurt, Arrival in Frankfurt }\end{array}$ & 19 Days/ Apr 4 \\
\hline & $\begin{array}{l}\text { - Scheduled flight Frankfurt - Lima, } \\
\text { overnight stay with breakfast, Charter } \\
\text { flight to Iquitos, overnight stay on } \\
\text { board, stops include, Pevas/Peru, } \\
\text { Downstream on the upper River } \\
\text { Amazon with Zodiac landings, } \\
\text { Manaus/Brazil, Downstream on the } \\
\text { upper River Amazon with } \\
\text { Zodiac landings, Daytime passage } \\
\text { throught he Breves Channels, } \\
\text { Belem/Brazil, scheduled flight Belem - } \\
\text { Frankfurt, Arrival in Frankfurt }\end{array}$ & 15 Days/ Apr 20 \\
\hline
\end{tabular}

